\title{
PALM SAGO A Tropical Starch from Marginal Lands
}

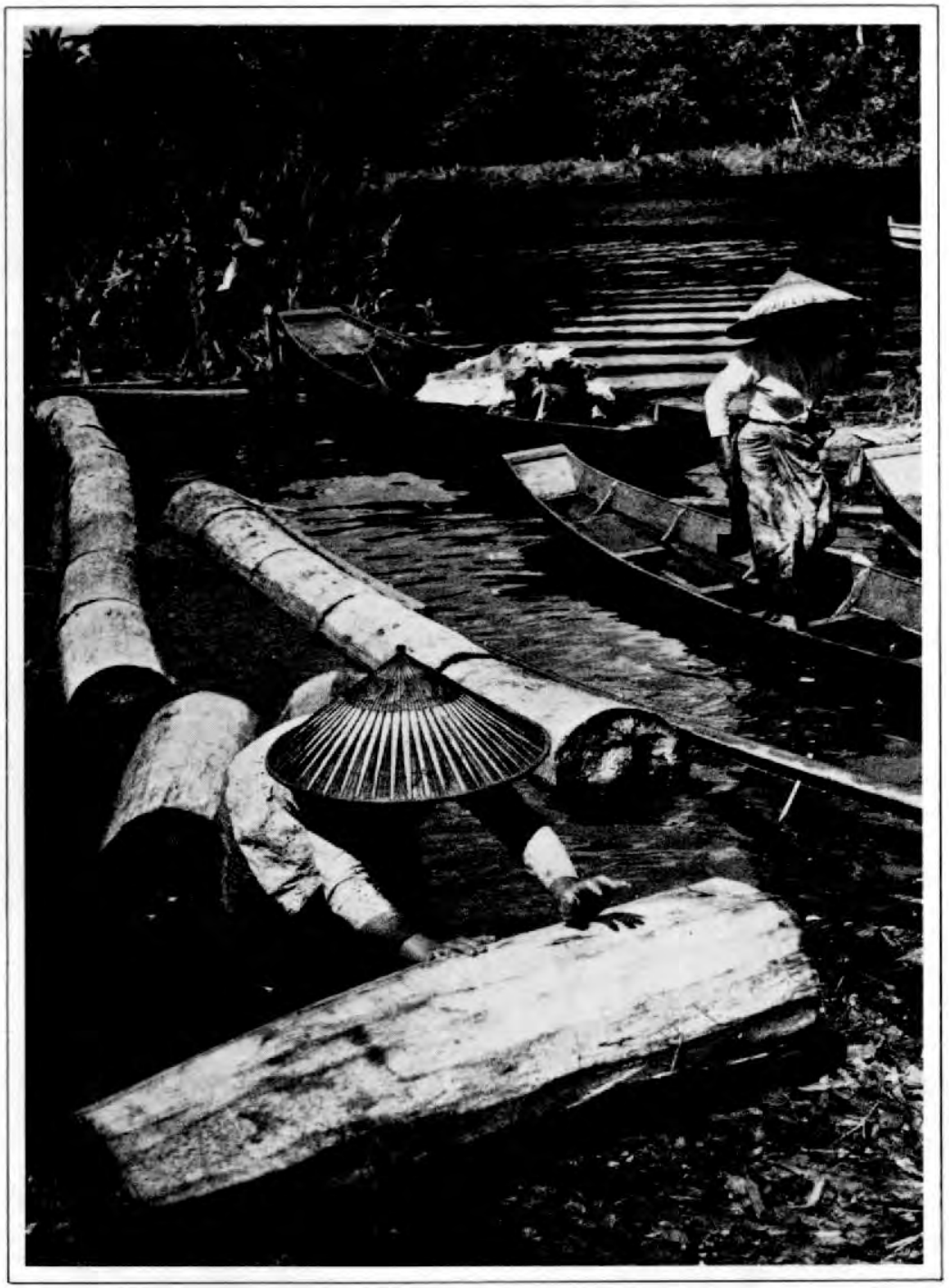

KENNETH RUDDLE DENNIS JOHNSON PATRICIA K. TOWNSEND JOHN D. REES 


\section{Farmers in the Forest}

\section{Economic Development and Marginal Agriculture in Northern Thailand}

edited by Peter Kunstadter, E. C. Chapman, and Sanga Sabhasri

Though concentrating chiefly on conditions in northern Thailand, this book is concerned with the increasingly complex problems of all tropical countries where rapid growth of rural population exerts heavy pressure on traditional farming systems and causes increasing competition for natural resources of these areas. The book brings together a wide range of studies by forest ecologists, soil scientists, anthropologists, and geographers, who describe the variety of swidden (slashand-burn cultivation) land-use systems and their effects on soil and forest. They point to conflicts between traditional land use and land tenure and the modern legal and administrative constraints within which these farming systems must operate; they describe the social and technological conditions that have contributed to the development of a marginal, stagnant econo$\mathrm{my}$ - which has serious ecological consequences. Several possible solutions are suggested to help solve these pressing human, environmental, and economic problems.

ANEAST WEST CENTER BOOK 五 ISBN 0-8248-0366-3

$1978, \$ 24.00$

\section{Agricultural Growth in} Japan, Taiwan,
Korea, and
the Philippines edited by Yuïro Hayami, Vernon W. Ruttan, and Herman M. Southworth

A major contribution to the historical study of agriculture in Asia, this pioneering work lays a solid foundation for future intercountry comparisons of agricultural productivity. Based on papers presented by leading authorities at a conference at the East-West Center in February 1973, this study examines the changes in the agricultural indices in Japan, Taiwan, Korea, and the Philippines and relates these changes to the agricultural policies of these four countries.

This book is being published cooperatively with the Asian Productivity Organization in Tokyo.

ANEAST-WEST CENTER BOOK

ISBN 0-8248-0391-4, cloth

ISBN 0-8248-0613-1, paper

1978, prices to be announced

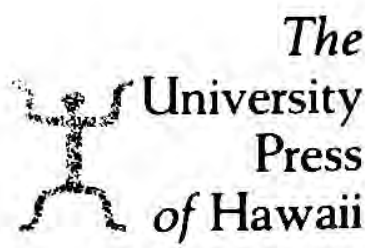

2840 Kolowalu Stre日 $†$ Honolulu, Hawail 96822 


\section{Palm Sago}


玉 THE EAST-WEST CENTER-officially known as the Center for Cultural and Technical Interchange Between East and West-is a national educational institution established in Hawaii by the U.S. Congress in 1960 to promote better relations and understanding between the United States and the nations of Asia and the Pacific through cooperative study, training, and research. The Center is administered by a public, nonprofit corporation whose international Board of Governors consists of distinguished scholars, business leaders, and public servants.

Each year more than 1,500 men and women from many nations and cultures participate in Center programs that seek cooperative solutions to problems of mutual consequence to East and West. Working with the Center's multidisciplinary and multicultural staff, participants include visiting scholars and researchers; leaders and professionals from the academic, government, and business communities; and graduate degree students, most of whom are enrolled at the University of Hawaii. For each Center participant from the United States, two participants are sought from the Asian and Pacific area.

Center programs are conducted by institutes addressing problems of communication, culture learning, environment and policy, population, and resource systems. A limited number of "open" grants are available to degree scholars and research fellows whose academic interests are not encompassed by institute programs.

The U.S. Congress provides basic funding for Center programs and a variety of awards to participants. Because of the cooperative nature of Center programs, financial support and cost-sharing are also provided by Asian and Pacific governments, regional agencies, private enterprise and foundations. The Center is on land adjacent to and provided by the University of Hawaii.

East-West Center Books are published by The University Press of Hawaii to further the Center's aims and programs. 


\section{Palm Sago}

\section{A Tropical Starch from Marginal Lands}

KENNETH RUDDLE

DENNIS JOHNSON

PATRICIA K. TOWNSEND

JOHN D. REES

₹ ANEAST-WEST CENTER BOOK from the East-West Technology and Development Institute

Published for the East-West Center by The University Press of Hawaii Honolulu 
Copyright (c) 1978 by East-West Center

All rights reserved. No part of this work may be reproduced or transmitted in any form or by any means, electronic or mechanical, including photocopying and recording, or by any information storage or retrieval system, without permission in writing from the publisher.

Manufactured in the United States of America

Library of Congress Cataloging in Publication Data

Main entry under title:

Palm sago.

Bibliography: p.

Includes index.

1. Sago. I. Ruddle, Kenneth.

TP416.S3P34 338,4'7'6642 77-28981

ISBN 0-8248-0577-1

Simultaneously published by Australian National University Press, Canberra, and for the East-West Center by The University Press of Hawaii, Honolulu.

The cover photograph is of Melanau women dismantling a Metroxylon palm log raft in preparation for extracting sago (photo courtesy of the Sarawak Museum). 
This book is respectfully dedicated to Professor Joseph E. Spencer, an eclectic geographer, on his retirement. 



\section{CONTENTS}

Figures ix

Tables $\quad x i$

Preface xiii

Acknowledgments $\quad \mathrm{xV}$

1. Introduction 1

2. Traditional Extraction and Preparation of Sago 11

3. Sago as Subsistence, Complementary, and Emergency Food 42

4. Sago in Myth and Ritual $\quad 70$

5. Modern Commercial Sago Production in Sabah, Brunei,

$\begin{array}{ll}\text { 6. International Trade } & 130\end{array}$

7. The Future Outlook for Sago Production 184

$\begin{array}{ll}\text { Notes } & 189\end{array}$

$\begin{array}{ll}\text { Bibliography } & 191\end{array}$

$\begin{array}{ll}\text { Index } & 203\end{array}$ 



\section{FIGURES}

1. Distribution of Old World palm genera. 6

2. Distribution of New World palm genera. 8

3. Warao man using adze to chop pith of Mauritia palm.

4. Warao women collecting chopped pith. 13

5. Warao women kneading pith to express starch. 14

6. Sanio-Hiowe woman chopping pith of Metroxylon palm. 17

7. Loosened Metroxylon pith ready for Sanio-Hiowe processing.

8. Sanio-Hiowe apparatus for sago processing. 21

9. Sanio-Hiowe woman kneading pith to express starch. 23

10. Melanau sago trampling platform. 24

11. Sanio-Hiowe sedimentation trough. 25

12. Melanau sedimentation vessel. 26

13. Sanio-Hiowe wrapping sago for storage. 28

14. Melanau pearl sago manufacture. 29-35

15. Insular Southeast Asian sago-producing groups. 46

16. Tasaday production, preparation, and use of Caryota sago.

17. Man-hours required to produce 1 million calories. 65

18. Metroxylon palms bordering rice fields in Sabah. 102

19. Metroxylon palms in swampy depressions between rubber plantations, Sabah.

20. Nonutilized Metroxylon palm, Sabah. 104

21. Bisaya sago palm stump, pith scooped out for chicken feed.

22. Bisaya use of palm leaf midribs as skids. 
23. Bisaya sago production.

$108-112$

24. Marketing sago, Beaufort, Sabah.

113

25. Weighing and bagging sago, Beaufort, Sabah.

114

26. Logs stored in the River Oya, awaiting processing, Sarawak. 


\section{TABLES}

1. Principal genera exploited for stem starch.

2. Some ethnic groups producing sago.

3. Estimates of sago yield by genus.

$62-63$

4. West Malaysia: Area under sago palms, 1960.

5. Sabah: Estimated production of sago, 1970 .

6. Sabah: Size of farms growing sago, $\mathbf{1 9 7 0 .}$

7. The Bisaya sago process.

8. Brunei: Estimated production of sago, 1937-1970.

9. Commercial sago mill operations, Dalat, Sarawak.

10. Production process in a modern industrial sago refinery, Sibu, Sarawak.

11. People's Republic of China: Exports of sago and tapioca, 1964-1970.

12. Thailand: Exports of sago flour and pearl sago, 1955-1969.

13. Indonesia: Exports of sago, 1879-1974.

15. Indonesia: Direction of import trade of sago, 1879-1940.

16. Direction of import trade in sago flour and meal, 1960-1974.

17. Sarawak: Imports of sago flour, 1870-1973. 1960-1974.

19. Sarawak: Exports of sago flour, 1870-1973. 
21. Singapore: Exports of sago flour and pearl sago, 1923-1974.

22. Singapore: Direction of export trade in sago flour and meal, 1957-1974.

23. Direction of import trade in sago refuse, 1960-1974.

24. Direction of export trade in sago refuse, 1960-1974.

25. Sarawak: Exports of sago pith, 1870-1924.

26. Direction of import trade in sago pith, 1960-1974.

27. Direction of export trade in sago pith, 1960-1974.

$170-171$

28. Singapore: Direction of export trade in pearl sago, 1957-1974.

172-175

29. Direction of export trade in pearl sago, 1960-1974.

$176-177$

30. Direction of import trade in pearl sago, 1960-1974.

178-181

31. Sarawak: Exports of pearl sago, 1870-1973.

32. Sarawak: Imports of pearl sago, 1873-1973. 


\section{PREFACE}

The authors, three geographers and an anthropologist, whose interests in ethnobotany, human ecology, and the geography of economic plants overlap to a considerable extent, have long been concerned with rural peoples in tropical countries, and with their special problems of making a living. In particular we share an interest in ancient food plants, plant products, cultivation technologies, and decision-making strategies for the use of renewable biotic resources. We believe that time-honored systems of resource use merit closer examination than they have hitherto received, and that some such systems may gain renewed importance in helping to solve the food and development problems of the humid tropics.

Sago, starch extracted from the stems of several palm taxa, is a pantropic source of carbohydrates which, surprisingly, has generally received only scattered attention in the literature. Despite its local importance in many widely scattered parts of the world, and its use by many diverse culture groups, there are no adequate worldwide surveys of sago. Given the fundamental economic importance of sago in many developing areas, particularly in Sarawak and Indonesia, we consider that this study is particularly timely. 
. 


\section{ACKNOWLEDGMENTS}

It is difficult, if not impossible, to acknowledge all the considerable help received during the preparation of this study. We are particularly grateful to the Departments of Agriculture in Sarawak and Sabah.

For invaluable assistance and warm hospitality extended to Kenneth Ruddle in the field we are indebted to Balwant Gill, Francis Ariffin, and O. K. K. Asnih (Department of Agriculture, Sabah), and to Joseph Kong, Andrew Tan, Wong Leong Do, and Stephen Sani (Department of Agriculture, Sarawak). In Sarawak we also benefited greatly from the information and advice provided by Wee Ai Chin (Department of Agriculture), Chua Chong Hui (Sarawak Chemical Industries), and Bartholomew Sulee (St. Bernard's School, Dalat). For their assistance in assessing the situation in Thailand we are grateful to Dr. Oradee Saharachavin and Professor V. Suwanakitti of Chulalongkorn University, Bangkok, and in Indonesia, to Dr. John Dransfield of Kew Gardens. The vicissitudes of the sago industry in Singapore were more easily traced with the generous help of Lee Chwee Cheng, Librarian, Singapore International Chamber of Commerce, and S. K. Ang of the Hong Seng Sago Manufacturing Co. Loh Chee Yin, Archivist at the Sarawak Museum, facilitated the tracking down of important historical materials.

In addition, we would like to express our appreciation to many other people whose often considerable labors greatly enhanced 
this work; Omar Haji Serudin (Office of State Secretary, Brunei), Chong Choon Chiang (Department of Statistics, Sarawak), K. S. Yap (Department of Statistics, Republic of Singapore), Ng Suet Pin (Department of Statistics, West Malaysia), and Lo Wing Leung (Department of Census and Statistics, Hong Kong) for helping to compile statistical data. Martin Hatch of Cornell University kindly furnished us with the Indonesian statistics. But, despite all those expert resource persons, we alone are responsible for all errors of commission and omission.

For permission to reproduce photographs we acknowledge the kindness of Johannes Wilbert (figures 3, 4, 5); William $\mathrm{H}$. and Patricia K. Townsend (figures 6, 7, 8, 9, 11 and 13); The Sarawak Museum (figures 10 and 12) and John Nance (figure 16). All other photographs were taken by Kenneth Ruddle. Noel Diaz and Kathy Marcus drew the maps and diagrams with their customary skill. In many of the areas under consideration, and particularly in Southeast Asia, country and regional names have been changed, often several times, in the postcolonial era. For consistency, we have endeavored to use the name officially recognized at present.

A special expression of gratitude is owed to the Technology and Development Institute, East-West Center, for supporting the Renewable Resources Planning and Development Project, of which this monograph constitutes an intermediate publication and particularly to Marian Inouye, Resource Material Specialist, for handling our frequent demands with such aplomb, and to Helen Hon$\mathrm{ma}$, who with unswerving good humor, typed and retyped the manuscript.

May 1976

Kenneth Ruddle

Honolulu, Hawaii

Dennis Johnson

Houston, Texas

Patricia K. Townsend

Buffalo, New York

John D. Rees

Los Angeles, California 


\section{1}

\section{INTRODUCTION}

Starch is used for a vast number of industrial purposes. Although greatly overshadowed by other starches, sago starch is important in the production of adhesives, particularly those for the laminated paper board industry; in the food industry (monosodium glutamate [aji-no-moto], custard powder, confections, glucose, gravy powders, and sauce mixes); and in the pharmaceutical industry as a bland, odorless, and easily digested filler for drugs and medications. In the petroleum industry, pregelatinized sago and potato starches, provided they can be cheaply obtained, are regarded as superior to maize or wheat starches as additives to coolants and lubricants used in well-drilling operations, because of their viscosity and water-holding capacity (Knight, 1969: 156-157). Sago starch has considerable industrial potential as a raw material for the production of high fructose syrup for use as a sugar substitute (Alagaratnam pers. comm.) and as a filler in biodegradable plastics (Griffin pers. comm.).

Historically, sago starch found its most important industrial outlets in the cotton textile manufacturing areas of the United Kingdom. Because of its cheapness, unmodified sago starch has long been the traditional material for sizing cotton. In addition to low cost, sago starch offers the advantages of relatively low viscosity, reasonable stability, and fairly good weaving results. Among its drawbacks, however, are a bad coloration, enormous variability, and, above all, the difficulty of desizing the textiles 
(Knight 1969:148). Oxidized maize starch has, more recently, been successfully competing with sago in the textile industry. Unmodified sago starch has also traditionally been an important ingredient for backsizing carpets to give them fullness and stiffness.

In the United Kingdom the starch industry was born in the first quarter of the nineteenth century, and was closely linked with the need to stiffen muslin. In 1842 the Brown and Polson Company began selling small packages of sago for household laundry purposes. The 1840 s saw a period of intense competition among wheat, potato, and sago starches, but sago starch held a price advantage, particularly during the Irish potato famine (1845-1847). In the south of England, rice starch, manufactured by the Colmans Company, began to dominate the market. During the period of 1852-1856 the Brown and Polson Company patented a wetmilling process for extracting maize starch, which gradually became the firm's leading product, spreading throughout the British Empire. Meanwhile, another maize starch extraction technology was being developed in the United States. In the opening years of the twentieth century, U.S. maize starch manufacturers established themselves in the United Kingdom and after that time maize starch gradually came to dominate the British market.

At present, most starch production is based on maize, in North America 95 percent of all starch being obtained therefrom. In the rest of the world the situation varies-Australia and New Zealand (wheat and sorghum), Japan (sweet potato), Netherlands (potato) -although the starch industry in each, based on locally grown crops, faces strong competition from North American maize starch exported at very competitive prices.

The worldwide demand for energy foods such as starch and sugar is rapidly increasing, as is the need for pure starch as an industrial raw material. Yet, because of the need to feed a swiftly increasing world population, starches derived from surplus cereals such as wheat and maize will undoubtedly become increasingly scarce in the not too distant future. Moreover, many of these starch-using industries cannot replace starch with sugar, even though sugar may be substituted for starch in some processes. But the cost of sugar has sometimes risen dramatically and the sugar crop is subject to many more agronomic hazards than is sago.

Thus the search by industrial nations for alternative large-scale sources of starch must soon begin in earnest, and as it does, the 
spotlight will certainly fall again on sago, as it did more than two centuries ago, when the starch industry was in its infancy. In some developing nations, the sago palm will probably assume an important role, as the producer of an exportable raw material, rather than as the source of a traditional foodstuff. In such nations the sago palm is doubly important, thriving where few other crops are grown, in isolated swampy regions occupied, ipso facto, by marginal peoples. In parts of the Southeast Asian island world the significance of the sago palm is not unappreciated. It offers an attractive potential of low-cost alternative technologies working though traditional human ecosystems for the development of marginal environments.

Palms are widespread over the surface of the earth, and man has shown remarkable ingenuity in exploiting the available local palm resource to produce an enormous range of useful goods. "Houses, baskets, mats, hammocks, cradles, quivers, packbaskets, bows, impromptu shelters, blowpipes, bows, starch, wine, protein from insect larvae, fruit, beverages, flour, oil, ornaments, loin cloths, cassava graters, medicines, magic, perfume-all are derived from palms"' (Moore 1973b:64). Wild, protected, and cultivated palms are often exploited for a combination of these uses in the humid tropics. Kitzke and Johnson (1975) have surveyed the major commercial palm products other than oils.

Starch from the stems of palms is a product of local importance throughout the mainland and islands of Southeast Asia, in parts of Melanesia, certain islands of Micronesia, and various areas of tropical South America, where it is obtained from the stems of some, mostly native, palm species. Palm stem starch, although often of great local importance in barter and trade, is not a major item of commerce with areas outside the humid tropics. For this reason, starch is commonly overlooked by those outside the producing regions, although it probably represents one of the most important food products derived from palms. At least fourteen species belonging to eight genera (table 1) are exploited, but of these only Metroxylon and Arenga, in the Old World, and Mauritia in the New, are of major importance as palm starch sources.

The difficulties of compiling a general survey of palms should be noted, for although considerable data exist on the five cultivated palms of prime importance to man-the coconut palm (Cocos nucifera), date palm (Phoenix dactylifera), the African oil palm 
TABle 1. Principal Genera Exploited for Stem Starch

\begin{tabular}{|c|c|c|}
\hline Genus & Species & Area \\
\hline Arecastrum & romanzoffianum & $\begin{array}{l}\text { Paraguay } \\
\text { Brazil }\end{array}$ \\
\hline Arenga & $\begin{array}{l}\text { pinnata } \\
\quad \text { (saccharifera) }\end{array}$ & $\begin{array}{l}\text { India } \\
\text { W. Malaysia } \\
\text { Philippines } \\
\text { Indonesia }\end{array}$ \\
\hline \multirow[t]{3}{*}{ Caryota } & $\begin{array}{l}\text { aequatorialis } \\
\text { mitis }\end{array}$ & $\begin{array}{l}\text { Malaysia } \\
\text { W. Malaysia } \\
\text { Kalimantan }\end{array}$ \\
\hline & rumphiana & Kalimantan \\
\hline & urens & $\begin{array}{l}\text { India } \\
\text { Vietnam }\end{array}$ \\
\hline \multirow[t]{2}{*}{ Corypha } & umbraculifera & $\begin{array}{l}\text { Sri Lanka } \\
\text { Philippines }\end{array}$ \\
\hline & utan & $\begin{array}{l}\text { Malaysia } \\
\text { Madura } \\
\text { Sulawesi }\end{array}$ \\
\hline \multirow[t]{2}{*}{ Eugeissona } & insignis & Sarawak \\
\hline & utilis & $\begin{array}{l}\text { Kalimantan } \\
\text { Malaysia }\end{array}$ \\
\hline Mauritia & flexuosa & Venezuela \\
\hline \multirow[t]{2}{*}{ Metroxylon } & spp. & $\begin{array}{l}\text { Papua New Guinea } \\
\text { Irian Jaya }\end{array}$ \\
\hline & $\begin{array}{l}\text { sagu } \\
\quad \text { (rumphii) }\end{array}$ & $\begin{array}{l}\text { Kalimantan } \\
\text { Indonesia } \\
\text { Malaysia } \\
\text { Papua New Guinea } \\
\text { Irian Jaya } \\
\text { Philippines }\end{array}$ \\
\hline Roystonea & oleracea & New World \\
\hline
\end{tabular}

NoTE:

Species names listed may sometimes represent synonyms as recent revisions of the genera have not been completed.

(Elaeis guineensis), the carnauba wax palm (Copernicia prunifera), and the arecanut palm (Areca catechu)-botanical and utilization data for most other palms, including those discussed in this study, are fragmentary. Moreover, as observed by Corner (1966:225), the physiology and ecology of palms have scarcely been examined. Moore (1973b:63) notes also that, with scarcely 
an exception, the study of palm biology is in its infancy, and that almost nothing is known of the soil and water, or light-temperature relationships of palms.

This study focuses on sago starch recovered from the pulverized stem pith of palms through water processing and sedimentation. Starch obtained from seeds, and the direct food use of both raw and cooked stem pith are excluded from consideration. It should also be noted that the term "sago," although originally applied only to starch derived from the stem of Metroxylon palms, is now used to describe starch from the stems of other palms, cycads, and manioc root tubers.

\section{Genera Exploited and their Distribution}

The distribution of the principal Old World genera exploited, Corypha, Arenga, Eugeissona, Caryota, and Metroxylon is depicted in figure 1 .

Although of relatively limited range, Metroxylon is by far the most important genus exploited for stem starch in either the Old or New World. The Metroxylon or sago palms have large pinnate leaves and a stout erect trunk which reaches a height of $10 \mathrm{~m}$ at maturity. Suckers grow from the base of the main stem and may be separated for propagation. In nature, the palms occur in clumps and in relatively pure stands, and occupy lowland, freshwater swamps. At about 15 years of age each trunk produces a large terminal inflorescence after which it dies. Metroxylon occurs naturally from the South Pacific islands, extending westward though Melanesia into Indonesia, Malaysia, and Thailand, where domesticated are indistinguishable from wild species. At present it is an important food source among some native peoples in Papua New Guinea, Indonesia and Malaysia, and cultivated Metroxylon is of commercial importance in Malaysia and Indonesia.

Arenga pinnata, too, is one of the major reported sources of palm stem starch in Indonesia and India. It is also of economic importance as a source of sap for toddy, sugar, and vinegar, and in Indonesia the leaf sheaths yield a commercial fiber. The Arenga palm, which grows singly to a height of 7-12 $\mathrm{m}$ and has large pinnate leaves, begins flowering after 7-10 years, continuing for about 2 years, after which it dies. Arenga pinnata is described as more or less a forest tree, but not entirely restricted to the rainforest, growing at elevations from sea level to about $1,200 \mathrm{~m}$. The 


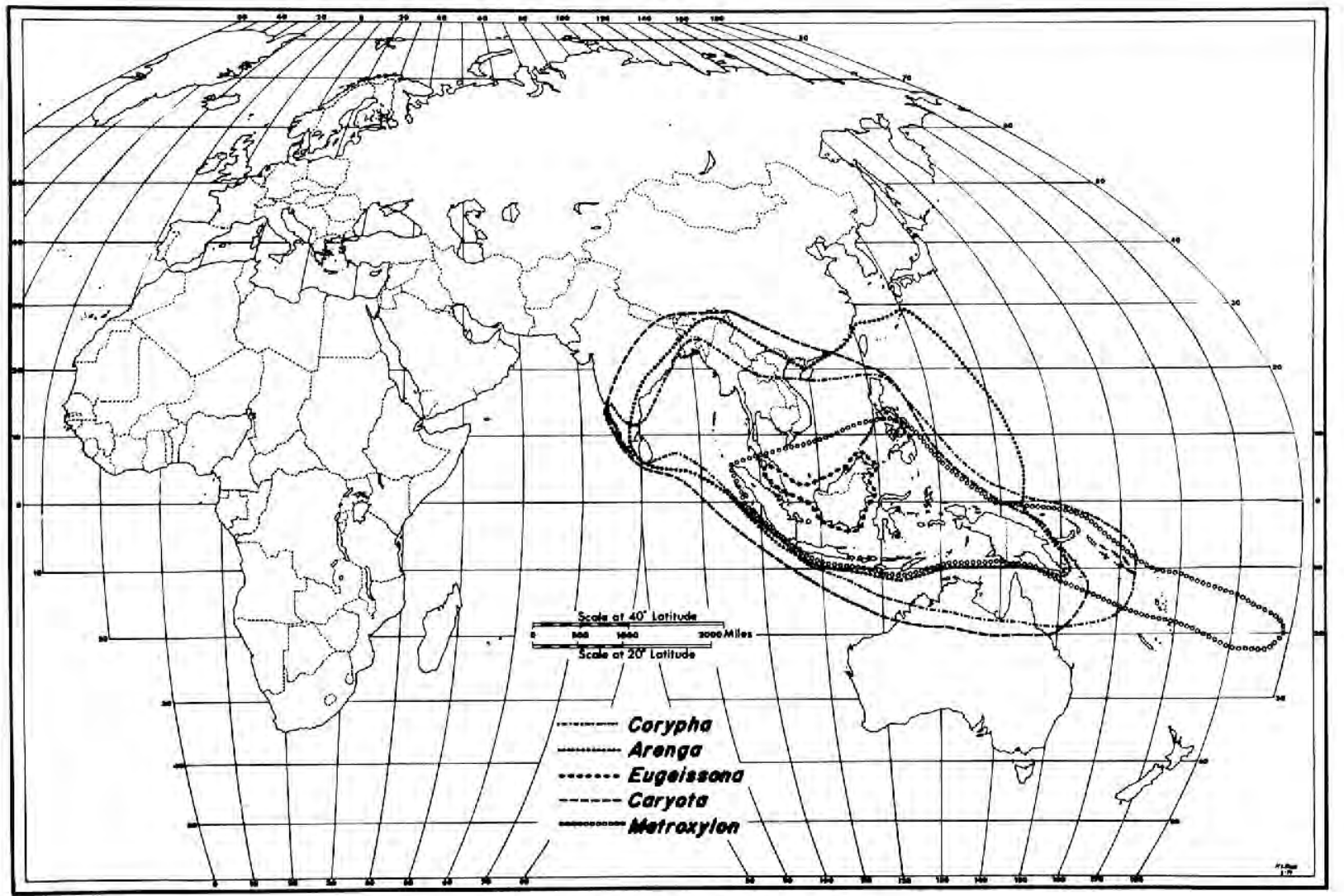

Figure 1. Distribution of Old World palm genera used for sago making. 
palm is cultivated in India. Its range includes South and mainland Southeast Asia, the Philippines, Indonesia, and Papua New Guinea.

Caryota has a distribution similar to that of Arenga, growing in moist tropical forests at elevations up to $1,500 \mathrm{~m}$. Caryota urens is a large, single-stemmed palm which often reaches a height of $20 \mathrm{~m}$, with distinctive bipinnate leaves resembling fishtails. The flowering habit of Caryota urens is similar to that of Arenga pinnata, beginning when the plant is $\mathbf{1 5}$ or more years old, and continuing for several years, after which the palm dies. In addition to producing stem starch, in India and Sri Lanka the inflorescences are tapped for the sap which may be made into sugar or toddy.

Eugeissona has the most limited distribution of any of the principal genera under consideration, being found naturally in only West Malaysia and Kalimantan. Palms of this genus, which have an exceptionally short stem and large, erect pinnate leaves, are common to the tropical forests within its range. Apart from $E$. utilis, which attains a height of $8 \mathrm{~m}$, limited stem development precludes the accumulation of large quantities of starch. Eugeissona palms are only a minor source of starch. Beccari (1904:307) described the use of sago from semicultivated palms of this genus by natives of Sarawak. The leaves and stilt roots have, however, a range of traditional uses.

Corypha is used in South and mainland Southeast Asia, the Philippines, Indonesia, Papua New Guinea, and tropical Australia as a minor starch source. Corypha umbraculifera, the talipot palm, is a massive palm with a trunk which may attain a diameter of 1 meter, a height of $25 \mathrm{~m}$ and which supports large, fan-shaped leaves. Between 30 and 40 years of age the palm produces a huge terminal inflorescence, requiring about a year to develop. The plant dies after the fruits have ripened. Because the talipot palm is unknown in the wild we have no information about its natural environment, although it is clearly of the humid tropics. Its other useful products are leaves that can serve as writing material, and sap, later fermented into palm wine, obtained by tapping the base of the inflorescence.

The geographic distribution of three New World palms, Roystonea, Arecastrum, and Mauritia is depicted in figure 2. Mauritia flexuosa, the principal New World palm exploited for sago, ranges over most of northern South America, in the humid for- 


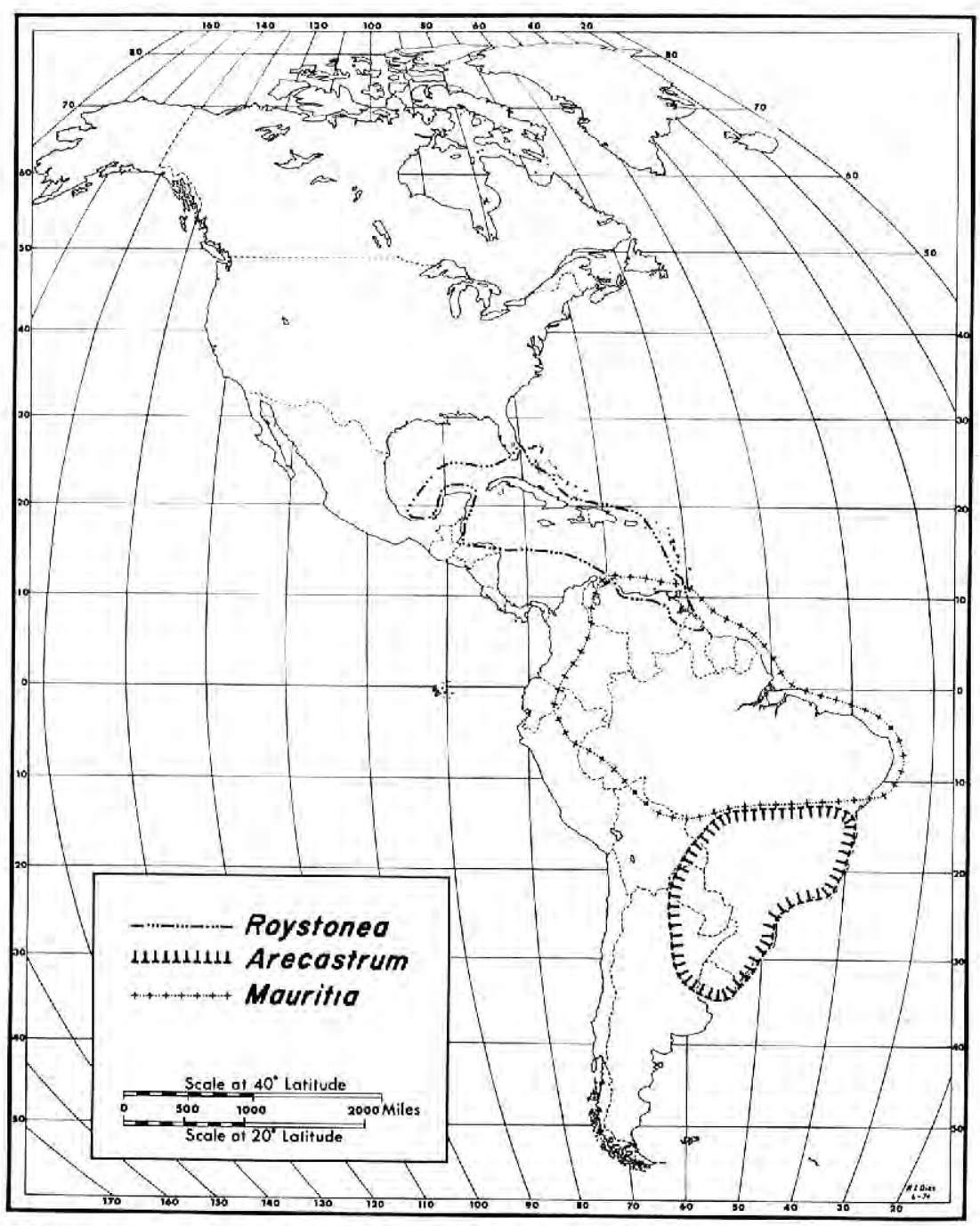

Figure 2. Distribution of New World palm genera used for sago making. 
ests, and especially along streams and in freshwater swamps. Extraction of its starch is at present important in the Orinoco Delta of Venezuela. Mauritia flexuosa palms grow singly up to $25 \mathrm{~m}$, and have large, rigid, palmate leaves. Once botanical maturity has been reached, flowering and fruiting occur annually. In the Orinoco Delta, flowering is in response to the rainfall regime (Heinen and Ruddle 1974:121-3). The palm continues to flower for an undetermined number of years. Parts of this palm furnish a wide range of domestic products and foodstuffs used by the many native groups of northern South America.

The other New World genera are only minor sources of stem starch. Roystonea, which occurs in the greater Caribbean region and in the adjoining portions of North, Central, and South America, is sometimes exploited. Roystonea oleracea, a tall, stately palm which reaches heights of $40-60 \mathrm{~m}$ and has pinnate leaves with leaflets borne in two rows, has an annual flowering season, which perhaps explains the accumulation of stem starch. Mostly, however, palms of this genus are esteemed as ornaments in the tropics, and their wood and leaves are utilized as building materials.

Arecastrum has a range limited to the southeastern part of South America. The queen palm, Arecastrum romanzoffianum, ${ }^{\prime}$ is monotypic, has an erect, solitary, slender trunk $10-15 \mathrm{~m}$ long, and large pinnate leaves. It is a palm of both the tropical and subtropical forest, and like other New World palms considered here has an annual flowering and fruiting season. Arecastrum romanzoffianum is a popular ornamental and street tree in the tropical and subtropical regions of the New and Old World.

It should be noted that figures 1 and 2 map both reported and potential areas of the exploitation of the palm genera included in table 1 , but that the presence of a palm in a particular area does not necessarily imply the presence of palm starch extraction. More difficult is the problem of depicting the distribution of other reportedly exploited genera: Acrocomia, Borassus, Phoenix, Pholidocarpus and Raphia. The genus Phoenix, for example, extends in a broad, continuous belt across the Old World from Taiwan to the Canary Islands. Within that range, however, the extraction of sago from $P$. farinifera is reported only for the Coringa, Deccan and Travancore regions of the Indian subcontinent (Drury 1858: 348 , and Watt 1883:137, both following almost verbatim Rox- 
burgh's observations made during the late eighteenth century) and in unspecified parts of India and Sri Lanka (Blatter 1926:14-17). Over most of the range other products of this palm are used, and such a limited mention of starch extraction does not, in our opinion, merit its inclusion on the Old World map (fig. 1). Further field research may justify inclusion of Phoenix and other genera at a later date. Recently, for example, work in the Orinoco Delta by Wilbert suggests that Manicaria saccifera may, historically, have been a source of sago used by the Warao Indians. 


\section{2}

\section{TRADITIONAL EXTRACTION AND PREPARATION OF SAGO}

The techniques and implements used to extract sago are remarkably similar throughout the tropics, despite variations in detail. In the New World the procedures are best documented for the Warao tribe of the Orinoco Delta (Suárez 1966; Heinen 1972:113; Heinen and Ruddle 1974). The moriche palm (Mauritia flexuosa) provided the preagricultural Warao people with a major source of food during much of the year, and it continues to be an important staple for many local groups as well as a focal point for ritual. Shortly after a harvest festival for moriche starch has been signalled by a priest-shaman, the Warao fashion the implements and sacred instruments associated with the extraction of starch. After such preparations, tribesmen designated to extract starch move into a palm grove and construct a temporary settlement for themselves. Small groups known as "fellers of the moriche" conduct tests for starch content on individual palms. The initial indicator of starch potential is whether or not the palm has produced its annual inflorescence. Those which have not yet flowered are slashed with an axe, and the axe blade examined for adhering starch particles.

The proven palms are felled with an axe, and the woody outer layer removed from the upper side of the downed stem, exposing the pithy interior. Using a traditional adze made from moriche 
wood, a man chops the pith (figure 3 ). The chopped pith is then collected by women and packed into large conical baskets made from moriche leaf fiber (figure 4). The pith is placed on a sieve and hand kneaded while water is poured over it to remove the starch (figure 5). The filtering sieve, woven from moriche leaf fiber, is supported by four sections of moriche leaf petiole, over a pair of nested containers into which the liquid drips. Starch particles settle to the bottom of the inner container while the water overflows into the outer vessel. The overflow is refiltered several times to ensure that all starch is extracted. Similar tools and techniques were used formerly to extract starch from the temiche palm, Manicaria saccifera (Wilbert 1976).

The procedures described above for the Warao of the New World are similar to procedures used in the Old World. ${ }^{1}$ This chapter will describe the various methods by which sago is extracted, stored, and cooked in the main producing areas.

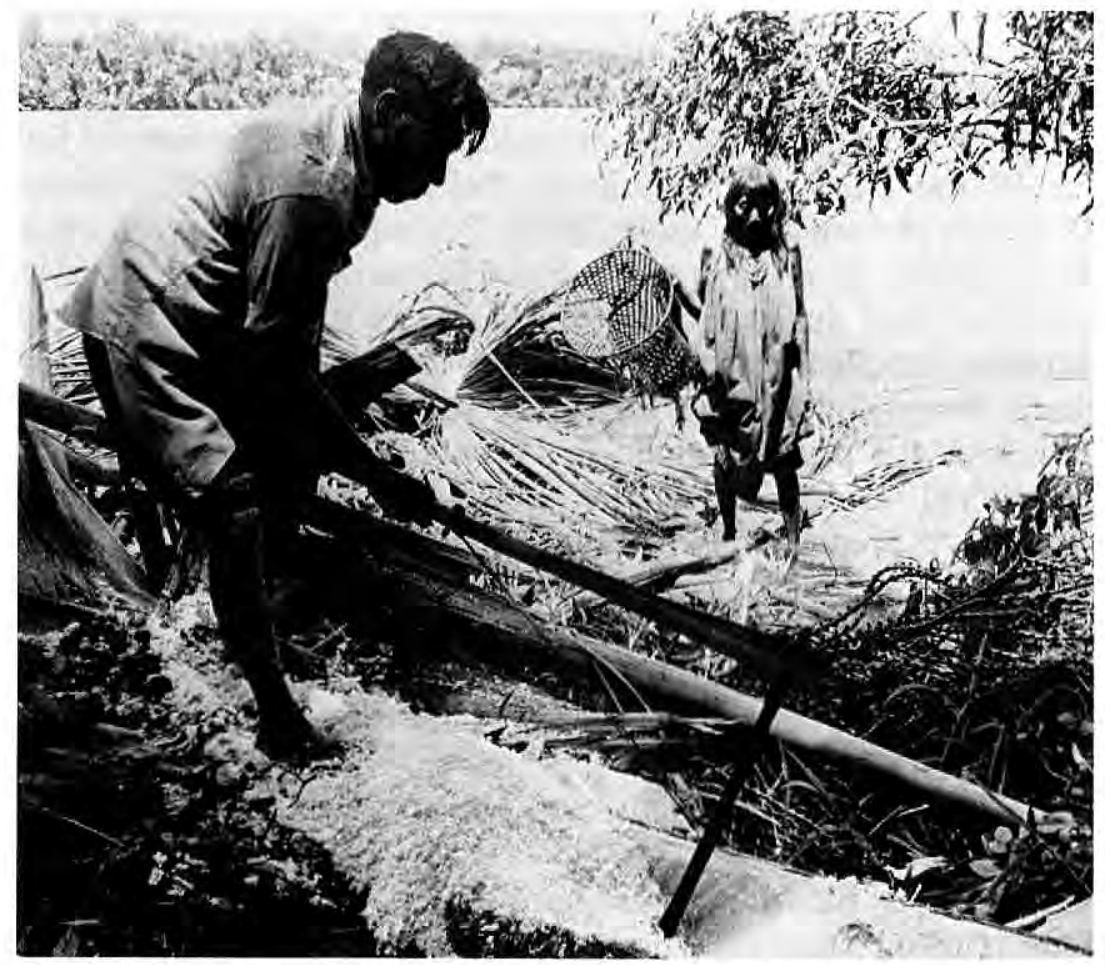

Figure 3. Warao man using adze to chop pith of Mauritia palm. 


\section{Selection, Testing, and Felling}

The criteria by which sago palms are selected for cutting are the most poorly documented aspect of sago processing. The starch reserves are apparently at their maximum just before flowering and fruiting deplete these reserves, but scientifically little more is known of the timing of starch buildup. Most sago-using peoples cut palms at varying stages of maturity. For example, the Melanau of Sarawak cut Metroxylon at several stages from completion of growth of the crown, through flowering, until the early stages of development of the fruit, claiming that the best starch yields are obtained in the early fruiting stages (Morris 1953:153-154).

The Moluccans claim that the optimal period for starch yield is the final period of growth before flowering, which can be identified by the whitening of the leaf stalks (Sprecher von Bernegg 1929:296), but they also cut a plug to check the pith before felling the palm.

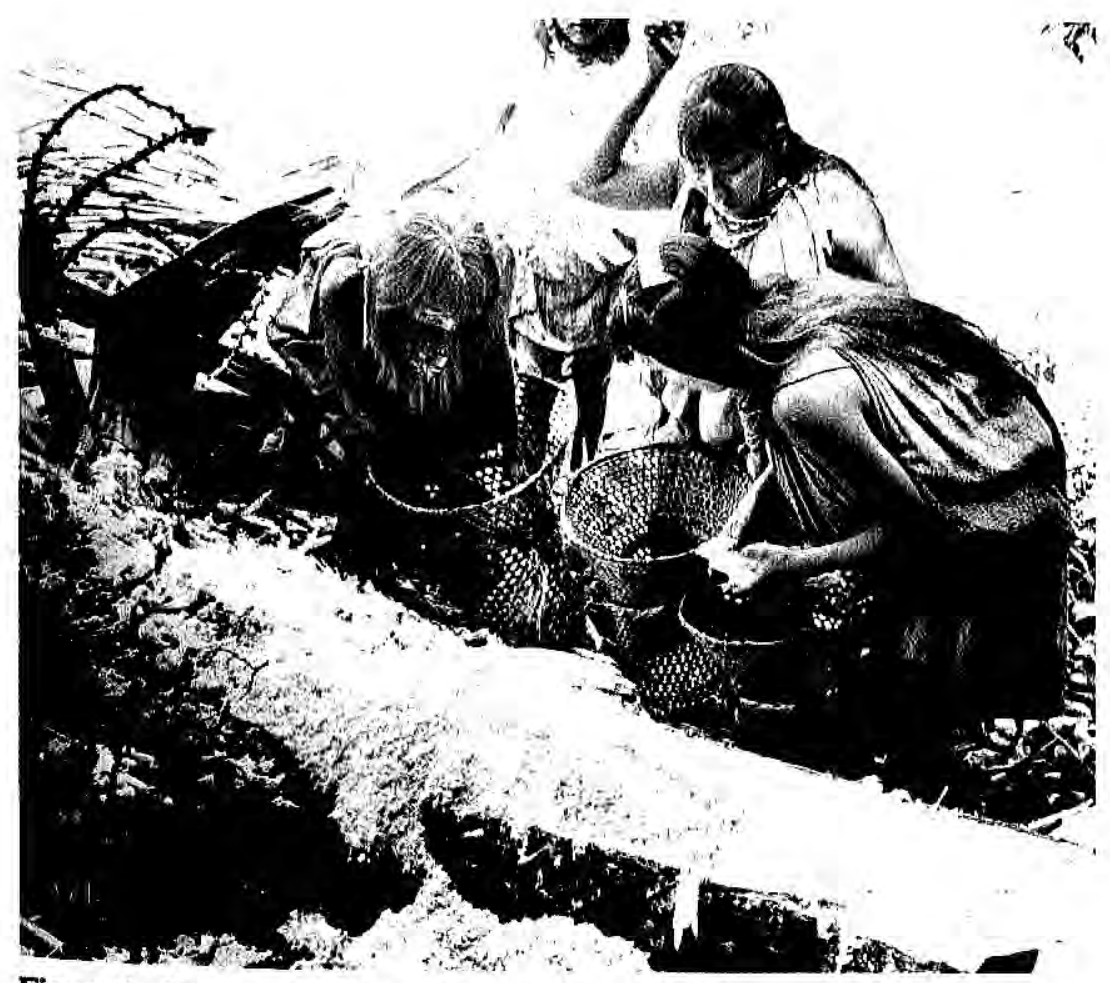

Figure 4. Warao women collecting chopped pith. 


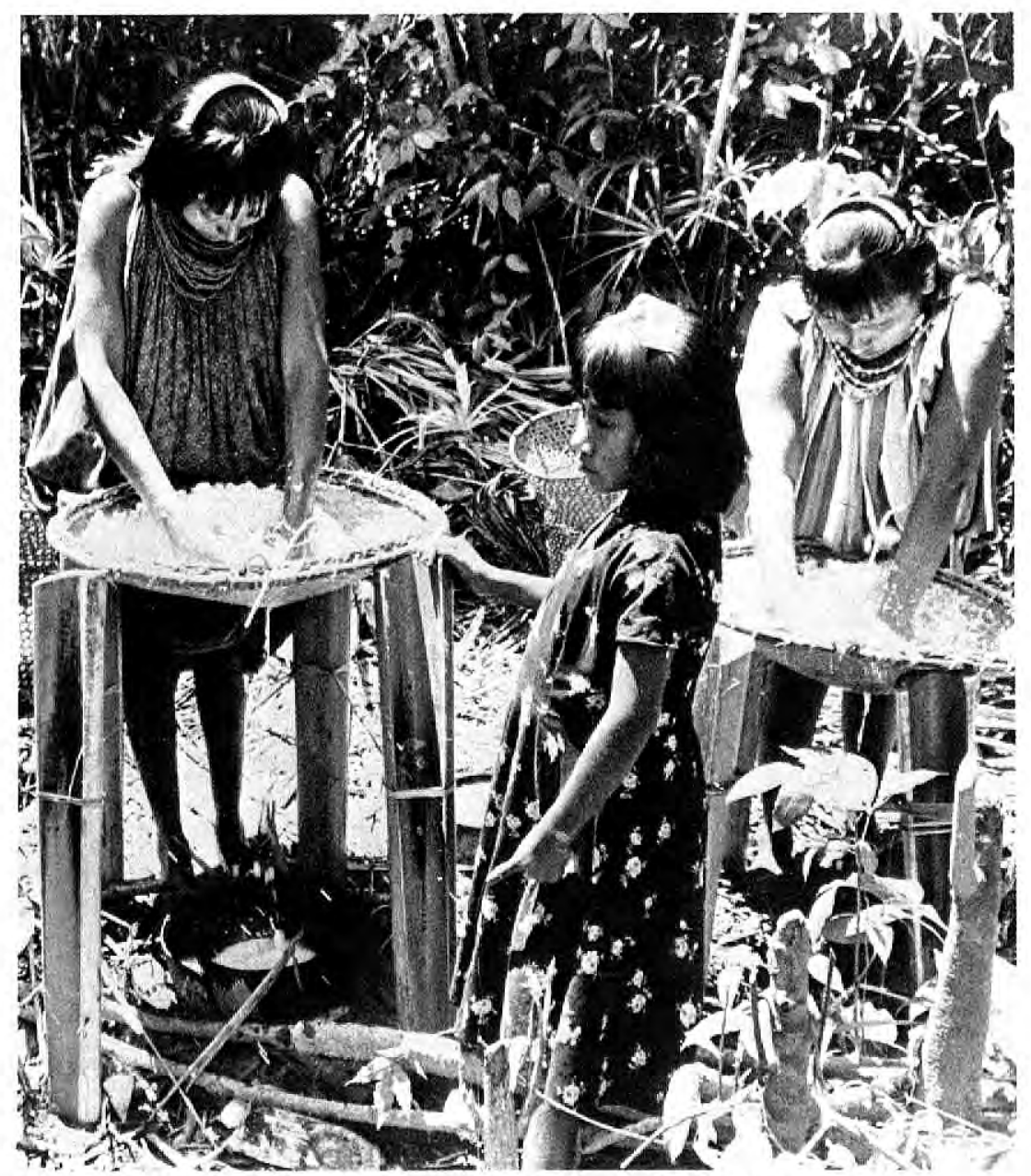

Figure 5. Warao women kneading pith to express starch. 
Testing for starch content by sampling the pith is reported only sporadically. Such reports come from the Sepik River of Papua New Guinea, where a sample of the pith is sometimes chewed (Speck 1951:41), from the Asmat of Irian Jaya (Amelsvoort 1964: 36), the neighboring Mimika area (Pouwer 1955:35), and the Philippines (Hines 1914:228). Fernandez and Lynch (1972:306) note that although test cuts are made, some Tasaday claim that they can assess starch content by knocking on the trunk with the knuckle, or by tapping it with a piece of wood. On Normanby Island, Schlesier's informants tested the pith and pronounced it good, but later they found the yield of the entire palm disappointing anyway (Schlesier 1965:8).

The Toradja of Sulawesi also test starch content (Adriani and Kruyt 1951:201-202). Prior to testing a large palm they test a small palm in order to appease particular spirits who would otherwise, it is thought, cause the starch in the larger palm to disappear. After that precaution, a small hole is chopped into the pith of the palm into which a square-cut stick is thrust and twisted several times. The palm is felled if starch grains adhere to the stick when it is removed. It is also reported that some Toradja use divination to assess starch content. A stalk of Maranta dichotoma, about $2 \mathrm{~m}$ long, is cut, measured, and placed against the palm which they propose to fell. The stalk is addressed, and asked to indicate whether or not the palm contains a large quantity of sago. The stalk is again measured, and if it appears longer, the increase in length is taken as an affirmative response, and the palm felled for sago. Adriani and Kruyt (1951:201) state that the Toradja say that: "The Metroxylon recognizes the aren (areng) palm as its master ...., and the latter is subject to the aroeroe (Caryota Rumphiana)." The use of a physically smaller palm to appease the spirits may well be connected with the Toradja's hierarchical concepts regarding sago-producing palms.

The palm is normally felled promptly after selection, but in some areas the inflorescence may be cut off and the trunk left standing for a year or more, thereby preserving the starch for future use. In Cavite Province in the Philippines, where sago is derived from palms of the genus Arenga, inflorescences are removed as they appear and the palm is left for about twelve months before testing for starch content. Trunks are tested by notching with an axe and examining sections of the pith (Hines 
1914:227-228). In the Fly River area of Papua New Guinea palms of the genus Metroxylon may be left standing for up to five years after the removal of the inflorescence (Riley 1923:145; also 1925:60). The Toradja of Sulawesi sometimes cut off the crown of an Arenga palm in advance and plant ginger on the cut surface. This is said to make the palm yield much sago. The Toradja have extensively ritualized the production of sago, as has already been suggested above in discussing their divination procedures for assessing starch content. Ginger, the magical plant used in this ritualized delay between cutting the crown and felling the trunk, also appears in Toradja curing ritual and war magic.

Throughout the sago-using areas the palm is normally felled with an ordinary iron or steel axe. In a few cases, however, there is evidence of specialized tools for felling sago palms, which were undoubtedly of wider distribution before the introduction of iron. In the Lake Kutubu region of southern Papua New Guinea stone tools were still in use in 1938-1939 (Williams 1940:146). The Kutubu regarded their imported stone axe/adze blades as too valuable to risk chipping them on the tough outer layer of Metroxylon. Therefore, in cutting sago they used a locally made stone tool, the head of which was like a pick and pointed at both ends. This tool seems to be identical to the sago-cutting picks still in use at a more recent date in the Sepik area of Papua New Guinea, as reported and illustrated with line drawings by the Townsends (W. Townsend 1969:200-201; P. Townsend 1969:27-28) from the Wogamus River, a tributary of the Sepik, and by Dornstreich (1973:206) and Haberland and Seyfarth (1974:117-118) from the upper Korowori River, another Sepik tributary. The Townsends observed in timing the cutting of sago palms that the stone sagocutting tool was approximately as efficient as the steel axe. After the palm is felled it may be cut into sections to facilitate moving it or, more often, it is simply split open where it lies, by the use of a hardwood digging stick or wedges.

\section{Removing the Pith}

The pith of the various sago-yielding palms is removed from the trunk by use of an adze or hammerlike tool (figure 6). The man or woman wielding the tool uses a combination of scraping and pounding action which reduces the fiber to small pieces and loosens the adhering starch particles (figure 7). The adze handle is nor- 
mally made of wood and the head of wood, bamboo, or stone, with the various materials and forms showing no clearly regional distribution. Wooden sago pounders are usually slightly hollowed out at the working end, so that their cutting edge is very much like the bamboo tools. Wooden sago pounders are reported from several locations in Papua New Guinea including the Fly River (Riley 1923:145) and Kiwai Island (Beaver 1920:162), Wogeo (Hogbin 1939:306) and the upper Korowori (Haberland and Seyfarth 1974:120, Dornstreich 1973:207 and illus. p. 332), and from several locations in Irian Jaya including Waropen (Held 1957:346) and Kaowerawedj (Eechoud 1962:138). Wooden sago pounders are reported from the Kai and Aru Islands in southern Maluku, Indo-

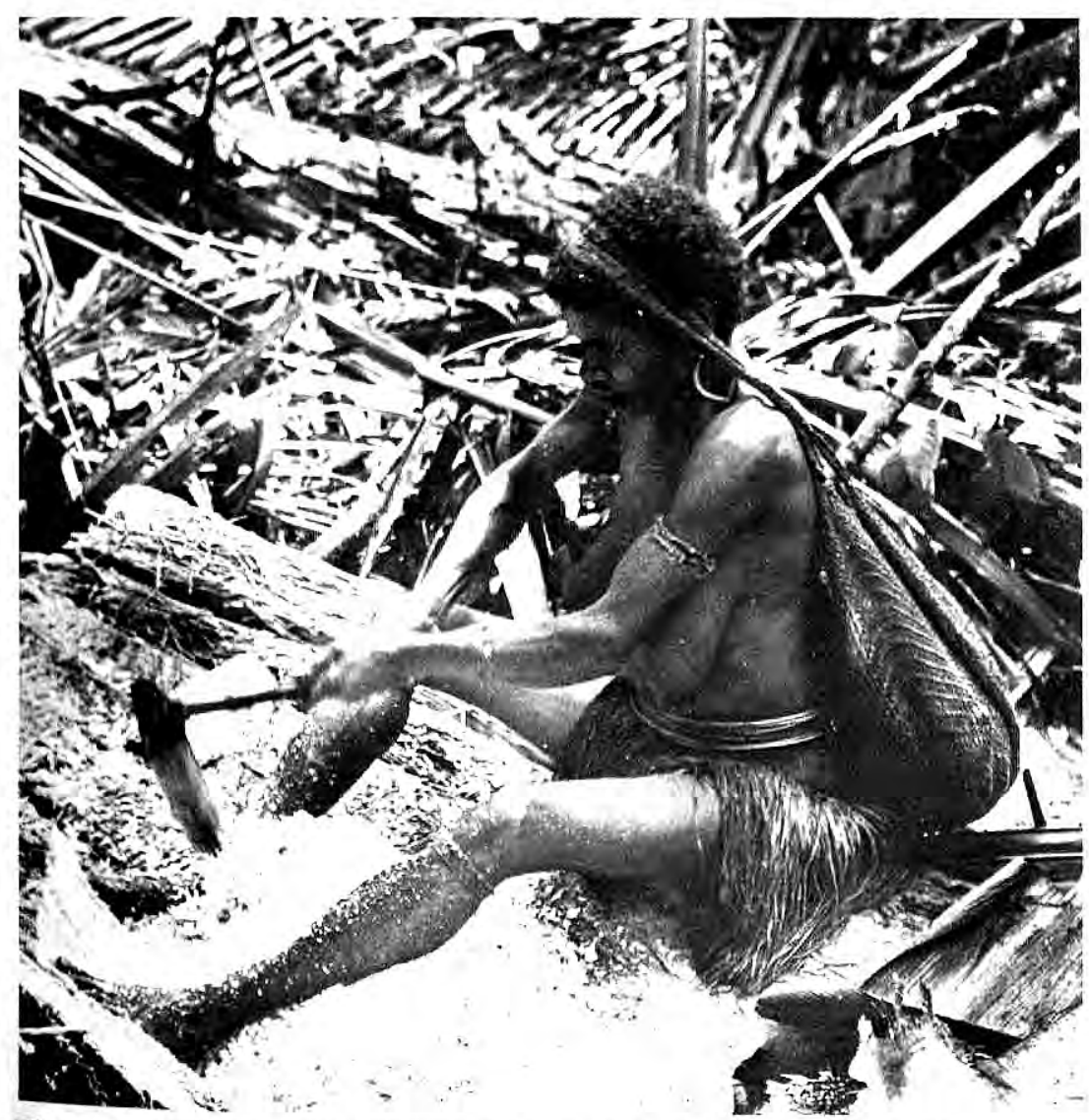

Figure 6. Sanio-Hiowe woman chopping pith of Metroxylon palm. 


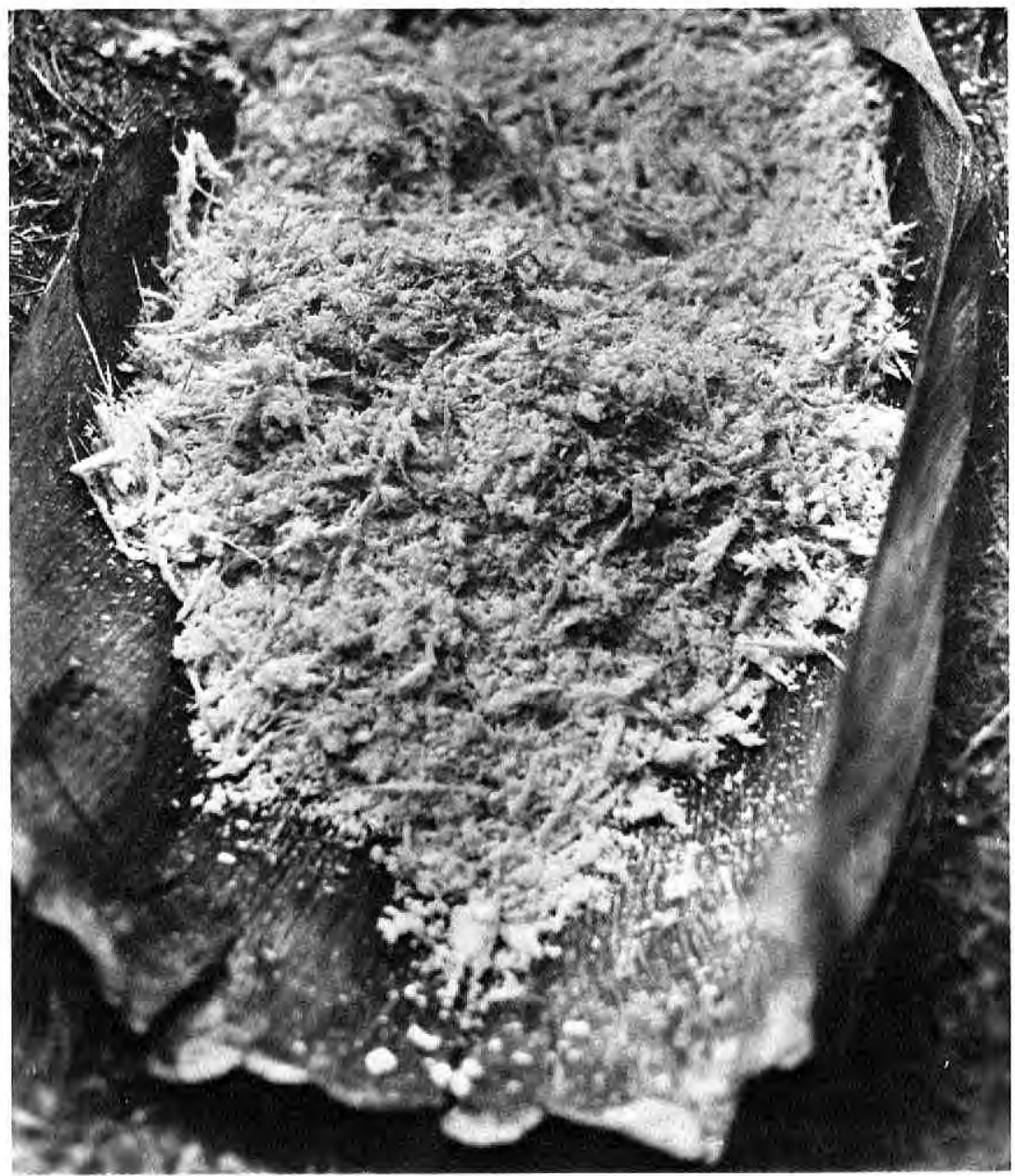

Figure 7. Loosened Metroxylon pith ready for Sanio-Hiowe processing.

nesia (Nutz 1959:15). Wooden sago pounders are also reported for the Philippines (Fernandez and Lynch 1972:298), and wooden-pointed adzes were used by the Melanau of Sarawak prior to the introduction of rasps made of nail-studded boards (Morris 1953:25).

Bamboo sago pounders are found in Papua New Guinea (Williams 1936:423), the Solomon Islands (Oliver 1955:29), Irian Jaya (Wirz 1922:88 and Plate 28; Amelsvoort 1964:36), Ambon (Tupa- 
mahu 1909:116 and illus. facing p. 112), Halmahera (Fortgens 1909:88 and illus. facing p. 104), western Seram (Tauern 1918: 103), Tanimbar (Drabbe 1940:82), and among the Bila-an in the Philippines (Cole 1913:140).

Stone-headed sago pounders are found in scattered locations throughout Papua New Guinea including Kutubu (Williams 1940: 146), Mailu (Malinowski 1915:599 illus.), Sanaroa Island in the Massim area (Malinowski 1922:377), Dobu (Fortune 1932:207), among the Hopoi of the Finschaven area (Streicher 1934:236) and the Sepik area (Mead 1970:143, Townsend 1974:223). A round, sharp-cornered piece of stone set into the bamboo head of the sago-pounding tool is used in central and eastern Seram (Tauern 1918:103). Stone sago pounders are sometimes used by the Tasaday of the Philippines (Fernandez and Lynch 1972:306), and in the New World, the Guayaki of eastern Paraguay are reported to use the back of a stone axe as a sago pounder (Métraux and Baldus 1948:436). In some areas pieces of iron or pipe have been incorporated into the sago pounder (Wogeo, Hogbin 1939:306308; Tikopia, Firth 1950:272; Toradja, Adriani and Kruyt 1951: 203). Tikopia is also noteworthy for the use of hand-held (unhafted) coconut-shell scrapers (Firth 1950:273).

As the above survey indicates, wood, bamboo, and stone pounders are each found in several areas exploiting different palm genera; that is pounders made of any of these materials may seemingly be used to exploit the various palms. However, there are differences between the palms in the relative difficulty of removing the pith, and in areas in which more than one palm genus is exploited, there may be specialized pounders for the different palms. For example, the Toradja, who use a stone pounder for Metroxylon, which is their usual source of sago, use a sharp-edged hammer of pandanus wood for chopping the harder fibers of Arenga (Adriani and Kruyt 1951:204). In Halmahera, Indonesia, bamboo sago pounders are used for both Metroxylon and Aren$\mathrm{ga}$, but the one for Arenga is of a harder type of bamboo and of sturdier construction (Fortgens 1909:104).

Alternative methods for the preparation of pith are less widely distributed. In Cavite Province in the Philippines (Hines 1914: 228), the trunk of Arenga is chopped into small pieces with a bolo or large knife, and the pieces are pounded to a coarse meal in a 
wooden or stone mortar. While the meal is kneaded and washed to remove the starch, coarser particles are taken back for additional pounding until all the starch is extracted.

The Guaraní of southern Mato Grosso, Brazil, who in earlier times ate palm stem starch, used a somewhat different technique to extract sago from the stem of the pindo palm, Arecastrum romanzoffianum (Henry 1964:163; Métraux 1928:68, 1948:453; Watson 1952:28). Henry described the extraction process as follows: "Leaves are laid on the ground and a cloth placed on top of them. The trunk is chopped vertically into strips; these are placed on a log and pounded with a stick. The mass is sifted in a basket." Metraux, however, notes that the pith was crushed in a mortar before being sieved and then sun dried. Another South American group using the pindó palm is the Guayaki of eastern Paraguay, who speak a dialect of Guarani. They, too, process sago flour by sifting the pounded pith through a sieve, which is described as a small "crude square sieve, a mat made of bamboo splinters or Carex stalks"' (Métraux and Baldus 1948:436; Clastres 1972:156). South American Arecastrum sago is the only type that is thus regularly extracted by a process that does not use water, although there are occasional reports of Old World peoples who normally process sago by sedimentation occasionally taking a raw or cooked chunk of sago pith, chewing it, and spitting out the fibers (Wollaston 1912:91; Alkema and Bezemer 1927:364). There are also fragmentary reports of Indonesian peoples practicing dry extraction of sago as an alternate technique in Timor (Wortelboer, cited in Nutz 1959:17) and in Tanimbar (Drabbe 1940:84).

In most areas the next step is to wash the starch from the prepared pith. This is done immediately after pounding in most cases, but some groups claim that more thorough extraction is possible when the pith is allowed to stand. In Tikopia, the scraped pith of Metroxylon, packed into large wooden bowls and covered with leaves of the giant taro, is allowed to stand for a day or two so that the starch separates from the fibrous matter (Firth 1950: 273).

\section{Washing, Filtering, and Settling Out}

A broad division can be made between the method of kneading sago pith with water by hand in a trough and the method of tram- 
pling the pith with the feet. In either case the water in which the starch is suspended runs off through a filter into a settling vessel. In much of Papua New Guinea, Irian Jaya and Maluku the entire system of troughs constructed for the starch separation process is fabricated from portions of the felled Metroxylon palm (Barrau 1959:156; Tauern 1918:104). This is the case, for example, with the Mimika of Irian Jaya (Pouwer 1955:36), the Marind-anim (Wirz 1922:89), the Kiwai Papuans (Beaver 1920:162), the Orokaiva (Williams 1930:59), the Yimar of the upper Korowori (Haberland and Seyfarth 1974:230) and the Sanio-Hiowe (figure 8). Even in areas where the settling trough is made of some other material, the washing trough is usually constructed of the broad leaf base of the sago palm.

The trough is usually set up near a stream and water is supplied

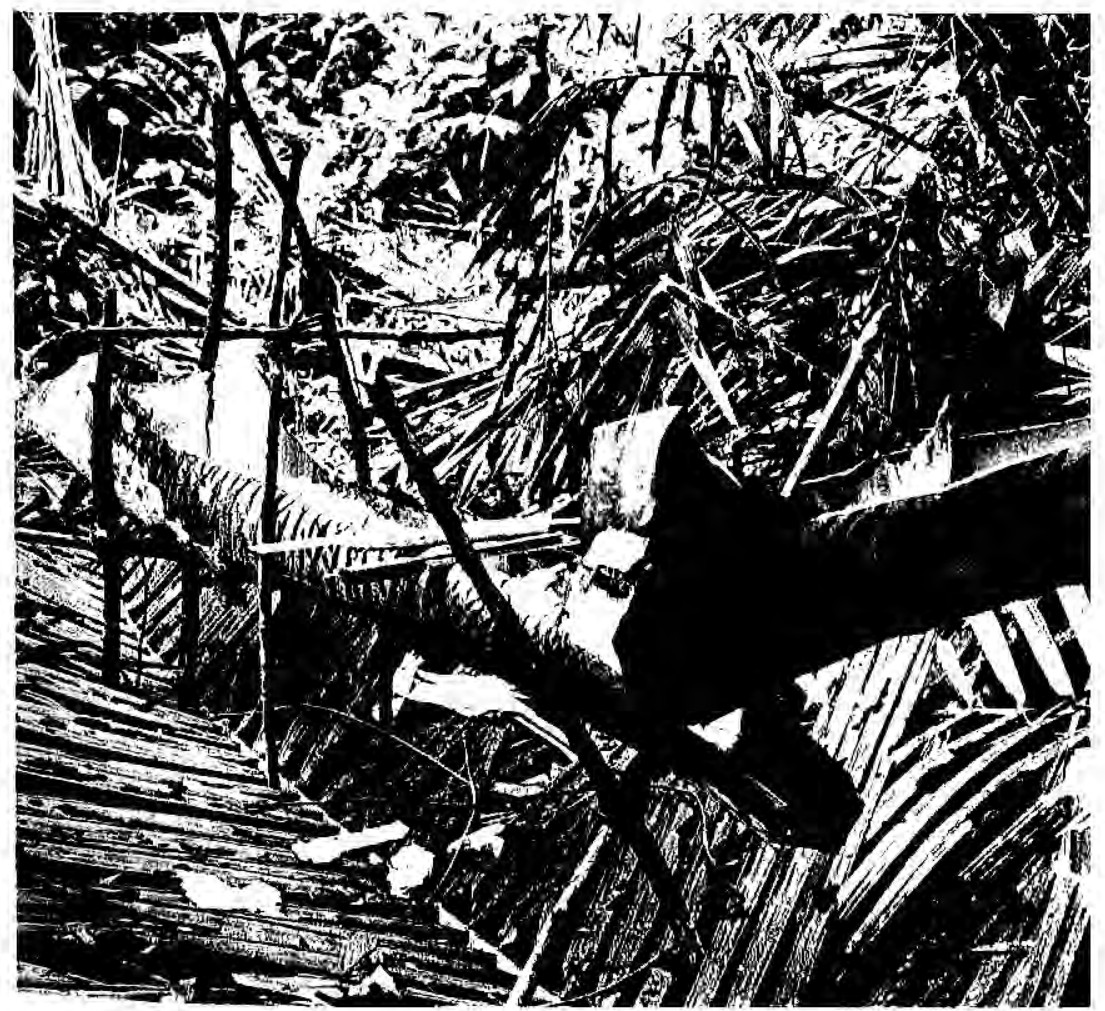

Figure 8. Apparatus constructed by Sanio-Hiowe for processing of sago. 
by a simple long-handled dipper of palm spathe or coconut shell. Only rarely is the water supplied by a more elaborate system. The Bila-an of Mindanao, described by Cole (1913:140), build bark troughs near a source of flowing water and lead water to the trough by means of bamboo conduits. On Seram, Maluku, the starch separation process almost assumes the scale of light engineering, with the construction of an elaborate trough and conduit system and the fabrication of an assortment of filtration baskets and vats (Tupamahu 1909:facing page 112; Wallace 1885:383384).

As the pith and water are kneaded together, the water carrying suspended starch runs off through a filter (figure 9). Throughout New Guinea and eastern Indonesia wherever the pith is kneaded by hand this strainer is most frequently a fibrous coconut leaf sheath: as in Kiwai (Beaver 1920:162), Orokaiva (Williams 1930: 59), Arapesh (Mead 1970:143; and figure 6), Yimar (Haberland and Seyfarth 1974:229), Sanio-Hiowe (Townsend 1974:223), Alfendio (Haberland 1966a:57), Marind-anim (Wirz 1922:89), and Kimam (Serpenti 1965:47). Other materials used as filters include matting from the sago palm itself (Oliver 1955:29; Held 1957: 347), coarse woven cloth (Cole 1913:140), woven rattan (Amelsvoort 1964:36), leaves, bark cloth, or the fibrous nest of an unidentified insect (Townsend 1969:30). In some areas the pith is placed in a bag in the washing trough before being kneaded by hand or beaten with a stick (Haberland 1966a:57 illus.; Williams 1936:422, 1940:153). In Tikopia the pith is kneaded in a basket which is supported over a settling trough (Firth 1950:135).

In comparison to the kneading method, the trampling method seems to have a more limited distribution. Williams (1936:422423) describes and illustrates a low platform made of sago midribs on which the Keraki of the Fly River, Papua New Guinea, trample their sago in a bag. The Toradja of Sulawesi trample sago pith in a wide-meshed basket resting on a stand built over a river or pool (Adriani and Kruyt 1951:203-204). However, the Toradja are also familiar with the other method, using a small trough with a coconut fiber filter at the end, against which the pith and water are kneaded. The hand method is used when a small quantity of pith is being processed. Both the hand kneading method and the trampling method are widely used in Indonesia (Oijen 1909:32-34). 


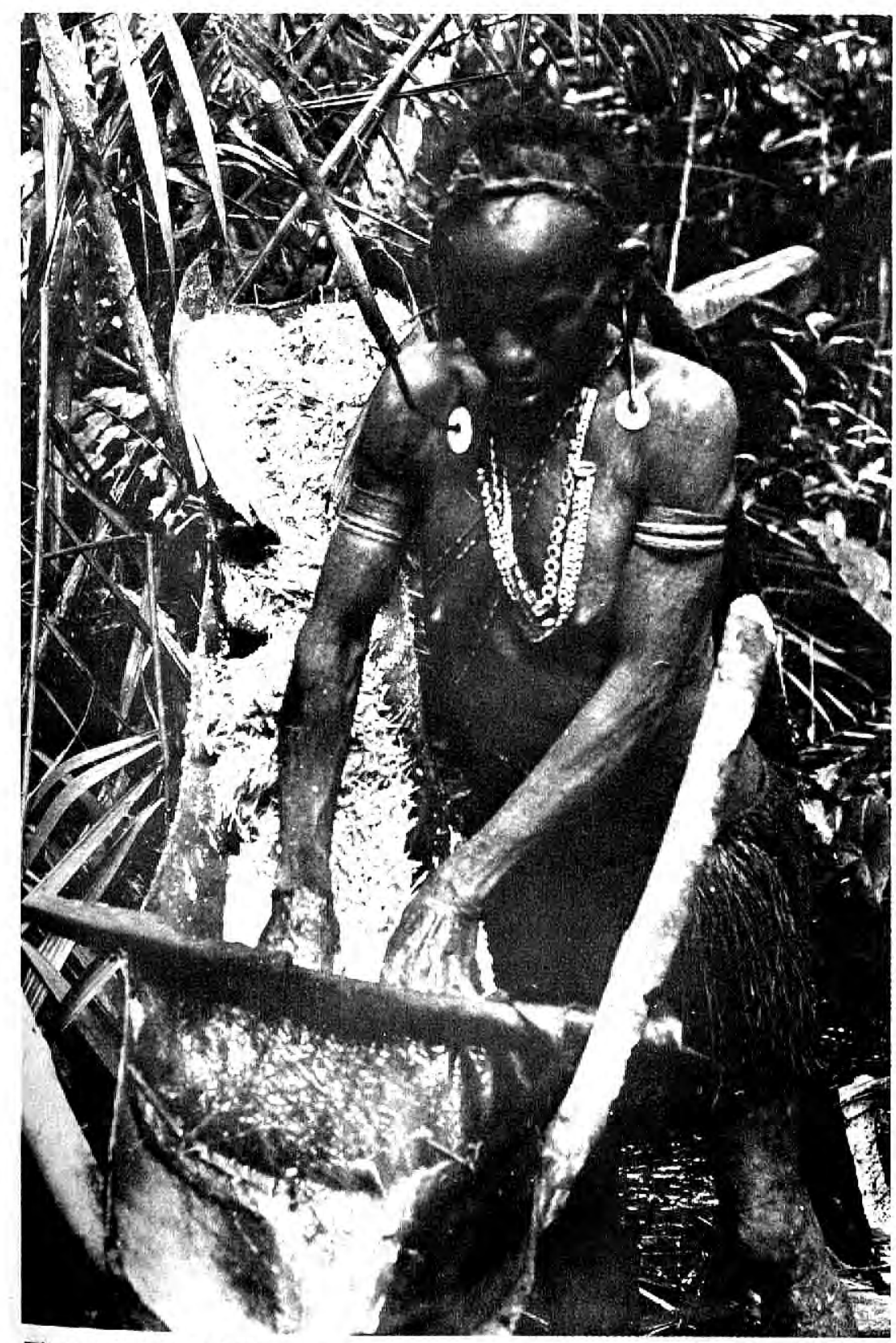

Figure 9. Sanio-Hiowe woman kneading pith to express starch, which passes in suspension through a filter. 
The Melanau of Sarawak, who process large quantities of sago as a cash crop as well as for subsistence, build trampling platforms at the river edge or on floating log platforms (Morris 1953:18, 28; see figure 10).

As the sago pith is kneaded, beaten, or trampled, the added water containing the suspended starch flows into a settling vessel. These vessels vary in cost and permanence from a simple trough made on the spot from a section of the leaf base of Metroxylon to a hardwood trough carved by specialist craftsmen (Tikopia, Firth 1950:135; see figure 11). Vessels made by folding the leathery spathe of the limbum palm are common in New Guinea (e.g., Serpenti 1965:47; Mead 1970:145). Bark or hollowed log troughs are widespread in Indonesia and the Philippines, and in Sarawak long-lasting ironwood troughs are purchased by the Melanau from the Sea Dyaks (Morris 1953:18; see figure 12).

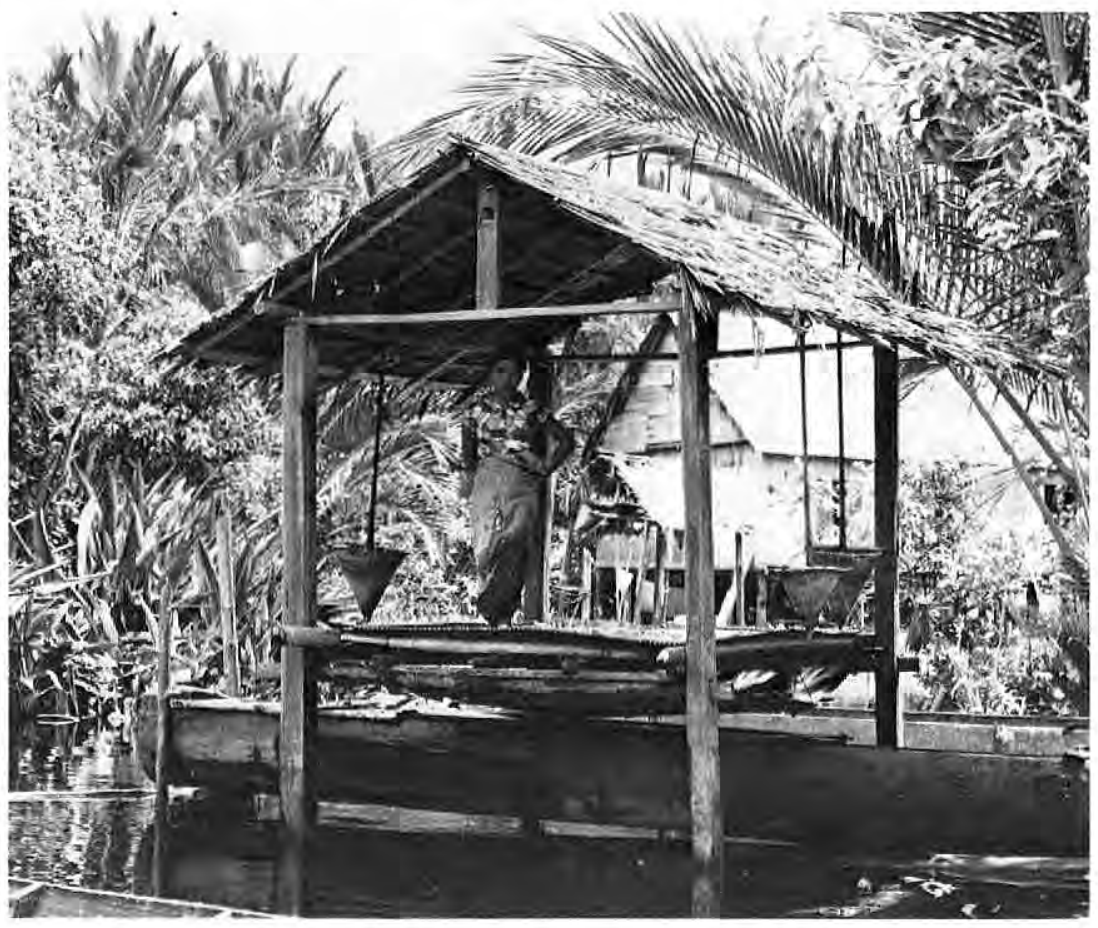

Figure 10. Trampling platform formerly used by Melanau women of Sarawak to process sago. 


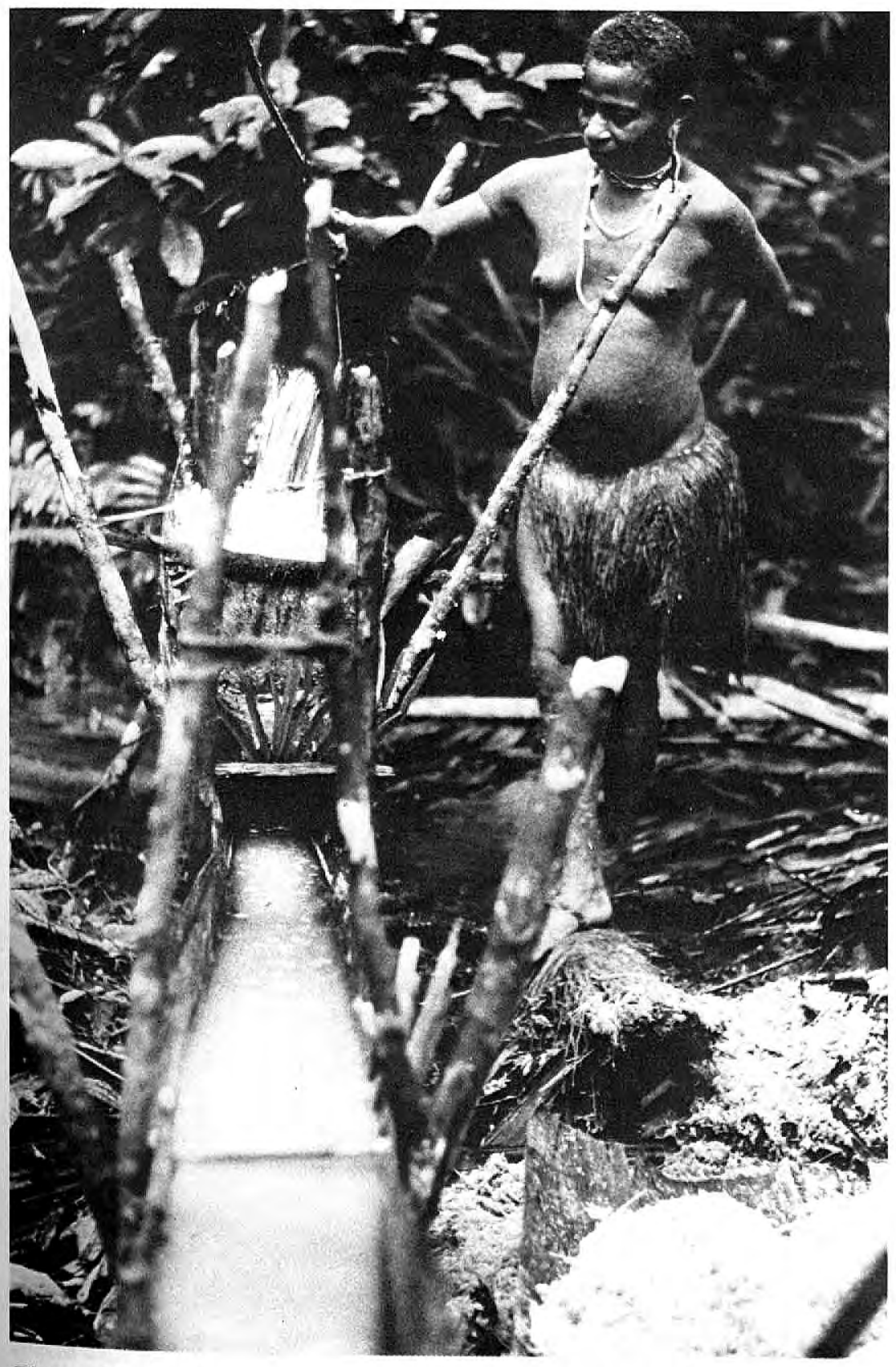

Figure 11. Sedimentation trough constructed by Sanio-Hiowe. 


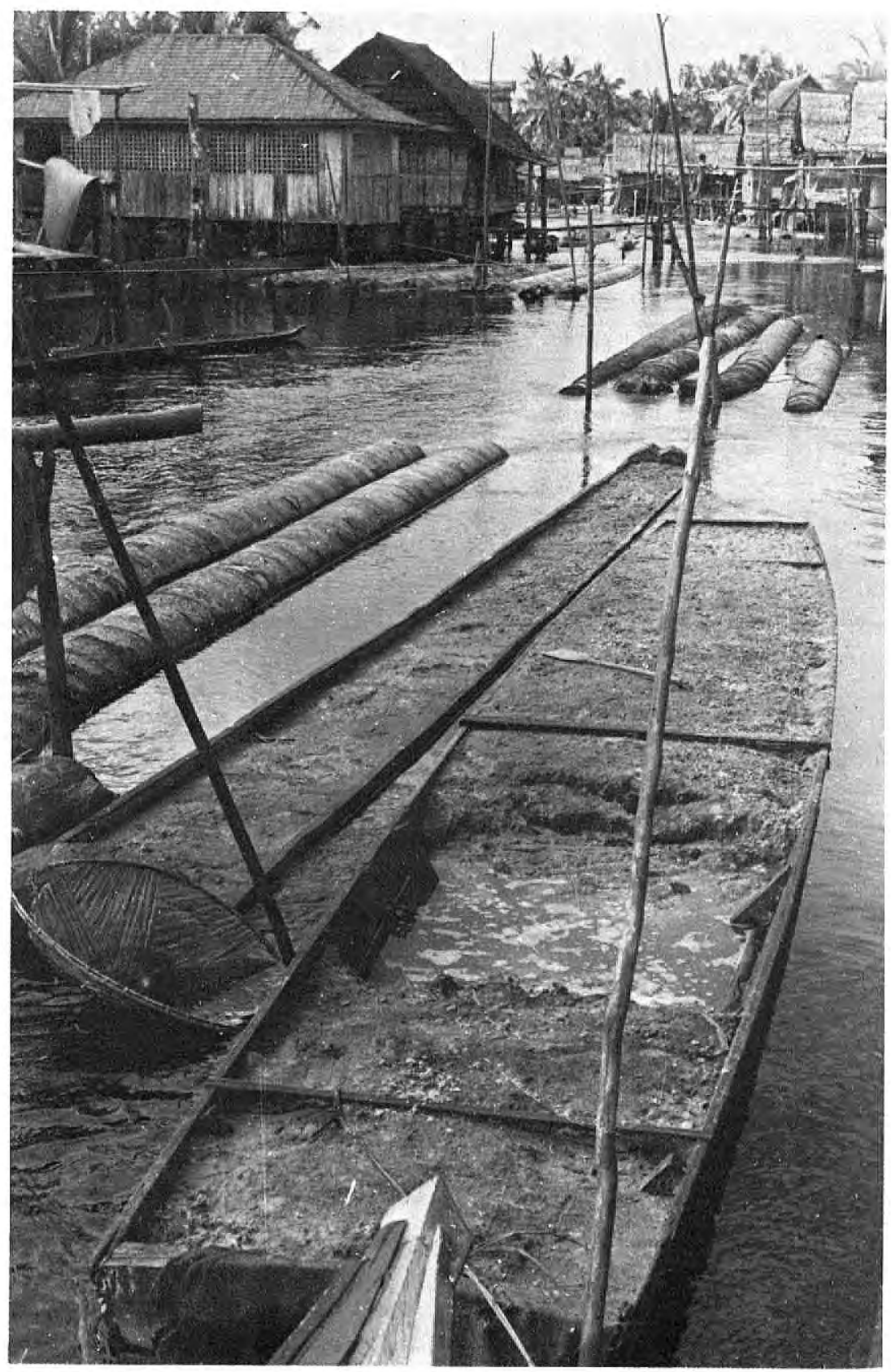

Figure 12. Vessel formerly used by the Melanau for starch sedimentation. 


\section{Storage}

The fact that sago may readily be stored for many months makes it significant in trade, travel, and accumulation for feasting in the tropical regions where it occurs. Commonly it is the final product, the raw starch, which is stored, though earlier reference has been made to cutting the inflorescence in order to keep the mature palm until needed. An unusual storage practice is followed by the Kimam of Dolak Island, Irian Jaya, who remove only the pith needed for immediate use and store the remainder of the log under water until needed (Serpenti 1965:47).

Among the Sanio-Hiowe of Papua New Guinea (Townsend 1974) two forms of storage are practiced. Poyva nau, 'sun sago', is sago flour wrapped in leaves in packets of 10 to $20 \mathrm{~kg}$ and hung from a stump or tree to dry in the sun. Sago stored in this way may be kept for several weeks. Sa'i nau, 'water sago', keeps for several months. In this case, the leaf-wrapped package is buried under mud and water in the sago swamp (figure 13). A similar storage practice is reported from South America, where the Warao customarily keep starch intended for nonritual purposes for many months prior to cooking. To prevent spoilage they compress it into large balls and elongated loaves, which are wrapped in leaves, tied with vines, and then buried under water in river mud. These Indians use a metal pot to bake such sago into small cakes (Turrado Moreno 1945:61-129).

The storage of sago flour may be extended by heating or toasting it in some manner. The Wogeo wrap starch in bundles of leaves which are burned off, then put it in bags in a loft over the fireplace (Hogbin 1939:307). The Hopoi and the Orokaiva of Papua New Guinea similarly singe sago loaves, forming a brown rind under which the firm, dry sago keeps well (Streicher 1934: 237; Williams 1930:60). In Tikopia sago is sun dried unless longer storage is desired, for which wet starch is pressed into slabs and cooked in an oven (Firth 1950:136).

\section{Pearl Sago Production}

Much of the sago used for subsistence purposes in Southeast Asia is consumed as pearl sago. In Sarawak pearl sago is generally produced and consumed by individual family groups. Surpluses are sold to nonproducing villages and in the local bazaar, but virtually no pearl sago produced in Sarawak enters into either inter- 
regional or international trade. Because of the greatly increased price of rice in the last few years (now approximately $\$ 1.0 \mathrm{M}$ per kilo), some villages are producing more pearl sago than ever before (Wee pers. comm.). During July 1975 Ruddle observed pearl sago production in Sarawak at Kampong Baru, a Melanau village close to Dalat. Although some Melanau pearl sago producers undertake all of the stages of sago production, beginning with felling, in Kampong Baru sago flour is now purchased in order to make pearl. In that village the sedimentation tanks and trampling platforms, long since disused, are overgrown with vegetation and are now heavily decayed. Some Melanau bakehouses are built over water as a precaution against an escape of fire destroying other village structures.

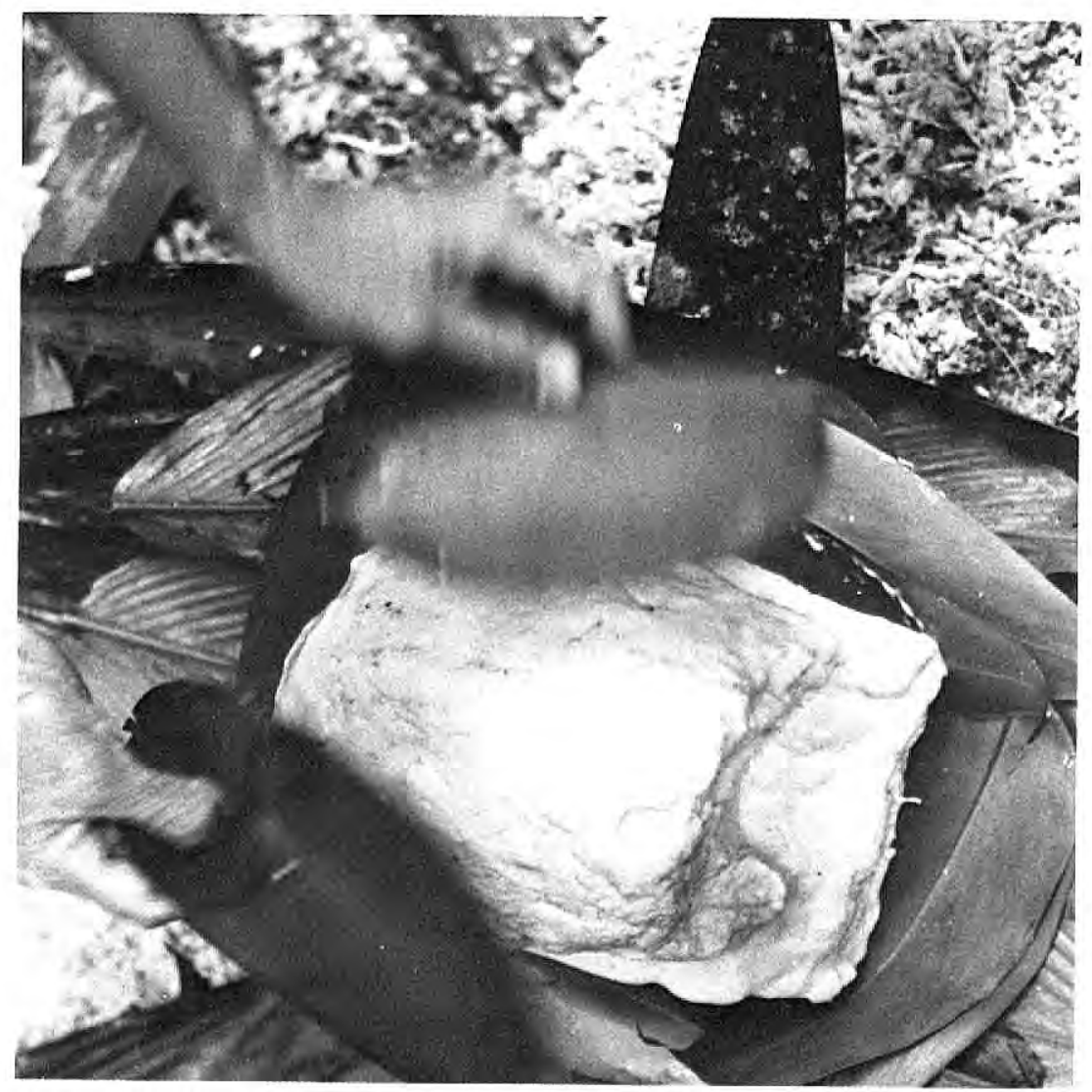

Figure 13. Wrapping sago for storage (Sanio-Hiowe). 
Pearl sago production is undertaken entirely by women, and is done in a bakehouse owned by one of the village women (figure 14a). Pearl sago preparation usually involves cooperative labor (gotong royong) wherein all the village women assist in processing a trunk harvested by a particular farmer, on behalf of his family. The group, in turn, helps another family, and so forth. First, a suitable quantity of wet sago is taken from the trampling platform to the bakehouse, where it is mixed with rice bran and grated coconut (figure 14b). The mixture is left overnight, either in a stone jar or a tin can before being further prepared. Overnight standing is an important part of the production process as it gives sufficient time for the action of certain microorganisms, yeasts and lactobacilli to impart to the mixture a slightly acidic flavor and to introduce carbon dioxide. In this there are striking similarities with the microbial processes involved in the production of old fashioned sourdoughs, made for many millennia from cereal flour in northern Asia and Europe.

The moist mixture is then tipped from its container onto a pandanus leaf mat and thoroughly mixed by two women, who, seated

Figure 14. Stages in Melanau pearl sago manufacture.

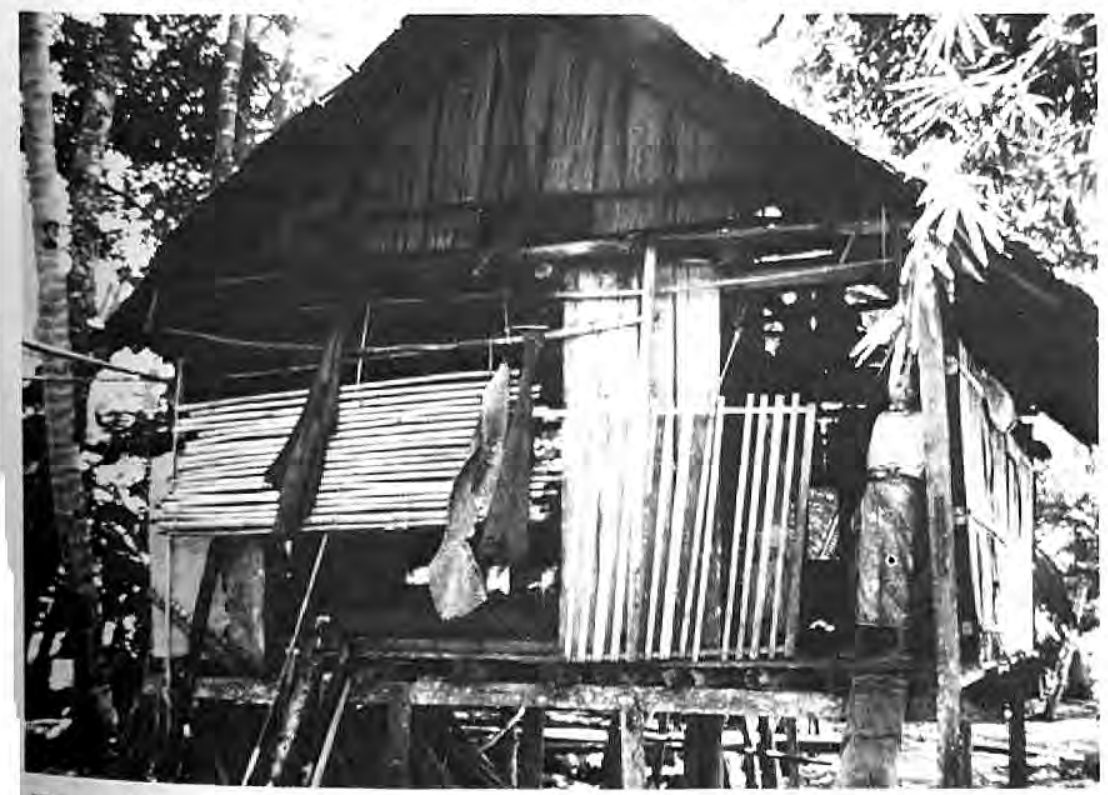

Figure 14a. Bakehouse where pearl sago is made. 
opposite each other, alternately lift up their side of the mat and rhythmically shake the mixture to and fro. Sometimes, one woman alone does this. During this stage of the process the mixture forms into small balls, the formation of which is sometimes assisted by the addition of dry sago flour (figure 14c).

Next, the material is transferred to a circular sieving basket, woven from bamboo, and suspended from the roof. Vigorous sieving for some 15 minutes by a third woman separates the small balls, about the size of a green pea, which remain in the basket, from the unformed material which falls through, to be returned to the mat for more shaking (figures $14 \mathrm{~d}$ and $14 \mathrm{e}$ ).

The still moist, grayish brown balls, colored by the addition of rice bran, are next spread evenly, in a layer about $1.5 \mathrm{~cm}$ deep,

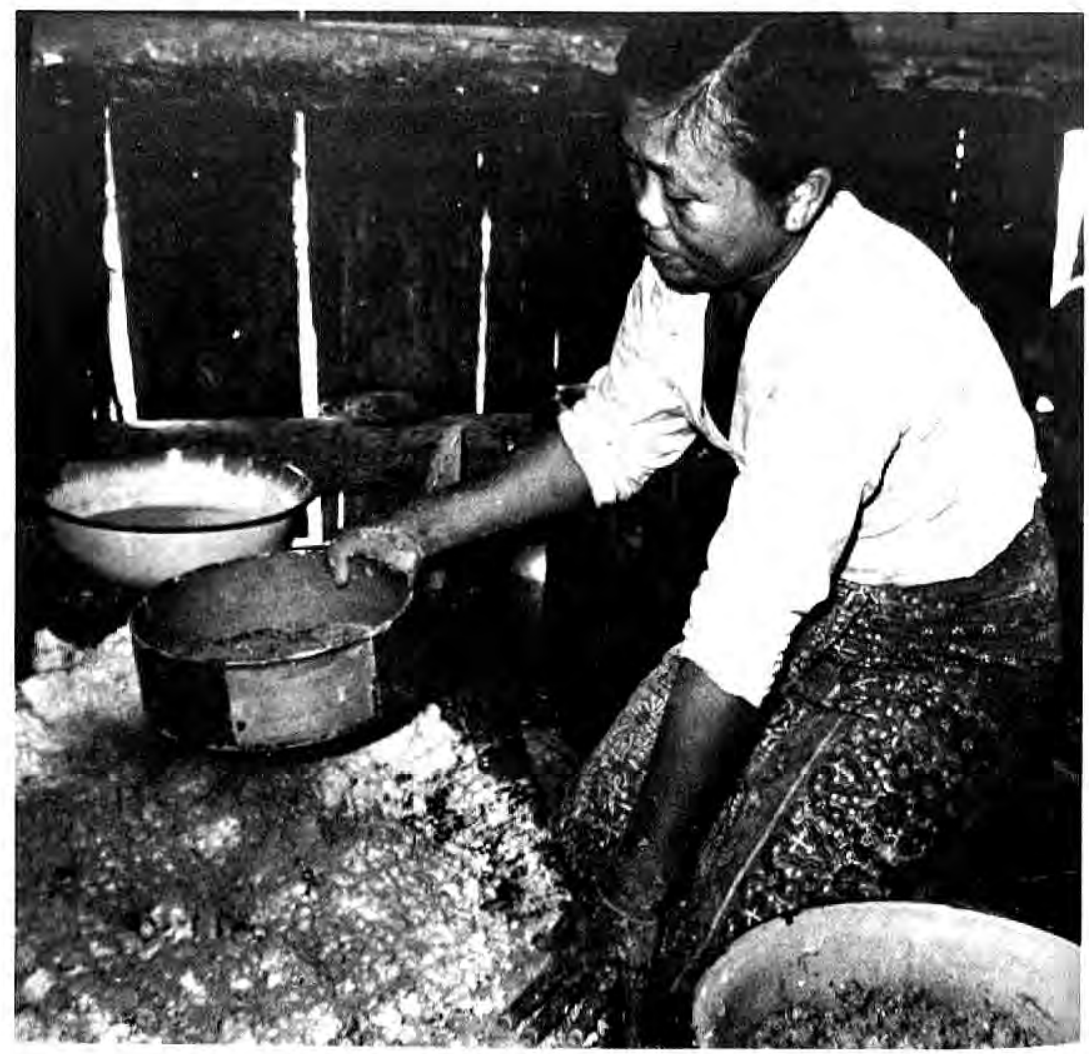

Figure 14b. Mixing sago flour, rice bran, and grated coconut is the first step in making pearl sago. 
over the surface of the clay hearth (figure 14f). The hearth is about $2 \mathrm{~m}$ long, by $1 \mathrm{~m}$ wide and has four tunnels underneath into which logs are fed. The baking surface is surrounded by a $2 \mathrm{~cm}$ rim. The baking process, which must be skillfully performed, is supervised by a fourth, older woman, who constantly stirs the balls with either a palm fiber brush or a stick with rags tied to the end, to ensure even baking (figure $14 \mathrm{~g}$ ). She also tends the fire to maintain the constant, gentle heat required for the process. During baking, which lasts for about 20-30 minutes, the outside of the pearls takes on a darkish brown, dextrinized color. Those which blacken prematurely are removed.

Sago biscuit is also baked when pearl is being produced. Before the mixture is formed into pellets some is removed from the mat and packed into a small flat can, such as a discarded British-style tobacco tin (figure 14h). The can is then thrust into the fire to bake the contents.

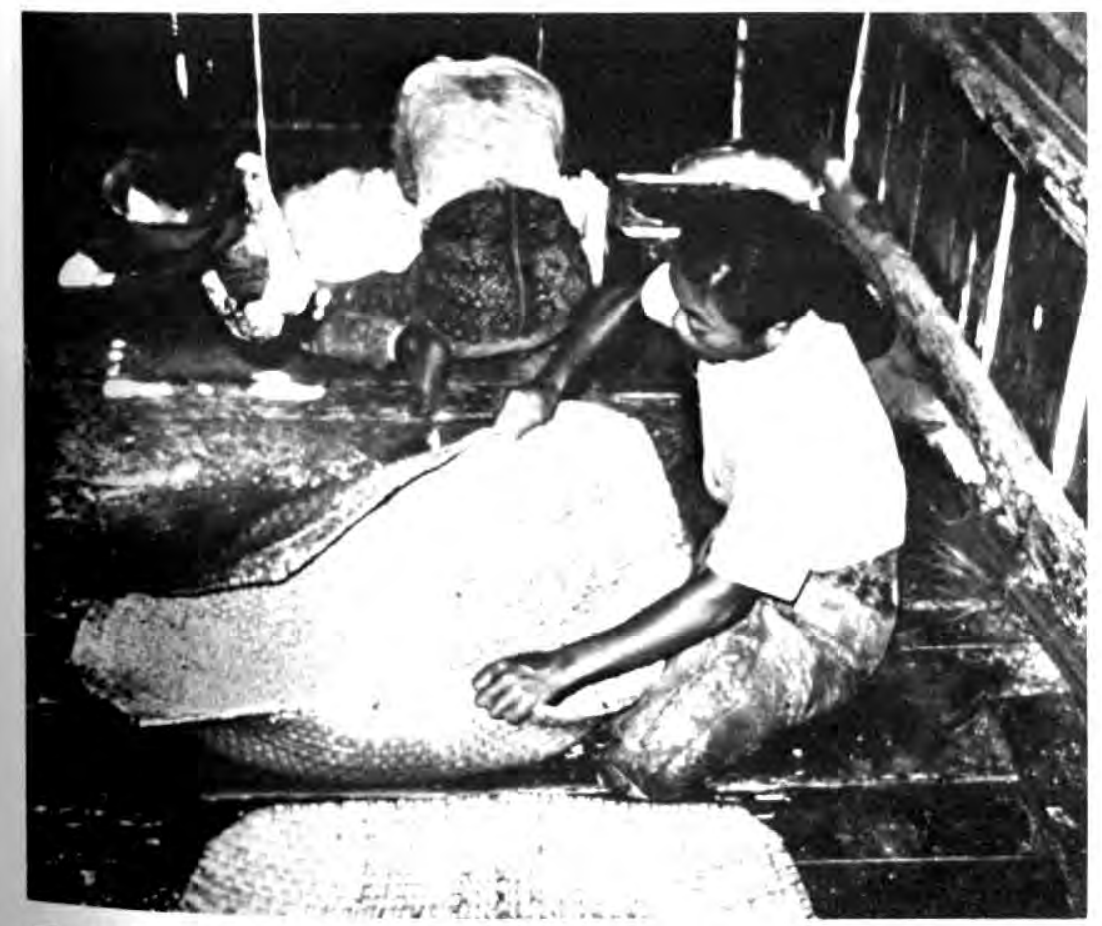

Figure 14c. Next the ingredients are mixed and formed into small, crude balls. 


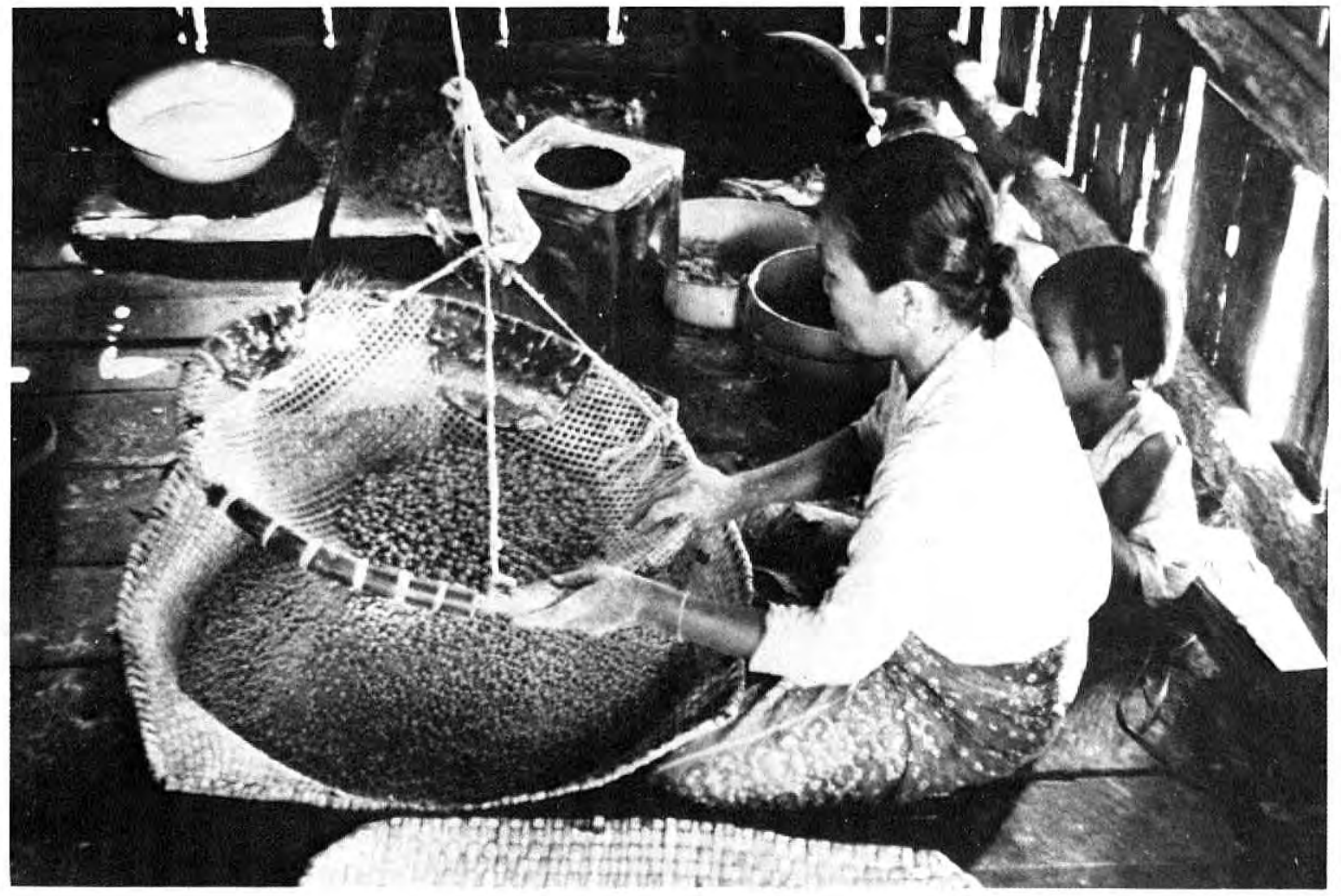

Figure 14d. The balls are then sieved to form well-rounded pellets. 


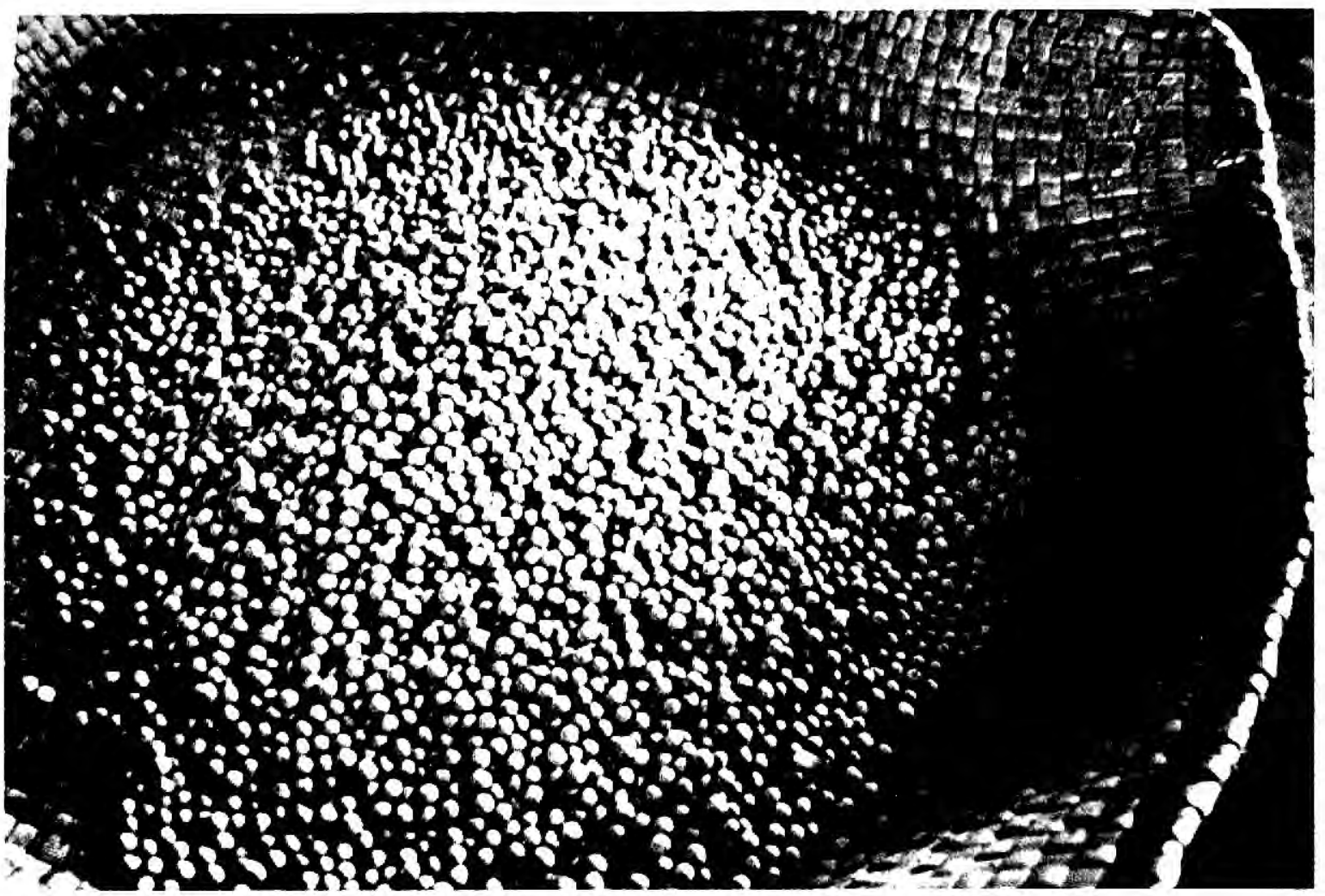

Figure 14e. Finally the pellets are ready for baking. 


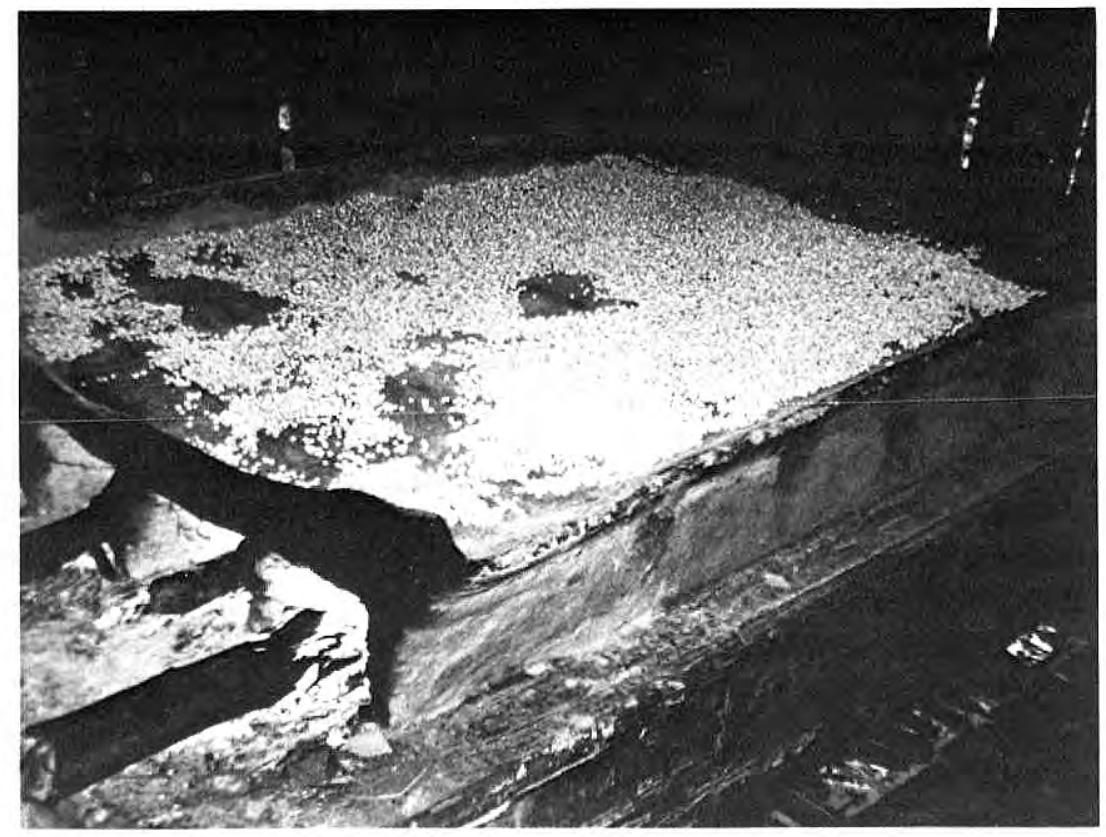

Figure 14f. They are spread evenly on the hearth . . .

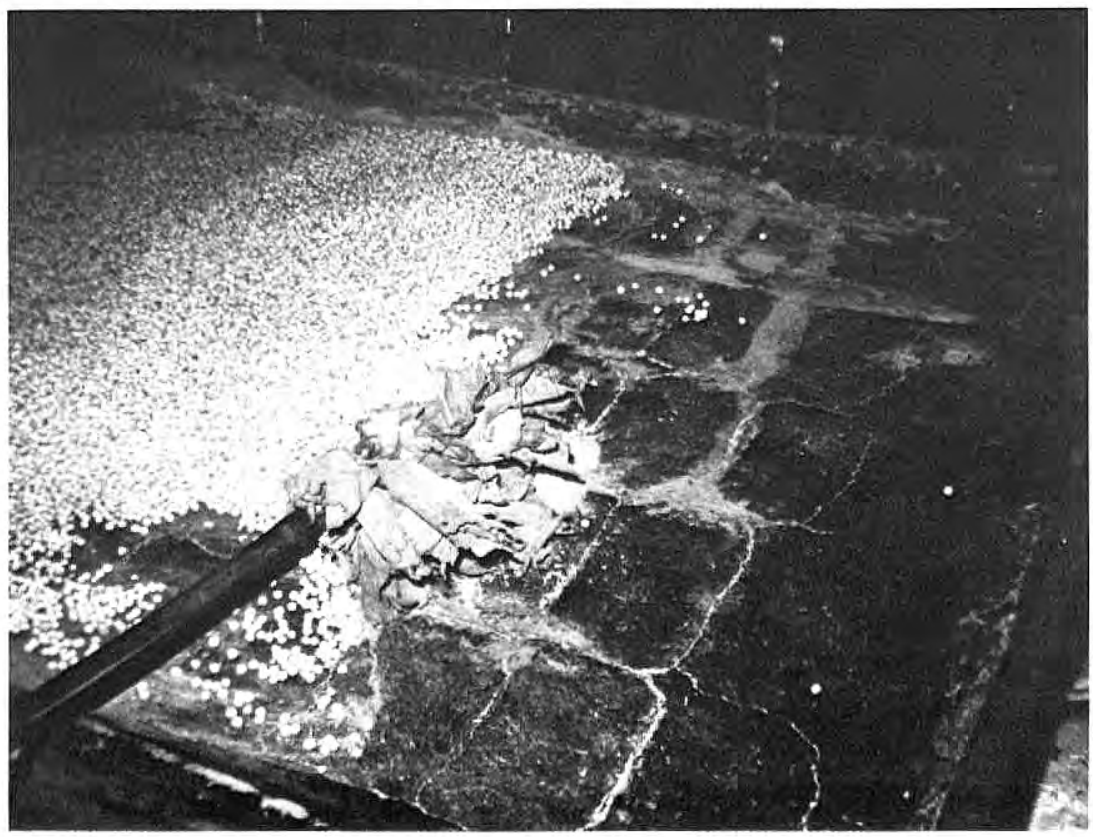

Figure $14 \mathrm{~g} . \ldots$ and stirred to ensure even baking. 


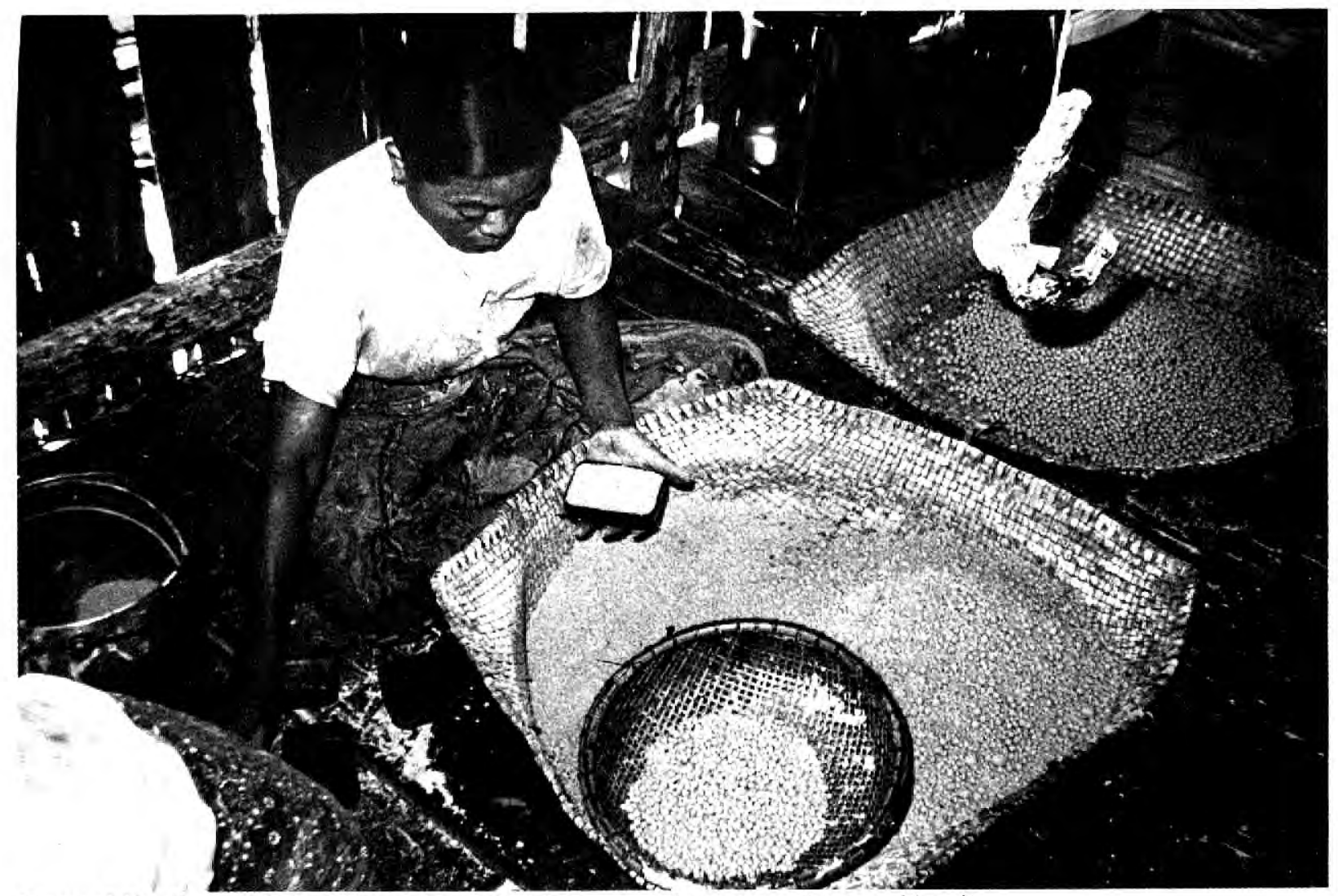

Figure $14 \mathrm{~h}$. Some of the mixture is packed into a small can to make sago biscuit. 
The pearl-making process reduces the moisture content of sago to an extremely low 1-2 percent. As soon as baking is complete the pearls are packed and sealed in tins. This process is ideal when sago must be preserved for extended periods, and it was the high quality of pearl sago which attracted ancient seafarers to this material as a staple food for long ocean voyages.

\section{Cooking}

The methods traditionally used to cook palm stem starch are also remarkably similar throughout the tropical world. Sago is commonly combined with boiling water to produce a thick mush. Small amounts of sago flour, together with water, leafy greens, and perhaps meat as well may be combined to make a soup or stew. In the absence of pottery, sago meal may be either roasted in bamboo tubes, cooked in a simple leaf wrapping, or roasted as cakes in or over an open fire. Moist sago flour may be pressed into a flat cake and baked on a griddle of stone, earthenware, or metal. Rather than attempting to produce a comprehensive sago recipe book by summarizing cooking methods from all the cultures being surveyed, it may be more useful to describe in detail a few sago cuisines representative of different areas.

Adriani and Kruyt (1951:205-206) give a comprehensive description of the many ways in which the Toradja people of Central Sulawesi prepare sago for eating:

Sago is eaten prepared in different ways. In the first place as porridge. In an earthen dish or calabash shell some flour is mixed with cold water, after which boiling water is poured over it. If the porridge does not turn out right, so that it will not set, then one speaks of doei ware, 'porridge cut in two.' This ropy porridge is wrapped around two little sticks into clumps; these are put into the mouth with a spoon of pisang leaf. By pouring some meat or fish liquid over the porridge this bland dish is given somewhat more flavor.

The wet sago is sometimes cooked in bamboo or tree bark, so that it remains slimy and is eaten as porridge.

Another manner of preparation is to cook the still wet sago in a bamboo, with a stalk of bomba or some other plant stuck in the middle. When the sago has stuck to the stalk, the latter is pulled out, and the sago roasted further by the fire.

Still another preparation is to cook the sago in steam. . . . The sago, packed in leaves, is then placed in the pot on a layer of maize cobs, in 
such a way that the water does not come up to the sago; when the water boils, the sago is cooked in the steam.

Sometimes . . . sago is stuck around a little slat or plant stalk or wrapped in leaves and then placed in the hot ashes; through this it becomes hardened and puffy. The flour is also sometimes wrapped in a sago leaf that is fastened with a bamboo pin or with a little piece of palm-leaf rib and is roasted over the fire. . . Packets in leaves are also made of the flour and cooked on a little rack above the fire.

Finally sago is also eaten baked. For this it is shaken into joints of Bambusa longinodis and baked by the fire. When the bamboo has split, the sago comes out of it as a bar; this is broken into pieces and distributed among the people. Or it is crumbled into a frying pan standing on the fire and pressed down into it with a smaller pan. Thus a kind of pancake is formed. . . . For baking sago, earthen forms are also used: these are rectangular pans with grooves into which the sago flour is sprinkled after the form has been heated in the fire; then the form is covered with leaves until the contents are done. The sago comes out like a slice of bread. Baked sago is usually eaten soaked in one or another sauce.

Malinowski did his early fieldwork on Mailu Island off the southeast coast of Papua New Guinea. There sago was of less importance as a food than bananas and taro; nonetheless he records seven ways to prepare sago (1915:550-551): raw; boiled in a porridge with coconut milk and brine; sago dumplings boiled in coconut milk and brine; sago with a piece of meat wrapped in a leaf and boiled; baked in an open fire wrapped in leaves; scraped coconut and sago formed into a ball and boiled; and baked on a hot stone. The Mailu cuisine reflects the availability of pots, in that boiling is prominent.

Among the Sanio-Hiowe of Papua New Guinea (Townsend 1969:33-35), pottery is absent and metal cooking pots are only beginning to be available by trade; this fact is reflected in the cooking of sago. Most sago is wrapped in leaves and roasted on embers. When unwrapped after cooking, the bar-shaped individual serving is browned and crisp on the outside, has a rubbery layer just beneath this, and is dry and crumbly in the center. If a larger quantity of sago is to be cooked in a leaf-wrapped packet, hot stones may be wrapped in with the sago. Game or fish are cooked with hot stones on a layer of sago and edible ferns. The Sanio-Hiowe also make a sago pudding or porridge, especially as a feast food whenever pork is eaten. The pudding is also made for 
feeding to piglets. The sago flour is placed in a vessel made of folded palm crown-shaft material and mixed with a small amount of cold water. Then boiling water, heated in another such vessel by dropping in hot stones, is added to the starch mixture while it is stirred vigorously with a pair of smooth, slender, hard palm wood sticks. The final ratio of sago to water is about three to one, making a viscous gray or white mass. The juices of a few otherwise inedible fruits may be added. These include species of Ficus, Citrus, and Garcinia.

The Guarani of South America cook sun-dried sago flour by packing it into a bamboo tube and roasting it in embers for 5 to 10 minutes. The roasted mass is then removed from the tube, shaped into small cakes, which are then placed uncovered in the fire to roast further. Sago flour is also added to soups (Henry 1964:163). Métraux (1948:80-81) notes that the Guaraní used to roast dried sago flour in a pan, in the same way that manioc flour is now prepared. Cook (1907:60) recorded that the Bororó people of Mato Grosso, Brazil, prepare sago from two to three different palms (which he neither identified, nor named in the vernacular). The sago is made into a bread and used in a soup with buritl (Mauritia vinifera) fruit.

\section{Secondary Food Products}

Secondary foodstuffs derived from sago-producing palms include sap, palm heart or cabbage, and sago grubs. Arenga pinnata and Caryota urens produce inflorescences which are tapped for sap which may be made into sugar or a fermented drink. Some of the palm genera discussed here produce edible fruits; of particular dietary significance are the fruits of Mauritia flexuosa, Manicaria saccifera and Arecastrum romanzoffianum of the New World.

The terminal shoot, palm heart, or palm cabbage is often exploited as an adjunct of sago processing. Since the palm has been felled anyway, the shoot is available to be eaten as a raw or cooked vegetable. However, immature palms may also be cut for their terminal shoot. In the case of dense stands of Metroxylon this practice may have the effect of thinning the grove and increasing productivity. Most of the available information concerns Metroxylon, but extensive use of palm cabbage is also described for Arecastrum (Clastres 1972:156; Métraux and Baldus 1948: 436), Caryota and Arenga (Fernandez and Lynch 1972:305) and 
Mauritia (Heinen and Ruddle 1974:120). In areas where the bush knife (machete, or bolo) has been recently introduced, palm cabbage becomes much more accessible, as observed by Townsend for Metroxylon of the thorny varieties in Papua New Guinea. Fernandez and Lynch (1972:304) also noted that when the knife replaced the stone axe, palm cabbage, called $u b u d$, became accessible to women and children instead of to men only, leading to new problems of resource management for the Tasaday.

Another secondary food product of the palm felled for starch is a salt ash prepared by burning the bases of Metroxylon leaf midribs (Townsend et al., 1973). The discarded washed sago pith, depleted of most of its starch, also provides feed for pigs and poultry, whether it is marketed as such or the household animals merely forage in the sago-working area. In Papua New Guinea feral pigs foraging in sago refuse may be trapped or hunted from a blind.

The most significant secondary food products derived from the various starch-yielding palms are sago grubs, larvae of mostly unidentified species of beetles. When the palm is felled and the pith exposed the beetle lays its eggs, which develop into fat, white larvae. As the log rots and is tunnelled by the feeding larvae, it can easily be broken apart and the larvae picked out. The "cultivation" of grubs presents interesting problems of resource management in the allocation of palms to starch production or grub production. The Sanio-Hiowe of Papua New Guinea (Townsend 1969:54-55) eat the adult sago beetle (une) and larvae in two named stages of development. Their use of grubs has two aspects: grubs obtained for the everyday diet and grubs produced in anticipation of a feast. The grubs eaten in small quantities in the everyday diet are those the women collect from the unworked portions of palms they have cut a month or two earlier. The sections of the Metroxylon palm nearest the ground and just below the crown are lowest in yield and are not utilized for starch production. A month or two before a feast men cut Metroxylon specifically for grub production and notch the logs so that the beetles can readily deposit their eggs. The palms selected are of a low-yielding variety called yapay or asaye nau, 'grub sago.' Thus in each case, the Sanio-Hiowe are allowing the grubs to concentrate and convert sago starch into fat and protein, a very efficient way of exploiting the lowest-yielding sago. 
In other New Guinea societies similar use is made of sago grubs, depending on the relative abundance of sago. ${ }^{2}$ Mead (1970: 41) contrasts the adventitious collection of grubs by the Arapesh from "any rotting sago trunk" with the purposeful felling and covering of palms, to accumulate large quantities of grubs to be smoked for feasts, which is practiced by the people living between the Keram and Yuat rivers (tributaries of the lower Sepik). Also in the Sepik region, the Gadio Enga work only the midsection of each Metroxylon trunk for sago starch. The lower section is chopped up for pig food and the section below the crown reserved for grub colonization by a cerambycid beetle (Dornstreich 1973: 164, 208, 213-214).

Sago grubs have an important ceremonial role for the Asmat of the south coast of Irian Jaya. In the consecration ritual for a rebuilt men's house, large numbers of "the larvae of the capricorn beetle" (Gerbrands 1967:25) are placed in a cylinder made of palm leaves. The cylinder represents the sago palm, the tree of life. At the conclusion of a dance the cylinder is chopped open and the larvae flow out. They are then shared out as the feast food. The Asmat management of sago resources for starch and grubs reflects their change from seminomadism to settlement in large permanent villages. Sago palms near the village are used for starch production, whereas more distant stands are designated for producing grubs for ritual use (Amelsvoort 1964:87).

Collection of sago grubs is reported from several Southeast Asian areas. The Tasaday leave a substantial portion of the trunks of Caryota and Arenga from which they have prepared sago. They return to collect beetle grubs from the rotting trunks months later (Fernandez and Lynch 1972:306). The Melanau of Sarawak highly prize grubs taken from sago stumps. They eat them live with salt, boiled, or fried. Traditional Melanau marriage feasts include chicken boiled with sago shoots, as well as sago grubs (Jamuh and Harrisson 1969:211, 218). Sago grubs are also considered a delicacy on Siberut in the Mentawai Islands (Nooy-Palm 1968:169).

The most extensive reported dependence on grubs is among the Guayaki of eastern Paraguay. Their nomadic pattern is largely based on gathering the larvae of the coleoptera which feed on the pindo palm (Arecastrum romanzoffianum). The band migrates from grove to grove, exploiting the starch and terminal shoot of 
the palms and preparing trunks for the later harvest of larvae ( $g u$ $c h u$ ). Although the collection of larvae is not as significant quantitatively as hunting in Guayaki subsistence, it is the necessity to revisit the palm groves for grubs which organizes their nomadic round, according to Clastres (1972:166-167). Elsewhere in South America, felling of palms for grub cultivation has been described for the Nambicuara Indians of northern Mato Grosso, Brazil, who fell burití palms (Mauritia vinifera) so that grubs can invade the starchy pith (Oberg 1953:92). The Warao of the Orinoco Delta exploit the larvae of the palm borer Rhyncophorus palmetum developing in Mauritia flexuosa and in Manicaria saccifera (Heinen and Ruddle 1974:120; Wilbert 1976:280).

\section{Traditional Trade in Sago}

With the exception of the island of New Guinea, there is little available data on traditional trade in sago. Sago from Metroxylon palms has been widely reported as an important item of intertribal trade networks in various regions of Papua New Guinea (Fortune 1932:207; Groves 1972:523-527; Harding 1967:31; Malinowski 1922:377-378; Seligman 1910:96-110; Singh Uberoi 1972:584586). Until recently, the natives of the Port Moresby area exchanged earthenware pots, stone adze-blades, shell arm-rings, and various ornaments for sago and large canoes in which to make the trading voyages (hiri). This trade gave rise to an intensive canoe traffic between the Port Moresby area and the western delta region, and between Geelvinck Bay and the Waropen marshes. Following the disruption of the Second World War, an unsuccessful attempt was made in the Purari area to reorganize this trade by selling sago and copra in European and tribal markets in Port Moresby (Maher 1961:63). 


\section{SAGO AS SUBSISTENCE, COMPLEMENTARY, AND EMERGENCY FOOD}

\section{Subsistence Food}

The present use of cultivated, protected, or wild sago palms for the production of sago as a staple subsistence item appears to be restricted to some ethnic and rural groups of the coastal mountains and swampy lowland areas of Papua New Guinea, parts of Indonesia, the Philippines, Thailand, and Malaysia in the Old World, and to the eastern Orinoco Delta in the New.

Metroxylon is undoubtedly the most important single source of palm stem starch. In Melanesia at least 300,000 people rely on it as their main energy food, and some one million consume it regularly in their diet (Brookfield with Hart 1971:86).

Reports indicate that palms of the genus Metroxylon have been introduced to areas beyond their natural range. According to Barrau (1961:59-60), Metroxylon has been in Samoa since pre-European times, and in Rotuma and Tonga, to which it may have been taken from the Fijian group, "since ancient days." More recently the palm was taken by Germans to Western Samoa, and by both Germans and Japanese to Palau. Metroxylon has diffused westward through parts of Indonesia to West Malaysia, where it is cultivated for commercial purposes, although details of the westward diffusion remain to be clarified. Metroxylon cultivation has recently spread to new areas within its natural range; the Mejbrat people of Irian Jaya took up the cultivation of the palm to provide an additional source of food (Elmberg 1955:58). Some ethnic groups producing sago for subsistence are listed in table 2 . The locations of Southeast Asian groups are shown in figure 15. 
TABLE 2. Some Ethnic Groups Producing Sago

\begin{tabular}{|c|c|c|c|c|}
\hline Ethnic Group $^{a}$ & Locality & Palm Utilized & Status & Reference \\
\hline 1. Abelam & East Sepik Dist., PNG & Metroxylon sp. & wild & Lea $1964: 122$ \\
\hline 2. Alfur ${ }^{b}$ & $\begin{array}{l}\text { Interior Seram, Maluku, } \\
\text { Indon. }\end{array}$ & $\begin{array}{l}\text { Metroxylon sp. } \\
\text { Arenga sp. }\end{array}$ & cultivated & $\begin{array}{l}\text { Tauern 1918:102-105 } \\
\text { Jensen 1939:342-343 }\end{array}$ \\
\hline 3. Ambonese & Ambon Is, Maluku, Indon. & Metroxylon sp. & cultivated & Cooley 1962:10, 1967:138 \\
\hline 4. Asmat & South Irian Jaya, Indon. & Metroxylon sp. & wild & Amelsvoort 1964:36-37 \\
\hline 5. Bila-an & Mindanao, Philippines & Corypha umbraculifera & wild? & Gerbrands 1967:29 \\
\hline 6. Bisaya & Southwest Sabah & Metroxylon sp. & $\begin{array}{l}\text { wild and } \\
\text { cultivated }\end{array}$ & Ruddle (field survey) \\
\hline 7. Bororó & Mato Grosso, Brazil & not identified & wild & Cook 1907:60 \\
\hline 8. Dyak & $\begin{array}{l}\text { Karimata Is., Kalimantan, } \\
\text { Indon. }\end{array}$ & Arenga sp. & unknown & Bartlett 1963:208 \\
\hline 9. Elema & Gulf Dist., PNG & Metroxylon sp. & wild? & Rumens 1972:510 \\
\hline 10. Foe (Kutubu) & $\begin{array}{l}\text { Southern Highlands Dist., } \\
\text { PNG }\end{array}$ & Metroxylon sp. & wild? & Williams 1940:152-153 \\
\hline 11. Gadio Enga & East Sepik Dist., PNG & Metroxylon sp. & wild & $\begin{array}{l}\text { Dornstreich 1973:205-218, } \\
331-333\end{array}$ \\
\hline 12. Guayaki & Eastern Paraguay & Arecastrum romanzoffianum & wild & $\begin{array}{l}\text { Clastres 1972:156 } \\
\text { Métraux and Baldus 1948:436 }\end{array}$ \\
\hline 13. Hanunóo & Mindoro, Philippines & Arenga sp. & unknown & Conklin 1957:87 \\
\hline 14. Hiowe (Heve) & East Sepik Dist., PNG & Metroxylon sp. & wild & P. Townsend 1969 \\
\hline 15. Hopoi & Morobe Dist., PNG & Metroxylon sp. & wild? & Streicher 1934:236-237 \\
\hline 16. Kai & Kai Is., Maluku, Indon. & Metroxylon sp. & cultivated? & $\begin{array}{l}\text { Geurtjens 1929:229-231 } \\
\text { Nutz 1959:14-19 }\end{array}$ \\
\hline $\begin{array}{l}\text { 17. Kaingáng } \\
\text { (Guaraní) }\end{array}$ & South Mato Grosso, Brazil & Arecastrum romanzoffianum & wild & Henry $1964: 163$ \\
\hline
\end{tabular}


TABLE 2. (cont.)

\begin{tabular}{|c|c|c|c|c|}
\hline Ethnic Group ${ }^{a}$ & Locality & Palm Utilized & Status & Reference \\
\hline 18. Keraki & Western Dist., PNG & Metroxylon sp. & $\begin{array}{l}\text { wild and } \\
\text { cultivated }\end{array}$ & Williams 1936:422-424 \\
\hline 19. Kimam & Dolak Is., Irian Jaya & Metroxylon sp. & wild & Serpenti 1965:46-48 \\
\hline 20. Kiwai & Western Dist., PNG & Metroxylon sp. & cultivated & Landtman 1927:101 \\
\hline 21. Kwoma & East Sepik Dist., PNG & Metroxylon sp. & cultivated & $\begin{array}{l}\text { Whiting and Reed } \\
1939: 178-179\end{array}$ \\
\hline 22. Mailu & Central Dist., PNG & Metroxylon sp. & wild? & $\begin{array}{l}\text { Malinowski 1915:550-551, } \\
\text { 598-599 }\end{array}$ \\
\hline 23. Marind-anim & South Irian Jaya & Metroxylon sp. & wild & Baal 1966:484 \\
\hline 24. Mejbrat & Ajamaru Dist., Irian Jaya & Metroxylon sp. & cultivated & Elmberg 1955:58 \\
\hline 25. Melanau & Oya River, Sarawak & Metroxylon sp. & cultivated & Morris 1953:11 \\
\hline 26. Mentawaians & $\begin{array}{l}\text { Mentawai Is., W. Sumatra, } \\
\text { Indon. }\end{array}$ & Metroxylon sp.? & cultivated & Nooy-Palm 1968:169 \\
\hline 27. Me'udana & $\begin{array}{l}\text { Normanby Is., Milne } \\
\text { Bay Dist., PNG }\end{array}$ & Metroxylon sp. & $\begin{array}{l}\text { wild and } \\
\text { cultivated }\end{array}$ & Schlesier 1965:6-15 \\
\hline 28. Mimika & South Irian Jaya & Metroxylon sp. & $\begin{array}{l}\text { wild and } \\
\text { cultivated }\end{array}$ & Pouwer 1955:35-37 \\
\hline $\begin{array}{l}\text { 29. Mountain } \\
\text { Arapesh }\end{array}$ & East Sepik Dist., PNG & not identified & unknown & Mead 1970:42, 143 \\
\hline 30. Nimboran & Nimboran, Irian Jaya & Metroxylon sp. & wild & Kouwenhoven 1956:15-16 \\
\hline 31. Nuaulu & $\begin{array}{l}\text { South Seram, Maluku, } \\
\text { Indon. }\end{array}$ & Metroxylon sp. & $\begin{array}{l}\text { wild and } \\
\text { cultivated }\end{array}$ & Ellen 1975:140-141 \\
\hline 32. Orokaiva & Northern Dist., PNG & Metroxylon sp. & wild & Williams 1930:58-60 \\
\hline 33. Punan & Rejang and Baram Valleys, & Eugeissona utilis & wild & Beccari 1904:307 \\
\hline
\end{tabular}




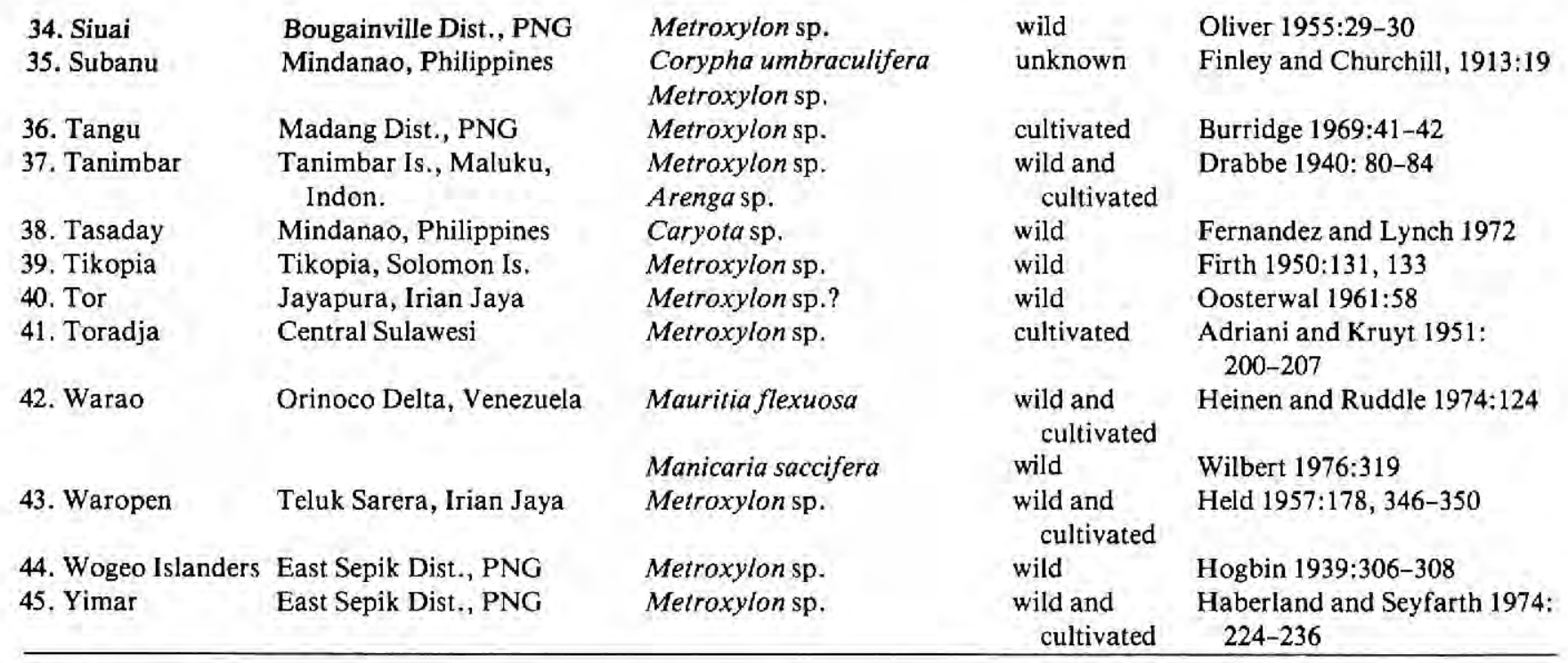

Notes:

a Locations of Southeast Asian groups are shown by number in figure 15 .

$b$ "Alfur" includes various groups, for example, the Wemale. It is not a good term for these people, but Tauern uses it as a general term for the interior peoples of Seram and does not give more exact provenience for his data. 


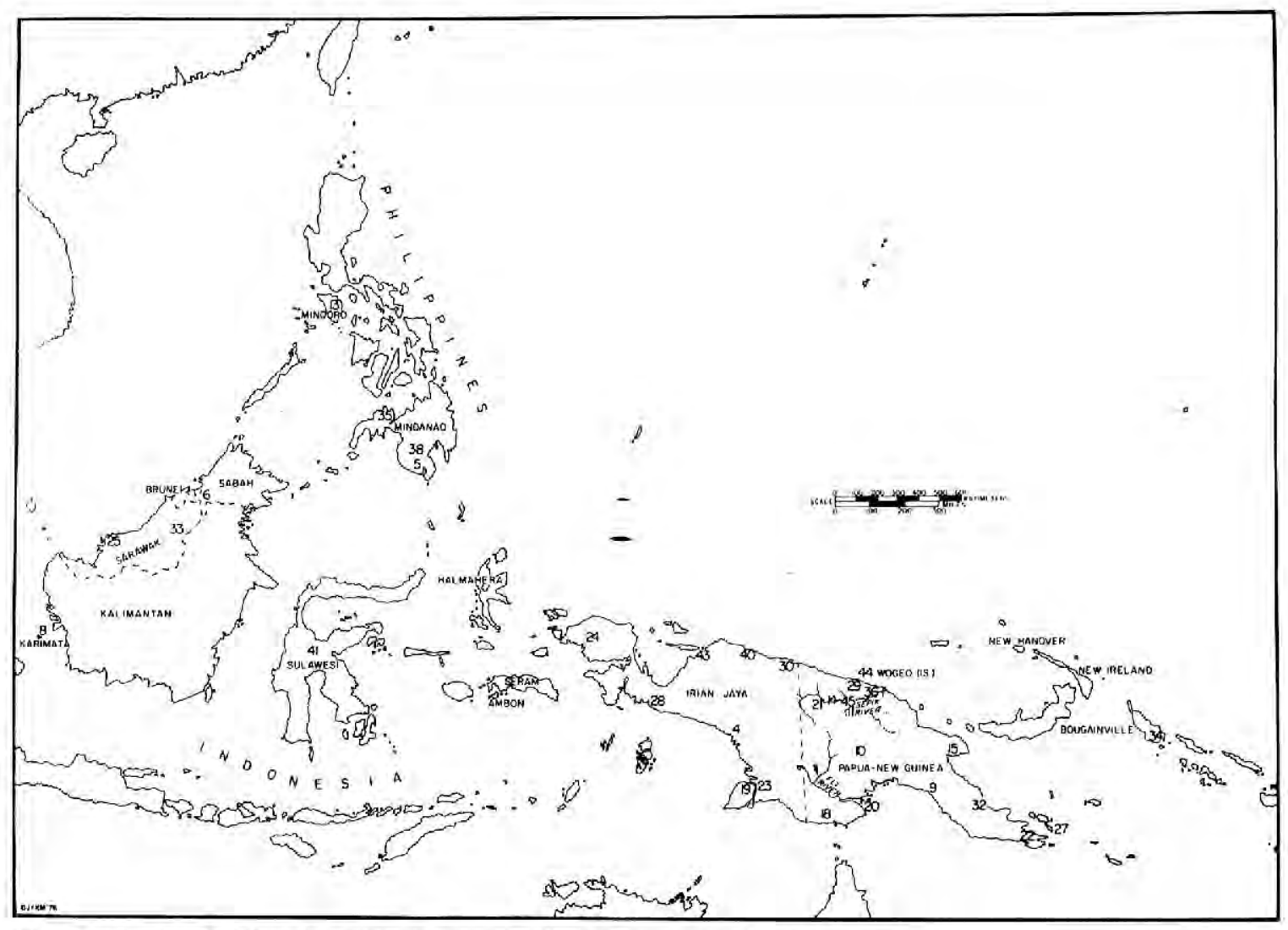

Figure 15. Insular Southeast Asia: some ethnic groups producing sago. 
On the island of New Guinea, more than 100,000 Metroxylon sago-eaters annually produce an estimated $115,000 \mathrm{MT}$ of sago (McArthur 1972:442) and live principally along the Sepik, Fly, and Idenburg rivers, and in the deltaic parts of the lowlands such as those around Merauke and Waropen, and in the Purari Delta.

The most extensive and continuous tracts of Metroxylon occur in the Sepik valley and along the Sepik Gulf of northwestern Papua New Guinea, and along the Gulf of Papua, from the Fly Delta in the west, embracing the lower courses of the Purari and Turama rivers, to the Inauafunga in the east. Elsewhere in Papua New Guinea the distribution of Metroxylon palms is more fragmented: the lower courses of the south coastal rivers; the lower Opi and Mambare rivers of the north coast, for example; and the coasts of the Admiralty Islands, northern New Britain and southwestern Bougainville (Paijmans 1975:11-12, 17-18). In the Kerema-Vailala area of the Gulf District, where sago is a major component of the diet of the Elema people, palms grow or are grown in swampy depressions which separate individual beach ridges and swampy plains. In the mangrove-nipa palm zone, which extends from Bell Point to the eastern edge of the Purari Delta, and where cultivable land is extremely limited, the population subsists mostly on a diet of sago and crabs. The inhabitants of scattered settlements in alluvial swamps away from the beach ridges and beach plains subsist on sago and the products from gardens cultivated on narrow levees and terraces (Rumens 1972: 510). Metroxylon sago was also an important foodstuff on the Vanikolo and Ndende islands of the Santa Cruz group, Eastern District, Solomon Islands (Graebner 1909:99; Speiser 1916:184), and in Fiji (Guppy 1906:vol. 2:413). ${ }^{1}$

Metroxylon palms are also cultivated on the slopes of the Southern Highlands, Papua New Guinea, at elevations of $800 \mathrm{~m}$, by groups living around Lake Kutubu and at similar elevations by the inhabitants of the Torricelli Mountains in the West Sepik District (Lea 1972:14). Sago comprises a principal item of the diet in much of the Western and Southern Highlands districts (Blake 1972:1191; McAlpine 1972:1089). In the New Ireland District it is a staple food on New Hanover island, and an important subsidiary on Djaul, New Ireland, and the islands off the east coast (Reynolds 1972b:857).

In Indonesia sago has a very long historical record as a food. It 
was first described by Marco Polo in the thirteenth century as one of the typical food items in western Sumatra (Polo 1930:279-280). More than three centuries later it was again mentioned along with millet and rice as a common food in Sumatra (Purchas 1617:695), and a monumental description was made 300 years ago by Rumphius in his 6 volume work, Herbarium Amboinense (Merrill and Robinson 1917). Over much of Indonesia, in more recent times, the cultivation of rice, maize, and cassava has gradually replaced sago. In western Java, for example, sago palms were reportedly cultivated at the beginning of this century, a trait which has now disappeared (Alkema and Bezemer 1927:362). Nevertheless, sago remains important as a subsistence foodstuff in many parts of that country: on the Mentawai Islands off the west coast of Sumatra (Nooy-Palm 1968:169), on the Bangka and Billiton islands, in the Riau Archipelago and the Lingga Islands, which form part of Riau province, in parts of eastern Sumatra, Bali, and Lombok (Republic of Singapore n.d.), Kalimantan (Republic of Indonesia n.d.a.), Maluku (Burhamzah 1970:34), Irian Jaya (Manning and Garnaut 1972:38; Garnaut and Manning 1973:56), and in areas of North Sulawesi (Boediono, 1972:68).

Within Indonesia, Maluku is the area most strongly associated with dependence on sago for subsistence, though even here it is not the staple on every island group. In the north, sago is the staple in much of Halmahera, Sulu, Buru, Seram, and Ambon (Nutz 1959:18; LeBar 1972:117, 120). Even in areas where sago remains the carbohydrate staple, rice and cassava are of increasing importance, for example, the traditional agricultural village of Allang on Ambon Island (Cooley 1962:10, 1967:138). In southern Maluku, sago is the major staple in the low, swampy Aru Islands (LeBar 1972:115), it is important on Kisar, Roma, Babar, and Damar (LeBar 1972:110), and it supplements the tubers, maize and rice produced by shifting cultivation on the Kai Islands (Nutz 1959:13; Geurtjens 1921:229-231) and on Wetar (Josselin de Jong 1947:30).

In Malaysia sago is extracted for both subsistence and commercial purposes in Sarawak and Sabah, and small amounts are produced in West Malaysia. In the mid-1930s, the total area in West Malaysia under Metroxylon palms was estimated at 1416 ha, of which some 88 were located in the state of Johore, and about 240 in Kedah (Grist 1936:300). According to the 1960 Census of Agriculture (Federation of Malaya 1960:79) the compact area under 
sago palms was put at some 1018 ha of which 852 were in the state of Johore. ${ }^{2}$

Metroxylon grows widely throughout Sarawak, but sago production is concentrated in the Mukah, Oya, Dalat, and Matu districts of the Third Division, and the Biladin, Saratok, and Pusa districts of the Second Division. Although widely planted on the extensive tracts of deep freshwater peat-where areas suited to alternative crops are few-the best sago gardens lie on the riverterrace loams.

In Sarawak subsistence production of sago and most of the basic processing of the commercial product is mainly accomplished by various ethnic groups. Of these the most renowned are the Melanau, who inhabit the valleys of the Igan, Oya, Mukah, Balingian, Tatau, and Kemena rivers. The Bisaya, a small group located in the middle Limbang valley, plant sago, as well as wet rice, and rubber. Small, nomadic, nonagricultural groups of $\mathrm{Pu}-$ nan, who inhabit the forests of the upper Rejang and Baram valleys, subsist on wild sago, other items of the native vegetation, and wild game (Jackson 1968:52).

In many parts of Sabah, Metroxylon stem starch is used for both human and animal food, with the greatest concentrations occuring in the Interior and West Coast Residencies, particularly in Beaufort, Kuala Penyu, Papar, Penampang, and Keningau. By contrast, in East Coast Residencies, Tawau and Sandakan, very little sago production is recorded (State of Sabah 1969:8).

In Brunei Metroxylon sago is second to rice as a subsistence item among the ethnic population, with the main production areas located in the Kuala Belait and Tutong districts, and areas of lesser importance in the Temburong District (State of Brunei 1969:44). Production is mostly to satisfy family subsistence needs, but surpluses are sold, particularly in the Kuala Belait market (Lim 1974:145). Small quantities are irregularly exported. Sago refuse is sold to local Chinese and Kadazen (Dusun) pig raisers. Data on Brunei's sago production, as well as those for the majority of other crops, are rather scanty and rudimentary.

Sago produced from Metroxylon is locally important in southern Thailand, from Chumporn Province southward, as a subsistence foodstuff and for pig feed. Before cassava was introduced, sago was more widely used as human food in Thailand (Sanavacharin pers. comm.). Small surpluses are exported. Trade statistics indicate that sago derived from palm stem is produced in the 
People's Republic of China, but we are unable to specify whether or not it is used domestically for subsistence.

Available data do not generally confirm the regular present-day use of genera other than Metroxylon for the production of sago as a staple foodstuff. The localized subsistence use of sago from other genera can be inferred from some older reports: Caryota in the Mishmi ranges of India (Griffith 1850:70); and C. urens and C. umbraculifera from Sri Lanka, where sago was described as " . . . a valuable article of food" (Trimen 1898:325 and 328); $R a$ phia in the Malagasy Republic (Pickering 1879:630); Arenga in India (Graham, cited by Pickering 1879:335); and Corypha by the Bila-an people of southern Mindanao (Cole 1913:83). The same inferences can be made for the New World: Syagrus in Pernambuco, Brazil (Koster 1817:366); Roystonea in the West Indies (Seemann 1856:282); Mauritia in the Amazon (Seemann 1856: 252-253); and Acrocomia (no location given) (Burkill 1935:39). Mauritia is still widely exploited by the Warao Indians of the Orinoco Delta as a dietary staple (Heinen and Ruddle 1974:119).

The Tasaday tribe, a recently discovered preagricultural people inhabiting the forests of southern Mindanao, were newly introduced to the manufacture of sago by an individual of the neighboring Manobo B'lit tribe (figure 16). Among the Tasaday sago derived from Arenga and Caryota (Yen pers. comm.; Fernandez and Lynch 1972:305) has been used since 1966 as an important staple addition to an otherwise fairly spartan diet, despite the fact that an entirely new technology had to be accepted:

When Dafal [the Manobo B'lit] showed the Tasaday how to process natok, or wild-palm pith, he introduced to them a complex knowledge of equipment and behavior. The tools involved are ... the bolo ... a press made of split bamboo and ferns; a trough made of bark (later used to make trays in which the starch is heated), a scoop of the same kind of bark, and wooden mallet-like pounders used to pound and fragment the pith before it is placed in the press. (Fernandez and Lynch 1972:298)

The newly acquired knowledge of sago making has had two important effects on the tribal subsistence system: wild yams formerly provided the main starch base of the diet-these are now much less important; and secondly, the Upland Forest Zone microenvironment (Fernandez and Lynch 1972:305-307), now plays an increased role in the subsistence ecology of the Tasaday. 
Figure 16. Tasaday production, preparation, and use of Caryota sago.

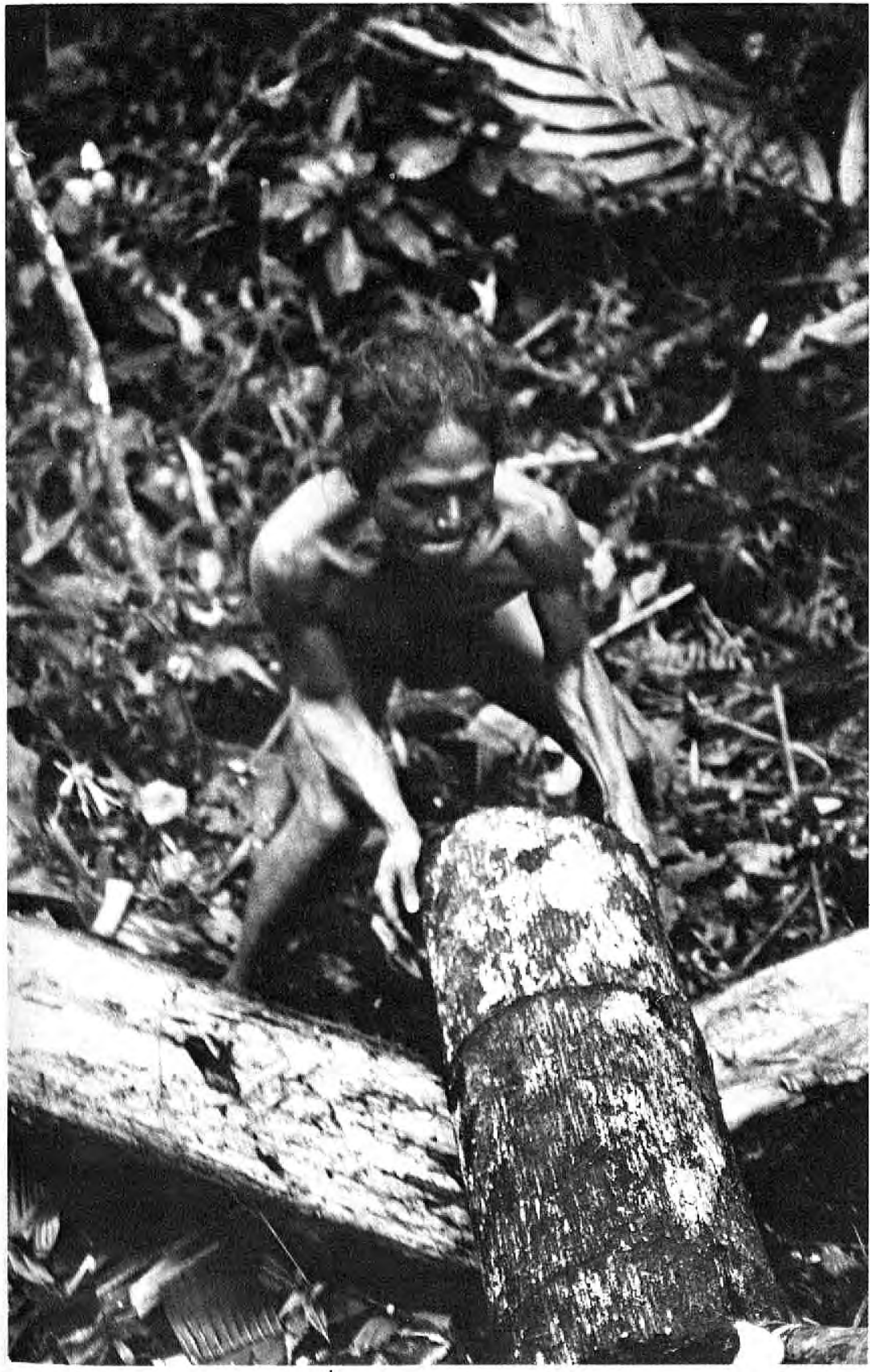

Figure 16a. Positioning a trunk to be split. 


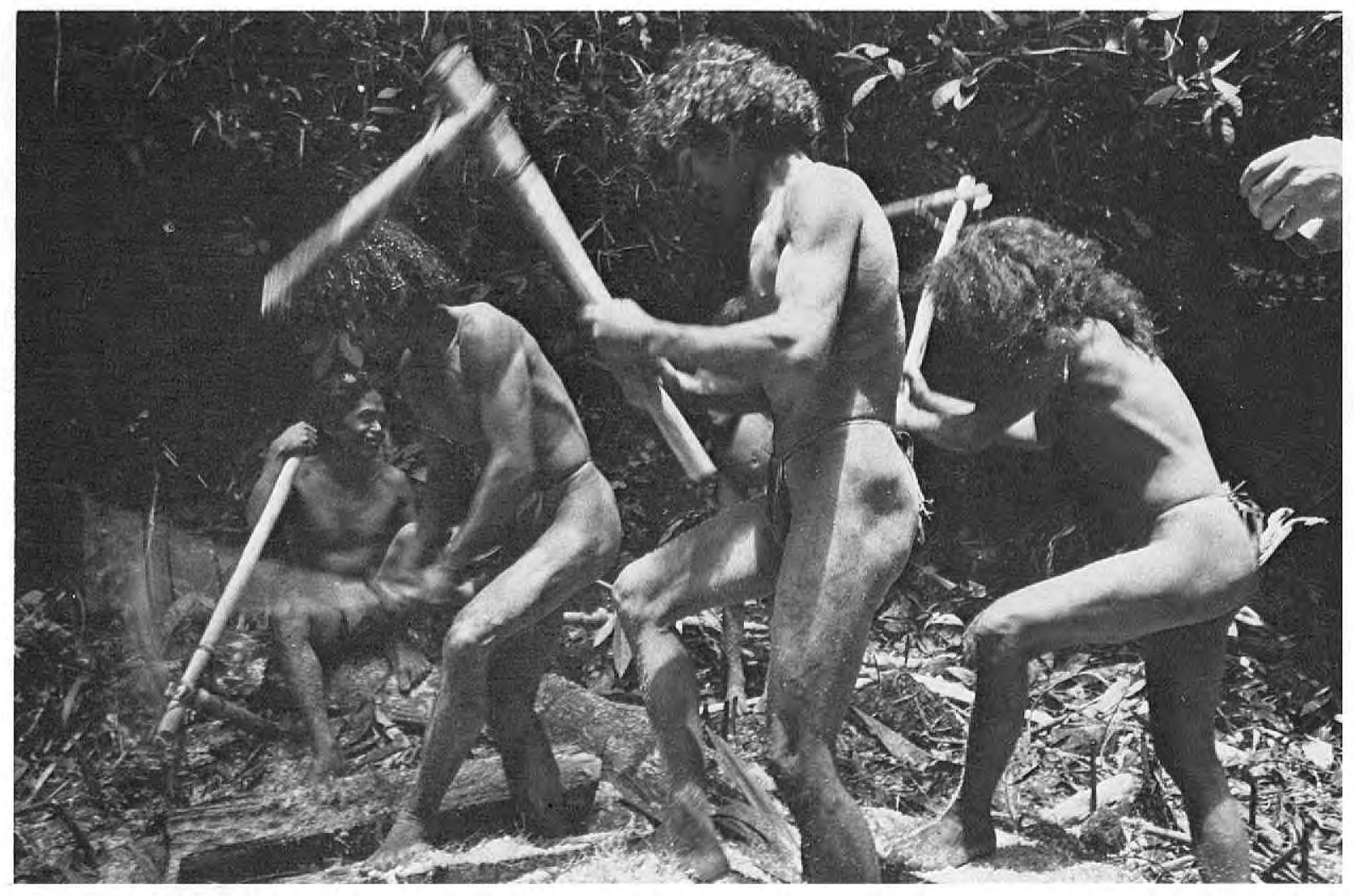

Figure 16b. Pounding the pith. 


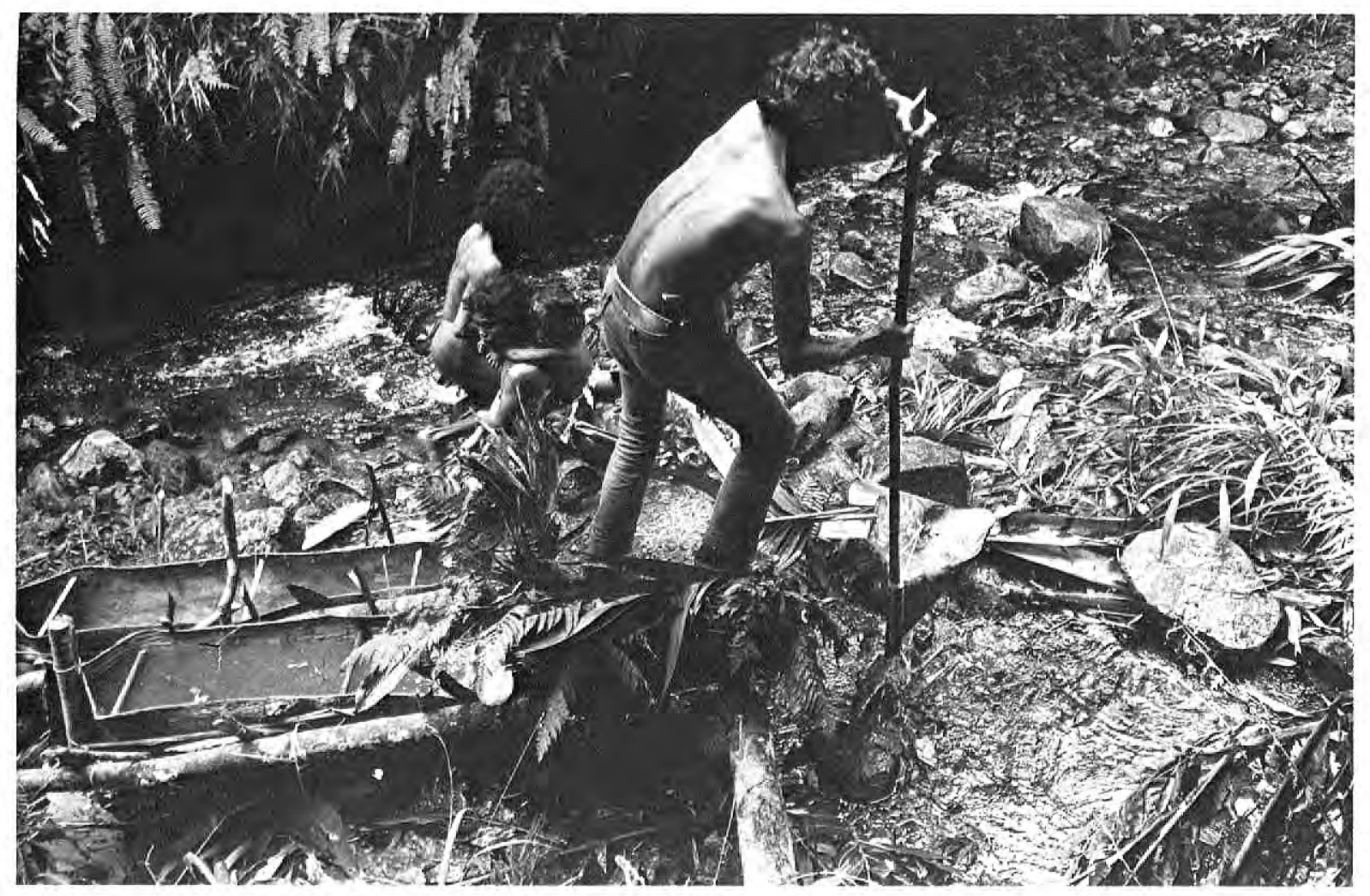

Figure 16c. Scooping water onto the pith. 


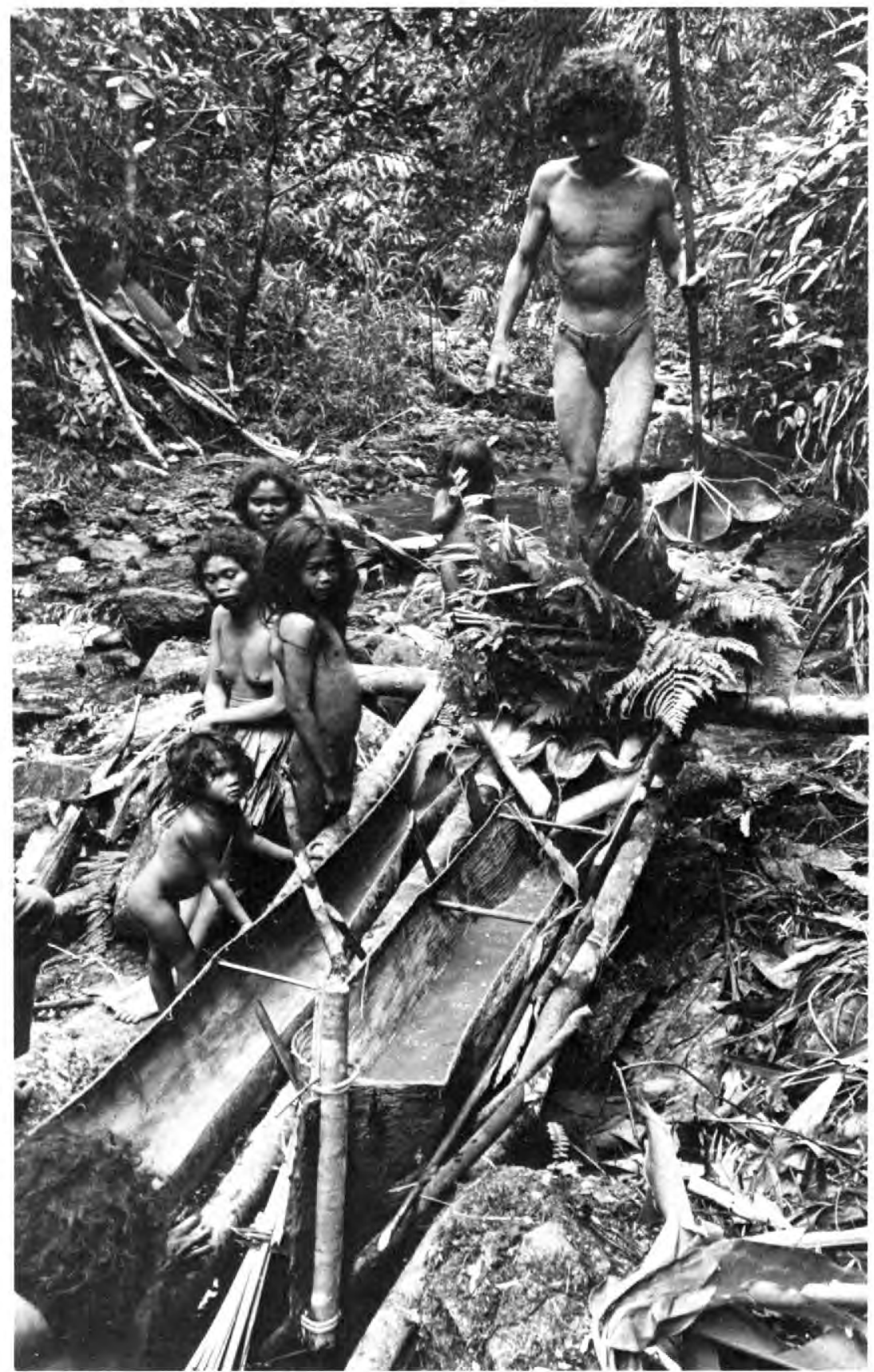

Figure 16d. Trampling to express the starch. 


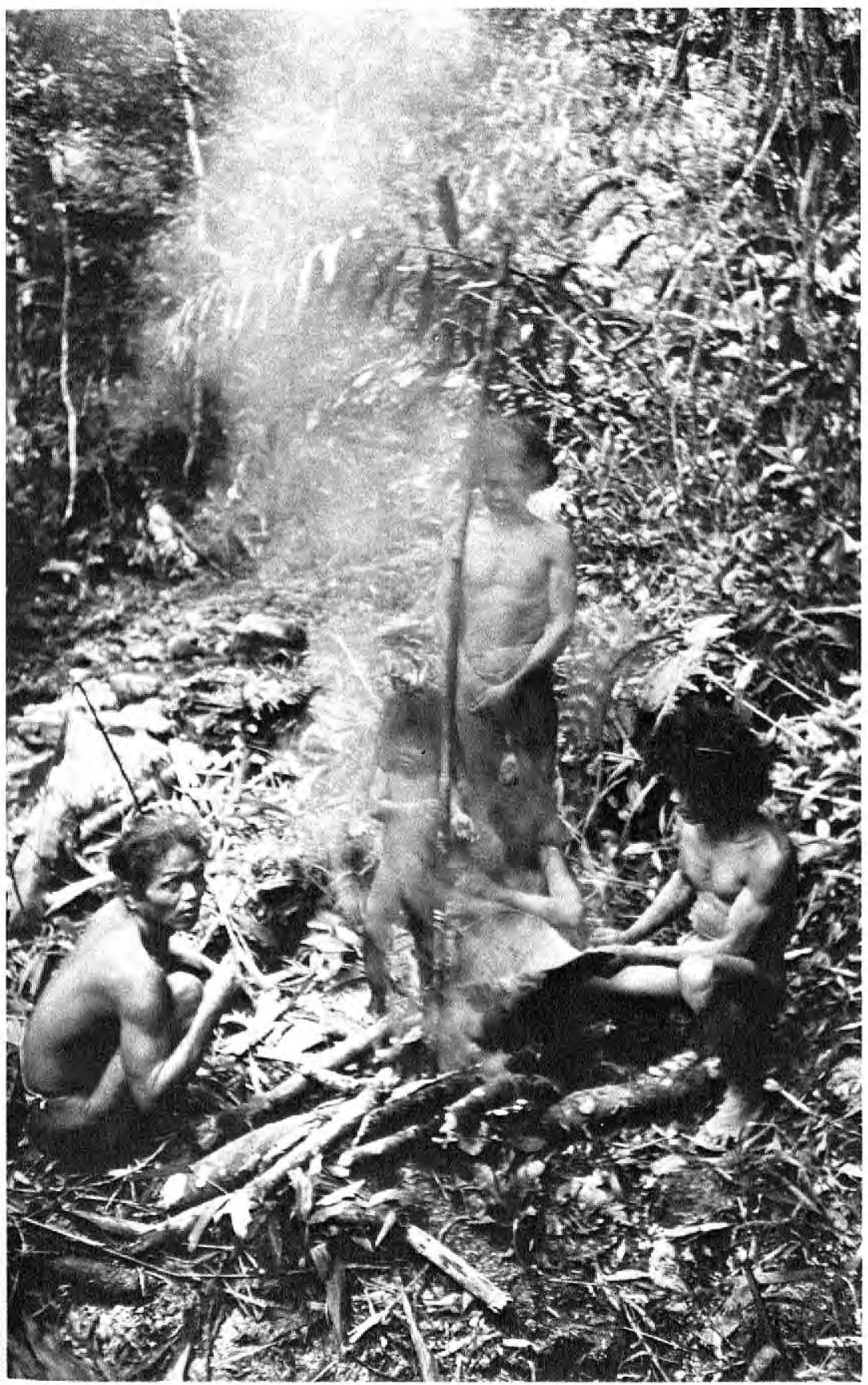

Figure 16e. Cooking sago starch. 


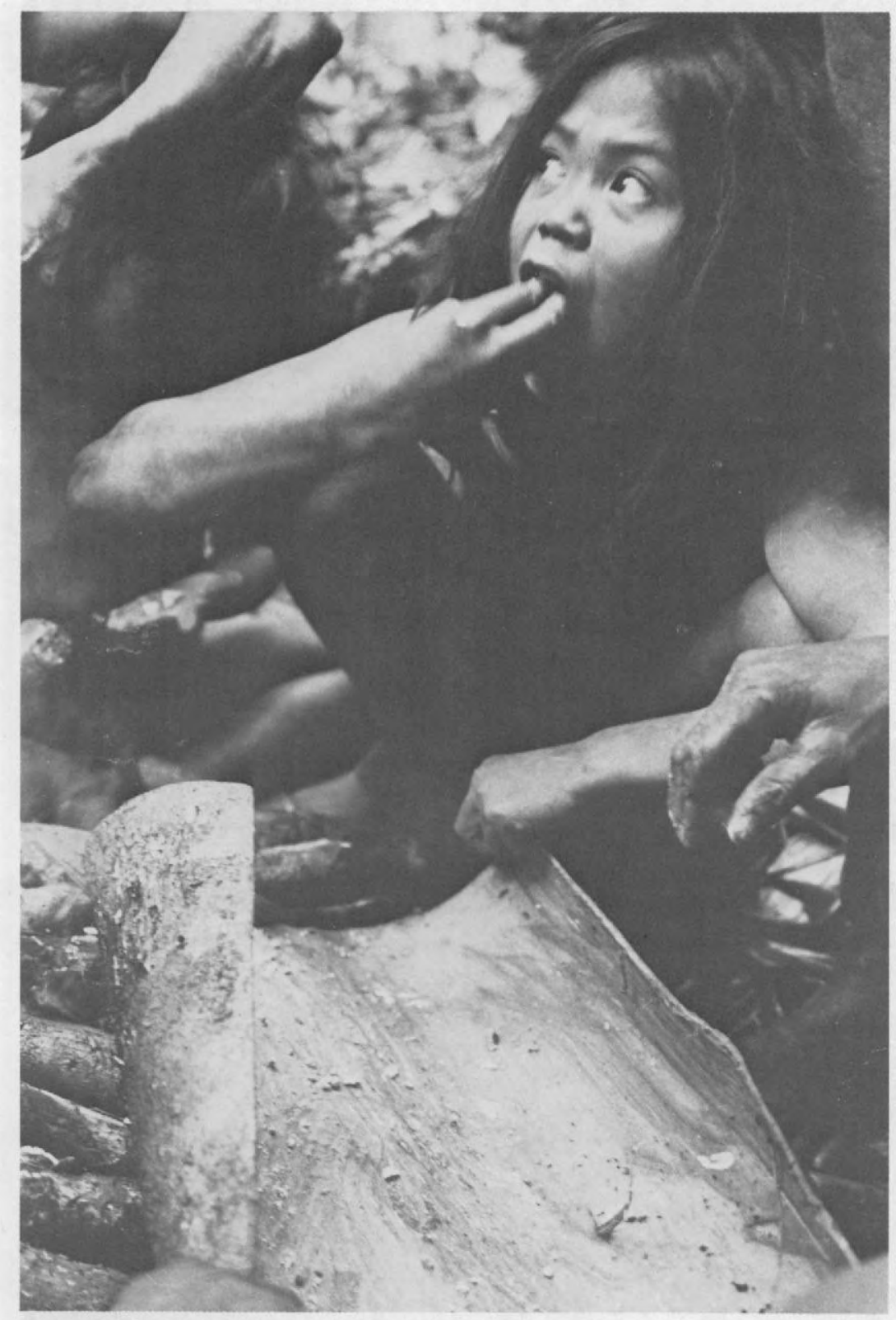

Figure 16f. Eating sago. 


\section{The Contribution of Sago to Subsistence}

Two major factors emerge from an evaluation of sago as a staple, complementary, or emergency food. First, it is almost pure starch and individuals consuming it as a substantial proportion of their diet may thus be in a nutritionally vulnerable position; and second, sago affords a highly productive means of subsistence, considering yields with respect to either land area or labor time.

Most nutritional analyses of sago refer to Metroxylon. Peters (1957) determined the following composition for $100 \mathrm{~g}$ of raw Metroxylon sago:

$\begin{array}{lcll}\text { calories } & 285.0 & \text { calcium } & 30.0 \mathrm{mg} \\ \text { water } & 27.0 \mathrm{~g} & \text { carbohydrate } & 71.0 \mathrm{~g} \\ \text { protein } & 0.2 \mathrm{~g} & \text { iron } & 0.7 \mathrm{mg} \\ \text { fat } & \text { negligible } & \text { fiber } & 0.3 \mathrm{~g} \\ & & & \end{array}$

Although great variations in composition between varieties of Metroxylon are not anticipated, nonetheless, because of wide variations in moisture, these values cannot readily be applied to dietary studies in which the food is weighed as produced or consumed. The water content of raw sago may vary from 20 to 45 percent (Oomen 1971:14). In dietary studies the percentage of water has been estimated, and may account for gross differences in caloric intake reported in studies from different areas.

Sago from other palms, although still mainly a carbohydrate, has a somewhat different composition. For example, Wilbert (1976:319) reports the following composition for sago from Manicaria saccifera, the temiche palm:

$\begin{array}{lr}\text { water } & 63.51 \% \\ \text { protein } & 1.62 \% \\ \text { dextrose } & 5.07 \% \\ \text { starch } & 4.57 \% \\ \text { fiber } & 24.68 \%\end{array}$

The protein-calorie ratio of such tubers as taro, sweet potato, and cassava is lower than that of rice (Oomen 1971:8); sago, however, is even poorer in this respect. Sago also lacks fat, and as a consequence the quality and quantity of foods complementing sago in the diet are of critical dietary importance. Where sago is an abundantly available staple, energy requirements are adequate- 
ly provided for, but dietary balance and nutritional adequacy depend largely on ecological circumstances.

Most areas where sago is the staple are coastal, lacustrine, or riverine, where fish and shellfish regularly are available as a source of animal protein. Game and domesticated animals may also make a significant, if less regular and dependable, contribution to the diet. Away from such areas the protein supply is more precarious. Where population density is low and settlements scattered, as exemplified by the Guayaki of eastern Paraguay (Clastres 1972) and some New Guinea peoples, enough game may be available. This type of adaptation, however, has proven extremely vulnerable to demographic and social change, as in the case of the sago-using Yimar of the upper Korowori River. Since World War II, as a consequence of acculturation, they have settled in larger, composite villages and have abandoned hunting without providing an adequate protein replacement (Haberland and Seyfarth 1974:243 ff.; McArthur pers. comm.).

Many sago areas are drained by blackwater rivers. The upper Korowori River, discussed above, is a blackwater river, as is the Wogamus, the Sepik tributary along which the Sanio-Hiowe reside. Blackwater rivers are low in nutrients and high in humic acids which give the water a dark brown color. These acids are polyphenolic compounds which are toxic to both fish and insect larvae (Janzen 1974:71). Hence, sago-using populations in such habitats seem to be less well provided with fish and other animal protein sources than are communities along clear, white, or muddy rivers. In tropical South America blackwater rivers are traditionally called "hunger rivers."

In interior areas where neither game nor fish are plentiful, vegetable protein sources become more critical. This is the case at Lumi, in Papua New Guinea, where the leaves and fruits of the tulip tree (Gnetum gnemon) are the most important source of protein (Corden 1970:77); it is also a significant complement to sago in several other New Guinea locations. Many other leafy greens, fruits, and nuts, both wild and domesticated, contribute vegetable protein in sago areas.

Populations which allocate sago palms, or portions of them, to the production of grubs have another source of protein and fat. The nutritive value of $100 \mathrm{~g}$ of the uncooked, edible portion of sago grubs of the family Cerambyidae from Papua New Guinea 
was analyzed at the Australian Institute of Anatomy in Canberra (Hipsley and Clements 1947:279):

$\begin{array}{lr}\text { water } & 70.5 \mathrm{~g} \\ \text { calories } & 181.0 \\ \text { protein } & 6.1 \mathrm{~g} \\ \text { fat } & 13.1 \mathrm{~g} \\ \text { carbohydrates } & 9.0 \mathrm{~g}\end{array}$

Nutritional surveys of sago-eating populations are few and somewhat conflicting in their findings. In order to be of maximum value in assessing the nutritional status of a community, such surveys should involve interdisciplinary teams trained to assess not only food consumption, but clinical and biochemical evidence of health and nutritional status, together with related ecological, social and cultural factors. Few nutritional surveys in the regions here under consideration have attained this standard. One of the most thorough was that of the New Guinea Nutrition Survey Expedition (1947), which studied five villages, each with a different staple food. Although obtaining quantitative dietary data in 4 of the 5 villages, the expedition failed to do so in the only sago-using village studied, Korovagi, located in the Purari Delta. Although quantitative data are lacking, the list of available foods indicates a relative abundance of fish and shellfish, with pork and grubs less frequently available, and Gnetum gnemon leaves and fruit as another major, though seasonal, complement (Langley 1947:131, 132). Of the five villages studied, Korovagi residents had the worst general appearance, being abnormally thin and having more scabies, impetigo, and sores than inhabitants of other villages (Hipsley 1947:150). There was, however, no indication of specific deficiencies of vitamins or minerals.

In Lumi, in the Torricelli Range of northwestern Papua New Guinea, sago contributes 72 percent of the caloric value of diet, which for the adult males sampled was only about 1380 calories per day. Very little animal protein is available but fair amounts of dietary protein are contributed by leaves and fruits of the tulip tree and some by immature coconuts (Corden 1970:77).

Waropen, on the north coast of Irian Jaya, is another sago region in which nutrition is inadequate (Oomen and Malcolm 1958). There caloric intake was low because silting of the river had cut off access to formerly productive sago swamps. The diet was mo- 
notonous, with 93 percent of the calories from sago, the major protein source being fish and shrimp.

A somewhat higher food intake is reported from the SanioHiowe in Papua New Guinea. Caloric totals are higher than in either Waropen or Lumi, although protein intake is still very low (Townsend et al., 1973). Although sago contributes 85 percent of calories, the remaining 15 percent is sufficiently diverse to provide a wide variety of nutrients. It includes the meat of wild and domesticated pigs, other game, fish, grubs, and a small amount of many different wild and cultivated vegetable foods. No trained clinical observations of the nutritional status of this population are available.

Although pigs are often a source of protein for sago-eaters, their complementary food role is not well documented. A notable pig-sago resource management system is practiced by the Daribi, Foraba, and Tundawe people, living in interior Papua New Guinea, in the zone where the Chimbu, Southern Highlands and Gulf districts meet. The system is found only in limestone areas, where collapsed dolines and blocked sink-holes provide both natural enclosures for maintaining semidomesticated pigs separate from cultivated areas, and swampy soils suitable for sago. In a few localities, swamps have been created artificially, by damming creeks. Pigs are fed sago not needed for human consumption. Their feeding requires little labor, the palm simply being felled and partly split to permit the pigs to forage (Hughes 1970:272-278).

The most nutritionally adequate sago diet so far reported in New Guinea is that of the Marind of the south coast of Irian Jaya (Luyken and Luyken-Koning 1955). Both game and fish contribute protein, but availability varies from the coast to the interior and between wet and dry seasons. Not every family has meat or fish every day. Clinical examination revealed symptoms of both thiamine deficiency and Vitamin A deficiency. Caloric intake is much higher than reported elsewhere, but the difficulty of exactly assessing quantities of sago consumed was noted.

Nutritional data from other sago regions are largely impressionistic. Fortgens (1909:95), for example, notes, with regard to workers in Maluku, that those who ate sago complemented with meat or fish and greens, were at least as healthy as rice eaters. And van Oijin reported (1909:52) on the endurance and strength of sago-eating Ambonese soldiers.

Another question related to nutrition is the digestibility of sago 
starch. The Sanio-Hiowe of Papua New Guinea claim that certain individuals cannot tolerate sago pudding without vomiting, and must therefore eat sago cooked in other ways. They also regard sago as unsuitable for infants. Since cooking by the stone-boiling method is doubtless not very thorough, these observations are worth noting. Parallel claims of indigestibility seem not to be found where pottery or metal cooking pots are used, thus cooking the starch more thoroughly. The Toradja of Sulawesi forbid consumption of sago by persons with abdominal pain or swelling, believing that sago may contribute to abdominal swelling. The Toradja also prohibit sago use in conditions associated with blood, which is analogous to the reddish color of sago. These Toradja food beliefs, like those of many other societies, are based on the assumption that like produces like, the assumption underlying homeopathic magic.

\section{Sago Yields}

Considerable variability exists in yields among the various palm taxa used for the production of sago (table 3 ). Some are attributable to biophysical differences in the palms or to differences in soil conditions and management techniques. But efficiency with which starch is extracted may vary among societies as a result of differential skill and technology. Many discrepancies also undoubtedly have arisen from inconsistencies of observation, measurement and reporting. Interspecies comparison of yields is facilitated where a community uses more than one type of sago, as, for example, in Halmahera, Indonesia (Fortgens 1909:104). Fortgens cites informants who stated that the starch content of one Metrox$y$ lon trunk equals that of six Arenga trunks, and the sago yield of one Arenga trunk equals that of 15 trunks of $A$ reca, the last used only as an emergency food.

Estimates of the productivity of Metroxylon palms per hectare vary enormously. Warberg (cited in Sprecher von Bernegg 1929: 302) estimated that about 330 sago palms could be harvested per hectare per year. Barrau (1958:39), utilizing data collected in Irian Jaya, claimed that a one-hectare "normal swamp forest stand" produced about 52 harvestable palms annually. Townsend (1969: 77), by contrast, estimated that in the upper Sepik community where she worked, yields per hectare were considerably less, with only about 7 harvestable palms per hectare produced each year. The same yield was found elsewhere in the Sepik area by Edwards 
TABLE 3. Estimates of Sago Yield by Genus

\begin{tabular}{|c|c|c|c|c|}
\hline Genus and Species & Yield $(\mathrm{kg})$ & Location & Reference & Remarks \\
\hline Arenga pinnata & $57-61$ & Indonesia & Miller 1964:125 & \\
\hline Arenga pinnata & 68 & India & Blatter 1926:357 & \\
\hline Arenga pinnata & $50-75$ & Philippines & Hines 1914:228 & $\begin{array}{l}\text { may be either male or } \\
\text { sterile palms only }\end{array}$ \\
\hline Arenga pinnata & 70 & Java & Watt 1908:92 & \\
\hline Arenga pinnata & 70 & India & Roxburgh 1874:670 & $\begin{array}{l}\text { experiment in Calcutta } \\
\text { Botanical Garden }\end{array}$ \\
\hline Arenga pinnata & 25 & Java & $\begin{array}{l}\text { Kerchove de } \\
\text { Denterghem 1878:270 }\end{array}$ & \\
\hline Caryota urens & $102-159$ & Eastern India & Paulose pers. comm. ${ }^{\mathrm{a}}$ & \\
\hline Manicaria saccifera & 3 & Venezuela (Orinoco Delta) & Wilbert 1976:319 & $\begin{array}{l}\text { uncultivated, } 2 \\
\text { specimens }\end{array}$ \\
\hline Mauritia flexuosa & 60 & Venezuela (Orinoco Delta) & Heinen 1972:124 & \\
\hline Metroxylon spp. & $241-302$ & Sabah & Wheatley $1894: 415-416$ & \\
\hline Metroxylon spp. & $272-363$ & throughout range & Blatter 1926:257 & $15 \mathrm{yr}$-old palm \\
\hline
\end{tabular}




\begin{tabular}{|c|c|c|c|c|}
\hline Metroxylon spp. & $180-240$ & Sabah (Beaufort Dist.) & Ruddle 1975 field data & $\begin{array}{l}35 \times 0.7 \mathrm{~m} \text { trunk, Bisaya } \\
\text { village }\end{array}$ \\
\hline Metroxylon spp. & $113-158$ & Irian Jaya & Barrau 1958:39 & $\begin{array}{l}\text { great variations: up to } \\
408 \mathrm{~kg} \text { from sterile } \\
\text { palm }\end{array}$ \\
\hline Metroxylon spp. & $113-295$ & West Malaysia & $\begin{array}{l}\text { Fairweather and Yap } \\
1937: 330\end{array}$ & \\
\hline Metroxylon spp. & 167 & not specified & Flach 1972:854 & cultivated experiment \\
\hline Metroxylon spp. & 159 & S.E. Asia and Melanesia & Flach 1972:854 & uncultivated \\
\hline Metroxylon spp. & 272 & Seram & Wallace $1885: 385$ & \\
\hline Metroxylon spp. & 225 & Philippines (Mindanao) & Wester 1924:174 & \\
\hline Metroxylon spp. & $79-159$ & Papua New Guinea (Fly R.) & Riley $1925: 61$ & \\
\hline Metroxylon spp. & $28-206$ & Papua New Guinea (Sepik V.) & Townsend 1974:227 & \\
\hline \multirow[t]{2}{*}{ Metroxylon spp. } & $29-104$ & Papua New Guinea(Oriomo & & \\
\hline & & Plateau) & Ohtsuka 1975:table I & $\begin{array}{l}\text { uncultivated } \\
\text { and cultivated }\end{array}$ \\
\hline
\end{tabular}

Notes:

In most cases there is very little evidence of field measurement having been made. Some yield data have been converted to kg and all figures have been rounded.

T. T. Paulose, Directorate of Arecanut and Spices Development, Calicut, India. 
(1961:15). Morris (1953:158) estimated that the average yield per hectare per year in Melanau country, Sarawak, was about 10, and did not exceed 15 palms. ${ }^{3}$ Jumelle (cited by Watt 1908:92) stated that in Java 400 Arenga pinnata palms can be planted on about $0.4 \mathrm{ha}$, from which the total stand yield, based on an average of 70 $\mathrm{kg}$ per palm, would be $28,000 \mathrm{~kg}$ of sago. More importantly, Arenga palms, as Watt pointed out, thrive on poor soils where cereals cannot be successfully cultivated.

All such estimates must be regarded with a good deal of caution, as the length of time to maturity and the harvest of palms at various stages of maturity in any tract make estimation of productivity per hectare very difficult. Unlike most subsistence activities, sago productivity per unit of labor is easier to measure than productivity per unit of land. It is not surprising, therefore, that many investigators have reported such observations. Several made within the Sepik area of Papua New Guinea show reasonable consistency. Townsend recorded yields of $2.2 \mathrm{~kg}$ per hour of labor among the Sanio-Hiowe, excluding travel time to and from the site (1974:227). The Abelam have an almost identical output per hour (Lea 1964:122), despite the fact that their yield per cubic foot of pith processed is almost double that of the Sanio-Hiowe. It is not known whether this difference results from higher-yielding varieties of sago or from more thorough extraction, or both. Kwoma output per hour is approximately the same as that of the Abelam and the Sanio-Hiowe output (Whiting and Reed 1938: 179). Slightly higher productivity, $3.1 \mathrm{~kg}$ per hour, is reported from yet another group in the Sepik area (Dornstreich 1973:211).

Data on labor input and sago yield from other areas are more sketchy. Philippine men produced Arenga starch at a slightly lower rate than that reported for Metroxylon in the Sepik: 10 to 15 $\mathrm{kg}$ per man-day (Hines 1914:228). By contrast, the sago workers observed in eastern Seram by Wallace $(1885: 385)$ had a much higher output, of about $40 \mathrm{~kg}$ per day. Tauern (1918:104) also reports high productivity from Seram. Variation of such magnitude is not surprising in the light of differences in work organization, division of labor, extractive technology, and the starch content of different palms.

Sago production offers a highly efficient means of provisioning a community. Following the lead of Carneiro (1957:169) one can compare the efficiency of disparate subsistence economies by the general measure of the man-hours needed to produce one million 
calories. Sago producers rank high on such a scale (figure 17), with outputs similar to shifting cultivation, and higher than sedentary agriculture or hunting and gathering.

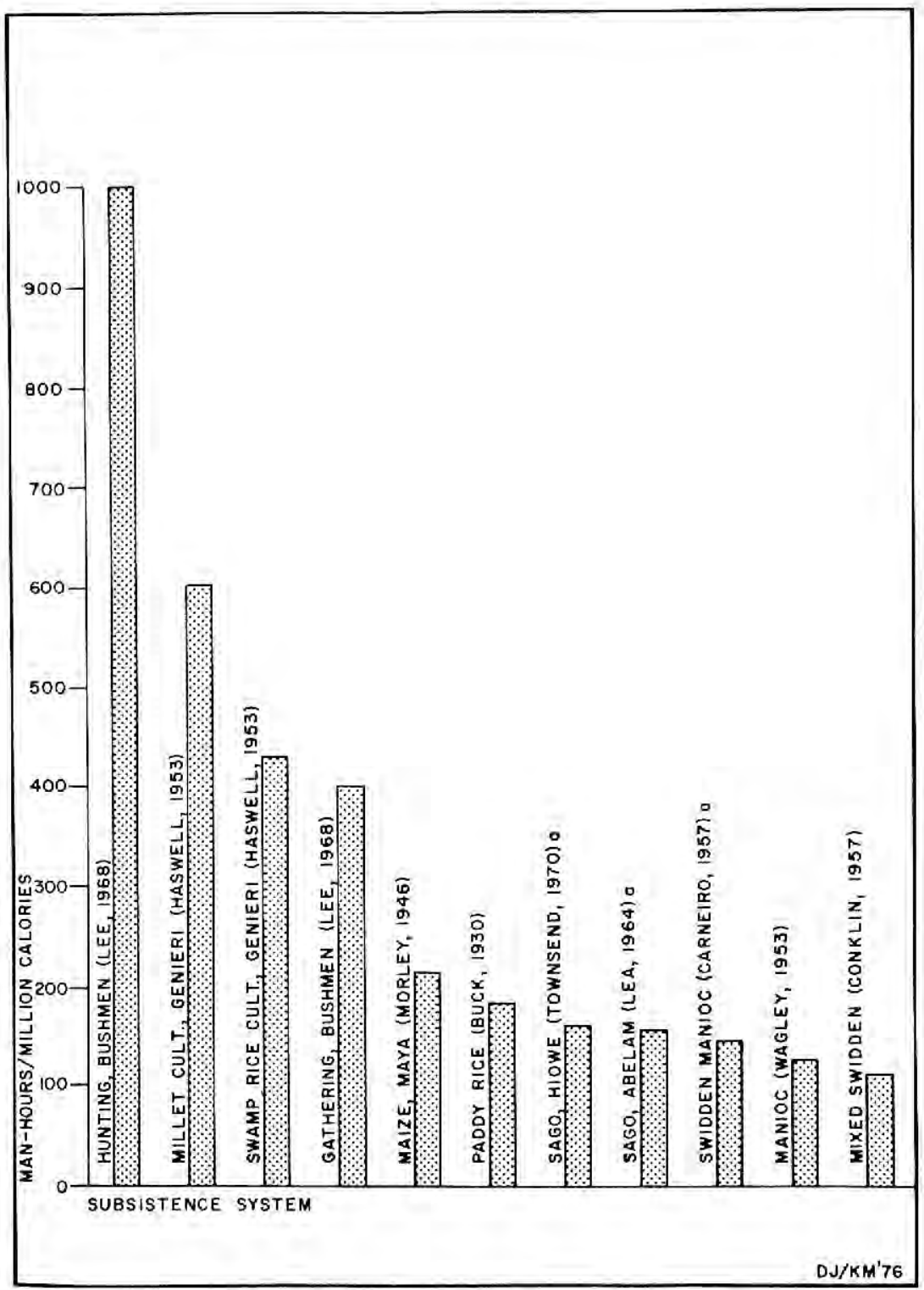

Figure 17. Man-hours required to produce 1 million calories in selected subsistence systems. After Townsend 1970:43. a = Walking to work site excluded. 


\section{Complementary Food Use}

Reports of sago as a complementary food source are numerous, generally brief, and refer to palms of many different genera. Thus, Corypha was described as being utilized by the Bila-an people of southern Mindanao (Cole 1913:85); Caryota in the Mishmi Mountains of India (Griffith 1850:70); Raphia spp. in the Malagasy Republic (Pickering 1879:630); Syagrus coronata in Brazil (Seemann 1856:157; Smith 1876:307); Mauritia spp, in the Amazon (Seemann 1856:252-253); Arenga spp. in India (Pickering 1879:335); and Caryota urens, (kó khuong), together with two other unidentified taxa, $k \delta$ pang and $k \delta$ pung, ${ }^{4}$ by the Montagnards of North Vietnam (Robequain 1929:187). Gourou (1931: 210) also noted the use of sago from various palms by tribesmen in the North Vietnamese mountains. Sago was also produced in the Maldive Islands, presumably as a complementary foodstuff (Planche 1837:215, 217).

In China, Metroxylon sago has long been considered a nutritious and strengthening food. It is included in The Great Herbal (Pen Ts'ao Kang Mu) of the Ming Dynasty, published in 1590, and the method of obtaining sago is given (Smith 1911:389-390). The manufacture of sago from Caryota palms has also had a long history in southern China. Caryota is one of the plants mentioned by $\mathrm{Ki} \mathrm{Han}$, a minister of state under Hui ti of the Tsin dynasty (A.D. 290-307) in his Account of the Flora of the Southern Regions (Nan Fang Ts'ao Mu Chuang). Somewhat later, Kia Sz'niu, who lived sometime in the fifth century, mentioned the use of a sago-yielding palm (Caryota) in his agricultural treatise, Important Rules for the People to Gain Their Living in Peace (Ts'i Min Yao Shu) (Bretschneider 1881:39, 79). In the southern part of Hainan, the Hakka people produce sago from Arenga pinnata (Gross, Ding, and Groff 1923:58). Small amounts of sago are still exported from the People's Republic of China.

Among the Hong Kong Chinese pearl sago (yee mei) is regarded as a mild medicine, as an ingredient of various soups, and as the principal ingredient of a custardlike dessert. As a medicine it is taken mostly by children. It is boiled in water for three hours and used as an aid to digestion and as a cure for sore throat. To make a sweet soup pearl sago is boiled for three hours, and then potatoes and carrots are added.

The Chinese in Sarawak regard pearl sago as a cooling food to 
be used medicinally to alleviate heat stroke. This remedy was also used by British colonists. According to a Bisaya informant, some Chinese in Sabah process the roots of Metroxylon as a simple. The Melanau people of Sarawak add pearl sago to either tea or boiling water, drinking the mixture to cure diarrhea.

In other areas sago reportedly has special food uses. Reynders (1962:59) noted the preparation of sago in the Muju district of Irian Jaya as food for infants not yet able to digest tubers, as did Firth (1950:133) in Tikopia. A thin gruel made from sago is fed to the sick by some peoples in the Purari District of Papua New Guinea (Nolan 1942:11). Owing to the scarcity of Metroxylon along the Maclay coast of Papua New Guinea, sago was regarded as a luxury food by some tribes, who reserved it for feasts (MiklouhoMaclay 1885:349).

\section{Emergency Food}

Palm stem starch is important in some areas as an emergency food during time of famine and scarcity. Copernicia spp. have been described by Koster (1817:366) and Seemann (1856:173) as a famine food in northeastern Brazil. Vellard (1939:84) recalls that in 1870 Paraguayan campesinos used starch from Arecastrum romanzoffianum, a staple of the Guarani Indians, to avoid starvation after the war of the Triple Alliance. In the Philippines and India Caryota spp. are thus exploited in times of scarcity (Burkill 1935:233; Smith 1876:231), as is the Arenga by the Hanunóo tribe of Mindoro (Conklin 1957:87), and the inhabitants of Cavite Province in the Philippines (Hines 1914:227-228). Geddes (1954: 58) notes that in December, Land Dyak "men whose households are running short of rice as a result of poor padi crops last year may now have to pound up Arenga palms for sago." Among the Dyak of the Karimata Islands of Indonesia, Arenga is also of emergency importance (Dewall 1862 cited by Bartlett 1963:208), as is Phoenix farinifera along the east coast of India (Drury 1858: 348; Seemann 1856:314; and Watt 1883:6, 137). Before the rice harvest, the Toradja of central Sulawesi forestall hunger by making sago from Metroxylon, Arenga saccarifera, and the take (unidentified) palms (Adriani and Kruyt 1951:199, 204). Areca sp. is used by the natives of Halmahera, Indonesia, as an emergency source of sago (Fortgens 1909:104). In southern Maluku, Indonesia, the residents of the Tanimbar Islands place a very low value 
on sago and eat it to spare their supplies of staple tubers, particularly yams, and their very limited supplies of highly valued rice (Drabbe 1940:55).

Although probably once a common staple throughout Melanesia, Metroxylon sago is now regarded as famine food in all parts of the region except Papua New Guinea (Brookfield with Hart 1971:85; Codrington 1891:319-320; Firth 1930:107; Ivens 1927: 36; Guiart 1958:35-36). In some parts of Papua New Guinea, however, such as the west coast of Huon Gulf, the Bougainville District, and sections of the east coast of New Ireland, it is regarded as a standby for use only during prolonged emergencies (Chinnery 1929:29; Hogbin 1951:42; Reynolds 1972a:109). In the Lau District of Malaita and in Tikopia, whole sections of the unprocessed pith of palms of this genus were roasted and eaten during times of food shortage (Firth 1950:131).

In the northwestern Solomon Islands, Blackwood (1935:287288) observed that although Metroxylon grew in considerable numbers the pith was not normally eaten, except in times of scarcity, when the taro crop failed. In a recent study of subsistence in the Solomons, Yen $(1974: 256)$ found that sago is considered an emergency food on Santa Cruz, but that on nearby Tömotu Neo it is prized and still eaten as a change from the regular diet of root crops and breadfruit.

Perhaps the earliest record of sago as an emergency food in the Philippines comes from Dampier (1729, vol. 1:310-311). An account dated 1686 mentions emergency sago use by certain tribes on Mindanao for three to four months each year when other starch supplies were exhausted.

The Subanu mountain people of Mindanao distinguish five taxa of sago-producing palms which are exploited only when the rice crop fails. Those most often used are the buri (Corypha umbraculifera), and the lumbia (Metroxylon sp.). Also utilized are the bagsang (Metroxylon sp.) the canong, or cauong (Caryota sp.), and the pagahan (probably Caryota spp.) (Finley and Churchill 1913:19). ${ }^{5}$ A compendium of Philippine resources compiled by Jesuits noted that sago from the buri palm, " . . . tan celebre en todo el Archipielago," constituted an important emergency food on the islands of Masbate, Burias, and Bohol, at the end of the nineteenth century (Misión de la Companiia de Jesús 1900:600).

In the Cotobato and Agusan region of Mindanao, as in the 
moist sections of the Visayas, where extensive sago swamps exist, stem starch from Metroxylon sagu was, by 1924, already relegated to an emergency role (Wester 1924:174). Hart (1954:529) noted that villagers in the central Visayas used Corypha spp., saksak (Metroxylon sagu), ${ }^{6}$ and ediok (Arenga pinnata) ${ }^{7}$ palm sago in emergencies, and that rural inhabitants of the northern Visayas used it frequently before the maize harvest. 


\section{4}

\section{SAGO IN MYTH AND RITUAL}

In some traditional societies the use of palm sago has been of enduring significance not only because it comprises a major component of the diet, but also by virtue of its central position in myth and ritual. Sago is brought into symbolic relationship with the twin concepts of germination of plants and generation of humans. Because of this it often has a central position in food and fertility rituals. In still other societies, in which sago is of equal importance in subsistence, sago has virtually no ritual significance. This contrast has challenged historical and functional explanation.

\section{Origin Myths}

Southeast Asian myths of the origin of sago contain several themes which recur in different combinations throughout the sago-using areas. Stated in their most general form these are: (1) the origin of sago from a culture heroine by birth, vaginal secretion, or defecation; (2) the origin of sago from the corpse of a culture heroine; and (3) the origin of sago palms from a substance scattered by a culture hero.

All of the three themes cited above appear in the Toradja myth of the origin of sago:

A woman repeatedly provided sago porridge for her husband, and the latter could not find out where his wife got this dish. He therefore spied on her and noticed that she made the porridge from the white 
flow from her vagina (others say: from the dirt she scraped from her body). When this became known, people took such an aversion to the woman that they killed her. The Metroxylon grew out of her corpse. This happened on drifting ground that was blown back and forth by the wind. When they chopped into the trunk, blood (red liquid) spurted out of it, and from these blood spatters sago trees grew anew. Those who had chopped into the mother trunk had to pay for this with death, but the trees that had grown from the blood spatters could be cut down without harm. And no more blood came from them. (Adriani and Kruyt 1951:201).

The blood in this myth is related to the reddish color of the pith of certain sago varieties and finds ritual expression in the tabooing of sago to those who are passing blood. In addition to this myth, the Toradja also have a more general myth of the origin of food plants from a corpse. The first human couple is said to have had seven children; six of these formed three married pairs. The seventh, who is male in some versions of the myth and female in others, was killed and buried; from the brains grew the sago palm, from the head the coconut, and from the hair the sugar palm.

The theme of the origin of sago from the corpse of a slain culture hero or heroine would seem to be related to a widespread mythic theme of the origin of root crops from a corpse. Jensen (1963:107-112) traces this theme in both the Old and New World and contrasts it with the myth which explains the origin of cereal crops. He refers to the theme by the term "Hainuwele mythologem" in reference to Hainuwele, the culture heroine of the Wemale of Seram, from whose body various root crops sprang (Jensen 1939:59-65). In his work on myths in Seram, Jensen reports several etiological myths dealing with sago. In one area of West Seram, a myth treats the origin of various palms from the corpse of a grandmother, who dies after her grandson discovers that she has been preparing his food from her body filth and refuses to eat it again. Arenga grows from her head, the coconut palm from her genitals, and the sago palm from her body (Jensen 1939:69). In myths recorded in other locales in West Seram, a mother changes into one or more sago palms and is discovered by her children (Jensen 1939:70). Jensen also records a myth from West Seram in which a bush-hen and a cockatoo argue how they should teach people to work sago. When they fight, the bush-hen hits the cockatoo on the beak with a burning stick. He runs away 
shrieking, leaving the bush-hen to teach people to wash sago by the same motions she uses when she stirs up the ground to build her nest.

The Waropen of Irian Jaya relate a myth in which incest between a brother and sister is implicit. The brother commits suicide in his shame and from his bones arise the sago palm and banana (Held 1957:300).

Myths containing the theme of the slain culture heroine occur in sago-using cultures of Papua New Guinea with significant variations. Among the Sanio-Hiowe of the Sepik area, the myth presupposes the existence of sago and deals with the origin of humanity from the body of the slain cassowary-mother:

A man found a cassowary egg and put it away in a bucket made of the crown shaft of a palm. After several days the egg hatched and out came, not a baby cassowary, but a human baby. When the boy grew up, he cut some yapay sago palms and a few months later gathered the sago grubs from them. While he was preparing a fire to cook the grubs, he decided he wanted some betel nut to eat. He took a multipronged arrow of the kind used to shoot small birds and fish and tried to shoot down a few from the bunch of betel nut growing high on the palm, but the whole bunch fell down. Fearing his father's anger, he put the bunch of betel nut in the house. Then he went to sleep in the house. When his father came home, he demanded angrily, "Who stole my betel nut?" The culprit woke up and told him he had just intended to take a few, but the whole bunch had fallen so he had put it aside in the house for his father to eat. Furious about the betel nut, his father said sarcastically that the offspring of a cassowary, which only knows how to eat wild food, after all, should not expect to eat betel nut. So the son gathered together his belongings and left home.

Not knowing where to go, he walked on and on, followed by his cassowary mother. Finally they came to a hill, where he cleared a spot and made a little shelter. The next day he started cutting timbers for a big house. He spent several days building the house, sewing sheets of thatch and fastening them to the roof, and putting up bark walls. When his house was finished, he planted a garden with bananas, tobacco, and betel nut. Then he cut a sago palm and pounded and washed it himself. He worked sago day after day until he had plenty of it stored in the bush as well as at home. Then he worked in his garden for a while. In time, his sago supply was low again. He left his work in the garden and came to his mother, who was sleeping under the house, to tell her that he was going to work more sago. The cassowary felt 
very sorry about her son having to work his own sago, so she set out to find him a wife. After she walked a long way, she came upon two young women working sago, laughing as they worked. She watched them for a long time to make sure that they were good workers. Near them, hanging on a stump, she saw a net bag containing their shell ornaments. The cassowary grabbed the net bag and took off at a run. The woman saw her take it, grabbed her sago pounder, and chased after the cassowary. Several times the woman got almost near enough to the cassowary to strike her with her sago pounder, but then the cassowary would surge ahead again. Finally, they arrived at the son's house. He had shot a pig in the morning and was making preparations to cook it. When the woman found herself in his garden she realized how far she had come and was afraid the man would kill her. The man saw her arrive in pursuit of his mother, who was carrying the net bag. He invited the woman in to eat, and she explained that she had followed the cassowary who had stolen her net bag. "That's not just a cassowary," he said, "that's my mother." His mother said, "I was sorry for you, having to work your own sago, so I brought you a wife."

Now the man cut sago palms and his wife did the pounding and washing. He told his mother to stay with his wife while he went hunting one morning. But while the woman worked sago, the cassowary went off looking for wild fruit to eat. Thinking she was a wild cassowary, her son shot her. His wife was making sago pudding when he came to ask her if she had seen his mother. She answered, "No, I've been working sago alone." He said, "Tomorrow morning we will go look for her; I'm afraid I have killed her."

After they found the body, he cut a sago log and broke up the inside. Then he cut all the cassowary meat off the bones with a bamboo knife and put it inside the sago log. He cut logs and vine and covered up the sago log and fenced it in so that pigs could not get at it. Then he went away, taking the head and bones of the cassowary, which he put in a pool of water.' His wife continued to work sago in the next few days, but he was upset about his mother's death and just stayed at home. Finally his wife had finished the palm she was working so he went to the swamp to cut another. While he was there he heard little whispering sounds in the sago log where he had put his mother's flesh, like the sounds made by baby cassowaries. He went and told his wife to work the sago he had cut, and then he went back to listen some more. This time he heard voices of men and women talking in various languages.

The man went and told his wife to make skirts. He set to work making armbands and waist hoops for the men. He gathered leaves and nettles, and they cooked sago and sago pudding and gathered ginger 
root, all to give to the people in the sago log. The husband and wife set off carrying all these things to the sago log. When they got there, he stood at the base and she at the top and they removed the vines that were keeping the people tied inside. As soon as they opened it, all the people came tumbling out naked. The wife took all the women to one side and rubbed their skin with nettles to toughen it, and the husband did the same with the men. Then they dressed them up-the women in skirts, the men in a variety of loin coverings, some with flying fox skins, some with cordyline. One man gave him an argument about whether the coconut shell phallocrypt he was given should be worn so that the penis was flipped up or so that it hung down. They gave everyone tobacco to smoke. They gave them sago pudding, but some people couldn't eat that without throwing up so they gave them plain sago to eat. Then they took them home and pierced the noses and earlobes of all the men and women. (Townsend 1969:99-101)

Elsewhere in Papua New Guinea, elements of the Sanio-Hiowe myth occur in other contexts. Among the Mountain Arapesh, the theme of the cassowary-mother slain by her sons is repeated with striking similarity, but here, where yams are the staple and sago only a supplementary food for feasting, yams grow from her body (Mead 1970:290-291; Fortune 1942:185-187, 231-232). And the Mejbrat of Irian Jaya derive the cloth and other valuables which are important in their exchange system from the flesh of the slain cassowary-mother (Elmberg 1968:258, 268).

The Sanio-Hiowe motif of the origin of humanity from a sago palm is repeated in the Fly River region of New Guinea in a myth of the origin of the tribes from a sakr palm, an unidentified palm which is symbolically identified with the sago palm (Williams 1936:304).

Before 'Gainjan' felled the sakr palm out of which the Keraki and the neighbouring peoples eventually issued, he heard within its trunk an unaccountable murmuring of voices. It was to satisfy his curiosity that he took his axe and felled the mysterious palm, so that by bending his ear to the trunk as it lay on the ground he might be better able to distinguish the sounds. Near the upper extremity he found them mere babel, and when he split or lopped the trunk at this point there swarmed out men who spoke the unintelligible language of the Gambadi. Listening again, somewhat lower down, he heard another strange language, and with a few more strokes of the axe he liberated the Semariji. Proceeding thus he next heard Namma, namma, namma-and set free the Tendavi tribe, who when they ask, "What is it?" say Namma- 
$y e m$ ? Thence progressing by stages towards the butt, he successively heard and released the Moive tribe, who say Nemati? the Wekamara tribe, who say Neni?, and so on; until, reaching the very butt at last, he heard his own familiar Numbo? and so set free the Keraki Proper. As they flocked out they threatened Gainjan with their bows and arrows, as each tribe had done before, but their hostility melted when he hailed them as his children and entreated them to speak and gratify his ear with syllables he could easily understand. After this, and before his own ascension into the sky, Gainjan dispatched the peoples and tribes to their present homes, and they very naturally carried their languages and their nicknames with them. (Williams 1936:54-55)

Another theme in the sago myths is the origin of sago from a culture heroine by birth or defecation. In the western interior of Sarmi, northern Irian Jaya, among the Samarokena, the origin of the sago palm is attributed to the marriage of two mythic personages. The woman, Solite, gives birth to a human son and a sago shoot, which when planted, gives rise to all the sago palms (Leeden 1956:185). In the corresponding myth of the Humboldt Bay area of northern Irian Jaya, a woman gives birth to sago starch which gives rise to the first sago palm; and from the placenta, the animals originate (Galis n.d.:258-259). In an explicit way, this myth validates the sexual division of labor, for here it is said if a woman were to cut or pound sago it would be like killing her own child. Women are responsible for only the washing, or sedimentation, process.

The Abelam of Papua New Guinea relate the following origin myth in which a culture heroine who takes the form of a cassowary is responsible for sago as well as for the institution of society and culture (summarized from Schuster 1965:379-381):

While several young women are bathing in a river, a man steals the clothing of one of them, puts it in a bamboo, and takes the woman and the bamboo home with him. One day while the man is gone to his garden, the woman gives his younger brother some coconut meat to eat, and he shows her where his brother had hidden her stolen clothing. She puts the clothing on and turns into a cassowary. When the elder brother returns, she runs off into the bush.

The next day the brothers go to the mountains, taking with them bananas, a hand drum, and a bamboo trumpet. They call the cassowary. Other cassowaries come and reject the bananas, but when the cassowary/woman comes, she eats the bananas. The brothers ride astride the cassowary to a limbun palm, where they all sleep. 
By the next morning, the cassowary has transformed her dung into gardens with food plants and sago. The limbun palm has turned into a tamberan cult house, and the men wake up in this building and go to the door. Outside they see two young women, and their mother, the cassowary, who has again turned into a woman. She tells them that these are the wives she has provided for them, shows them how to use betel nut, prepare sago, plant yams, and build a house. She sends a bee which stings the younger brother on the mouth, changing his language. $\mathrm{He}$ and his wife go away and the cassowary mother also departs. The elder brother and his wife settle here.

A Marind myth from the south coast of Irian Jaya occurs in two versions which invite comparison with the myths discussed above. In one version, the culture heroine, Sangon, defecates, producing sago, and in another version, she gives birth to sago (Baal 1966:336). This Marind myth fits into a series of myths involving Wokabu, Sangon's husband, who is the originator of body paint as well as the first pig hunt, which leads to the first pig feast. At this feast, his wife Sangon eats too much pork fat and defecates, producing sago. She eats it secretly. Her husband searches her house, finds the sago, and after eating some puts the leftovers in his head dress. His sons tell their mother, and she hits her husband, scattering the crumbs of sago. From these morsels a bare sago trunk grows. Wokabu completes the sago palm with leaves formed from sting-rays and sawfish. In succeeding episodes of the myth, Wokabu is involved in the felling, working, and dispersal of the sago palm. The Marind-anim in this myth attribute the origin of sago to the clan which has sago as its totem, but then attribute a specific named variety of sago to each of the phratries in Marind society. The mythological basis for this occurs in an episode in which culture heroes of each group have intercourse with girls lying along both sides of the felled palm. At each of these places, a sago palm of a different variety sprouts (Baal 1966:338).

The motif of a substance which is scattered giving rise to stands of sago palms is widespread. In myths related above, the Toradja refer to spattered blood and the Marind-anim to scattered morsels of sago. The Keraki of the Fly River of Papua New Guinea relate a myth in which the culture heroes Iwa and Pala travel across country dropping bits of toi, apparently a gum or resin. Where the to $i$ was dropped, sago palms grew (Williams 1936:102). This myth 
was directly tied to a ritual held at times of food shortage to promote an increase of food. The ritual was enacted at a place where the culture hero left certain relics, including pieces of toi (Williams 1936:103).

On Normanby Island in southeastern Papua New Guinea the story of the origin of sago was recorded by Schlesier (1965:4-5). The eagle Magisubu lived on the island of Sanaroa, north of Normanby Island. He was a strong bird who killed and devoured people until in his whole district only five people were left. The five remaining attacked him with a spear, but he escaped, badly wounded. Where his drops of blood fell as he flew, sago palms grew up. People did not know how to work sago but the culture hero, E'ela (who was a rat or an animal similar to a rat) discovered that if he simply hit the palm with an axe, starch would flow out into a bowl. Many people came and stole sago by striking the palm until it flowed. E'ela's cousin, the culture hero Magemagege, a small lizard, was angry at the theft and afraid the sago would soon be exhausted, so he stopped up the flow with stones making the pith hard as stone. Magemagege then introduced sagowashing techniques.

Schuster (1965:369-379) reports myths from two societies in the Sepik region of Papua New Guinea which, though otherwise somewhat different from each other, share the theme of the origin of sago palms from a culture hero scattering a substance out of a bamboo container. A myth recorded in Mohem village on the lower middle Sepik River explains how people, who at first ate only earth, were given sago. A man arriving in a tiny bamboo canoe introduces sago as a food to two sisters and then to their parents. At night the man scatters a substance from which arises sago, houses, and, in another version of the myth, other food crops as well. At first sago starch simply flows from a hole in the palm, but the father strikes at the coil of sago starch, thinking it to be a snake, and the flow ceases. From then on people must work to produce sago.

Another sago origin myth was recorded by Schuster in the village of Asangumot on the upper Yuat River, a tributary of the lower Sepik (Schuster 1965:372-373). In this myth, the first man who comes out of the earth finds a series of food crops in the forest, discovers each is good to eat, and plants it; in sequence these crops are banana, sugarcane, sweet potato, yams, and taro. But the man and his wife declare that these are not strong food. 
He then takes a substance from a bamboo container, scatters it, and sago grows up. In this myth, too, sago at first flows like water, but in angry response to a theft of sago, the flow is cut off and the present sexual division of labor in sago work is established.

Similar themes occur among New World sago peoples. Origin from the corpse of a female culture heroine, for example, is clearly expressed in the Warao origin myth of the temiche (Manicaria) palm:

Long ago there was an old woman who followed her husband to live in the lowlands of the Delta. Life was easier for the old couple there than where they had come from, and they greatly enjoyed the cool water of the bogland and the sea breeze that incessantly fanned their new home. The name of the old woman was Yahuhi.

As time went by the woman felt a strange transformation taking place all over her body. First her eyes began to clear up so that she could see well again. Then the wrinkles in her face disappeared, her body firmed up like that of a girl, and her complexion became healthy and youthful looking. Even the voice of the old woman changed back to that of a maiden, and she began to sing with happiness over her regained youth. The husband of the woman was equally taken by surprise and wondered what the cause of this miraculous transformation might have been.

"I have changed because my body was exposed to the cool north wind," said the woman. "Let's remain here forever."

One day the man told his youthful wife that he had to leave the house for a short while. He wanted to go to the field and do some gardening.

"Fine," said the woman. "I shall cook dinner and wait for you. But don't be later than you said."

Time passed, and the man failed to return within the set period of time. While his wife was waiting, she suddenly saw a handsome young man approaching the house from the north. He greeted her kindly and wanted to know where her husband had gone. "He has gone to the field and is overdue." So then the visitor took advantage of the man's absence and seduced the youthful woman.

When the husband finally got home, the suitor had long since left the house, but the husband noticed that something was wrong. Questioning his wife, she finally confessed that a young man had visited and embraced her during his absence. It was his fault, she said. He had left her alone for so long. This made the old man very angry. He prepared a rope and whipped the poor woman so mercilessly that marks began covering her body from head to foot. 
Days went by, and the woman became very ill. Because of the pain she could neither sleep nor eat and, finally, she died.

Since there were no people living in the neighborhood who might have helped the old man bury his wife, the husband tied the corpse to a pole in an upright position. It looked as if the woman was just standing there, alive. And even after a full moon had passed, the woman's body still looked youthful and uncorrupted. After that, however, the dead woman began to change into a tree. The husband left her, and upon looking back a final time, saw that his wife had become a temiche palm. He said to himself: "Once the Warao will come to be on this earth, they will have to call this palm yahuhi, because that was her name as a woman." (Wilbert 1976:286-288)

Wilbert (1976:288-289) explains the etiological content of this simple narrative as " . . . a prolific palm-bearing fruit practically continuously is identified with a fertile young woman. Her fertility is miraculously caused by the wind of the north whence also her youthful lover puts in an appearance. . . . For a Warao listener the introduction of the north wind heralds doom. Furthermore, they blow from the direction where Haburi, the culture hero, lives in a world mountain-tree. As a youth he had unwittingly seduced his own mother." As a result of adultery and incest the woman was transformed into a palm as Haburi was into a world tree. "This sacrifice of metamorphosis results in enormous benefits for mankind," Wilbert continues, "from the transformed woman the ever producing temiche palm. . . ." The myth also explains why the Manicaria favors coastal swamps, with tidewaters and a sea breeze, and the remarkable fertility of the palm.

\section{Other Widespread Themes in Sago Mythology}

The theme of sago starch flowing from the palm without human effort in mythic times is widespread in the sago-using areas. Examples from the Sepik and Yuat and from Normanby Island in Papua New Guinea have been cited. From a nearby people, the Yimar of the upper Korowori, Haberland and Seyfarth (1974:234-235) report a narrative of the discovery of sago by a dog that scratched a hole in the trunk. The dog ate the sago which flowed out. The dog returned home, his mistress ate some of the dog's excrement, and she discovered what good food this was. The woman began getting sago from the palm in the same way and fed it to her husband but concealed its origin from him. When her husband followed her to satisfy his curiosity, the flow of 
starch ceased and from then on it was necessary to work sago. Another myth of the effortless flow of sago starch is reported from the Toradja in Sulawesi (Adriani and Kruyt 1951:202). And in central Borneo the Kajans tell the story that it was once possible to simply cut a hole with an axe and rice would flow from the palm. A man plugged the hole with a piece of his bark loincloth. $\mathrm{He}$ returned to find the bark grown through the whole interior, which had become sago instead of rice. Now it was necessary to pound the pith with wooden hammers and trample it out with water (Nieuwenhius, cited in Oijen 1909:37). In the New World, Warao myths also refer to a golden age in which sago was obtained without effort (Wilbert 1972:294).

Another widespread motif in sago mythology is that of the transformation:

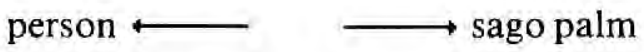

This transformation is central in Warao narratives dealing with the moriche palm (Mauritia flexuosa), the major source of sago in the Orinoco Delta of Venezuela. In the etiological tale "How the moriche palm came to be," Indians discover strange people in a distant place who do not answer when spoken to. The Indians notice that the man has blossoms and the woman has fruit. They cut the people down, and as they fall they become real moriche palms. Another motif of transformation is found in the Warao tales of the lonely young man who carves himself a mistress from moriche wood. Her name is Mokototo, spider hole, in explanation of the characteristic holes marking the palm trunk (Wilbert 1972:221, 224, 363-364).

The shaping of a human effigy from sago pith is a motif repeated in a New Guinea myth previously referred to, the myth from Asangumot village on the Yuat River. In a continuation of the myth of Bambooman, the first people are said to be lacking in kinsmen, and in order to add to their number, they shape figures from sago pith, which are transformed into real people after they eat a cannibal meal (Schuster 1965:376). The actual shaping of effigies from sago in ritual contexts is not as widely reported as the corresponding motif in myth: one instance is the Melanau of Sarawak, whose ritual for curing illness requires the carving of an image of the disease-causing spirit from sago pith. The image is bespelled, the spirit enters the image, and it is carried to the jungle or river (Morris 1953:144). 
Many other symbols are associated with sago in myth; however, only one more will be discussed here. This is the symbolic association between sago and the moon which is widely reported in New Guinea (Landtman, 1927:102; Williams 1936:301-304; Haberland 1966b:86). The myth of the origin of the moon from a chunk of sago starch thrown into the sky is perhaps only too obviously suggested by the color and nature of the substance, but the association of both the moon and sago with female sexuality should also be noted.

\section{Myth as a Clue to History}

When we consider the amount of ethnobotanical investigation that has been devoted to the prehistory and history of such food crops as the sweet potato, the paucity of knowledge concerning the history of the various sago palms and their use is striking. The botanical difficulties of studying palms are, of course, forbidding. One of the main avenues of historical investigation into sago palens thus far has been the content and distribution of myths, the rich narrative tradition surrounding sago which has been sketched above.

The most direct way in which myth may be used as a clue to ethnobotanical history is to take the content of the myth literally as quasi-historical. Schuster (1965:374-375) presented this possibility in his analysis of several sago origin myths from the Sepik region, then quickly qualified this attempt by indicating that the sequence of food plants presented in each myth may be a better reflection of their present economic importance than of their history. In the myth from the lower middle Sepik, people first ate earth, then sago, followed by bananas and tuber crops; in the Chambri myth, sago followed taro and fish, then came yams, and in the text from the upper Yuat all the other food crops preceded sago. Literal interpretations of traditions about the introduction of sago may best be treated simply as suggestive hypotheses for checking against other data. For example, the Melanau of Sarawak claim that the Metroxylon they cultivate was brought from the east by the culture hero Tugau. The ancestors of the Melanau are said to have lived up on the hills and to have processed sago from another palm, possibly Eugeissona (Morris 1953:150). This tradition contains highly plausible hypotheses which may be testable against archeological evidence.

Practically the only scholars who have concerned themselves 
with historical problems of sago palm use have been German ethnologists, working in a methodological tradition which stresses meticulous comparative and distributional studies of existing cultures as the means to reconstruct culture history. The data used are drawn from all aspects of culture, especially material culture, but also language, social organization, myth, and ritual. Such distributional studies of culture traits led Speiser $(1946: 25)$ to postulate a very early hunting and gathering culture stratum in New Guinea. The cultural inventory of these seminomadic people, as reconstructed by Speiser, included the use of sago, the cylindrical axe, the dugout, wooden club, bone dagger, fish weir-basket, netting, penis-gourds and shells, poorly developed ceremonial life, and disposal of corpses by cremation, exposure on platforms, or burial lying down. Working in the same methodological tradition Schmitz (1960) reconstructed a series of three cultural strata in the Huon Peninsula. He argues that sago was the staple food in the earliest stratum, although in the Huon Peninsula, Culture A, the oldest of the three strata, now remains intact only in the mountainous interior, beyond the environmental limit of the sago palm.

In order to test Speiser's hypothesis of an earlier prehorticultural sago-using culture in New Guinea, Schlesier amassed the source materials on sago in New Guinea (1961). In support of the hypothesis he concluded that: (1) The sago areas of New Guinea are occupied by speakers of non-Austronesian languages; (2) These groups intensively utilized sago in a wide variety of ways suggesting that they have had sago for a long time; and (3) Sago is thoroughly integrated into the socioreligious system of these cultures. Furthermore, even in cultures where sago is now only a supplementary food, it sometimes has similar socioreligious significance.

In disagreement with Speiser and Schlesier, Haberland (1966b) argued that the use of sago was a much more recent, secondary development arising from impulses out of agricultural areas. He built his argument on linguistic and mythological materials drawn mainly from the lower and middle Sepik area. He demonstrated the probable diffusion of words for sago and of a myth attributing the knowledge of sago-working techniques to the younger of a pair of antagonistic brothers. Both the linguistic evidence and the gradual simplification of the myth from the north coast toward the interior, appear to indicate diffusion from coast to interior. 
Additionally, he indicates surprise that a food plant of such importance in the diet as sago should have as little ritual significance as it does in the Sepik area, unless it were of recent origin. In a later work (Haberland and Seyfarth 1974:233-236), the entire argument is restated with one major modification: the new suggestion that the mythological evidence may simply reflect the diffusion of new techniques for the preparation of sago by sedimentation and that unprocessed sago pith may have contributed to the diet of early hunting and gathering populations in such areas as New Guinea. Haberland did not claim that his conclusions could be generalized even to all of New Guinea, let alone all sago-using areas, but his most general point can be applied to these other areas: that is, that one cannot assume that either an economy which appears primitive or a food plant which is as important as sago is necessarily ancient. The Tasaday adoption of sago processing in the Philippines in the last decade is a fresh reminder of the rapidity with which profound changes in subsistence may be accepted (Fernandez and Lynch 1972).

\section{Sago in Ritual}

A cross-cultural view of the ritual role of sago is characterized by striking contrasts: the humdrum, secular treatment of sago production in most societies in contrast to a few societies in which sago appears in spectacular ritual cycles as a symbol of the fertility of crops and humans.

A survey of the ethnographic literature dealing with sago-using peoples reveals very little that could be called sago-working magic. This absence is noteworthy because it occurs in regions where there is no lack of productive magic in other economic activities such as gardening or hunting. As indicated above, Haberland (1966a:84) was impressed by the lack of ritual significance accorded sago in the Sepik area. Townsend (1969:110) also noted an absence of ritual in the upper Sepik community where she worked. Where sago-working magic is described at all, it is often quite abbreviated. For example, Kaowerawédj women of Irian Jaya paint a white band across their chests so that they may be able to pound sago well and place a piece of turtle shell in their water dipper to assure that a large amount of starch will settle out (Eechoud 1962:115). Oosterwal notes that in the Tor area of Irian Jaya sago-pounding songs have magical efficacy (1961:61). 
Among the Asmat of Irian Jaya, the men are said to cut sago palms almost in silence to avoid scaring away the ghost in the palm, taking the good sago with him (Amelsvoort 1964:36).

The Toradja of Sulawesi make small offerings of sago on the path leading to the sago washing place to divert spirits and evil influences from the work. They also avoid completely emptying the sago trough as they work, for fear that the longer they work the less starch they will gain (Adriani and Kruyt 1951:204). The Alfur of Seram fasten leaves of a shrub and a palm to the washing trough in a magical act intended to prevent the loss of starch in the sedimentation process (Tauern 1918:183). The most elaborate ritual procedures for working sago that have been described in Indonesia are those of Tanimbar, where sago is not even the staple crop but is regarded as inferior food to be used in the lean season. Each step of the sago-working process is marked by rituals, which include offerings, prayers and ritual hunts (Drabbe 1940:80-81).

This generally weak development of sago magic should perhaps not be surprising. Sago production is a relatively low-risk economic activity, both in being safer and of more certain outcome than hunting, fishing, or horticulture. Functionalist and psychological theories of magic suggest that magic will be focused instead on high-risk activities. The performance of the ritual, by serving to reduce stress and increase confidence, may improve the individual's performance in the productive activity. In low-risk activities not demanding a high level of performance, people may be less motivated to undertake ritual precautions, even if the appropriate procedures are already available in the culture.

In still another respect, sago is ritually neutral. Sago as a food is rarely the subject of food taboos, even in societies where food taboos are complex and significant. As in the case of sago-producing magic, the evidence is largely negative evidence, the failure to record such taboos, rather than direct evidence that sago is not tabooed while other foods are. Among the Sanio-Hiowe of Papua New Guinea, a complex system of taboos proscribes different varieties of game animals, fish, birds, and vegetable foods for different sex and age categories of people as well as for people undergoing various life crises such as pregnancy and lactation, illness, initiation, and mourning (Townsend 1969:118-126). The consumption of sago, the staple food, is not tabooed except in mourning. A new widow in seclusion, whose dietary strictures are 
so severe that she may eat almost nothing but wild yams, is not allowed to eat sago until her husband's bones are removed from the burial platform for secondary burial. In addition, other mourners abstain from the variety of sago which they were eating at the time of the death. ${ }^{2}$ The Sanio-Hiowe seem to be typical of sago-using societies in placing minimal restrictions on sago consumption.

The Toradja of Sulawesi are exceptional in the number of circumstances under which the consumption of sago is forbidden. Most of these have a basis in sympathetic magic. Because its reddish color leads to its association with blood, sago is avoided by those who are passing blood, and it is not eaten by lepers. Because it is associated with swelling of the body, it is avoided by those with abdominal swelling or pain. The woman leading the rice harvest avoids eating sago during rice cutting lest the smoothness of sago porridge make the rice soul slip away. The Toradja also forbid the mixing of sago from Metroxylon and Arenga (Adriani and Kruyt 1951:206).

The neutrality of sago as a food is most strikingly demonstrated among the Guayakí of eastern Paraguay. The Guayakí place numerous taboos on the consumption of game and honey (Clastres 1972:152, 157) which are important food resources, but the equally important pith and terminal shoot of the pindó palm (Arecastrum romanzoffianum) are free from all dietary prohibitions. The neutrality of the pindo shoot or starch makes it the essential complement to eating human flesh. Guayakí cannibalism is of a form unusual in South America: the boiled or roasted flesh of dead relatives is eaten. Human flesh is so powerful that if it were eaten alone it would cause illness. But cooking it with pindo pith or shoot neutralizes the power and removes the danger (Clastres 1968:40).

Although elaborate ritual use of sago is more the exception than the rule, there are some societies in which sago plays a central role in ritual, particularly in rites related to fertility. Among these, the outstanding examples are the Warao of the Orinoco Delta in Venezuela and the Kiwai of the Fly Delta in Papua New Guinea.

The moriche (Mauritia flexuosa) palm provides the Warao with their principal source of starch. Starch-gathering activities were of critical importance in the traditional food quest, but the availability of starch shows very strong seasonal and regional variation. 
Before root crops were introduced and became widely cultivated, this seasonality led to a pronounced scarcity during certain months and to outright famine every four or five years. The nahanamu, the principal ritual involving the consumption of moriche starch, fulfilled an important economic function by preventing the immediate consumption of large quantities of starch, and, by requiring that starch be stored in the temple for many months, it ensured the distribution of starch precisely during the period of greatest food scarcity. The priest-shaman directed the ritual with supernatural support for decisions regarding the timing of the ritual. The nahanamu ritual also served to channel surplus food among subgroups, thus constituting an important survival mechanism and contributing to the preservation of tribal identity (Heinen and Ruddle 1974).

During two decades of field research among the Warao, Wilbert (pers. comm.) has assembled unpublished data that clearly indicate that the entire relationship between members of that tribe and the Mauritia palm also constitutes a complex fertility cult, concerned with the fertility of both plants and humans. This is demonstrated in the nahanamu festival when men perform a dance with a large stick inserted beneath their loin cloths to represent an erect penis, and when men and women pantomime sexual assaults on straw effigies of the opposite sex.

While moriche sago is their primary starch source, Wilbert (1976) has recently discovered that the Warao formerly made use of a secondary source of starch, the temiche palm, Manicaria saccifera, as an emergency food. Although the temiche is much lower in yield and could never have been quantitatively significant, the two types of starch form a distinctively contrastive pair of symbols. Both types of starch are said to be acceptable to the supernaturals in offerings, in part because both are odorless. But fresh moriche starch is white, whereas temiche starch is brown, and on this contrast is built a day/night contrast in the ritual use of the palms. Moriche starch is appropriate for the "gods of the zenith and the world mountains at the cardinal and intercardinal points of the universe" (Wilbert 1976:323). Dark temiche starch is associated with the god of the dark underworld and the midnight sun. Just as the Warao use moriche starch in their nahanamu festival, they believe that the people of the underworld, and the monkeys as well, make use of temiche starch in their own nahanamu festivals (Wilbert 1976:323). 
The Kiwai people of the Fly Delta of Papua New Guinea use Metroxylon sago as a staple foodstuff. Their moguru, or "lifegiving ceremony," is carried out to promote human fertility and longevity and to enhance the starch production of their sago palms (Landtman 1927:351-367). The ceremony, held at least annually, comprises a number of interwoven episodes involving the preparation of life-giving medicine for the gardens (especially for the sago palms) and for the tribesmen; the sexual initiation of pubescent boys and girls; the capture of a wild boar; and a series of minor rites.

The Kiwai prepare life-giving medicine in a sacred receptacle (baru) made from the smooth stem covering of the Metroxylon palm. A ceremonial mother and father, who conduct all the rites of their totem group, begin by felling a sago palm with a stone axe which has been anointed with her vaginal secretions. The newlymade baru is also anointed with vaginal secretions and semen from the ceremonial father. Next, sago is made in the baru, observing special rules. The receptacle is taken to the men's house and a number of sweet-smelling medicinal plants are added to the sago while the men are dancing: "The whole occasion is calculated to cause sexual excitement. . . . In groups, one after another, the men betake themselves to the women's compartments, where soon promiscuous intercourse is in progress." Men ejaculate into the baru, and the women contribute their secretions. "Everybody seems to be intent upon contributing as much as possible to the medicine, so that the baru should be filled up, and a great number of men, summoned from other villages, render assistance, their wives being among the other women." Meanwhile, dancing and singing continue. Landtman recorded fragments of songs which exhort the palms to produce much sago.

The next day, the medicine is distributed to each man, who pours it into a coconut bowl and adds red coloring. He then smears the mixture on the trunk of one sago palm which he exhorts " . . . to grow large and yield plenty of food." Generally, some of the medicine is also either buried in or sprinkled over the garden, and occasionally suckers are treated with a mixture before planting. A number of Metroxylon suckers are also taken into the men's house during this ceremony. They are handed from man to man, each of whom passes them around his body. Afterwards they are planted.

The Kiwai have an account in their oral history which parallels 
certain sago origin myths discussed earlier in this chapter and deals with the planting of sago:

A certain magician named Segera ... had sago for his totem. When his son died, the death was set down to the magic of an enemy, and the bereaved father was so angry that by his speech he caused the whole crop of sago in the country to fail; only in his own garden the sago grew as luxuriantly as ever. When many had died of famine, the people went to him and begged him to remove the spells which he had cast on the sago palms, so that they might eat food and live. The magician, touched with remorse and pity, went round planting a sago shoot in every garden, and the shoots flourished, sago was plentiful once more, and the famine came to an end. When Segera was old and ill, he told the people that he would soon die, but that, nevertheless, he would cause their gardens to thrive. Accordingly, he instructed them that when he was dead they should cut him up and place pieces of his flesh in their gardens, but his head was to be buried in his own garden. (Frazer 1911, pt. 4:101).

Also as part of the moguru ceremony a captured wild boar, painted and exquisitely decorated, and borne on a litter, is slaughtered, cooked, and then eaten by the oldest people of the village. The boar also yields medicine for the gardens, and for the sago palms in particular. A ritual burial in the palm grove is made to ensure that palms will yield starch and not just water when felled. Included in the burial are several parts of the animal, including pig skin smeared with human semen and a small piece of dried human flesh representing the culture hero Marunogere. Such garden medicines are considered to be extremely powerful and must therefore be buried at a safe distance from the palm, otherwise, it is thought, the villagers would sicken and die from eating poisoned sago. Similarly, to encourage a good sago yield, pig blood mixed with refuse from the previous sago-making is poured into the leaf axils of a palm. Pig blood, bone and skin, together with the coconut leaves on which the sacrificial pig was deposited, may also be burned and the ashes smeared on the palms with the same objective.

The life-giving medicine is also applied to the people themselves, the women rubbing it over their husbands' bodies. Small amounts are taken from the baru, added to other sago and eaten by older people to extend their lifespan. It is also consumed by pubescent children as an aphrodisiac which is expected to act in the future. 
At the conclusion of the moguru the old couple who acted as ceremonial mother and father are rewarded with valuable gifts, for the Kiwai claim that they owe the prosperity of the sago palms to the old folks. The appreciation is deeper, however, as the couple is expected to die shortly thereafter, a belief probably related to the terminal flowering habit of the Metroxylon palm.

Among the Kiwai, prestige accrues to those group leaders who are able to provide the enormous quantities of sago and other foodstuffs consumed at various great ceremonies. Vast quantities of sago are eaten at the mimia ceremony (connected with the initiation of youngsters), and the gáera, or "ceremony of the fertility tree." In the latter ceremony, harvest festival celebrations and the fertility cult are again intimately interwoven. The gaera is too great an undertaking for one man alone, so the whole community assists by contributing food, and in preparing and tending several new gardens specially made for the great occasion.

Thus both the Warao and the Kiwai, though widely separated geographically, have developed important fertility rites around the symbolic use of the sago palm and the distribution of sago starch in feasting. Other accounts in the ethnographic literature are not as rich as these, but suggest some of the same themes.

The Waropen of Irian Jaya make sacrifices of sago mush, tobacco, or palm wine to appease the ancestors before a raid, or in fishing or some other endeavor. They also use sago cakes modelled in the shape of a mythical snake, the moon, a sago pounder, or other figure, in life crisis rites for children, such as the fitting of the first leg rings and the ceremony of perforating the nasal septum (Held 1957:143, 146, 170, 176). The people of Amboina, Indonesia, followed a ritual involving sago as a special food for infants. A lock of the infant's hair was cut and buried under a sago palm before the child was permitted to eat sago pudding for the first time (Frazer 1911, pt. 2:276).

The Kimam of Dolak Island, Irian Jaya, have elaborate rituals involving yam, taro, cassava, and the coconut palm; sago, however, is not cultivated in association with any such rituals, despite its being an important foodstuff. The sago palm is involved, however, in an episode of the elaborate initiation rites for pubescent boys. A raft is made by placing sago leaves across a number of canoes. On the raft are placed heaps of food, drink, a slaughtered pig, and finally the initiate atop the pig. While the boy's female relatives wail and sing as if in mourning, "the men 
constantly pour sago over the boy's head and back in order that he may grow up to be a great cultivator"' (Serpenti 1965:162). The Mimika, also located on the south coast of Irian Jaya, like the Kimam, use sago in ritual ways which symbolize its role in producing life and growth. Here, too, it is part of the male initiation ceremony, during which the young man stands on a lump of sago (Pouwer 1955:213). Sago is closely associated in Mimika ritual with women, who do most of the work in producing it.

\section{Sago Symbolism and the Sexual Division of Labor}

The people of the Tor river valley, west of Jajapura in Irian Jaya, depend almost exclusively on sago, which thus has great significance in their social and religious life (Oosterwal 1961:57, 1967:165). Among the Tor people the entire property rights to the sago palms are invested in the women, and women undertake all of the production labor, including felling. Of all foods, sago has the highest social and religious value: it is a token of "vitality" and sometimes of life itself. A Tor " . . woman herself is the giver of life and that in a double sense. It is she who bears the children and again she is the one who sustains the community through her production of sago"' (Oosterwal 1961:81).

Sago is inextricably embedded in the continuity of life via its association with marriage and sexual intercourse. "The only marriage ceremony in the Tor district consists of the woman giving sago to her future husband, prepared by herself as a consolidation of the marriage bond" (Oosterwal 1961:81). "The woman dips her fork into the sago-mash first and gives her prospective husband his first mouthful. Then the man goes on eating with his own little fork, without giving the first mouthful with his fork to his wife" (Oosterwal 1961:100). Oosterwal interprets this as symbolic of the man's dependence on the woman as the provider of nourishment, for, despite the fact that the husband provides the woman with fish and pork, without sago a meal is incomplete. "The offering of pepeda (sago mash), however, to just any man means the same as sexual intercourse." Incest rules forbid men to accept sago from specified females, for "... when he accepts the pepeda he does have sexual intercourse with her" (Oosterwal 1961:81-82). The sago fork is a phallic symbol which bachelors show ostentatiously to females with whom they wish to have intercourse. "Expressions also, in which the word "sago" or "pepe- 
$d a$ " occur, as a rule also refer to sexual intercourse. During the marriage ceremonies, for instance, the bystanders crack all sorts of jokes referring to the sexual intercourse of the young couple, which are worded in sago terms" (Oosterwal 1961:82).

Sago as the symbol of the female appears in the initiation of youths and in the prohibition of particular men from entering sago groves. The symbolic importance of the female-sago relationship is stated by Tor men who emphasize the need for marriage in these terms: "How can a man live without being married?" or "How can a man eat when he has no wife?" (Oosterwal 1961:99).

The center of all Tor religious phenomena is the cult house, or faareh, the repository of the sacred flutes. The house is decorated with three kinds of symbols: the bat (flying fox), which is believed responsible for planting the sago palms; the moon, which is thought to possess the "vitality" to make sago, other crops, pigs, and children grow to biological maturity; and the phallus, the symbol for stimulating fertility and the procreation of new life.

In the middle of the cult house a long center post (bor: penis) extends down from the ceiling. The culmination of the feast inaugurating a new cult house is reached when this massive phallic symbol is chopped and then twisted off some two meters above the floor. This symbolic action is connected with a number of fundamental Tor myths, particularly those concerning the origin of humans and the making edible of the all-important sago, via the murder of a giant, demonic, nonhuman, male figure, Borgesoe, by his wife, Mauwria, who twisted off his penis (Oosterwal 1961: 223-226). After the death of Borgesoe, myth records that men were taught to blow the sacred flutes, the sight of which is forbidden to women, so that the natural order might be preserved: "... rain falls in good time, the sago will grow, the crops will come up and ripen, sun and moon will keep on giving their light, children will be born, men are protected from disease and death, etc. If the flutes are not blown or do not bring forth the right sound, chaos and death will reign'" (Oosterwal 1961:234).

The above discussion of the people of the Tor represents an extended example of sago as symbolic of female sexuality, in a society where sago is the staple and sago work almost exclusively women's responsibility. In the culture of the Tor region, giving sago is equated with sexual intercourse, hence its role in the mar- 
riage ceremony and the incest taboo. These are themes common to other sago-using societies. For example, in southern Irian Jaya on the Mappi River, the public giving of the marriage sago by the woman to the man is the decisive act in the marriage proceedings (Boelaars 1958:78-79); and among the Arapesh, parents may not eat sago worked by their children, a taboo which protects the parent from the child's developing sexuality (Mead 1970:415).

Although the supporting data are unevenly available, it seems possible to make the general statement that where sago work is women's work, sago is a symbol of female sexuality in myth and ritual but where sago is men's work, the male phallic symbolism of sago is developed. Examples of feminine symbolism are plentiful in the mythological and ritual data presented above. Fewer examples of masculine symbolism have been discussed. In the Tangu narrative of Nuakai and the Sago Palm (Burridge 1969:217-220, 230-233), two brothers work sago, as men normally do in Tangu society. When the brothers take refuge from an angry old woman by climbing a sago palm she tries to cut it down, first with her thumb and fingers and then with her vulva, before finally succeeding with an axe. The sago palm in the narrative is equated with the male phallus (Burridge 1969:389). To the Mejbrat of Irian Jaya the term $a w f$ refers to sago flour and sometimes sago porridge as well as to semen (Elmberg 1968:287), another instance of masculine symbolism, at least on a linguistic level.

If the symbolism of sago is founded in the division of labor, upon what is the division of labor based? At first glance, the division of labor in sago work seems as arbitrary as it is rigid. In some societies all sago work is assigned to women, in others all sago work is assigned to men, in still others the work is divided, usually on fairly rigid lines: men cutting, pounding, or rasping the pith, and women washing out the starch. Often the division of labor is itself charted in myth, as in the Humboldt Bay origin myth cited above, in which a woman gives birth to sago, from which it is argued that if a woman were to cut or pound sago it would be like killing her child. And in Waropen mythology primeval men and women lived separately. They led a sorry existence, the women living in the forest with only sago to eat and the men with only fish, which they try to supplement by eating charcoal. Real human existence, and a proper diet, only became possible when men and women united (Held 1957:316-317). On Normanby Island, the 
rigid sexual division of labor which assigns sago work to men is extended so far as to taboo sexual intercourse when sago work is underway, for even female mana on the hands of the sago washer can spoil the product (Schlesier 1965:14-15). Even in the rare instance of a culture where either men or women may perform a task, there may be arbitrary cultural constraints. So, for example, Mimika men and women both pound sago. But a woman holds her left hand above the right and raises the pounder above her head on the left side, while a man holds his right hand above and makes a bigger stroke above his right shoulder. Performing the task in the inappropriate manner for one's sex produces great hilarity (Pouwer 1955:37).

The sexual division of labor in sago work appears to be less arbitrary when sago is considered in relation to the total subsistence economy. In general, where sago is the primary carbohydrate staple (complemented by hunting, fishing, gathering, and only small amounts of gardening) men may fell the palm, but both pounding and washing are the exclusive responsibility of women. This is the case in the Tor area (Oosterwal 1961:59), the Kaowerawedj (Eechoud 1962:130), the Samarokena (Leeden 1956:12), the Asmat (Amelsvoort 1964:36), and the Marind (Wirz 1922:88) of Irian Jaya, and the Sanio-Hiowe (Townsend 1974:223) of Papua New Guinea, among others. Where sago is one of several staples or a supplementary food and women are increasingly more occupied by rice- or tuber-gardening activities, men often come to share in sago work, usually pounding while women wash. This is the case for example among the Kwoma ${ }^{3}$ (Whiting and Reed 1939: 179) and the Gadio Enga (Dornstreich 1973:207) of Papua New Guinea, the Warao of Venezuela (Suárez 1968:75), and the Melanau of Sarawak (Morris 1953:31-32). In at least some parts of Indonesia where sago is the primary food source, but women have responsibility for rice or cassava gardens, men do all of the sago work (Adriani and Kruyt 1951; Cooley 1962:11; Tauern 1918:104). Finally, where sago is a relatively minor source of food, or a food reserved for times of scarcity or for feasts rather than a regular item in the diet, it is normally produced by men. This is true of Tikopia (Firth 1950: 133-134), the Siuai (Oliver 1955:311), Busama (Hogbin 1951:72), Wogeo Island (Hogbin 1939:306), and Me'udana (Schlesier 1965:14).

Ecological variables, in particular the distribution of sago 
stands in relation to other resources, may also affect the division of labor. Among the seminomadic Mimika of the south coast of Irian Jaya, men work sago along with the women in upriver camps, alternating with periods of net fishing along the coast in which the entire group cooperates (Pouwer 1955:14). Parties of Nuaulu men in Seram make extended trips to localities where naturally propagated sago grows, staying away from the village for five days or longer and combining sago work with hunting (Ellen 1975:140), another instance of the distribution of resources affecting the division of labor. In a discussion of Etoro subsistence in Papua New Guinea, Kelly (1974:69) analyzes the selection of garden sites in proximity to mature sago stands in terms of the interdigitating requirements for male and female labor at the period of peak demand, when major gardens are being cleared.

Although differences of ecology and history may thus result in modifications of the basic pattern, the allocation of sago tasks to men and women is often predictable in terms of the rest of the subsistence pattern, with women responsible for the major starchy staple, whether this is sago or some other crop, and men generally responsible for variety in the diet and much of the protein component. This socioeconomic foundation underlies the myth and ritual discussed earlier in this chapter. 


\section{5 \\ MODERN COMMERCIAL SAGO \\ PRODUCTION IN SABAH, BRUNEI, AND SARAWAK}

Since earliest times insular Southeast Asia has been the main area of sago production. It is based almost exclusively on the exploitation and cultivation of Metroxylon. In that region local commerce and trade in sago products has a similar long historical record.

Modern manufacture of palm sago has developed from traditional extractive procedures and seems to have followed European intervention. The sago palm remains a commercial crop in Indonesia and Malaysia, where processing has been industrialized. Singapore was formerly an important sago processing center, and Singapore merchants remain important in the trade.

Six commerical starch products are obtained from the sago palm: sago pith, wet sago, sago flour and meal, pearl sago, sago biscuit, and sago refuse. Sago pith is the unprocessed material chopped from the palm trunk. Wet sago, the unrefined starch extracted from rasped pith, is an item of local commerce in producing areas. Normally it is produced by villagers and sold to merchants for processing into sago meal and flour, which is obtained by further washing, filtering and sedimentation, and sun drying. In Sarawak, village merchants refine wet sago into two export grades of flour, and smaller quantities are used for the production of pearl sago and sago biscuit.

Pearl sago is dry, partially gelatinized, translucent pellets of starch, prepared by baking moist globules of kneaded sago flour. 
Originally the term was applied to pearls derived solely from sago starch, but nowadays an almost indistinguishable starch obtained from manioc and other tubers goes by the same term. Government of India standards, for example, now define sago as a product of either the sago palm or manioc tuber (Central Food Technology Research Institute 1955:7). Most palm-derived pearl sago is now produced in Malaysia, formerly also in Singapore. According to Smith (1876:1006) the making of pearl sago was introduced by the Chinese.

Sago biscuit is the name given to small, roasted cakes of sago flour mixed with rice bran. In Malaysia, sago biscuit is prepared for family consumption and is also sold to merchants for local resale and export. Sago refuse is the fibrous material remaining after starch has been sedimented, and is widely used as a pig-feed.

Aside from West Malaysia, Sabah and Brunei, standard data on sago production and on palm hectarage are not regularly collected. Sago production is now of little consequence in West Malaysia. In view of this, and because we did not conduct a field survey there, we confine our comments here to tabular form only (table 4). Current data on the status of the domestic industry are not available for Indonesia, although sago-producing palms grow throughout Indonesia and sago is a local staple in many areas.

\section{Sabah}

Sago flour production, although long established, is of comparatively minor importance in the agricultural economy of Sabah, where it is produced for local consumption (table 5). Production is now concentrated in the Beaufort area, and on the Klias peninsula. In the early twentieth century the main producing areas were Beaufort, Kuala Penyu, Kota Klias, Padsdamit, and Membakat. One processing factory was located in Beaufort, another in Kota Klias, and three in Membakat. Another processing plant was also operated by the "Chartered Company" near Labuan Island. Factory production, which came to a halt during the Japanese occupation, revived with the end of hostilities, and continued until the industry was almost destroyed by labor-wage competition occasioned by a rubber boom during the Korean War.

Ruddle surveyed the current status of the industry during a visit to Sabah in July, 1975. The following material on Sabah is derived from that visit. 
TABle 4. West Malaysia: Area under Sago Palms, 1960

\begin{tabular}{|c|c|c|c|c|}
\hline \multirow[b]{2}{*}{$\begin{array}{l}\text { State } \\
\text { District } \\
\end{array}$} & \multicolumn{2}{|c|}{ Compact Area } & \multicolumn{2}{|c|}{ Scattered Trees } \\
\hline & $\begin{array}{l}\text { No. of Farms } \\
\text { Reporting }\end{array}$ & $\begin{array}{l}\text { Area }^{\text {a }} \\
\text { (ha) }\end{array}$ & $\begin{array}{l}\text { No. of Farms } \\
\text { Reporting }\end{array}$ & $\begin{array}{l}\text { No. of } \\
\text { Trees }\end{array}$ \\
\hline Johore & 852 & 603 & 8,680 & 42,122 \\
\hline Batu Pahat & 410 & 409 & 3,980 & 19,578 \\
\hline Johore Bahru & 2 & 2 & 66 & 784 \\
\hline Kluang/Segamat & 246 & 97 & 436 & 1,920 \\
\hline Kota Tinggi/Mersing & - & - & 236 & 1,058 \\
\hline Muar & 150 & 61 & 2,353 & 11,726 \\
\hline Pontian & 44 & 34 & 1,604 & 7,056 \\
\hline Kedah & 164 & 32.2 & 7,902 & 75,408 \\
\hline Baling & - & - & 784 & 2,328 \\
\hline Bandar Bharu & - & - & 246 & 1,200 \\
\hline Kota Star North & 4 & 0.8 & 986 & 18,434 \\
\hline Kota Star South & 2 & 0.4 & 974 & 6,418 \\
\hline Kuala Muda & - & - & 130 & 438 \\
\hline Kubang Pasu & 130 & 28 & 2,934 & 34,264 \\
\hline Kulim & - & - & 434 & 1,230 \\
\hline Langkawi & - & - & 166 & 2,806 \\
\hline Padang Terap/Sik & 28 & 3 & 964 & 6,160 \\
\hline Yen & - & - & 284 & 2,130 \\
\hline Kelantan & 106 & 33.4 & 9,302 & 119,010 \\
\hline Bachok & - & - & 684 & 4,962 \\
\hline Kota Bharu & 40 & 12 & 1,640 & 37,858 \\
\hline Machang & 2 & 0.4 & 1,018 & 8,002 \\
\hline Pasir Mas & 20 & 16 & 3,036 & 25,938 \\
\hline Pasir Puteh & 22 & 2 & 900 & 16,332 \\
\hline Tanah Merah/ & & & & \\
\hline Ulu Kelantan & 22 & 3 & 1,264 & 11,718 \\
\hline Tumpat & - & - & 760 & 14,200 \\
\hline Malacca & 336 & 115 & 3,348 & 26,648 \\
\hline North & 204 & 85 & 1,502 & 15,744 \\
\hline South/Jasin & 92 & 26 & 1,620 & 10,112 \\
\hline Central & 40 & 4 & 226 & 792 \\
\hline Negri Sembilan & 40 & 4 & 8,978 & 37,696 \\
\hline Jelebu/Seremban & - & - & 1,430 & 6,282 \\
\hline Kuala Pilah & - & - & 4,952 & 17,226 \\
\hline Port Dickson & - & - & 24 & 94 \\
\hline Tampin/Rembau & 40 & 4 & 2,572 & 14,094 \\
\hline Pahang & - & - & 70 & 3,446 \\
\hline Bentong/Raub & - & - & 180 & 346 \\
\hline C. Highlands & - & - & - & - \\
\hline Kuantan & - & - & 22 & 208 \\
\hline
\end{tabular}


TABLE 4. (cont.)

\begin{tabular}{|c|c|c|c|c|}
\hline \multirow[b]{2}{*}{$\begin{array}{l}\text { State } \\
\text { District }\end{array}$} & \multicolumn{2}{|c|}{ Compact Area } & \multicolumn{2}{|c|}{ Scattered Trees } \\
\hline & $\begin{array}{l}\text { No. of Farms } \\
\text { Reporting }\end{array}$ & $\begin{array}{l}\text { Area }^{a} \\
\text { (ha) }\end{array}$ & $\begin{array}{l}\text { No. of Farms } \\
\text { Reporting }\end{array}$ & $\begin{array}{l}\text { No. of } \\
\text { Trees }\end{array}$ \\
\hline \multicolumn{5}{|l|}{ Pahang (cont.) } \\
\hline Lipis/Jerantut & - & - & 72 & 166 \\
\hline Pekan & - & - & 222 & 1,534 \\
\hline Temerloh & - & - & 204 & 1,192 \\
\hline \multicolumn{5}{|l|}{ Penang and Province } \\
\hline Wellesley (P.W.) & - & - & 352 & 1,902 \\
\hline P.W. Central & - & - & 44 & 132 \\
\hline P.W. North & - & - & 182 & 1,324 \\
\hline P.W. South & - & - & 4 & 60 \\
\hline Penang & - & - & 102 & 386 \\
\hline Perak & 152 & 162 & 7,442 & 43,588 \\
\hline Batang Padang & 20 & 4 & 106 & 242 \\
\hline Dindings & - & - & 66 & 338 \\
\hline Kinta & 26 & 18 & 546 & 4,248 \\
\hline Krian & 42 & 40 & 1,910 & 7,756 \\
\hline Kuala Kangsar & - & - & 1,878 & 13,020 \\
\hline Larut \& Matang & - & - & 1,054 & 6,970 \\
\hline Lower Perak & 44 & 84 & 256 & 3,664 \\
\hline Parit & 20 & 16 & 640 & 3,180 \\
\hline Selama & - & - & 308 & 962 \\
\hline Upper Perak & - & - & 678 & 3,208 \\
\hline Perlis & - & - & 2,052 & 37,444 \\
\hline Selangor & 102 & 67.4 & 1,912 & 12,840 \\
\hline Klang & 2 & 0.4 & 160 & 540 \\
\hline Kuala Langat & - & - & 186 & 660 \\
\hline Kuala Lumpur & - & - & 442 & 7,006 \\
\hline Kuala Selangor & 100 & 67 & 106 & 302 \\
\hline Sabak Bernam & - & - & 128 & 196 \\
\hline Ulu Langat & - & - & 520 & 2,810 \\
\hline Ulu Selangor & - & - & 370 & 1,326 \\
\hline Trengganu & 4 & 0.8 & 2,618 & 17,734 \\
\hline Besut & - & - & 576 & 2,632 \\
\hline \multicolumn{5}{|l|}{ Dungun/ } \\
\hline Kemamang Marang & - & - & 126 & 254 \\
\hline Kuala Trengganu & 2 & 0.4 & 1,298 & 12,470 \\
\hline Ulu Trengganu & 2 & 0.4 & 618 & 2,378 \\
\hline \multicolumn{2}{|c|}{ Total West MaLaysia } & $1,017.8$ & & \\
\hline
\end{tabular}

SOURCE:

Federation of Malaya 1960: table 761, p. 79.

Note:

a Converted from acres and rounded. 
TABLE 5. Sabah: Estimated Production of Sago, 1970

\begin{tabular}{|c|c|c|}
\hline $\begin{array}{r}\text { Residency } \\
\text { District } \\
\end{array}$ & $\begin{array}{l}\text { Area } \\
(\text { ha })^{\mathrm{a}}\end{array}$ & $\begin{array}{l}\text { Production } \\
\text { (M.T.) }\end{array}$ \\
\hline \multicolumn{3}{|l|}{ Tawau Residency } \\
\hline Tawau & - & - \\
\hline Lahad Datu & - & - \\
\hline Semporna & - & - \\
\hline Sandakan Residency & - & - \\
\hline Sandakan & - & - \\
\hline Kinabatangan & - & - \\
\hline Labuk/Sugut & 30 & 6,713 \\
\hline Total Sandakan Residency & 30 & 6,713 \\
\hline \multicolumn{3}{|l|}{ West Coast Residency } \\
\hline Kudat & - & - \\
\hline Ranau & 16 & 3,629 \\
\hline Kota Belud & 11 & 2,540 \\
\hline Tuaran & 4 & 907 \\
\hline Kota Kinabalu & 43 & 9,706 \\
\hline Penampang & 187 & 42,002 \\
\hline Papar & 356 & 79,921 \\
\hline Total West Coast Residency & 617 & 138,705 \\
\hline \multicolumn{3}{|l|}{ Interior Residency } \\
\hline Beaufort & 2,044 & 458,212 \\
\hline Kuala Penyu & 485 & 108,770 \\
\hline Sipitang & 0.4 & 90 \\
\hline Tenom & 52 & 11,702 \\
\hline Pensiangan & - & - \\
\hline Keningau & 21 & 4,717 \\
\hline Tambunan & - & - \\
\hline Total Interior Residency & $2,602.4$ & 583,491 \\
\hline Labuan & 31 & 6,985 \\
\hline TOTAL SABAH & $\overline{3,280,4}$ & 735,894 \\
\hline
\end{tabular}

SOURCE:

Wong, I. F, T., 1973a, 1973b, 1973c.

NoTES:

a Converted from acres and rounded.

b Converted from pikuls ( 1 pikul $=60.48 \mathrm{~kg}$ ) and rounded; average yield per ha estimated by source at 224 M.T. 
TABLE 6. Sabah: Size of Farms Growing Sago, 1970

\begin{tabular}{|c|c|c|c|c|c|c|c|c|}
\hline $\begin{array}{r}\text { Residency } \\
\text { District }\end{array}$ & $\begin{array}{l}0-5 \\
\mathrm{ac}\end{array}$ & $\begin{array}{l}5-10 \\
\mathrm{ac}\end{array}$ & $\begin{array}{l}10-25 \\
\text { ac }\end{array}$ & $\begin{array}{l}25-100 \\
\text { ac }\end{array}$ & $\begin{array}{l}100-500 \\
\text { ac }\end{array}$ & $\begin{array}{l}500-1000 \\
\text { ac }\end{array}$ & $\begin{array}{l}1000+ \\
\mathrm{ac}\end{array}$ & $\begin{array}{l}\text { Total } \\
\text { Farms } \\
\end{array}$ \\
\hline \multicolumn{9}{|l|}{ Tawau Residency } \\
\hline Semporna & - & - & - & - & - & - & - & - \\
\hline Tawau & - & - & - & - & - & - & - & - \\
\hline Lahad Datu & - & - & - & - & - & - & - & - \\
\hline Total & - & - & - & - & - & - & - & - \\
\hline \multicolumn{9}{|l|}{ Sandakan Residency } \\
\hline Sandakan & - & - & - & - & - & - & - & - \\
\hline Kinabatangan & - & - & - & - & - & - & - & - \\
\hline Labuk and Sugut & 1 & 2 & 1 & 1 & - & - & - & 5 \\
\hline Total & 1 & 2 & 1 & 1 & - & - & - & 5 \\
\hline \multicolumn{9}{|l|}{ West Coast Residency } \\
\hline Kudat & - & - & - & - & - & - & - & - \\
\hline Ranau & 8 & 4 & - & - & - & - & - & 12 \\
\hline Kota Belud & 5 & 2 & 1 & - & - & - & - & 8 \\
\hline Tuaran & 6 & - & - & - & - & - & - & 6 \\
\hline
\end{tabular}


Kota Kinabalu

Penampang

Papar

$25 \quad 2$

Total

$\begin{array}{ll}- & - \\ 5 & - \\ 6 & -\end{array}$

Iterior Residency

Beaufort

Kuala Penyu

Sipitang

Tenom

Pensiangan

Keningau

Tambunan

Total

Labuan

TOtAl SABAH

$\begin{array}{rrrrrrrr}76 & 54 & 47 & 18 & 5 & 1 & 1 & 202 \\ 70 & 34 & 12 & 8 & 2 & - & - & 126 \\ 1 & - & - & - & - & - & - & 1 \\ 2 & 2 & 3 & 2 & - & - & - & 9 \\ 9 & 3 & 1 & - & - & - & - & 13\end{array}$

SOURCE:

Siew 1973a, 1973b.

NoTE:

Units not converted to metric system owing to inability to specify exactly where in converted grade size classes a particular farm should be placed. 
Sago grows principally on small holdings: 53 percent of the total on holdings of less than 2 ha (table 6 ); 24 percent of those between 2 and 4 ha; and only 23 percent on holdings of more than 4 ha. Most holdings recording sago are found in only three districts, in the southwest of the state: Beaufort, 31 percent; Papar, 21 percent; and Kuala Penya, 20 percent.

The largest concentrated area of sago palms in Sabah occurs in the extensive equatorial freshwater peat swamp areas of the Beaufort District, in the vicinity of the Padas and Klias Rivers. Throughout most of the other suitable areas of the country, however, Metroxylon occurs in small groves, around the edges of wet rice fields, and in the lower, swampy depressions which separate higher land planted with rubber. Sago palms are not generally found in the rice fields themselves or interplanted with the various fruit trees, nipa palms, and bamboo of the dooryard gardens. Such landscapes occur between Tanjonaru and Papar (figures 18 and 19). Away from the main producing district, and particularly in the rice-growing areas, many dead Metroxylon palms and

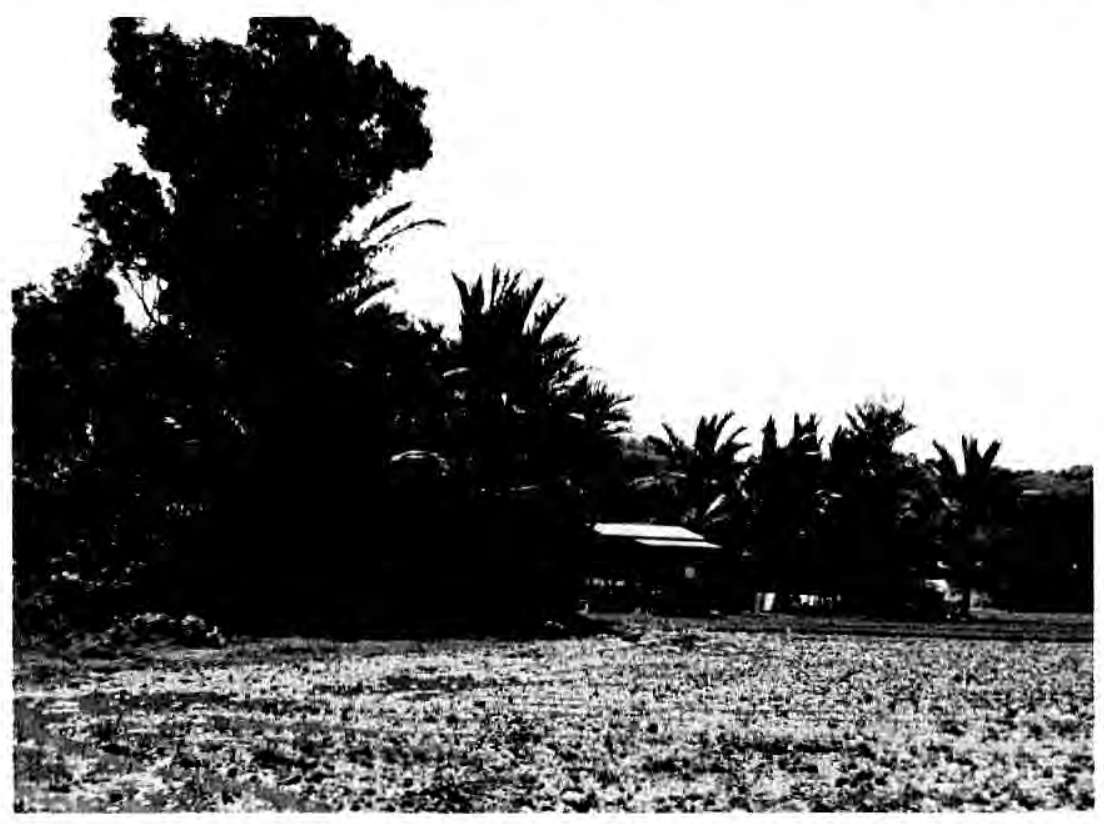

Figure 18. Away from the main sago-producing areas of Sabah, Metroxylon palms are found mostly around the edges of rice fields, and ... . 
others in flower or fruit testify to the underutilization of sago (figure 20).

The bulk of regular sago processing continues to be concentrated in the main producing districts. But throughout Sabah, individual farms, such as those near the village of Tangilan, in Tuaran District, occasionally process a few palms for subsistence and to feed their livestock. Generally, sago flour produced on such farms is not marketed beyond the community.

In July, 1975, Ruddle noted that nine villages (kampong) in the Beaufort District were regularly engaged in sago production for both subsistence and commercial purposes: Gadong, Kapawa (Gadong), Silaun Gramma, Balik, Koridak, Gramma (Ulu), Gramma (Laut), Kabajang, and Lawa. The field survey concentrated on Silaun Gramma.

At Silaun Gramma, a typical village of the Bisaya people, the sago lands are owned by the extended family which works them. Wild stands are exploited and no attempt is made to cultivate sago palms. In the Beaufort District in general, particularly among

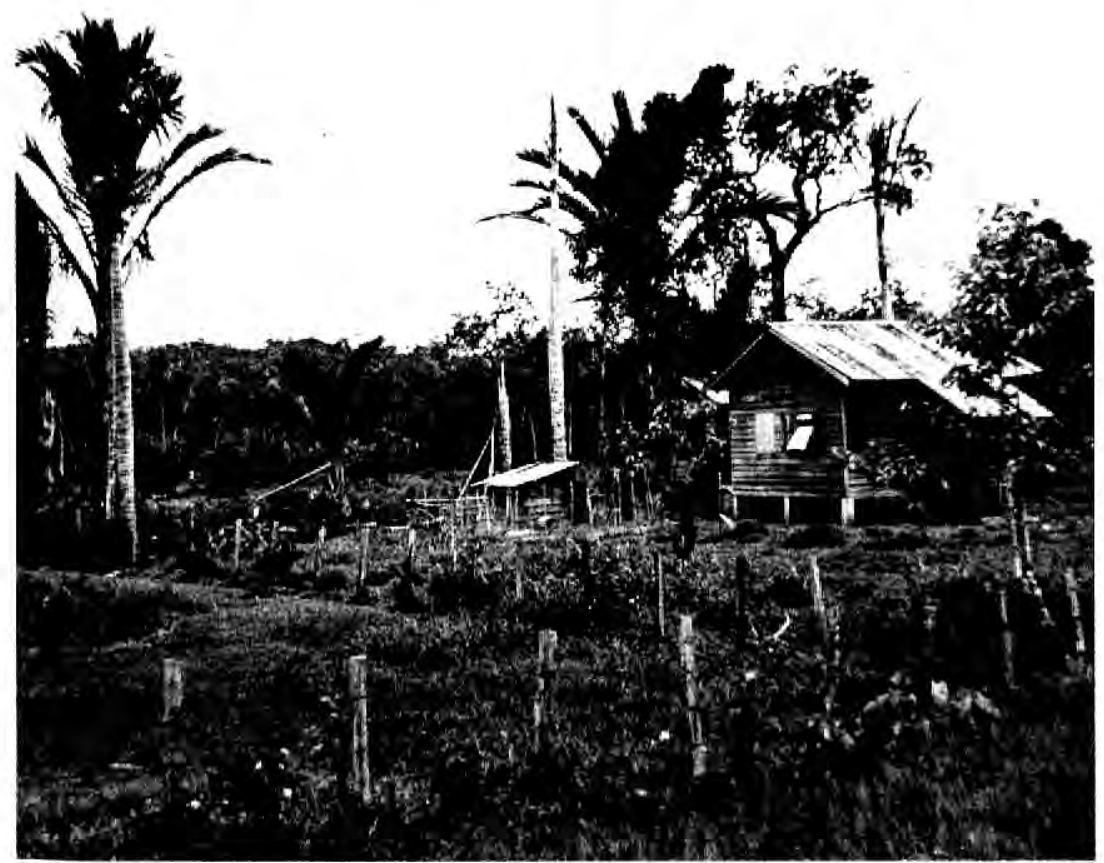

Figure 19. . . . in swampy depressions between plantings of rubber. 


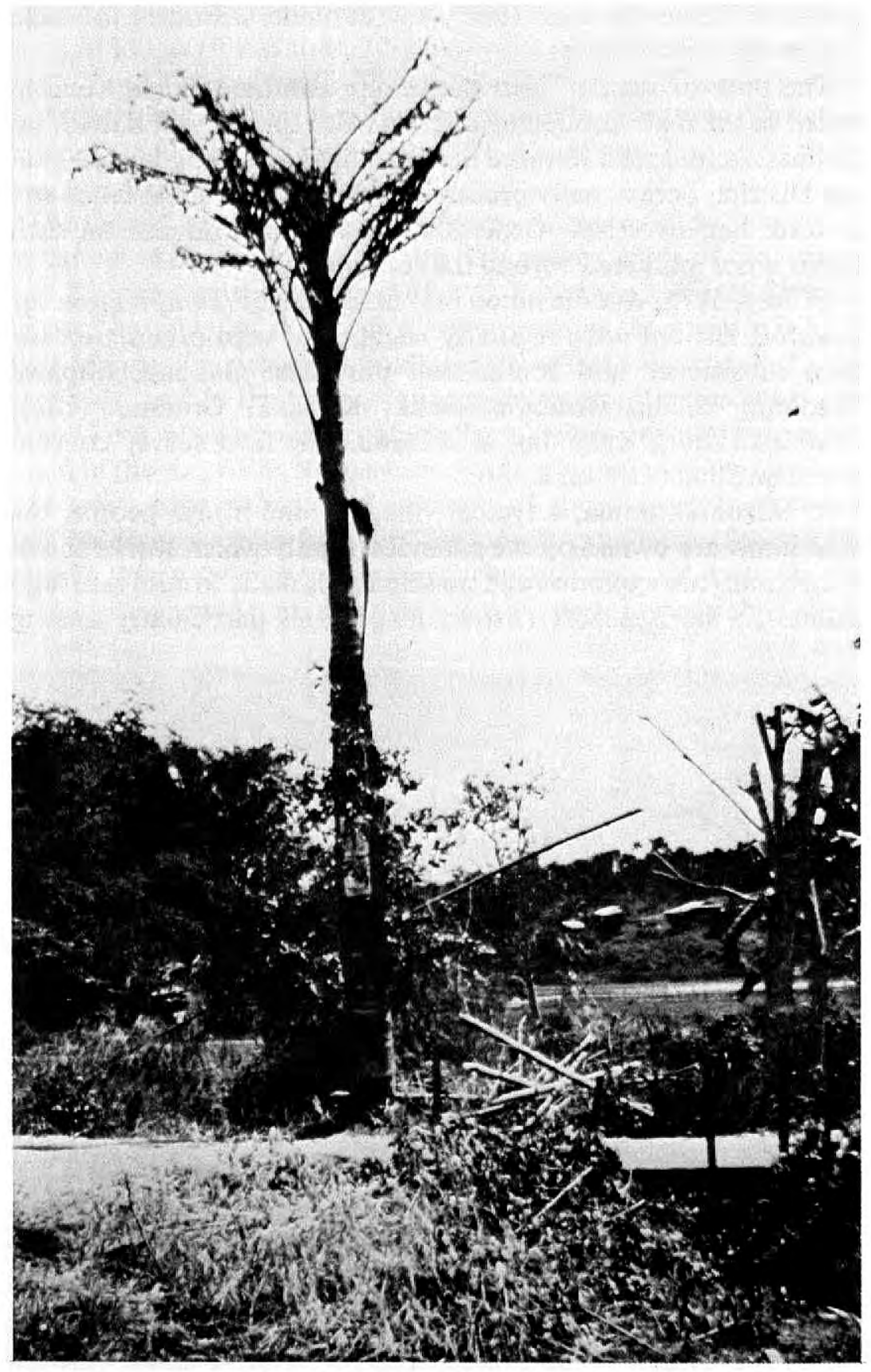

Figure 20. In many parts of Sabah Metroxylon palms are not used. 
smaller landholders, sago is worked by owner-occupiers. On larger holdings landowners may either employ laborers to undertake sago work, or hire workers for a longer term to process sago on an equal-shares-of-the-product basis.

The Bisaya sago production process is summarized in table 7 . Palms, 8 to 10 years of age, which furnish a workable trunk approximately $6 \mathrm{~m}$ long and $0.7 \mathrm{~m}$ in diameter, are selected for felling. A pair of men, working together, fell the palm. Directly thereafter, a number of by-products are taken. Leaves are removed and tied in bundles for use as thatching material (atap), the palm cabbage is cut out for later consumption, and finally the

TABLE 7. The Bisaya Sago Process

\begin{tabular}{|c|c|c|c|}
\hline Products & Task & $\begin{array}{l}\text { Time }^{\mathrm{a}} \\
\text { (min.) }\end{array}$ & $\begin{array}{l}\text { Division } \\
\text { of Labor }\end{array}$ \\
\hline \multirow{16}{*}{ SKINS } & felling & 20 & M \\
\hline & cutting and cleanup & 40 & M \\
\hline & haul to river & 80 & $\mathbf{M}$ \\
\hline & push into river & 12 & M \\
\hline & make raft & 30 & $\mathbf{M}$ \\
\hline & float to processing site & 180 & M \\
\hline & dismantle raft & 5 & $\mathrm{M}^{\mathrm{b}}$ \\
\hline & remove logs from river & 20 & $\mathrm{M}^{\mathrm{b}}$ \\
\hline & skinning & 40 & $M^{b}$ \\
\hline & reduce to battens & 20 & $\mathbf{M}^{\mathrm{b}}$ \\
\hline & transport battens & 64 & $M^{b}$ \\
\hline & check mechanical rasper & 5 & M \\
\hline & rasping & 96 & M \\
\hline & take pith to trampling platform & 30 & M \\
\hline & spread and moisten pith & 288 & M \\
\hline & $\begin{array}{l}\text { trampling } \\
\text { (sedimentation) }\end{array}$ & 240 & $\mathrm{M}$ \\
\hline \multirow{2}{*}{\multicolumn{4}{|c|}{ WASTE }} \\
\hline & & & \\
\hline \multirow{5}{*}{$\begin{array}{l}\text { DRIED FLOUR } \\
\text { BAGGED PRODUCT } \longleftarrow\end{array}$} & flour removal and drying & 240 & F \\
\hline & (sun drying) & & \\
\hline & bagging & 80 & M \\
\hline & $\begin{array}{l}\text { tying/weighing/carrying to } \\
\text { collection site }\end{array}$ & 24 & M \\
\hline & Total Man Hours & minutes) & \\
\hline
\end{tabular}

Notes:

${ }^{\text {a }}$ For 1 Metroxylon palm, $6 \mathrm{~m}$ long, with a $0.7 \mathrm{~m}$ diameter.

b Young boys assist. 


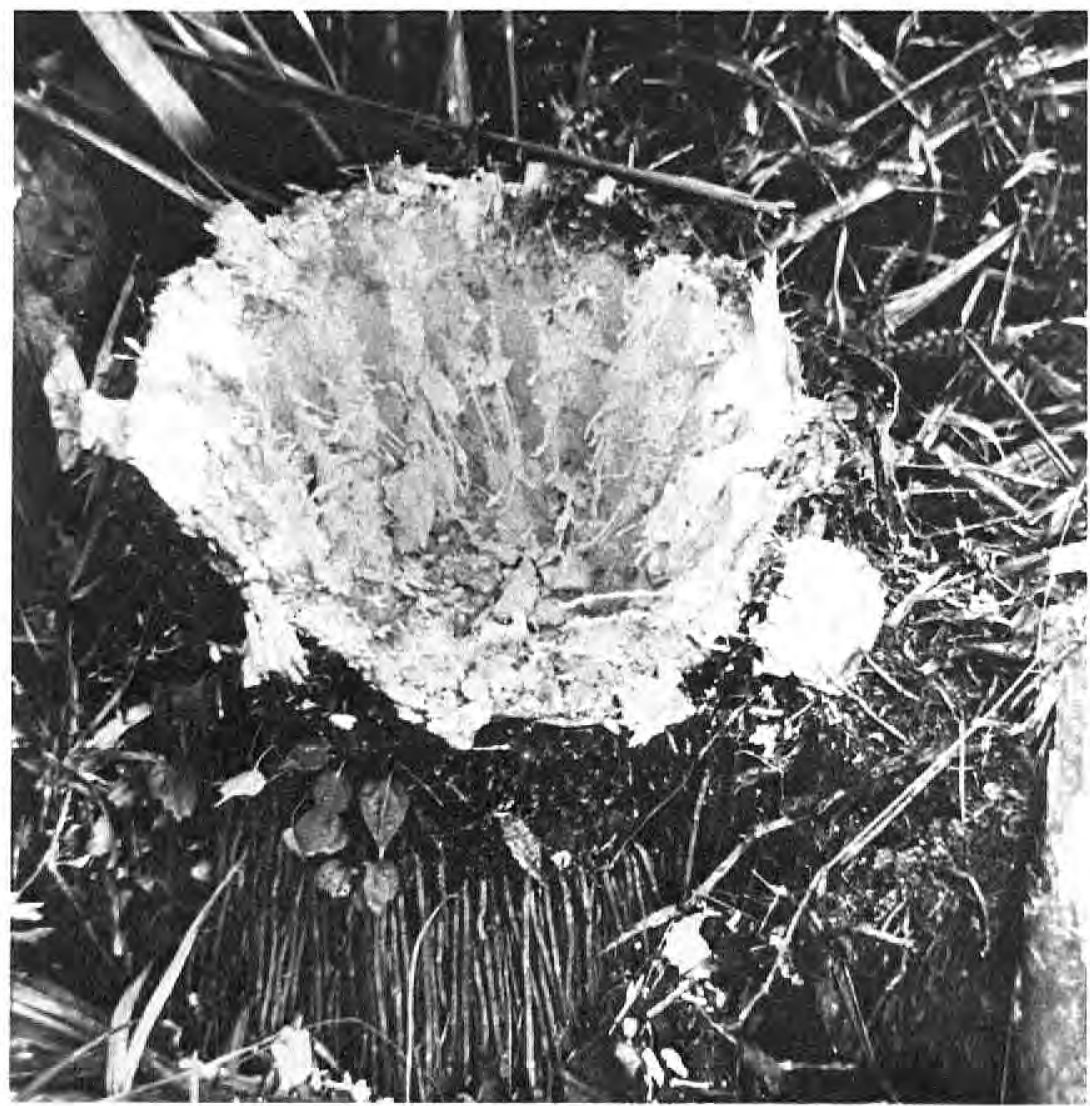

Figure 21. After felling the palm, Bisaya sago makers scoop pith from the stump to be used as chicken feed.

starchy pith remaining in the stump is laboriously scooped out (figure 21). The latter is fed, unprocessed, to chickens. The Bisaya, who hold that "sago is man's bones, rice his flesh, and maize his teeth," insure that no part of the palm is wasted.

After by-products have been removed, thorns, in the case of the spiny form of Metroxylon, are sliced off, and the trunk cut into four sections, each about $1.5 \mathrm{~m}$ in length. Each section is then either hauled to the river bank by water buffalo, or skidded by men along "rails" made from the midribs of Metroxylon leaves (figure 22). The sections are rolled into the river and tied into a raft, then towed by the men, walking in shallow water, to the kampong 


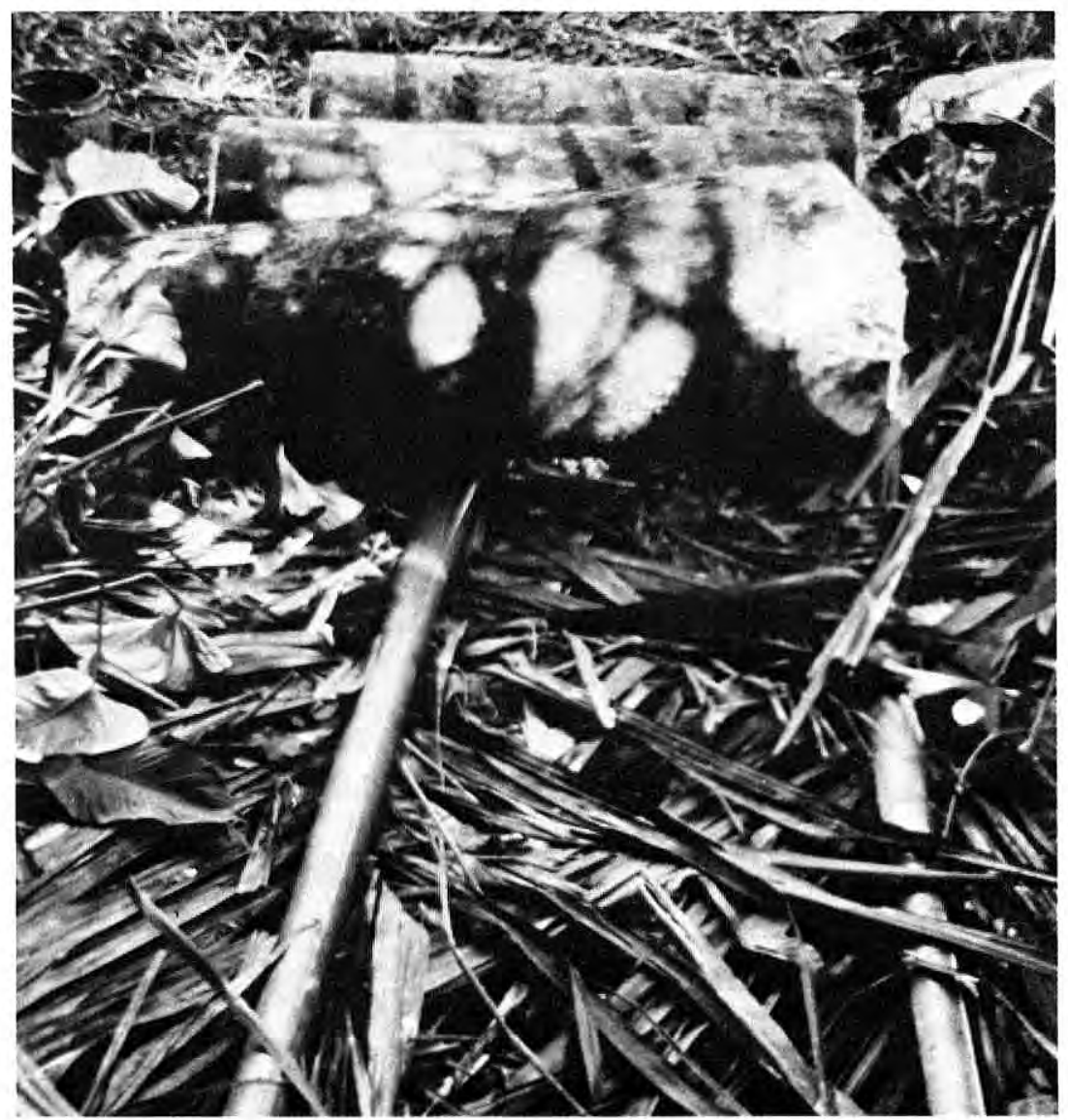

Figure 22. Logs are skidded to a stream over the midribs of palm leaves.

where processing is undertaken. There the raft is dismantled and the logs removed from the water. Unlike the situation in Sarawak, there is no prolonged storage of logs in the river. In Sabah logs are felled and processed according to the work schedule of the trampling phase.

Next the logs are "skinned," strips of the so-called "bark" being pried off with a crowbar (figure 23a). The "skins" are discarded to be nibbled on by domestic animals. The log is then split with an axe into 8 battens, and each batten triturated against a rotary power rasper (Figure 23b).

The rasped pith is bagged and carried to one of the trampling 
Figure 23. Bisaya sago production, Silaun Gramma, Sabah.

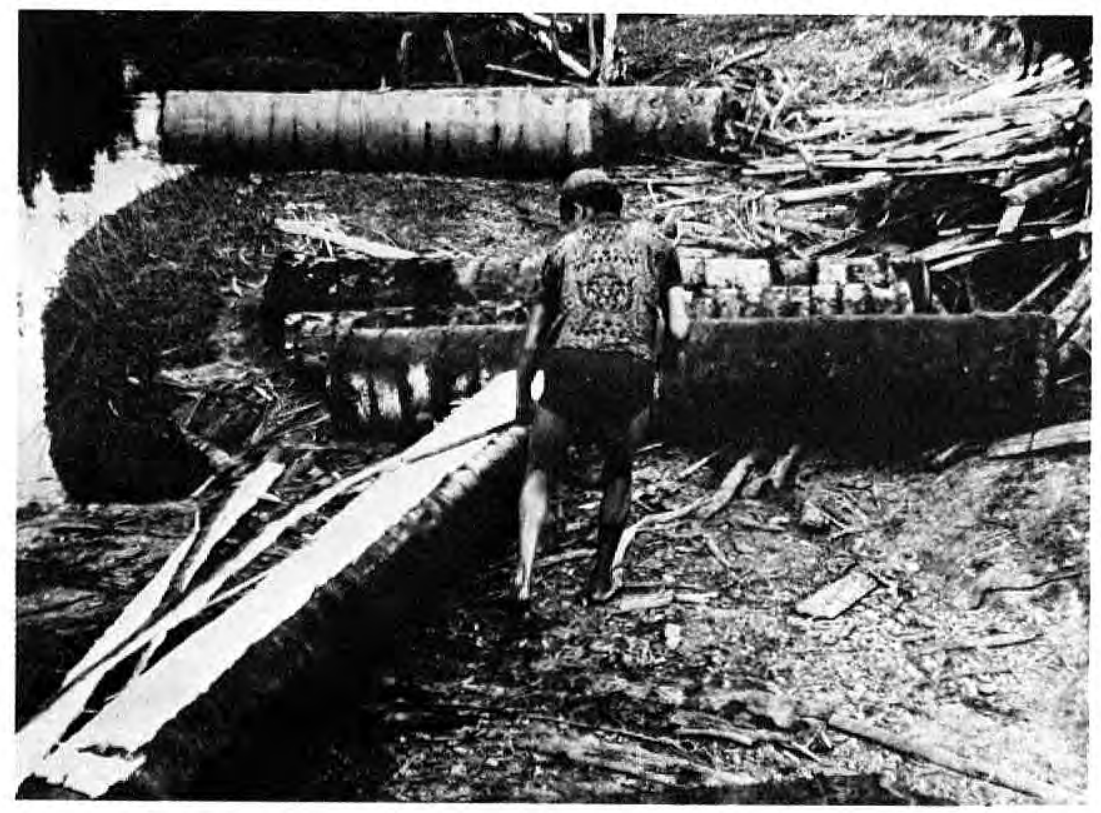

Figure 23a. The "skin"' is removed prior to splitting the logs.

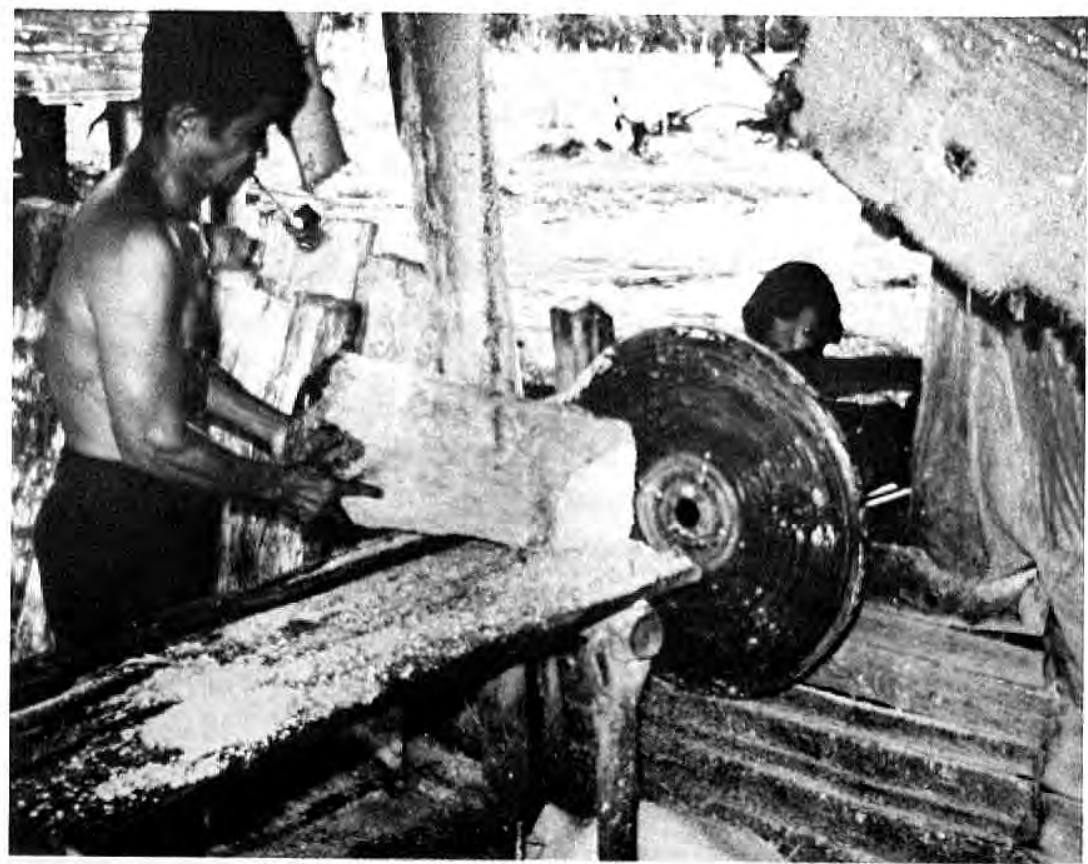

Figure 23b. A rotary rasper is used to reduce the battens to rasped pith. 


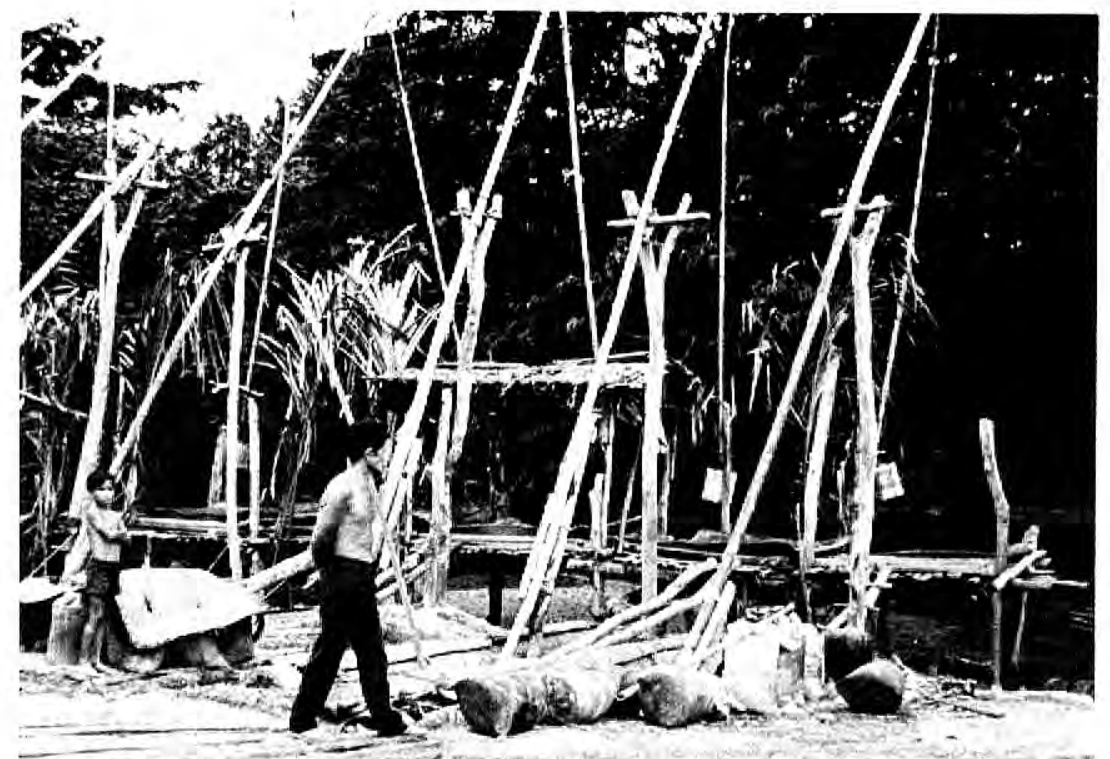

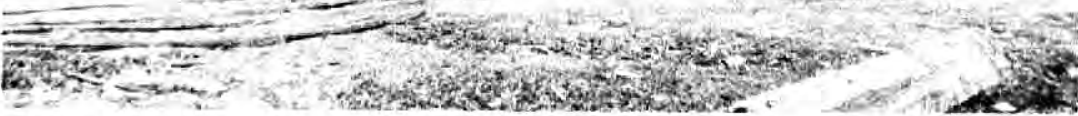

Figure 23c. Trampling platforms line the river bank.

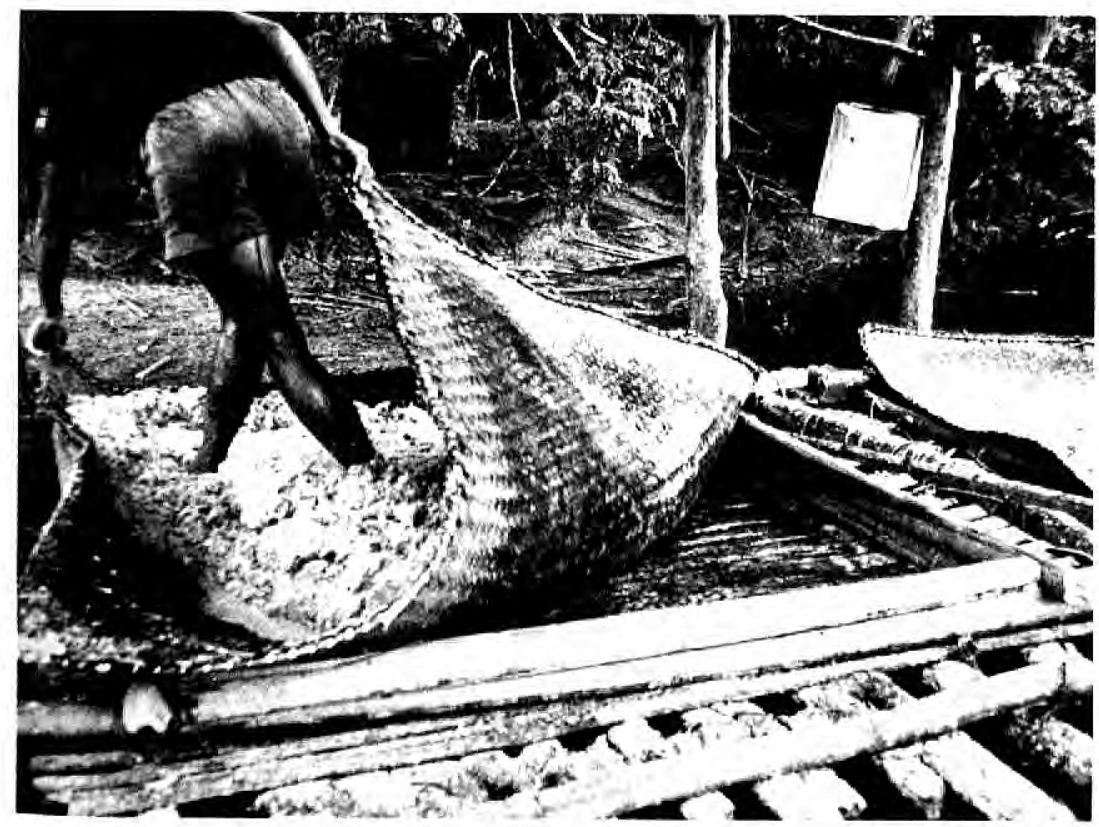

Figure 23d. Prior to trampling, the trampler ensures that the pith is evenly soaked. 


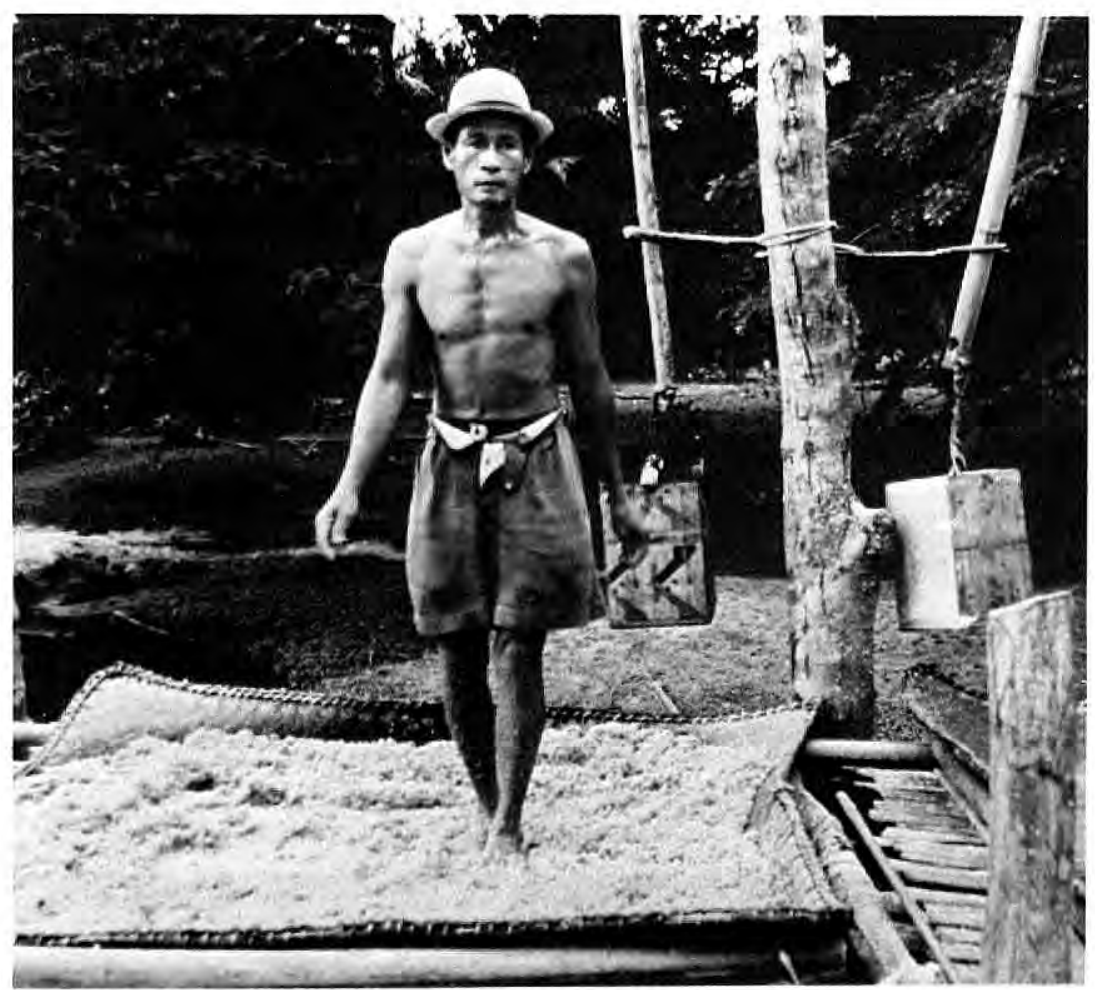

Figure 23e. Among the Bisaya of Sabah, men trample pith to express starch.

platforms which line the riverbank in front of the kampong (figure 23c). The pith from two palm sections is processed together. It is spread on the pandanus mat covering the platform and saturated with river water ladeled on with a sweep. By lifting each of the corners of the mat in turn, the water is sloshed back and forth to assure a thorough soaking of the pith (figure $23 \mathrm{~d}$ ). The pith is then trampled for about 30 minutes (figure 23e). The starch-laden water drips through the mat and enters a conduit leading to the settling tanks (figure 23f). Overflow from the tanks escapes either across the kampong or back into the river.

When trampling is completed the remaining fiber is packed into a can and carried to a waste heap. After a few hours the accumulated starch is scooped from the tanks, packed in a can, and carried to the drying area where it is spread and left to dry in the sun 


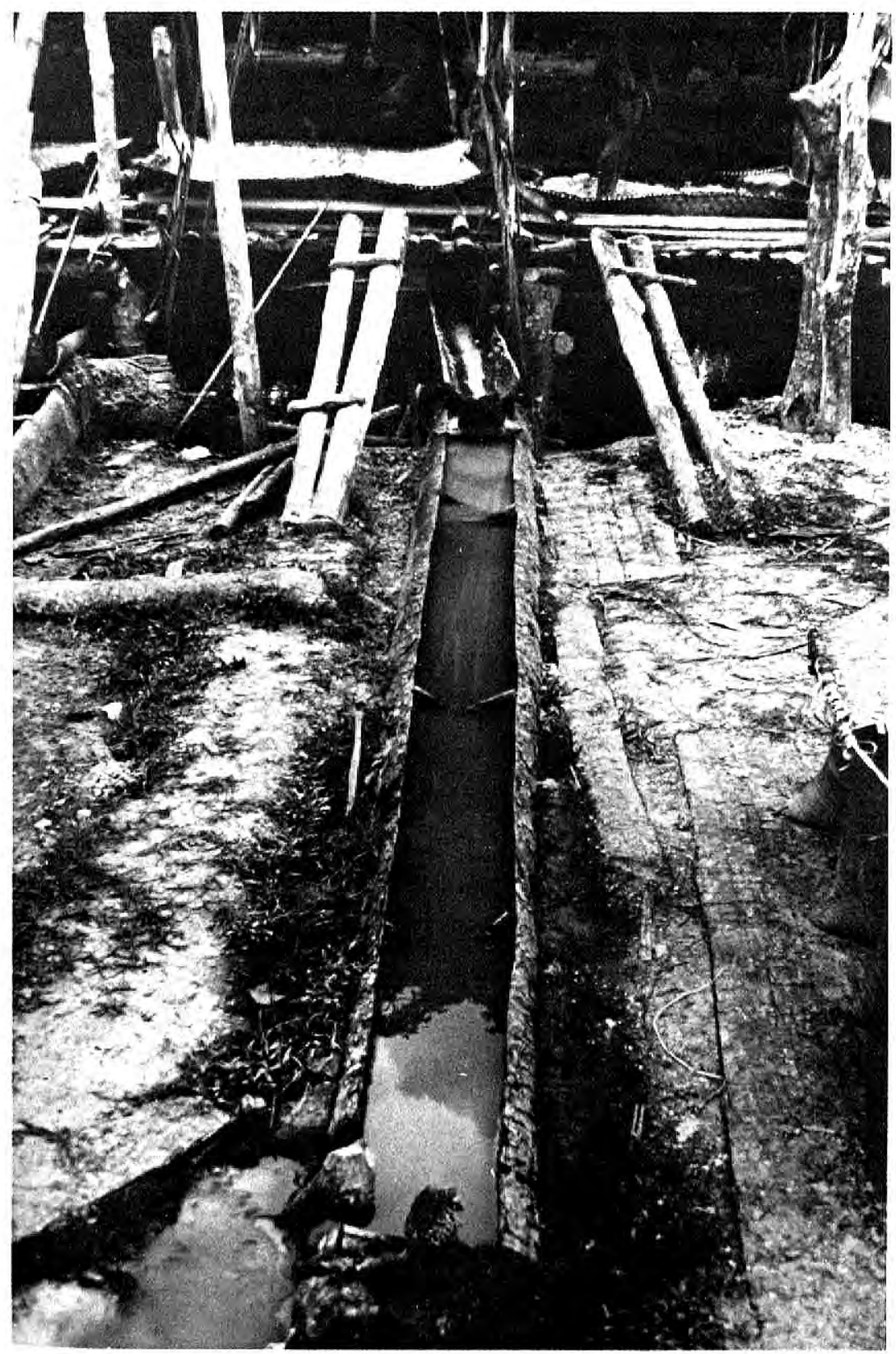

Figure 23f. Here hollow Metroxylon trunks function as sedimentation tanks. 


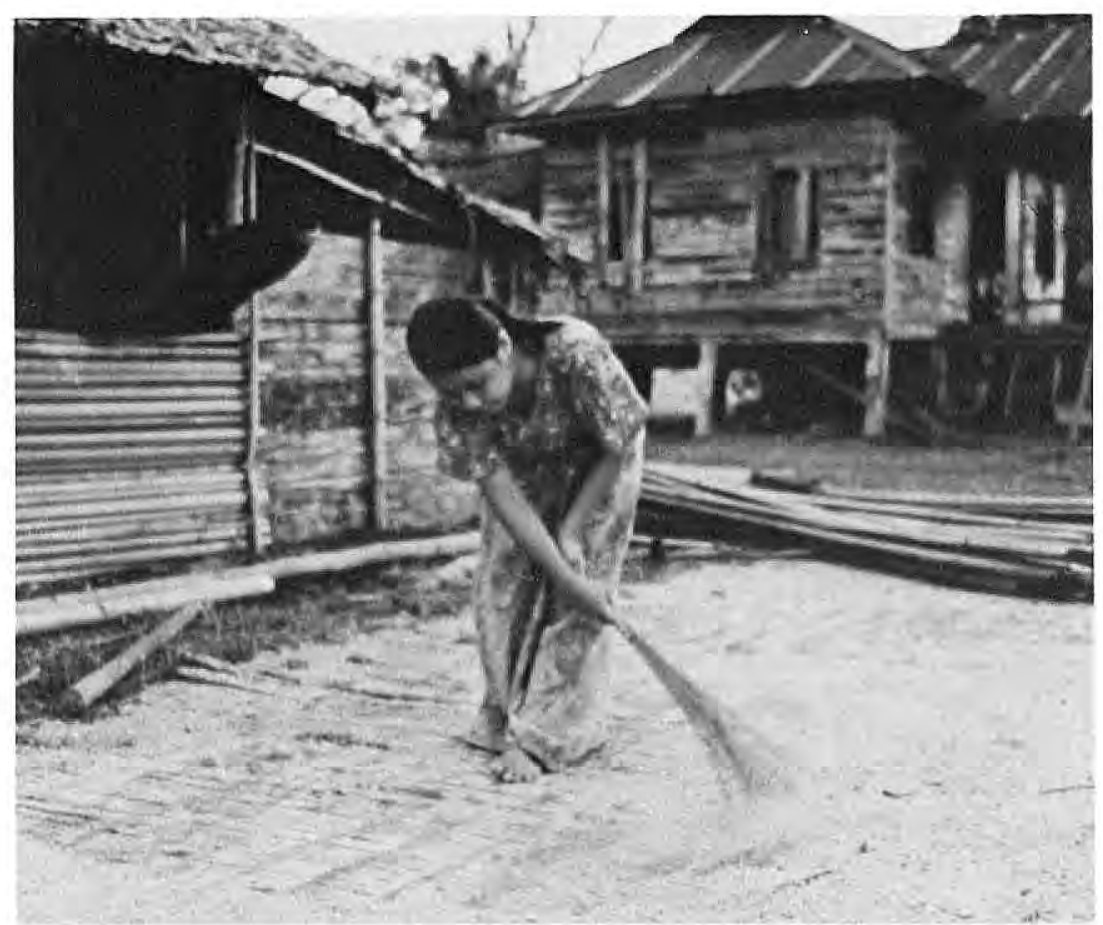

Figure 23g. Bisaya women are responsible for drying.

for one day (figure 23g). The drying area is floored with sections of the barklike outer layer of the sago palm, specifically cut for that purpose. Dried flour is then bagged, weighed, and deposited at a designated spot along the nearest rural road, where it is periodically collected by a contracted truck and taken to a retailer.

In Sabah, the distribution and retailing of sago is done by members of the ethnic groups which produce it, with the exception of shipments destined for points overseas, including Labuan Island, which are handled by Chinese merchants. We have no direct information on the role of Chinese in this overseas trade. Much of the following data was obtained by interviewing a single retailer in the Tuaran market.

Consignments of sago flour ordered by a retailer are sent directly by the producers who contract with a local trucker. A wholesale consignment of approximately $6 \mathrm{MT}$ per month arrives at the market packed in sacks containing about $35 \mathrm{~kg}$ each. The sacks 


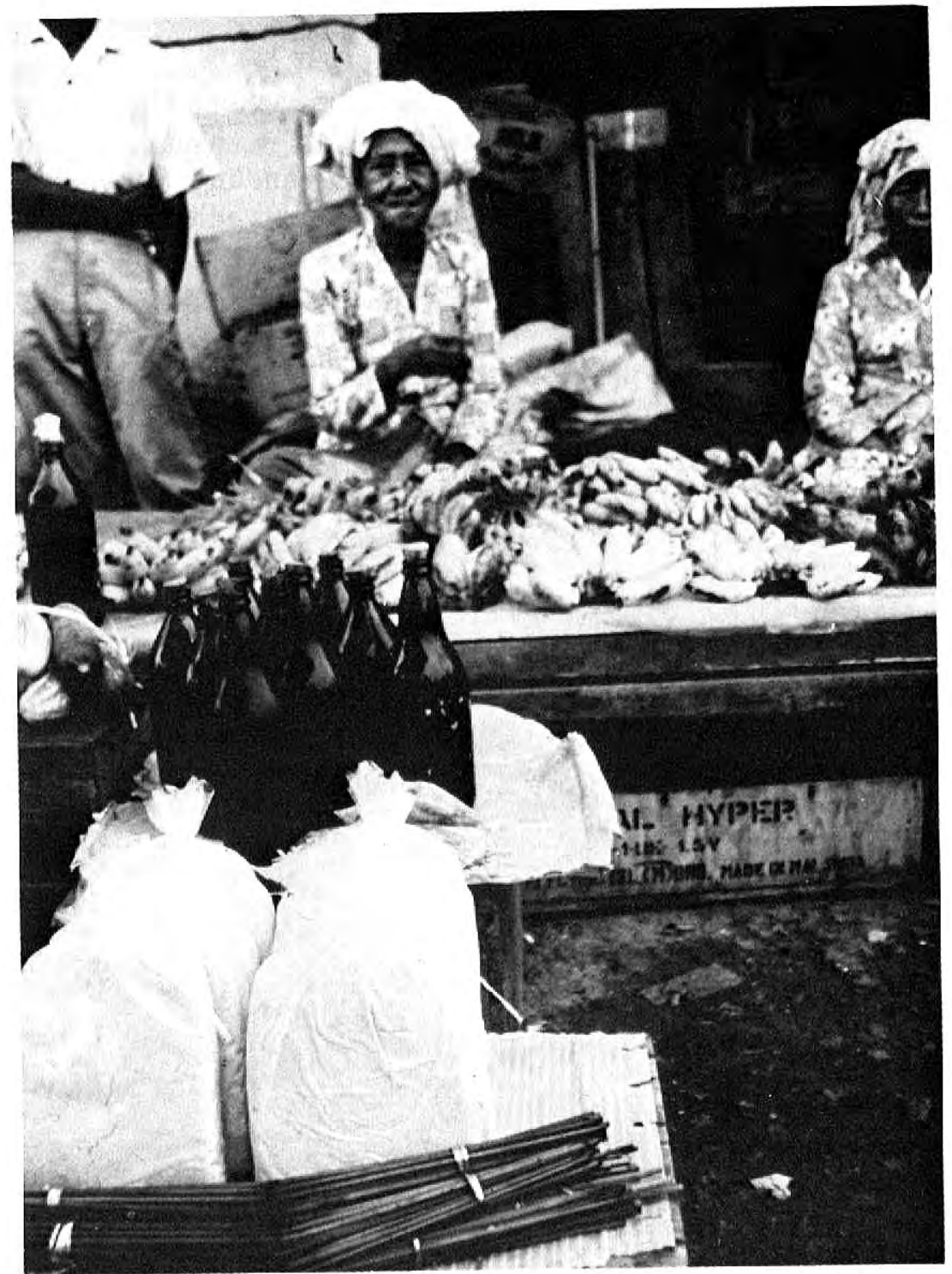

Figure 24. Retailing sago in $1.5 \mathrm{~kg}$ bags in the market at Beaufort, Sabah. 
are delivered by dump trunk to a designated site. Two men are hired to stack the sacks, some of which are immediately emptied into wooden storage boxes. Once in the storage box sago remains moist and edible for up to one year. It is, however, spoiled if subjected to excessive heat. Sago stored in hemp sacks spoils within a month, turning black and becoming infested with insects, as a result of the sacks being punctured during handling. Sago is retailed in small, sealed, plastic bags, and remains edible for up to four months (figure 24).

Retailers do their own weighing and bagging both after the market has closed, and in slack periods during the day (figure 25). Flour is sold in bags containing either 1.5 or $2.1 \mathrm{~kg}$ ( 2.5 or 3.5

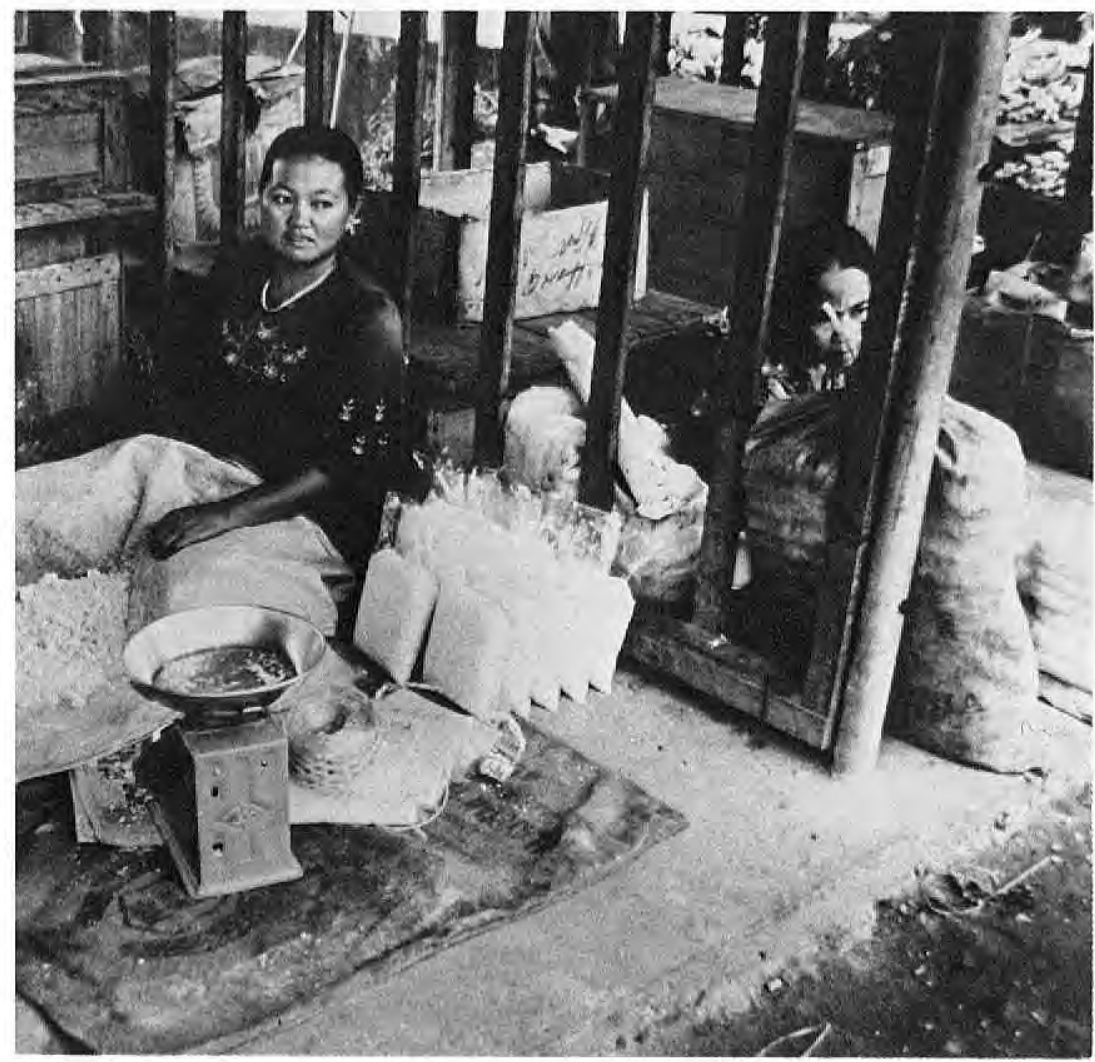

Figure 25. Market women at Beaufort weigh and bag sago in anticipation of the day's sales. 
kati). Only one retailer handles sago besides selling other products, at the Tuaran market. He sells about $120 \mathrm{~kg}$ per day to some 30 to 40 customers. He also wholesales to other retailers who operate stalls in the smaller markets at Kota Balud, Kudat, and Mangatal. Sago refuse and chopped "skins"' are used as pig feed by Chinese farmers and are also retailed.

\section{Brunei}

Commercial sago production, once an important industry in Brunei, nearly ceased in the early 1930 s as a result of low world market prices. By 1935 the industry recovered, when prices increased, and two years later three Chinese-owned factories were in operation, one each on the Belait, Tutong, and Temburong rivers. At the time sago manufacture was a cottage industry which strove

TABLE 8. Brunei: Estimated Production of Sago, 1937-1970

\begin{tabular}{|c|c|c|c|c|c|}
\hline Year & $\begin{array}{l}\text { Area }^{a} \\
\text { (ha) }\end{array}$ & $\begin{array}{l}\text { Production }^{\mathrm{b}} \\
\text { (M.T.) }\end{array}$ & Year & $\begin{array}{l}\text { Area }^{a} \\
\text { (ha) }\end{array}$ & $\begin{array}{l}\text { Production } \\
\text { (M.T.) } \\
\end{array}$ \\
\hline 1937 & & 587 & 1954 & 1,012 & \\
\hline 1938 & 809 & 394 & 1955 & $\ldots$ & 152 \\
\hline 1939 & $\ldots$ & $\cdots$ & 1956 & $\ldots$ & 144 \\
\hline 1940 & $\ldots$ & $\ldots$ & 1957 & $\ldots$ & 105 \\
\hline 1941 & $\ldots$ & $\ldots$ & 1958 & $\ldots$ & $\ldots$ \\
\hline 1942 & $\ldots$ & $\ldots$ & 1959 & $\ldots$ & $\ldots$ \\
\hline 1943 & $\ldots$ & $\ldots$ & 1960 & $\ldots *$ & $\ldots *$ \\
\hline 1944 & $\ldots$ & $\ldots$ & 1961 & $\ldots{ }^{*}$ & $\ldots *$ \\
\hline 1945 & $\ldots$ & $\ldots$ & 1962 & $\ldots{ }^{*}$ & $\ldots{ }^{*}$ \\
\hline 1946 & $\ldots$ & $\ldots$ & 1963 & $142^{*}$ & $363^{*}$ \\
\hline 1947 & 818 & $\ldots$ & 1964 & $142^{*}$ & $370^{*}$ \\
\hline 1948 & 828 & $\ldots$ & 1965 & $160^{*}$ & $59^{*}$ \\
\hline 1949 & 854 & $\ldots$ & 1966 & $671^{*}$ & 966 \\
\hline 1950 & 876 & $\ldots$ & 1967 & $672^{*}$ & 967 \\
\hline 1951 & 886 & $\ldots$ & 1968 & $673^{*}$ & 1,037 \\
\hline 1952 & 913 & $\ldots$ & 1969 & $675^{*}$ & $1,012^{*}$ \\
\hline 1953 & 1,000 & 233 & 1970 & $682 *$ & 675 \\
\hline
\end{tabular}

SOURCES:

State of Brunei, Annual Reports, for 1937, 1947, 1948, 1949, 1950, 1951, 1952, 1953 , 1954, 1955, 1956, 1957, 1958, 1959, 1966, 1967, 1968.

* Director of Agriculture, Brunei, personal communication. Notes:

... No data available.

a Converted from acres and rounded.

${ }^{\mathrm{b}}$ Converted from pikuls $(1$ pikul $=60.48 \mathrm{~kg})$ and rounded. 
to satisfy domestic needs, and only small surpluses of low-grade flour were sold to the factories for further refining. Prior to World War II the colonial administration opened a Sago Demonstration Station at Kuala Balai, on the Belait River, in an attempt to teach improved methods of palm cultivation (State of Brunei 1938:22).

During the war sago production lapsed into an exclusively cottage industry status, and remained at low levels through the early 1950s, producing only wet sago and pig feed for local use. By 1958 , four mills had been constructed in the Kuala Belait District and exports revived (State of Brunei 1958:34), although two years later the industry was described as ". . . virtually stopped, and very little, if any, sago flour was manufactured" (State of Brunei 1960:33). Wet sago, however, was still produced, and used locally to feed pigs and poultry. In 1964, machines for extracting sago flour were introduced into the Kuala Balai area, and in the Tutong District a mechanized grater was introduced to produce pig feed (State of Brunei 1966:45). Apparently the status of the industry in Brunei has remained unchanged in the last decade. Brunei's sago production is summarized in table 8 .

\section{Sarawak}

The most complete information on commerical sago production is available for Sarawak. Prior to British intervention Sarawak was an important sago exporter. Low (1848:38-39), after the Raj was established, reported the export of large quantities of "rough sago" to Singapore from areas occupied by the Melanau tribe. In the early 1850 s immigrant Chinese merchants established processing mills in Kuching, but development of the trade was soon hampered by an insurrection in the producing regions. After the region was ceded to Brooke in 1861 and peace restored, the industry, organized at first mainly by immigrant Malay and later by Chinese traders, began to expand. Exports grew apace, from almost $9,000 \mathrm{MT}$ in 1887 to $14,732 \mathrm{MT}$ (1897), and 22,353 MT (1909). During the 1930s exports averaged 21,300 MT per year.

Production for export came to a virtual standstill during the Japanese occupation, hence, by the time the occupation ended, a considerable starch reserve had accumulated in the palm gardens. Accelerated felling, in order to take advantage of the high price of sago, followed the end of hostilities. But commercial sago produc- 
tion soon declined, despite high prices at the beginning of the 1950 s, owing to widespread over-felling during the boom years. Then, in 1953, prices fell dramatically, when the principal British user of sago starch switched to the use of cornstarch (Morris $1964: 8$, cited in Jackson 1968:107). The industry in Sarawak was almost ruined, and flour exports dropped steadily to about 10,000 MT in 1955.

Despite falling prices, production recovered after 1955, reflecting principally the emergence of new markets. In 1963, Japan supplanted the United Kingdom as the major purchaser of Sarawak's sago, buying low grade flour for the monosodium glutamate industry. Today the Sarawak sago industry is severely depressed, a condition which has led to major changes in the traditional social and economic system of the Melanau. Sago starch is no longer a dominant export of Sarawak by value. Nevertheless, the state remains the leading international source of sago flour, and its production still involves thousands of people.

Melanau Cultivation and Processing. The cultivation of sago palms is best developed in west-central Sarawak, in the vast area of contiguous equatorial peat swamps. There it is cultivated by the Melanau people, and grown on small farms individually owned by men or women. It is not a plantation crop. Morris (1953) described the cultivation and processing in considerable detail.

Desirable sites for making a sago garden are those with loam soils, on a stream of sufficient size for dugouts to tow palm trunks to a mill. Swamps make overland transport difficult, and sites away from streams are less desirable. The Melanau also cultivate Metroxylon on a variety of freshwater wetland soils, including deep peat and periodically flooded sites with an underlying hardpan. Starch yields are greater on loam soils; on problem soils, such as periodically flooded land with a clay pan, botanical maturity is delayed by some 10 years and yields may be less. First crop yields are best; subsequent plantings produce smaller palms, and yields decline unless proper spacing is maintained and weeding practiced, in which case the yields are consistently high. Some gardens have a continuous eighty-year history of cultivation.

Establishing a sago garden involves the arduous task of slashing and burning dense tropical forest. One man working three days per week can clear and plant 1.6 to 2.0 ha per year. Clones are obtained at little or no cost from friends and relatives, stored under 
moist conditions, and periodically planted throughout the year. The clones are set out in parallel rows at a spacing interval of $7 \mathrm{~m}$, too close for optimal growth, but predation of young plant shoots by monkeys, honey bears, and pigs reduces field density. After planting sago, many Melanau cultivate two successive catch crops within the palm garden. If weeds are controlled and predator attacks minimal, palms become well-established after 4-5 years and, if planted on loams, mature in about 15 years. Palms are harvested over several years; the field population is maintained by suckering from the base of the felled palms.

Village processing was described by Morris (1953) on the basis of a two-year field study of the Melanau people who, at that time, depended almost entirely on the sale of wet sago. In 1947, Morris found that about 4,000 Melanau, together with some 1,350 Chinese, were involved in sago production along the Oya River. Morris described Melanau villages along the Mukah, Igan, and Oya Rivers as ribbon settlements whose most distinctive feature was small sago-trampling platforms mounted over large troughs, built either on the river bank or on a raft of logs anchored offshore.

Palms are usually felled by men and cut into $1 \mathrm{~m}$ sections which are then skidded on the midribs of Metroxylon leaves to a stream and formed into rafts for floating either to the owner's dwelling for preliminary processing or directly to a rasping mill. At the preliminary processing site, the outer layers are stripped from the trunk, which then is split into four or five small battens suitable for rasping. Formerly battens were held stationary on a small raised bench and rasped by drawing a nail-studded board back and forth across their surface.

The mechanical rasper, introduced to the region in 1947, consists of a circular nail-studded wheel driven by a small engine. This innovation altered the traditional sexual division of production labor. Felling, transporting, and hand rasping formerly occupied the men for about the same amount of time as trampling and sedimentation took the women. Mechanized raspers, which can process about 100 logs ( 15 palms) per day, reduced the demand for male labor.

Next, the rasped pith is taken to a household trampling platform. A typical platform is about $3 \mathrm{~m}$ square, and consists of an open-walled shed roofed with palm thatch. It is constructed with a raised floor so that a canoe or floating trough can be guided be- 
neath to catch the starch-laden water. The platform is floored with wooden slats covered with a tightly woven pandanus mat.

A supply of pith is deposited next to the platform, and a trampler sets a quantity of pith on the mat, ladles on river water, while stirring the mixture with her foot. She lifts each corner of the mat to distribute the water evenly and to remove the surplus, then proceeds to trample the moistened pith. Trampling is generally a female task.

As the starch-laden water is expressed, it filters through the mat and drips into the trough below. Drip boards direct the water through a coarse filter designed to prevent the entry of fibrous matter into the starch. The exhausted pith is discarded when the water draining into the trough runs clear.

Some platform-owning Melanau households process other people's rasped pith, working on shares with owners of the gardens. Proceeds from the sale of wet sago are shared between the owner of the palms and the processor of the stems. When an owner fells, transports, and pays for rasping he keeps two shares and the trampler receives one. Normally working groups comprise husbands and wives, with others joining as work or illness dictates. An average of 8 palms per platform per month was processed in the village of Medong in 1950. That volume required 22 days of trampling.

At the time of Morris's survey sago production was apparently limited less by stem availability than by the trampling time required. Income was divided on shares if outsiders were involved, thereby substantially reducing a trampler's earnings. When a trampler's household owned a sufficient number of producing palms, the income from production and sale of wet sago was considerably above subsistence level for a family of four. Working on shares did not yield a living wage, and earnings had to be supplemented by other income. Most households did not have enough harvestable palms and indebtedness to Chinese middlemen was usual. That situation sometimes led to indentured worker status, with households selling their sago to merchants at discounts of 5 to 20 percent.

Among the Melanau, wet sago was sold to Chinese middlemen, traders who also supplied producers with consumer goods. The trader reprocessed the sago in order to meet government export standards. After drying, the flour was bagged and stored for ex- 
port. Sago was subject to price fluctuations, which could have financially destroyed the business of a small merchant who had accumulated it at a high price and who later was forced to sell at lower prices in order to satisfy indebtedness to his own supplier of goods. The local Chinese middleman was, in turn, at the mercy of bigger merchants in the ports and in Singapore. Some Chinese merchants abandoned the sago trade, claiming that the cost of processing and transportation provided no profits at normal prices unless there were enough indebted suppliers selling at a discount.

As a result of declining prices during the 1950s and 1960s, the severely depressed economic condition of the Melanau settlements deepened as the industry became concentrated in a few factories, which required a small labor force, thereby replacing the laborintensive cottage industry. When prices were high, during the immediate post-war years, mills near villages introduced powerdriven rasping machinery; then, as prices declined in the mid1950 s, the mills began to process wet flour. Melanau still own palm gardens, but now their role in sago production is limited to tending, felling, and transporting the palms. Some garden owners sell entire immature crops to the mills, and Morris (1964:4) predicted that "it can only be a question of time, unless the process is checked, before sago gardens are sold in quantity to the owners of refineries, and the industry comes to be based on the plantations in the hands of a few factory owners,"

Preliminary results of on-going research appear to indicate that Morris's prophecy is being fulfilled. The changed structure of the industry has had a drastic impact on the Melanau community. The cottage industry has virtually ceased, a major source of income has disappeared, and household credit has been withdrawn by mill owners. Most people are now underemployed, although some men work as laborers in commercial mills, and many younger males have sought higher wages in the logging industry during times of low sago prices. Women, who have lost their traditional economic role, have been hardest hit, although they continue to process small amounts of sago for household use and for village commerce. Another consequence of the changed structure of the industry has been the attempt to diversify local agriculture.

Changes have also taken place in the Melanau diet. Many tribesmen now buy rice, despite its being more expensive than 
sago. Younger people prefer rice, and regard sago as only a supplementary food. Older folk and the poor people continue to depend on sago, which is eaten with rice and fish.

At the present time the Sarawak sago industry is concentrated in approximately 100 mills, owned by Chinese or Melanau. Of the total, 23 mills are located in the Dalat area, along the Oya River. There is considerable variation in mill size. In that area 9 small mills process palms from their owners' gardens by the traditional foot-trampling method, and sell the product for domestic consumption.

The remaining 14 mills along the Oya, each of which produces about $150-300 \mathrm{~kg}$ of flour per month, are commercial operations. All logs processed at Chinese-owned mills are purchased, because outsiders are forbidden to own land in tribal areas. At the Melanau-owned mills, because sufficient palms are not available from the owners' fields, most palms are also purchased. Larger mills do not purchase partially processed sago from smaller mills.

The commercial mills (table 9) have mechanized many of the operations with machinery made within the factory. Most such mills refine sago only into second-grade flour. These mills purchase mature logs from a grower who is responsible for felling and transporting them to the river and forming them into a raft. Palms growing relatively close to streams are transported whole to the mill. Sometimes the grower also transports the logs directly to the mills, but where relatively large rafts are involved, the mill owner arranges for a launch to collect and tow them in. At the factory logs are stored in the river until processed (figure 26). Kept immersed, the trunk can be stored for several weeks or longer, since microbial action at the ends seals off and prevents deterioration of the interior.

When ready for processing, logs are hauled from the river, cut into $1 \mathrm{~m}$ sections, if they are entire trunks, and the so-called "bark" removed. The sections are then split into battens and rasped. The rasped pith drops beneath the rasper and is mixed with water to form a slurry. That in turn flows over a power roller fitted with small, wooden blocks which express the starch by maceration. The wet macerated material then passes onto a fine power-sieve which captures the waste. The starch-laden water passes into sedimentation tanks, where the starch is allowed to settle out. The water is drained out after the starch has settled. At 
TABLE 9. Commercial Sago Mill Operations, Dalat, Sarawak

Products

Operation

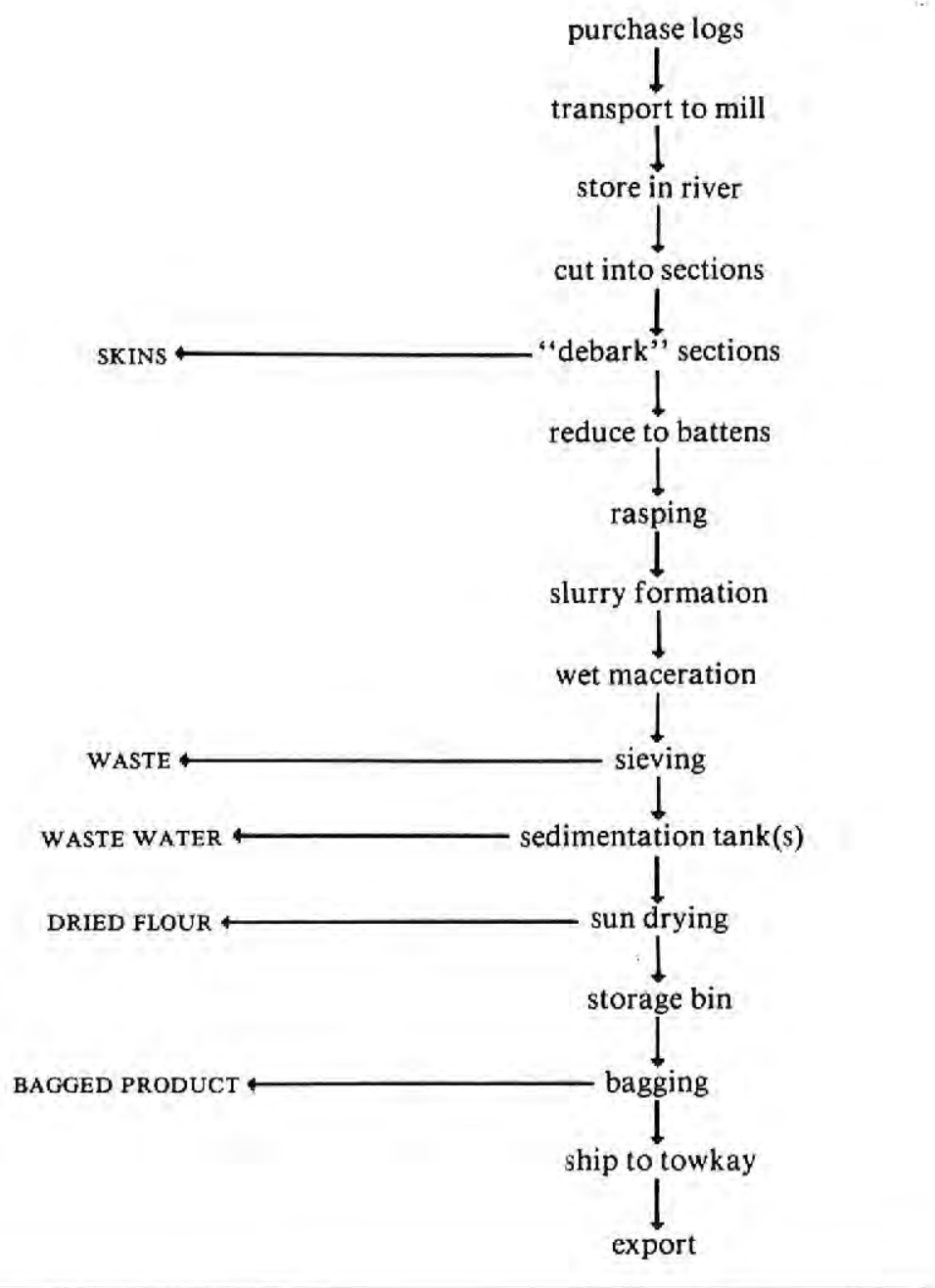




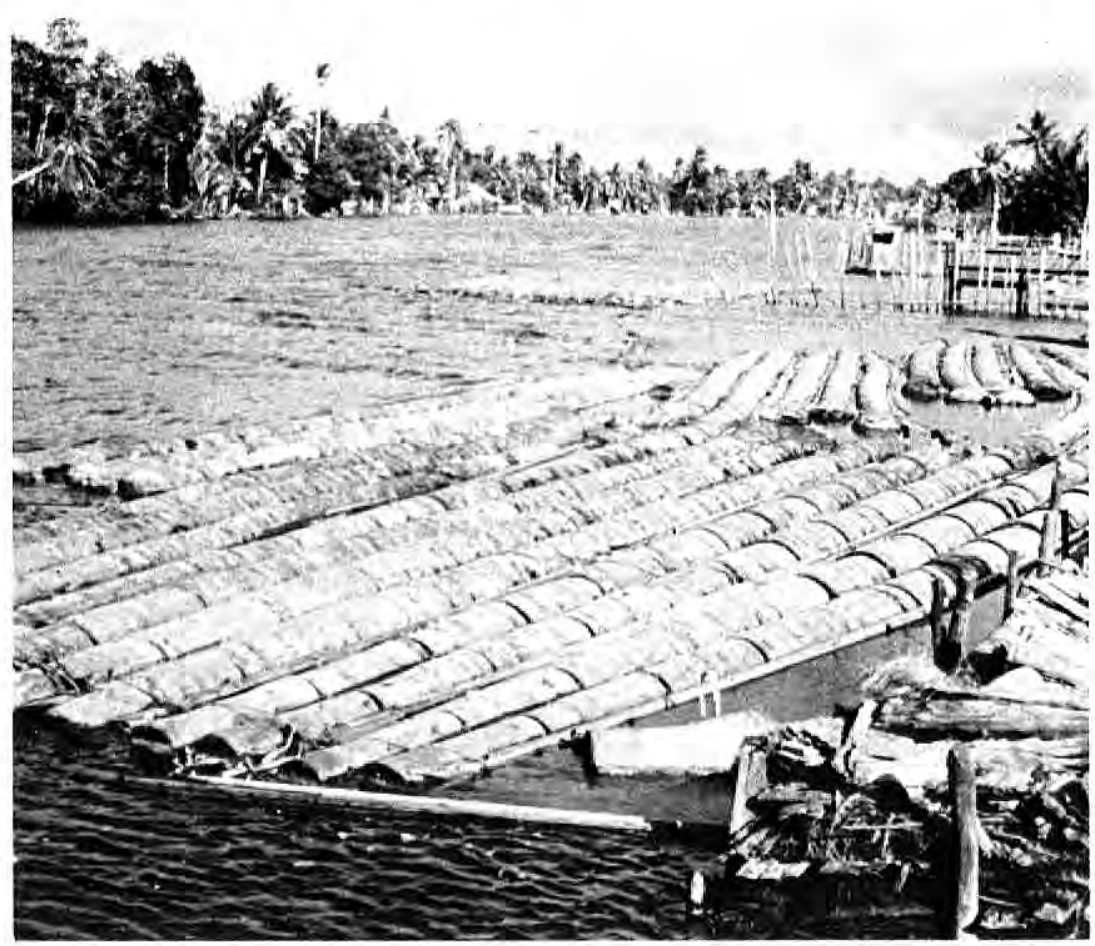

Figure 26. Logs are stored in the River Oya at Dalat, Sarawak, until they can be mechanically processed.

Chinese-owned factories the water is passed through several tanks to maximize sedimentation. Finally, the flour is sun-dried in the traditional way and stored in sacks until shipped to a Chinese trader (towkay). Each commercial miller is tied to a particular towkay in Sibu. To attain a higher grade product, the flour may be washed and sieved several times before shipping. The towkays purchase most sago processed in the Dalat area and ship it directly to Japan, without further refining.

Planned Development of the Sarawak Sago Swamps. Equatorial freshwater peat swamp environments are ill-suited to agricultural development based upon the cultivation of crops familiar to most planners. But the swamps are the natural habitat of $\mathrm{Me}$ troxylon, which, together with the products of fishing, hunting, and forest gathering, may have sustained tens of thousands of Melanau and other ethnic groups for millennia. Despite the relatively recent addition of rice and other starches to their diets, it is 
likely that sago will continue to provide the main subsistence foodstuff of these zones for the forseeable future.

Several major difficulties have long prevented the rational industrial use of palm sago. Foremost among these has been, historically, the widely fluctuating prices commanded by sago in world starch markets. In large part this has persisted because of both the inconsistent quality and unreliable supply of Sarawak sago starch. Modern industrialization of production, however, as exemplified by Sarawak Chemical Industries, may resolve the problem.

A second major difficulty arises from uncontrolled, large-scale felling over many decades without any replanting programs. This has resulted in a diminished supply of logs. Moreover, usable stands are now found farther from suitable waterways. On the average it now takes two days for a man to move a palm from the felling site to a stream. The problem of access has led to an underutilization of mature palms located far from the mills, and, at the same time, an overutilization of immature stands near the mills. Hence, in terms of development planning, transportation cost, rather than soil characteristics, is regarded as the principal factor delimiting areas suitable for sago cultivation. Because of these difficulties increasing emphasis has been placed on the logging of hardwoods, and on the cultivation of other crops. These activities are seen as potentially dangerous alternatives in the balanced swamp environment where the long-term impact of uncontrolled cutting and clean-field cultivation is unkown.

Chronic economic depression, coupled with under- and unemployment in the sago-producing areas during the last few years, has prompted the Government of Sarawak to make ecological and socioeconomic surveys of sago-producing zones and to propose two complementary schemes aimed at the rejuvenation of the industry. The schemes involve sago planting and the digging of a network of small canals for transporting logs from the growing areas. The Sarawak government has noted that rural development in the sago-growing areas, must, to be self-sustaining, use crops and associated technologies culturally imbedded in the area: "The fact that this [sago] is a crop already so familiar to the . . . people, virtually assures the success of implementing the proposed Sago Planting Scheme" (State of Sarawak n.d.:2). This factor is generally overlooked in most development proposals. 
The Planting Scheme. This scheme will assist owners of sago stands to rehabilitate their holdings after extracting mature palms by scientifically replanting and cultivating. The goals of the scheme are: to promote intensive agriculture; to achieve greater economic returns by using renewable natural resources more rationally; to establish sago plantations in central locations and intensify their cultivation in order to supply and support agroindustries; and to develop new crop assemblages for the swamp zone based on the planting of yam, cocoyam, annatto, cassava, pineapple, and banana as intercalary catch crops. Underlying such goals is the broader objective of raising rural incomes and levels of living in order to reduce rural-urban migration.

Participating in the scheme will be: owners of registered land; owners of existing sago holdings; or natives occupying land under indigenous personal law, providing the land can be certified as suitable for sago cultivation. Eligibility to participate is also limited to those owning a total of between 6 and 12 ha of land. Holdings are to be planted at a density of 300 palms per ha, at intervals of $10 \mathrm{~m}$, and at a rate of 2 ha per year. It is estimated that each 2 ha stand will need replanting at 18 to 20 year intervals.

Holdings located on interfluves between tributaries and the main rivers are to be grouped into blocks of 24 to 240 ha. Grouped thus, owners of the holdings will be able to pool labor more effectively for constructing transportation canals. Development of the first block was scheduled to begin in 1976.

A subsidy is to be provided to each participant over the initial three-year period. Of the total, 40 percent is to be a cash subsidy for clearing and preparation of sites in the first year, and weeding and maintenance in the second and third years; an additional 40 percent is to subsidize canal construction; and the remaining 20 percent is to cover establishment costs during the second year. Suckers for planting are to be provided by the owner of the holding. In lieu of a cash subsidy for establishment, such items as tools and herbicides can be issued.

Construction of Canals. The physical difficulty of removing felled palms to processing sites is regarded by farmer and agricultural officer alike as the major impediment to development of the sago industry. To reduce labor requirements a number of canals will be dug to enter the sago blocks from various tributary streams. Besides facilitating transportation, the construction of 
the canals will reduce the time between cutting and immersion, thereby reducing the incidence of trunks being attacked by microorganisms and mammals. So great is the perceived need for such canals that the inhabitants of Balan village have, on their own, excavated a canal which extends nearly $3 \mathrm{~km}$ into their sago groves.

Canals are to be dug approximately $1.6 \mathrm{~km}$ apart. Since logs now must be hauled between 2.5 and $3.0 \mathrm{~km}$ to a stream, the overland transportation will be greatly reduced. Closer canal spacing is not recommended because it might result in excessive drainage, with unknown effects on the palm stands. Inexpensive gates may be built at the canal-river junctions as a further precaution against excessive drainage. To coordinate these developments, and to conduct research on sago palms, a specialized agricultural experiment station will be established at Dalat.

The planting scheme and canal construction, along with the application of research results will contribute greatly to the resuscitation and reorganization of the Sarawak sago industry.

Modern Industrialization. A modern factory located by the river on the outskirts of Sibu, specifically designed to process palm stem starch as a high grade industrial raw material, began operation early in 1975. Several factors dictated a plant location in Sibu rather than closer to the sago-producing zone, including the infrequency of flooding, a more reliable power supply, and, particularly, a source of clear water. Water in the lowland areas has a reddish tinge which discolors the starch and renders it less marketable.

The Sarawak Chemical Industries factory, a joint venture between the private sector and the Sarawak Economic Development Corporation, was established to profit from future sago developments. With an operating capacity of about 2,000 MT of refined sago flour per month, the plant now operates at only 25 percent of capacity, owing to an insufficient supply of raw material.

Supplies of wet, crudely refined sago flour are obtained from some 20 regular Chinese, Melanau, and Malay suppliers who are indebted to the company in the traditional manner. Raw sago is shipped from Dalat, Mukah, Balingau, Matu, Saratok, and Posa in small vessels which tie up at the factory wharf. At present only "super" grade refined starch is produced. Factory waste is not regularly sold, as it cannot yet command a regular market. The sequence of stages in the factory process is summarized in table 10. 
Table 10. Production Process in a Modern Industrial Sago Refinery, Sibu, Sarawak

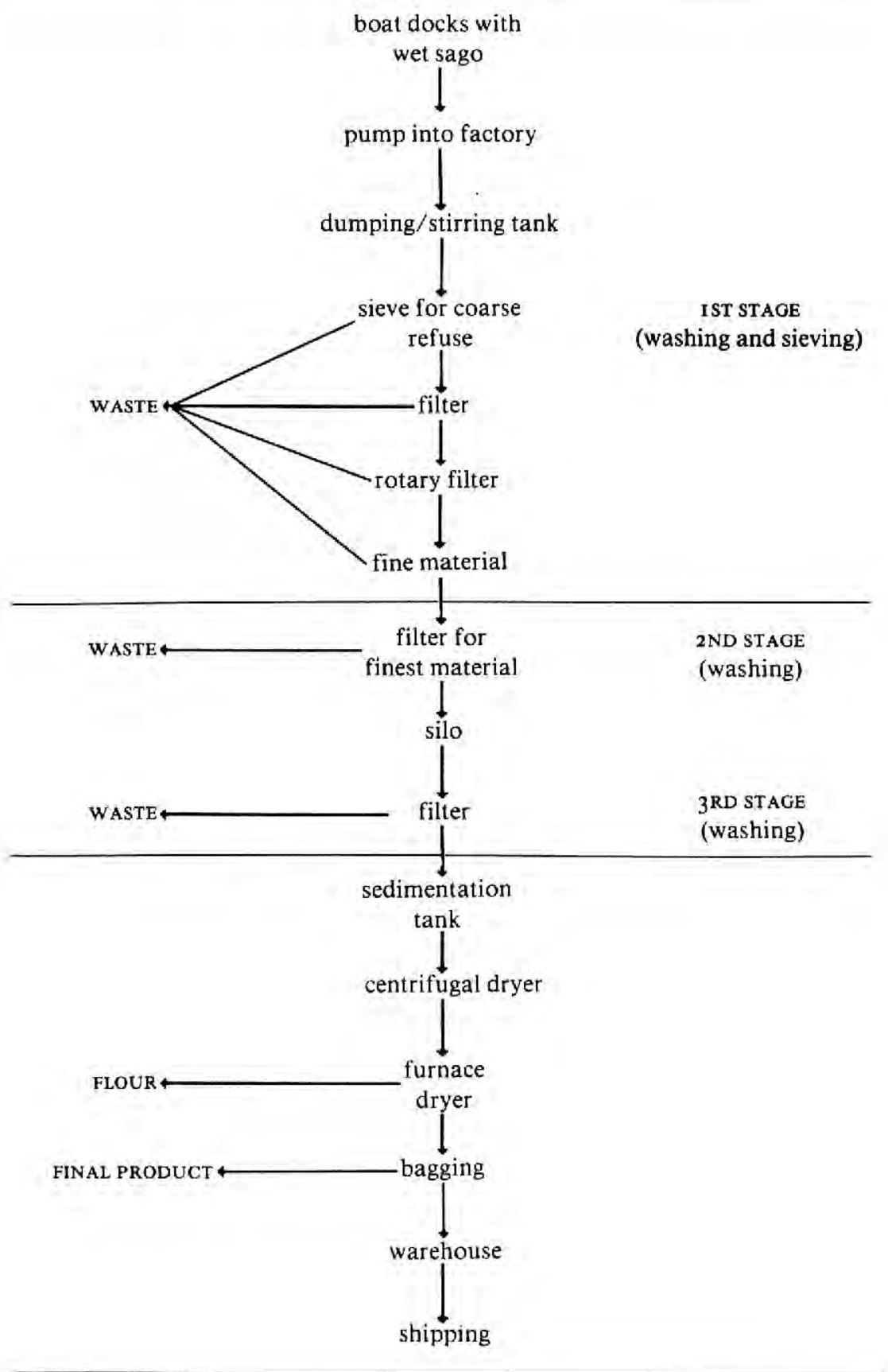


Sarawak Chemical Industries wholesales its products directly to customers known personally to the owner as a result of his having operated as a towkay for 30 years. During that period the owner bought sago from small producers and exported it without further processing. The company itself undertakes little market development, relying instead on solicitations of potential cutomers. Samples are sent in response to inquiries. The company generally makes three-month contracts with foreign importers. Sarawak Chemical Industries also exports, with further refining, flour produced by some of the smaller mills.

Sarawak Chemical Industries appears to face no competition from other potential producers of high grade sago starch within the near future. Neither need it fear a resurgence of Singaporean competition, given the difficulties experienced by that island's producers in securing raw materials. Similarly, the capacity of other sago-producing nations to manufacture high-grade palm stem starch is also far from realization: Indonesia's great potential is hampered by severe organizational difficulties; in Papua New Guinea sago production is limited to subsistence levels; and in peninsular Malaysia areas suitable for Metroxylon cultivation are too limited to sustain a large starch factory.

Among Southeast Asian products, Sarawak sago is presented with its strongest competition from Thai manioc starch. Formerly, Indonesian manioc starch was also competitive. Cornstarch, produced in Thailand too, also vies with sago in the starch market.

In the absence of any detailed studies of the relative advantages accruing to different Asian starches, it is useful to present the perceptions of Sarawak Chemical Industries in this context. Advantage, it is felt, depends basically on cost and quality of the product, knowledge of the market, and, lastly, on the peculiarities of a specific type of starch. With respect to market knowledge it is considered that Thai manioc starch manufacturers, with their well-established marketing sytem, definitely have an edge, whereas Sarawak sago producers are relative neophytes. This deficiency is widely acknowledged in Sarawak, and it is anticipated that the situation will soon be remedied.

More significant is the relative quality and cost of sago. Qualitatively, Thai manioc starch is regarded as superior to Sarawak sago starch. The first and second grades of each product are con- 
sidered to be of equal quality, but sago cannot yet compete with the so-called super grade of manioc starch. As the Sarawak process is developed, however, it is anticipated that this inequality will be eliminated.

Thai manioc starch is cheaper than Sarawak sago starch. An important factor in this price differential is the lower cost of unskilled labor in Thailand, which is only 15 to 20 percent of that in Sarawak. Manioc cultivation, however, demands greater labor inputs than sago, such that if sago cultivation techniques can be markedly upgraded this factor may, in the future, no longer be so significant.

If Sarawak is to progress beyond the stage of primary raw-material production, the development of sophisticated sago refineries, with a range of operational scales, must be fostered. These in turn could serve as focal points for the development of light manufacturing industries which use high grade starch as their chief raw material. Finally, a greater exploration of the requirements of the international starch market must be undertaken, and plans laid to ensure that sago starch can compete effectively with starch derived from other sources.

Potential new markets for sago products appear to exist. Recent experiments in Malaysia and Papua New Guinea, for example, indicate that sago, when combined with proteins, may become an important, cheap, locally-produced chicken and pig feed (Boon 1973; Dunsmore and Ong 1970; Jalaludin et al. 1970; Springhall and Ross 1965). The potential of sago waste for conversion to cattle feed through a fermented organic waste recycling process also bears examination. At the present time modern livestock operations in these areas depend largely on expensive, imported grains, particularly maize. The socioeconomic implications of various animal feeding trials are far-ranging: imports of feed grains could be substantially reduced, thus saving precious foreign exchange and, above all, a significant new outlet would be provided for sago products. 


\section{6 \\ INTERNATIONAL TRADE}

Statistical data on the international trade in sago palm products are generally incomplete, reflecting the relative commercial insignificance of these products, and the common local practice, within Southeast Asia, of using traditional means of transportation, which often pass unrecorded across international frontiers. Data sometimes do not discriminate sago from tapioca. The customs receipts of Thailand, for example, do not distinguish between "sago" and "sago made from tapioca," in the occasional small quantities imported (Kingdom of Thailand 1958); data for the People's Republic of China are similarly combined (table 11). From discussions with traders and from an examination of direction of trade data, we conclude, however, that the bulk of these shipments represents sago exports. Trade is mostly with Hong Kong, but small quantities are also shipped elsewhere in Southeast Asia. Sago is often only a relatively minor commodity in international trade, hence some countries (e.g., Hong Kong) record data on value only and others (e.g., Thailand [table 12]) do not distinguish between types of sago products. Data gaps and other problems also reveal flaws that characterize the statistical services of developing nations. The most useful data on the direction of trade in sago products are available for Singapore and Malaysia, but even these are confused as a result of postcolonial changes 
TABLE 11. People's Republic of China: Exports of Sago and Tapioca, 1964-1970 (metric tons)

\begin{tabular}{lrrrr}
\hline Importing Country & 1964 & 1966 & 1968 & 1970 \\
\hline Belgium and Luxembourg & - & - & - & 6 \\
Brunei & 4 & - & - & - \\
Eire & - & - & - & 6 \\
Hong Kong & 3,402 & 7,812 & 5,332 & 5,237 \\
Netherlands & - & - & - & 2 \\
Peninsular Malaysia & 1 & 9 & - & - \\
Sabah & 6 & 1 & 1.5 & - \\
Sarawak & 41 & 6 & - & - \\
Singapore & - & - & 5 & - \\
$\quad$ TOTAL & 3,454 & 7,829 & $5,338.5$ & 5,939 \\
\hline
\end{tabular}

SOURCE:

Institute of Developing Economies, Foreign Trade of China for 1964, 1966, 1968, 1970. Tokyo.

NOTE:

- Zero exports.

which make it virtually impossible, for example, to isolate exports of Singapore from those of West Malaysia during several years.

International commerce in sago palm products is confined to the Southeast Asian producing region, and between that area and other importing nations scattered throughout the world. Sago commerce is principally concentrated in the hands of Chinese merchants, and throughout Southeast Asia commodities flow among centers where Chinese have long been established. In Sarawak, for example, Chinese storekeepers in the rural bazaars do most of their business by selling sundry wares in return for local produce, including sago. The storekeeper dispatches suitable quantities of local products to a Chinese dealer who, in turn, combines the produce of several bazaars and sells them to big businessmen (towkays) in the ports (Broek n.d.:6-8). Formerly sago was shipped to Chinese-owned factories in Singapore for processing and then reexported to the world market. Chinese owners of small sago mills may sell to the towkays, whereas formerly they had the option of shipping their products directly to Singapore for further refining. Singapore merchants exploited a similar network in reverse for shipping the finished product back to some of the producing regions. Singapore's role has now declined. 
TABLE 12. Thailand: Exports of Sago Flour and Pearl Sago, 1955-1969

\begin{tabular}{|c|c|c|c|c|c|c|c|c|c|c|c|c|c|c|c|}
\hline 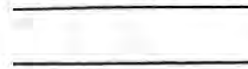 & 1955 & 1956 & 1957 & 1958 & 1959 & 1960 & 1961 & 1962 & 1963 & 1964 & 1965 & 1966 & 1967 & 1968 & 1969 \\
\hline Bahrein & - & - & 22 & 25 & - & - & - & - & - & - & - & - & - & - & - \\
\hline Belgium & - & - & - & - & 20 & - & - & - & - & - & - & - & - & - & - \\
\hline Cambodia & 32 & 6 & 26 & 1 & 81 & - & 103 & - & - & - & - & - & - & - & - \\
\hline Germany & - & - & - & - & - & - & - & - & - & - & - & - & 80 & - & - \\
\hline Italy & - & - & - & - & - & - & - & - & - & - & - & - & 5 & - & - \\
\hline Hong Kong & 275 & 197 & 141 & 138 & 118 & 1.77 & 205 & 187 & 144 & 123 & 139 & 125 & 125 & 102 & 102 \\
\hline Laos & 13 & 8 & 7 & 6 & 4 & 3 & 6 & 5 & - & - & - & - & - & 6 & - \\
\hline Lebanon & - & - & - & - & - & - & - & - & 2 & - & - & - & - & - & - \\
\hline Malaysia & 458 & 221 & 31 & 21 & 32 & - & - & 25 & - & - & 15 & 17 & 25 & 25 & 31 \\
\hline Netherlands & - & - & - & - & 123 & 69 & - & - & - & - & - & - & - & - & - \\
\hline Pakistan & - & - & - & - & - & - & - & - & - & - & $\bar{c}$ & - & 38 & - & $\overline{-}$ \\
\hline Sabah & 1 & 4 & 4 & 10 & 13 & 18 & 21 & 2 & 20 & 24 & 15 & 15 & 12 & 6 & 7 \\
\hline Saudi Arabia & - & - & - & - & - & - & - & 40 & 28 & - & - & - & - & - & - \\
\hline Singapore & 771 & 750 & 160 & 126 & 166 & 62 & 6 & 13 & 15 & 5 & - & - & - & - & - \\
\hline South Africa & - & - & - & - & - & - & - & - & 10 & - & - & - & - & - & - \\
\hline Taiwan & - & - & - & - & - & - & - & - & 5 & - & - & - & - & - & - \\
\hline \multicolumn{16}{|l|}{ United Arab } \\
\hline Emirates & - & 31 & - & - & - & - & - & - & - & - & - & - & - & - & - \\
\hline United Kingdom & - & 10 & - & - & - & - & - & - & - & - & - & - & - & $\overline{0}$ & - \\
\hline U.S.A. & 45 & 320 & 53 & 53 & 61 & 34 & 30 & 1 & 103 & 10 & 12 & 5 & 10 & 8 & 10 \\
\hline TOTAL & 1,595 & 1,547 & 444 & 383 & 618 & 363 & 371 & 273 & 327 & 162 & 181 & 162 & 295 & 147 & 150 \\
\hline
\end{tabular}

SOURCE:

Kingdom of Thailand $\mathrm{n} . \mathrm{d}$.

NoTES:

In M.T., converted from $\mathrm{kg}$ and rounded; - zero exports. 
An examination of Singapore's fluctuating fortunes in the international sago trade illustrates the range of external factors which have, at various times, impinged upon the industry. ${ }^{1}$ In addition to the Great Depression, and World War II, the recent international trade in sago has suffered from such adverse factors as: poor prices, which often caused primary producers in Sarawak and Indonesia to switch to other crops, principally rubber (1927: $40 ; 1938: 28)$; competition from other starches $(1954: 20,27)$; limitation of imports, particularly by a heavy Japanese duty proposed in 1932 (1932:19) and by India's withdrawal of import permits in 1952 (1953:26); the boycott of sales to Japan during the SinoJapanese war (1938:28); primary producers shipping direct to consumers (1952:27); high freight rates applied to a low-value commodity, particularly after the Suez crisis (1956:24); difficulty of securing raw materials, especially after the Korean war stimulated over-cutting in Sarawak (1953:25); and as a result of rebellion in Indonesian producing regions (1958:27).

Despite a postwar recovery in the United Kingdom market, it was becoming evident by the early 1950s that the fate of sago starch was closely linked with the vicissitudes of the Lancashire textile industry. In 1951 the Singapore Chamber of Commerce forecast a "lean outlook" for sago starch on the British scene (1951:28). Three years later, with the Lancashire cotton industries prostrate from foreign, largely Japanese, competition, the British industrial demand for sago continued to plummet (1954:24).

Damaging though such factors were to Singapore's sago industry, none was fatal. Singapore, playing an intermediary role in the business, always depended on a continuous flow of raw material from the nearby provinces of Indonesia. Sarawak was too distant for the small wooden ships hauling sago, and West Malaysia was only an insignificant supplier. Thus when supplies of raw material from Indonesia became scarce toward the end of 1957, owing to severely depressed prices, Singapore factories were unable to stockpile and could only produce pearl sago against orders (1958:27). Supply problems also arose because of insurrection in Indonesia.

More decisive in the long term, however, were governmental problems which were first noted in 1955 (p. 26), when the Indonesian customs officials restricted the flow of Siak sago flour to Sin- 
TABLE 13. Indonesia: Exports of Sago, 18791974

\begin{tabular}{|c|c|c|c|}
\hline Year & Refined & Raw & Pearl \\
\hline $1879^{a}$ & & $1,630.0$ & \\
\hline $1880^{a}$ & & $2,100.3$ & \\
\hline $1881^{\mathrm{a}}$ & & $3,878.1$ & \\
\hline $1882^{a}$ & & $3,100.7$ & \\
\hline $1883^{a}$ & & $4,765.6$ & \\
\hline $1884^{a}$ & & $5,202.2$ & \\
\hline $1885^{a}$ & & $5,733.8$ & \\
\hline $1886^{a}$ & & $6,051.8$ & \\
\hline $1887^{a}$ & & $8,019.9$ & \\
\hline $1888^{a}$ & & $8,834.6$ & \\
\hline $1889^{a}$ & & $10,009.3$ & \\
\hline $1890^{a}$ & & $9,036.3$ & \\
\hline $1891^{a}$ & & $8,566,2$ & \\
\hline $1892^{\mathrm{a}}$ & & $7,337.7$ & \\
\hline $1893^{a}$ & & $4,713.3$ & \\
\hline $1894^{a}$ & & $3,753.5$ & \\
\hline 1895 a & & $4,010.8$ & \\
\hline $1896^{a}$ & & $6,084.7$ & \\
\hline $1897^{a}$ & & $3,984.7$ & \\
\hline $1898^{a}$ & & $7,306.7$ & \\
\hline $1899 a$ & & $11,696.0$ & \\
\hline $1900^{a}$ & & $12,054.8$ & \\
\hline $1901^{\mathrm{a}}$ & $2,469.3$ & $9,963.6$ & - \\
\hline $1902^{a}$ & $4,016.0$ & $12,407.2$ & - \\
\hline $1903^{a}$ & $4,696.1$ & $16,179.0$ & - \\
\hline $1904^{\mathrm{a}}$ & $4,581.4$ & $15,334.0$ & - \\
\hline $1905^{a}$ & $1,382.9$ & $15,887.5$ & - \\
\hline $1906^{a}$ & $4,085.3$ & $11,685.7$ & - \\
\hline $1907^{a}$ & $2,407.6$ & $14,391.3$ & - \\
\hline $1908^{a}$ & $4,906.2$ & $12,015.8$ & - \\
\hline $1909 a$ & $7,947.5$ & $6,064,6$ & - \\
\hline $1910^{a}$ & $5,729.8$ & $8,079.3$ & - \\
\hline $1911^{a}$ & $3,376.1$ & $7,859.5$ & - \\
\hline $1912^{a}$ & $4,794.3$ & $8,223.2$ & - \\
\hline $1913^{a}$ & $4,772.4$ & $9,204.9$ & - \\
\hline $1914^{a}$ & $5,054.0$ & $26,483,7$ & - \\
\hline $1915^{a}$ & $7,489.7$ & $9,035.1$ & 11.7 \\
\hline $1916^{a}$ & $9,307.1$ & $10,140.7$ & - \\
\hline $1917^{a}$ & $5,474.5$ & $8,132.2$ & 14.5 \\
\hline $1918^{\mathrm{a}}$ & $3,743.5$ & $7,416.0$ & - \\
\hline $1919^{a}$ & $11,063.8$ & $13,821.2$ & 54,4 \\
\hline $1920^{\mathrm{a}}$ & $10,503.1$ & $4,205.3$ & - \\
\hline $1921^{a}$ & $5,770.5$ & $3,570.8$ & 35.8 \\
\hline $1922^{a}$ & $10,389.7$ & $6,993.2$ & 30.1 \\
\hline $1923^{a}$ & $6,285.3$ & $6,253.8$ & 63.7 \\
\hline $1924-1927$ & $\ldots$ & $\ldots$ & $\ldots$ \\
\hline $1928^{\mathrm{b}}$ & $19,361.0$ & $4,587.0$ & - \\
\hline
\end{tabular}


TABLE 13. (cont.)

\begin{tabular}{|c|c|c|c|}
\hline Year & Refined & Raw & Pearl \\
\hline $1929 \mathrm{~b}$ & $22,617.0$ & $4,877,0$ & 35.0 \\
\hline $1930^{b}$ & $27,045.0$ & $9,002.0$ & 55.0 \\
\hline $1931^{b}$ & $26,233,0$ & $4,794.0$ & - \\
\hline $1932^{b}$ & $33,671.0$ & $6,001,0$ & 1.0 \\
\hline $1933^{b}$ & $31,827.0$ & $2,188,0$ & - \\
\hline $1934^{b}$ & $23,733.0$ & $7,307.0$ & - \\
\hline $1935^{\circ}$ & $32,807.0$ & $8,691.0$ & - \\
\hline $1936^{b}$ & $38,903.0$ & $8,593,0$ & 1.0 \\
\hline $1937^{\mathrm{b}}$ & $29,124.0$ & $8,592.0$ & 7.0 \\
\hline $1938^{b}$ & $22,459.0$ & $5,659.0$ & 3.0 \\
\hline 1939 & $\ldots$ & $\ldots$ & $\ldots$ \\
\hline $1940^{\mathrm{c}}$ & $30,555.5$ & $4,306.7$ & 38.9 \\
\hline 1941-1951 & $\ldots$ & $\ldots$ & $\ldots$ \\
\hline $1952^{d}$ & $23,872.7$ & $12,393.0$ & - \\
\hline $1953^{d}$ & $28,716.7$ & $16,659.1$ & - \\
\hline $1954^{d}$ & $25,248.8$ & $8,391.9$ & - \\
\hline $1955^{d}$ & $19,128.2$ & $4,475.5$ & - \\
\hline $1956^{d}$ & $19,201.8$ & $3,856.2$ & 7.6 \\
\hline $1957 \mathrm{c}$ & $13,902.7$ & $3,629.4$ & - \\
\hline $1958^{c}$ & $14,676.2$ & $1,852.9$ & - \\
\hline $1959^{e}$ & $14,762.8$ & $2,795.1$ & - \\
\hline $1960^{\mathrm{e}}$ & $10,171.0$ & $2,439.0$ & - \\
\hline $1961^{e}$ & $15,040.4$ & $2,157.8$ & - \\
\hline $1962^{e}$ & $14,929.3$ & $3,453.5$ & 8.1 \\
\hline $1963^{\mathrm{e}}$ & $10,860.0$ & $3,734.0$ & - \\
\hline $1964^{\mathrm{e}}$ & - & 425.0 & - \\
\hline $1965^{e}$ & - & $3,755.0$ & - \\
\hline $1966^{e}$ & - & $2,074.0$ & - \\
\hline $1967 \mathrm{e}$ & 70.7 & $11,712.0$ & - \\
\hline $1968^{\mathrm{e}}$ & 496.3 & $10,488.6$ & - \\
\hline $1969^{\mathrm{e}}$ & 30.4 & $7,063.0$ & - \\
\hline $1970^{e}$ & 134.5 & $4,461.5$ & - \\
\hline $1971^{e}$ & - & $2,635.2$ & - \\
\hline $1972^{c}$ & - & 35.3 & - \\
\hline $1973^{c}$ & $\ldots$ & $\ldots$ & $\ldots$ \\
\hline $1974^{e}$ & 115.0 & 2.0 & - \\
\hline
\end{tabular}

SOURCES:

a Netherlands East Indies, Dienst der In-en Uityoerrechten en Accijnzen, various years.

b Cohen 1939.

c Netherlands East Indies, Centraal Kantoor voor de Statistiek, various years.

d Republic of Indonesia n.d.b. Biro Pusat Statistik, Penerbitan bulanan, Statistik perdagangan: Ekspor (title varies slightly).

e Republic of Indonesia n.d.a. NoTes:

In M.T., converted from $\mathrm{kg}$ and rounded; - zero exports; . . . no data available. 
gapore. At that time the problem was solved by importing sago pith instead of flour. In 1960 a misunderstanding between Singaporean importers and Indonesian customs officers arose in Sumatra, the repercussions of which underlined the vulnerability of the sago industry in Singapore, when the supply of Indonesian raw material declined by some 30 percent in the last quarter of the year (1960:39).

The fatal blow came three years later, when in September 1963, because of the Indonesian policy of Konfrontasi, no further supplies of Indonesian sago were received for processing in Singapore (1963:65). Shortly thereafter flour refineries and pearl sago manufacturing plants closed. Now Singapore's role in the international sago trade is limited to that of serving as a transshipment and warehousing point, and a trade headquarters (Ang pers. comm.). Thus, until recently, Singapore was the hub of both the regional and international sago trade, being the center for processing sago raw materials from within the region, a reexporter of finished products back to the producing regions, and an exporter of sago to many other countries.

Historically, Indonesia has been a major exporter of sago products (table 13). Confrontation with Malaysia led to a considerable redirection of Indonesia's export trade in raw materials. From the time direction of trade data for sago first became available (table 14), until the early 1960s, the bulk of Indonesia's exports of all sago products were sent to Singapore, but during 1964-65 this flow was interrupted. Elsewhere in Asia, West Malaysia has, historically, been a fairly regular importer of small quantities of Indonesian sago. Small amounts were intermittently shipped to the People's Republic of China, Hong Kong, Japan, the Philippines, Sabah, Sarawak, and Thailand.

During the period of confrontation with Malaysia and Singapore, Hong Kong became the major importer of Indonesian sago. In the rest of the world the Netherlands has been the most regular small-scale importer. Small quantities have occasionally been shipped to other European nations. The United States has occasionally taken imports, as has Australia. Prior to World War I, Christmas Island and the Cocos Islands were fairly regular importers of less than 1 MT per annum.

Indonesia is also a minor importer of sago products (table 15). 
TABLE 14. Indonesia: Direction of All Sago Exports, 1879-1974

\begin{tabular}{|c|c|c|c|c|c|c|c|c|c|}
\hline \multirow[b]{2}{*}{ Year } & \multicolumn{9}{|c|}{ Importing Country } \\
\hline & $\begin{array}{l}\text { Singa- } \\
\text { pore }\end{array}$ & $\begin{array}{l}\text { Hong } \\
\text { Kong }\end{array}$ & $\begin{array}{l}\text { West } \\
\text { Malaysia }\end{array}$ & $\begin{array}{l}\text { Other } \\
\text { Asia }\end{array}$ & $\begin{array}{l}\text { Nether- } \\
\text { lands }\end{array}$ & $\begin{array}{l}\text { United } \\
\text { Kingdom }\end{array}$ & $\begin{array}{l}\text { Other } \\
\text { Europe }\end{array}$ & USA & Oceania \\
\hline $1879^{a}$ & $1,626.7$ & - & - & 3.3 & - & - & - & - & - \\
\hline $1880^{\mathrm{a}}$ & $2,099,9$ & - & - & - & - & - & - & - & 0.4 \\
\hline $1881^{a}$ & $3,851.8$ & - & - & - & - & - & - & - & 26.3 \\
\hline $1882^{\text {a }}$ & $3,099.9$ & - & - & - & - & - & - & - & 0.8 \\
\hline $1883^{8}$ & $4,736.7$ & - & 12.0 & 16.8 & - & - & - & - & - \\
\hline $1884^{a}$ & $5,188.3$ & - & 3.0 & 9.0 & 1.9 & - & - & - & - \\
\hline $1885^{a}$ & $5,727.5$ & - & - & - & - & 6.0 & - & - & 0.4 \\
\hline $1886^{\mathrm{a}}$ & $6,014.8$ & - & 24.2 & 12.3 & - & - & - & - & 0.5 \\
\hline $1887^{a}$ & $7,915.9$ & - & 62.5 & - & 41.1 & - & - & - & 0.5 \\
\hline $1888^{a}$ & $8,767.8$ & 11.5 & 55.3 & - & - & - & - & - & - \\
\hline $1889^{a}$ & $9,949.6$ & - & 29.9 & 29.7 & - & - & - & - & - \\
\hline $1890^{\mathrm{a}}$ & $9,013.8$ & - & 22.5 & - & - & - & - & - & - \\
\hline $1891^{a}$ & $8,541.1$ & 1.8 & 2,4 & - & - & 20.9 & - & - & - \\
\hline $1892^{a}$ & $7,337,7$ & - & - & - & 1.9 & 14.0 & - & - & - \\
\hline $1893^{a}$ & $4,713.3$ & - & - & - & - & - & - & - & - \\
\hline $1894^{\mathrm{a}}$ & $3,753.5$ & - & - & - & - & - & - & - & - \\
\hline $1895^{a}$ & $4,010.8$ & - & - & - & - & - & - & - & - \\
\hline $1896^{a}$ & $6,084.7$ & - & - & - & - & - & - & - & - \\
\hline $1897^{a}$ & $3,984.7$ & - & - & - & - & - & - & - & - \\
\hline $1898^{a}$ & $7,300.5$ & - & - & - & 6.2 & - & - & - & - \\
\hline $1899^{a}$ & $11,696.0$ & - & - & - & - & - & - & - & - \\
\hline $1900^{a}$ & $12,051.3$ & - & 0.1 & 3.2 & 0.3 & - & - & - & - \\
\hline $1901^{a}$ & $2,467.5$ & - & - & - & 2.2 & - & - & - & - \\
\hline $1902^{\mathrm{a}}$ & $12,407.2$ & 87.0 & - & - & - & - & - & - & - \\
\hline
\end{tabular}


TABLE 14. (cont.)

\begin{tabular}{|c|c|c|c|c|c|c|c|c|c|}
\hline \multirow[b]{2}{*}{ Year } & \multicolumn{9}{|c|}{ Importing Country } \\
\hline & $\begin{array}{l}\text { Singa- } \\
\text { pore }\end{array}$ & $\begin{array}{l}\text { Hong } \\
\text { Kong }\end{array}$ & $\begin{array}{l}\text { West } \\
\text { Malaysia }\end{array}$ & $\begin{array}{l}\text { Other } \\
\text { Asia }\end{array}$ & $\begin{array}{l}\text { Nether- } \\
\text { lands }\end{array}$ & $\begin{array}{l}\text { United } \\
\text { Kingdom }\end{array}$ & $\begin{array}{l}\text { Other } \\
\text { Europe }\end{array}$ & USA & Oceania \\
\hline $1903^{a}$ & $20,874.3$ & - & 0.8 & - & - & - & - & - & - \\
\hline $1904^{a}$ & $19,894.2$ & - & 2.0 & 9.4 & 10.0 & - & - & - & - \\
\hline $1905^{a}$ & $17,266.0$ & - & 4.4 & - & - & - & - & - & - \\
\hline $1906^{a}$ & $15,746.4$ & - & 3.4 & - & 4.9 & 4.6 & - & - & 8.7 \\
\hline $1907^{a}$ & $16,744.4$ & - & - & - & 2.6 & 19.9 & - & - & 21.8 \\
\hline $1908^{a}$ & $16,916.2$ & - & 3.9 & 0.5 & - & - & - & - & 0.6 \\
\hline $1909^{\mathrm{a}}$ & $13,807.2$ & 0.2 & - & - & 37.8 & - & 149.7 & - & - \\
\hline $1910^{a}$ & $14,033.2$ & - & 0.8 & - & 322.6 & 70.0 & 180.8 & - & 0.2 \\
\hline $1911^{\mathrm{a}}$ & $13,840.0$ & - & 16.9 & 3.1 & 547.9 & 507.2 & 13.7 & 123.3 & - \\
\hline $1912^{a}$ & $21,512.3$ & - & 36.4 & 1.5 & 561.0 & 209.3 & 495.1 & - & - \\
\hline $1913^{a}$ & $12,979.4$ & - & 9.1 & 1.2 & 560.0 & 393.0 & 1.8 & - & 0.1 \\
\hline $1914^{\mathrm{a}}$ & $30,919.6$ & 1.6 & 8.7 & 10.8 & 80.7 & 520.8 & - & - & - \\
\hline $1915^{\mathrm{a}}$ & $17,674.5$ & - & - & - & - & 99.0 & - & 51.0 & - \\
\hline $1916^{\mathrm{a}}$ & $18,408.2$ & - & 9.4 & 6.8 & 78.5 & 402.6 & - & 428.6 & - \\
\hline $1917^{a}$ & $13,119.7$ & - & 10.1 & 67.1 & - & 271.0 & - & - & - \\
\hline $1918^{a}$ & $10,587.3$ & - & 2.1 & 108.4 & - & - & - & - & - \\
\hline $1919^{a}$ & $24,848.8$ & 0.2 & - & 54.3 & 101.3 & - & - & - & - \\
\hline $1920^{\mathrm{a}}$ & $14,382.1$ & - & 0.1 & 158.5 & 27.1 & - & - & 38.6 & - \\
\hline $1921^{\mathrm{a}}$ & $9,168.3$ & - & - & 174.18 & 1.2 & 29.4 & - & - & - \\
\hline $1922^{a}$ & $17,503.1$ & - & 10.5 & - & - & 3.8 & - & - & - \\
\hline $1923^{\mathrm{a}}$ & $12,524.1$ & 3.8 & - & - & - & - & - & - & - \\
\hline $1924-1939$ & $\ldots$ & $\ldots$ & $\ldots$ & $\ldots$ & $\ldots$ & $\ldots$ & $\ldots$ & $\cdots$ & $\ldots$ \\
\hline $1940^{\mathrm{b}}$ & $34,885.1$ & - & - & - & - & - & - & - & - \\
\hline
\end{tabular}




\begin{tabular}{|c|c|c|c|c|c|c|c|c|c|}
\hline $1941-1951$ & - & - & - & - & - & - & - & - & - \\
\hline $1952^{c}$ & $36,265.7$ & - & - & - & - & - & - & - & - \\
\hline $1953^{c}$ & $44,975,8$ & - & - & - & - & - & - & - & - \\
\hline $1954^{\mathrm{c}}$ & $33,640.7$ & - & - & - & - & - & - & - & - \\
\hline $1955^{c}$ & $23,603.2$ & - & - & - & - & - & - & - & - \\
\hline $1956^{c}$ & $23,058.1$ & - & - & - & - & - & - & - & - \\
\hline $1957^{d}$ & $17,532.1$ & - & - & - & - & - & - & - & - \\
\hline $1958^{d}$ & $16,529.1$ & - & - & - & - & - & - & - & - \\
\hline $1959^{d}$ & $17,557.9$ & - & - & - & - & - & - & - & - \\
\hline $1960^{d}$ & $18,015,4$ & - & - & - & - & - & - & - & - \\
\hline $1961^{d}$ & $17,198.2$ & - & - & - & - & - & - & - & - \\
\hline $1962^{d}$ & $18,382.8$ & - & - & - & - & - & - & - & - \\
\hline $1963^{d}$ & $14,594.0$ & - & - & - & - & - & - & - & - \\
\hline $1964^{d}$ & - & 425.0 & - & - & - & - & - & - & - \\
\hline $1965^{d}$ & - & $3,755.0$ & - & - & - & - & - & - & - \\
\hline $1966^{d}$ & 41.0 & $2,033.0$ & - & - & - & - & - & - & - \\
\hline $1967^{d}$ & $11,678.8$ & 103.9 & - & - & - & - & - & - & - \\
\hline $1968^{d}$ & $10,982,8$ & - & 2.1 & - & - & - & - & - & - \\
\hline $1969^{d}$ & $7,092.7$ & - & 31.0 & - & - & - & - & - & - \\
\hline $1970^{d}$ & $4,596.0$ & - & - & - & - & - & - & - & - \\
\hline $1971^{d}$ & $2,634.1$ & - & - & - & 0.6 & - & 0.6 & - & - \\
\hline $1972^{d}$ & 34.7 & - & - & - & 6.7 & - & - & - & - \\
\hline $1973^{d}$ & - & - & - & - & - & - & - & - & - \\
\hline $1974^{d}$ & - & 100.0 & - & - & 100,0 & - & - & - & - \\
\hline
\end{tabular}

SOURCES:

a Netherlands East Indies, Dienst der In- en Uitvoerrechten en Accijnzen.

b Netherlands East Indies, Centraal Kantoor voor de Statistiek.

Notes:

C Republic of Indonesia n.d.b. available.

d Republic of Indonesia n.d.a. 
TABLE 15. Indonesia: Direction of Import Trade of Sago, 1879-1940

\begin{tabular}{|c|c|c|c|c|c|c|c|c|c|c|}
\hline \multirow[b]{2}{*}{ Year } & \multicolumn{10}{|c|}{ Country of Origin } \\
\hline & China & $\begin{array}{l}\text { Hong } \\
\text { Kong }\end{array}$ & Japan & $\begin{array}{l}\text { Nether- } \\
\text { lands }\end{array}$ & Sabah & Sarawak & $\begin{array}{l}\text { Singa- } \\
\text { pore }\end{array}$ & $\begin{array}{l}\text { United } \\
\text { Kingdom }\end{array}$ & $\begin{array}{l}\text { West } \\
\text { Malaysia }\end{array}$ & Total \\
\hline 1879 & - & - & - & - & - & - & 26.9 & - & 1.9 & 28.7 \\
\hline 1880 & - & - & - & - & - & - & 130.7 & - & 0.6 & 131.3 \\
\hline 1881 & 1.0 & - & - & - & - & - & 64.1 & - & 1.2 & 66.3 \\
\hline 1882 & - & - & - & - & - & - & 129.1 & - & 0.1 & 129.2 \\
\hline 1883 & 6.8 & 0.3 & - & - & - & - & 15.7 & - & - & 22.7 \\
\hline 1884 & - & - & - & - & - & 0.4 & 28.9 & - & 0.1 & 29.5 \\
\hline 1885 & - & - & - & - & - & - & 201.2 & - & 0.2 & 201.4 \\
\hline 1886 & 1.1 & - & - & - & - & 0.9 & 37.8 & - & 1.8 & 41.6 \\
\hline 1887 & 1.3 & - & - & - & - & - & 33.1 & - & - & 34.4 \\
\hline 1888 & - & - & - & - & - & - & 13.2 & - & 0.7 & 13.9 \\
\hline 1889 & - & 0.2 & - & - & - & - & 32.3 & - & 2.6 & 35.2 \\
\hline 1890 & 0.4 & - & - & - & - & - & 33.8 & - & 2.0 & 36.2 \\
\hline 1891 & - & - & - & - & - & - & 58.7 & - & 8.7 & 67.4 \\
\hline 1892 & - & - & - & - & - & - & 40.3 & _ & 9.2 & 49.5 \\
\hline 1893 & - & - & - & - & - & - & 32.4 & - & 8.0 & 40.4 \\
\hline 1894 & - & - & - & - & - & - & 53.0 & - & 12.8 & 65.7 \\
\hline 1895 & - & - & - & - & - & - & 69.7 & 0.1 & 17.0 & 86.8 \\
\hline 1896 & - & - & - & - & - & - & 67.6 & - & 16.3 & 83.9 \\
\hline 1897 & - & - & - & - & - & - & 113.0 & 1.0 & 26.8 & 139.8 \\
\hline 1898 & - & - & - & 12.5 & - & - & 89.3 & - & 27.3 & 129.1 \\
\hline 1899 & - & - & - & - & - & - & 71.2 & - & 39.8 & 111.0 \\
\hline 1900 & - & - & - & - & - & - & 102.4 & - & 78.8 & 181.2 \\
\hline
\end{tabular}




\begin{tabular}{|c|c|c|c|c|c|c|c|c|c|c|}
\hline 1901 & - & - & - & - & - & - & 97.7 & - & 50.5 & 148.3 \\
\hline 1902 & - & - & - & 0.1 & - & - & 132.5 & - & 90.7 & 223.2 \\
\hline 1903 & 2.7 & - & - & - & - & 1.0 & 128.0 & - & 93.5 & 225.2 \\
\hline 1904 & - & 0.2 & - & - & - & - & 106.2 & - & 69.7 & 176.1 \\
\hline 1905 & - & - & - & - & - & - & 80.2 & - & 73.8 & 153.9 \\
\hline 1906 & - & 0.5 & - & - & - & - & 65.9 & - & 55.4 & 121.8 \\
\hline 1907 & - & 0.1 & - & - & - & - & 49.0 & - & 39.3 & 88.3 \\
\hline 1908 & - & - & - & - & - & - & 23.5 & - & 29.0 & 52.5 \\
\hline 1909 & - & 15.9 & - & - & - & 0.2 & 31.9 & - & 28.3 & 76.3 \\
\hline 1910 & 22.8 & 1.1 & - & - & - & - & 41.7 & 3.9 & 42.8 & 112.2 \\
\hline 1911 & 32.4 & 2.8 & - & 1.1 & - & - & 87.3 & - & 35.6 & 159.3 \\
\hline 1912 & 9.8 & 2.1 & - & - & - & - & 36.9 & 10.3 & 39.3 & 98.5 \\
\hline 1913 & 27.0 & 0.9 & - & - & - & - & 61.8 & 22.2 & 46.3 & 158.1 \\
\hline 1914 & 20.3 & - & - & - & - & - & 63.64 & - & 81.0 & 165.0 \\
\hline 1915 & 13.4 & - & - & - & - & - & 85.1 & - & 64.7 & 163.2 \\
\hline 1916 & 11.4 & - & - & - & - & - & 66.7 & - & 72.8 & 150.9 \\
\hline 1917 & 9.1 & 0.5 & - & - & - & - & 91.8 & - & 58.6 & 160.0 \\
\hline 1918 & - & 0.3 & 8.8 & - & - & - & 85.5 & - & 82.0 & 176.5 \\
\hline 1919 & - & - & - & - & - & - & 110.9 & - & 122.0 & 232.8 \\
\hline 1920 & - & 0.1 & - & - & - & - & 104.6 & - & 115.2 & 219.9 \\
\hline 1921 & - & - & - & - & - & - & 69.2 & - & 78.7 & 148.0 \\
\hline 1922 & - & - & - & - & - & - & 9.4 & - & - & 9.4 \\
\hline 1923 & - & - & - & - & - & - & 60.0 & - & 51.1 & 111.0 \\
\hline $1924-1940$ & $\ldots$ & $\ldots$ & $\ldots$ & $\ldots$ & $\ldots$ & $\ldots$ & $\ldots$ & $\ldots$ & $\ldots$ & $\ldots$ \\
\hline
\end{tabular}

SOURCE:

Netherlands East Indies n.d.b.

Notes:

Figures in M.T., converted from kg and rounded; - zero exports; . . . no data available. 
TABLE 16. Direction of Import Trade in Sago Flour and Meal, 1960-1974"

\begin{tabular}{|c|c|c|c|c|c|c|c|c|c|c|c|c|c|c|c|}
\hline \multicolumn{16}{|l|}{ Country of } \\
\hline Origin & 1960 & 1961 & 1962 & 1963 & 1964 & 1965 & 1966 & 1967 & 1968 & 1969 & 1970 & 1971 & 1972 & 1973 & $1974^{\circ}$ \\
\hline & \multicolumn{15}{|c|}{ To Brunei } \\
\hline Australia & $\ldots$ & $\ldots$ & $\ldots$ & 0.1 & - & - & - & - & - & - & - & - & - & - & - \\
\hline China $^{c}$ & $\ldots$ & $\ldots$ & $\ldots$ & 0.1 & - & 0.2 & - & 0.3 & - & - & - & - & 0.7 & 0.1 & - \\
\hline Hong Kong & $\ldots$ & $\ldots$ & $\ldots$ & 0.4 & 1.0 & 1.1 & - & 0.9 & - & - & - & 0.1 & - & - & - \\
\hline India $^{d}$ & $\ldots$ & $\ldots$ & $\ldots$ & - & - & - & - & - & - & - & - & - & - & - & - \\
\hline Sabah & $\ldots$ & $\ldots$ & $\ldots$ & - & - & - & - & - & 0.2 & - & - & - & - & - & - \\
\hline Sarawak & $\ldots$ & $-e$ & $-c$ & - & - & $1.5^{\mathrm{c}}$ & 0.6 & - & 2.0 & 2.1 & 1.0 & 1.5 & 2.3 & 2.5 & 1.1 \\
\hline Singapore & $0.9^{e}$ & $1.7^{r}$ & $0.7^{f}$ & $0.3^{r}$ & $1.0^{\prime}$ & 0.2 & 0.3 & 1.1 & 4.7 & 5,8 & 8.4 & 5.4 & 3.2 & 6,8 & 4.6 \\
\hline Thailand & $\ldots$ & $-\ldots$ & $\ldots$ & 0.2 & - & - & 0.1 & 0.2 & 1.0 & 0.1 & 3.1 & 2.1 & 0.2 & - & - \\
\hline West Malaysia & $\ldots$ & $\ldots$ & $\ldots$ & - & - & - & 0.2 & 0.1 & - & - & - & - & 0.2 & 0.2 & - \\
\hline \multirow[t]{2}{*}{ Total } & $\cdots$ & $\ldots$ & $\ldots$ & 1.1 & 2.0 & 3.0 & 1.2 & 2.6 & 7.9 & 7.9 & 12.5 & 9.1 & 6.6 & 9.6 & 5.7 \\
\hline & \multicolumn{15}{|c|}{ To Sabah } \\
\hline China $^{c}$ & $\ldots$ & $\ldots$ & $\ldots$ & $\ldots$ & - & - & - & - & - & - & - & 0.1 & - & - & $\ldots$ \\
\hline Hong Kong & $\ldots$ & $\ldots$ & $\ldots$ & $\ldots$ & 0.1 & 0.8 & 0.8 & 0.2 & 0.4 & - & - & - & - & - & $\ldots$ \\
\hline India & $\ldots$ & $\ldots$ & $\ldots$ & $\ldots$ & - & - & - & - & - & - & - & - & - & - & $\ldots$ \\
\hline Japan & $\ldots$ & $\cdots$ & $\ldots$ & $\ldots$ & - & - & - & - & - & - & - & - & - & 7 & $\cdots$ \\
\hline Netherlands & $\ldots$ & $\ldots$ & $\ldots$ & $\ldots$ & - & 0.4 & - & - & - & - & - & - & - & $\bar{s}$ & $\cdots$ \\
\hline Sarawak & $\ldots$ & $\ldots$ & $\ldots$ & $\ldots$ & - & - & - & - & 5.5 & 5.5 & - & - & - & 12.5 & $\ldots$ \\
\hline Singapore & $\ldots$ & $\ldots$ & $\ldots$ & $\ldots$ & 0.1 & 0.1 & - & 0.1 & 0.1 & - & - & 0.1 & - & 0.1 & $\ldots$ \\
\hline Thailand & $\ldots$ & $\ldots$ & $\ldots$ & $\ldots$ & 2.4 & 0.9 & 1.6 & 1.4 & 0.2 & 0.6 & - & - & 0.1 & 0.4 & $\ldots$ \\
\hline Vietnam & $\cdots$ & $\ldots$ & $\ldots$ & $\ldots$ & 0.2 & - & - & - & - & - & - & - & - & - & $\ldots$ \\
\hline West Malaysia & $\ldots$ & $\ldots$ & $\ldots$ & $\ldots$ & - & 0.7 & - & - & - & 0.1 & - & - & - & - & $\cdots$ \\
\hline \multirow[t]{2}{*}{ Total } & $\cdots$ & $\cdots$ & $\cdots$ & $\ldots$ & 2.8 & 2.9 & 2.4 & 1.7 & 6.2 & 6.2 & - & 0.2 & 0.1 & 13.0 & $\ldots$ \\
\hline & \multicolumn{15}{|c|}{ To Sarawak } \\
\hline Brunei & $\ldots$ & $\ldots$ & - & 1.1 & 0.5 & 0.6 & 1.08 & 1.6 & - & - & - & - & - & - & $\ldots$ \\
\hline China $^{c}$ & $\ldots$ & $\ldots$ & - & - & 0.7 & - & - & - & - & - & - & - & - & - & $\ldots$ \\
\hline Hong Kong & $\ldots$ & $\ldots$ & - & 1.8 & 0.1 & - & - & - & - & - & - & - & - & - & $\cdots$ \\
\hline
\end{tabular}




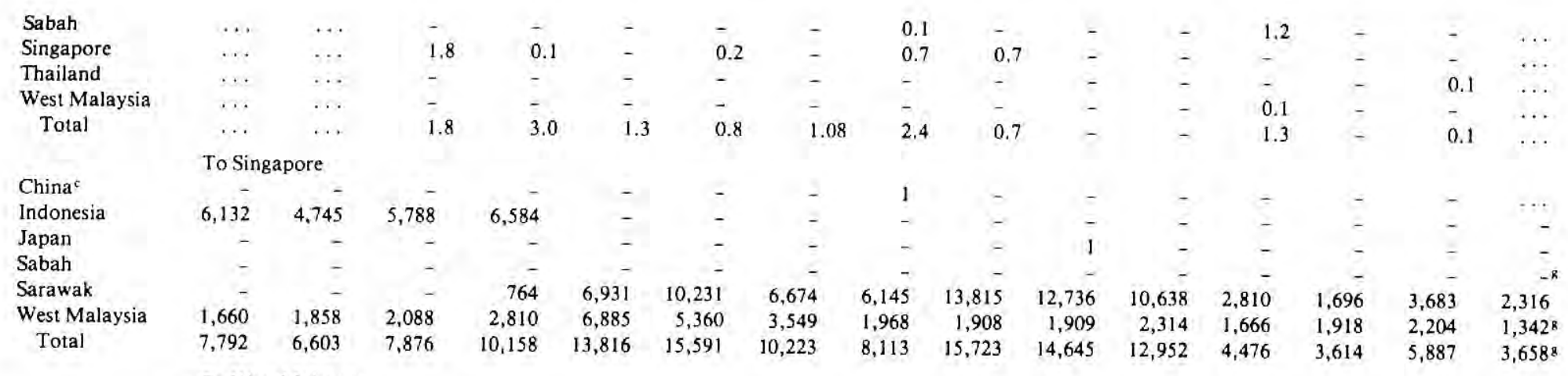

Indonesia

Hong Kong

Sarawak

Singapore

Thailand

United Kingdom

$\begin{array}{ll}0.4 & 2.5\end{array}$

Total

$0.4 \quad 2$

$\begin{array}{ll}0.8 & 2.7\end{array}$

2.3
$\overline{1.5}$
$\overline{7.2}$
0.3
-

$\begin{array}{cc}3.2 & 0.3 \\ - & - \\ - & - \\ - & - \\ 6.7 & 10.0 \\ - & - \\ \overline{9} .9 & \overline{10.3}\end{array}$

-
-
-
3.7
-
-
3.7

$\begin{array}{cccc}- & \ldots & \ldots & 0.2 \\ - & \ldots & \ldots & 4.3 \\ - & \ldots & \ldots & - \\ 1.8 & \ldots & \ldots & 50.8 \\ 1.8 & \ldots & \ldots & - \\ 0.4 & \ldots & \ldots & - \\ - & \ldots & \ldots & 0.1 \\ 4.0 & \ldots & \ldots & 55.4\end{array}$

$\begin{array}{ll}- & - \\ 4.3 & - \\ - & - \\ - & - \\ 0.6 & 2.8 \\ - & -\end{array}$

$2.5 \quad 1.0$

5.8

$506.0 \quad 226^{\mathrm{h}}$

SOURCES:

Office of State Secretary, Brunei, personal communication; State of Sarawak, Office of the Senior Statistician, Department of Statislics, personal communication; Republic of Singapore: 1957, 1958, 1959, 1960, 1961, 1962. (All for data on Brunei); State of Sabah, Department of Statistics, Statistics of External Trade: various ycars; State of Sarawak, Office of Director of Department of Agriculture, personal communication; Republic of Singapore n.d.; and West Malaysia, Office of the Chief Statistician,

NotF:

In M.T.; . . no data available; - zero imports.

a Data for 1960-1971 converted from long tons and rounded.

b. January through June only.

e Pcople's Republic.

a Probably derived from manioc.

c Data from Sarawak.

Department of Statistics, personal communication.

'Data from Singapore.

8 January through September only.

h Preliminary data. 
These come mainly from Singapore and West Malaysia. Other nations which have furnished imports are the People's Republic of China, Japan, Sabah, and Sarawak. The United Kingdom and the Netherlands have on occasion been suppliers. It should, however, be borne in mind that some Indonesian imports might represent return of spoiled exports by importing nations. This is known to have happened, for instance, between Japan and Sarawak (Chua pers. comm.).

The principal sago commodities entering international commerce within Southeast Asia are sago flour and meal, pearl sago, sago pith, and sago refuse. Only pearl sago is exported from the region in substantial amounts.

\section{Sago Flour and Meal}

Singapore is the principal importer of sago flour and meal within Southeast Asia. Although West Malaysia has been a constant supplier of this commodity-ranging from 10 to 35 percent of Singapore's imports of sago flour and meal from 1957-1974 (table 16) -it has always played a secondary role to other sources. Prior to 1964 , Singapore obtained the bulk of its sago flour and meal from Sumatra, Riau and Lingga. Subsequently Sarawak became the major supplier. In some years Singapore has purchased small quantities from Sabah and Thailand.

Compared with Singapore, other Southeast Asian nations within the sago-producing region are relatively insignificant importers of sago flour and meal (table 16). West Malaysia imports small quantities from Sarawak, the People's Republic of China, Thailand, Indonesia and Singapore. Brunei imports from Singapore, Sarawak, Thailand, West Malaysia and the People's Republic of China; and Sarawak's miniscule imports (table 17) come mostly from Brunei and Singapore.

Sarawak is the principal exporter of sago flour and meal (tables 18 and 19) with most of its exports now being sent to other Asian nations. Japan is at present Sarawak's leading partner in the sago flour and meal commerce, its imports having increased from 19 percent of Sarawak's total flour and meal exports in 1962 to 66 percent in 1973. Singapore is the second ranking importer of Sarawak sago flour and meal, increasing from 2 percent in 1963 to a high of 42 percent in 1969 and decreasing to 16 percent in 1973. 
TABLE 17. Sarawak: Imports of Sago Flour, 1870-1973

\begin{tabular}{|c|c|c|c|c|c|c|c|}
\hline Year & M.T.† & Year & M.T.† & Year & M.T.† & Year & M.T.T \\
\hline 1870 & - & 1896 & $\ldots$ & $1922^{b}$ & 0.1 & 1948 & $\ldots$ \\
\hline $1871^{\mathrm{a}}$ & $\ldots$ & 1897 & $\ldots$ & 1923 & $\ldots$ & 1949 & $\ldots$ \\
\hline $1872^{a}$ & $\ldots$ & 1898 & $\ldots$ & 1924 & $\ldots$ & 1950 & $\ldots$ \\
\hline $1873^{a}$ & $\ldots$ & 1899 & $\ldots$ & 1925 & $\ldots$ & 1951 & $\ldots$ \\
\hline $1874^{a}$ & $\ldots$ & $1900^{a}$ & $1,171,6$ & 1926 & $\ldots$ & 1952 & $\ldots$ \\
\hline $1875^{a}$ & $\ldots$ & 1901 & . & 1927 & $\ldots$ & 1953 & $\ldots$ \\
\hline $1876^{a}$ & - & 1902 & $\ldots$ & 1928 & $\ldots$ & $1954^{c}$ & 9.1 \\
\hline $1877^{a}$ & - & 1903 & 927.2 & 1929 & $\ldots$ & $1955^{c}$ & 1.0 \\
\hline $1878^{a}$ & - & 1904 & 938.2 & 1930 & $\ldots$ & $1956^{c}$ & 0.2 \\
\hline $1879^{a}$ & - & $1905^{b}$ & $1,268.6$ & 1931 & $\ldots$ & $1957^{c}$ & 1.0 \\
\hline $1880^{a}$ & - & $1906^{b}$ & 894.1 & 1932 & $\ldots$ & $1958^{c}$ & $*$ \\
\hline $1881^{\text {a }}$ & - & $1907^{b}$ & $1,051.0$ & 1933 & $\ldots$ & $1959^{c}$ & * \\
\hline $1882^{a}$ & - & $1908^{b}$ & $1,299.4$ & 1934 & $\ldots$ & $1960^{c}$ & $*$ \\
\hline $1883^{a}$ & - & $1909^{b}$ & $1,149.2$ & 1935 & $\ldots$ & $1961^{\mathrm{c}}$ & * \\
\hline $1884^{\mathrm{a}}$ & - & $1910^{b}$ & 871.9 & 1936 & $\ldots$ & $1962^{\mathrm{c}}$ & 1.8 \\
\hline $1885^{a}$ & - & $1911^{b}$ & 437.4 & 1937 & $\ldots$ & $1963^{c}$ & 3.0 \\
\hline 1886 & $\ldots$ & $1912^{b}$ & 718.6 & 1938 & $\ldots$ & $1964^{\mathrm{c}}$ & 1.4 \\
\hline $1887^{a}$ & - & $1913^{6}$ & 563.4 & 1939 & $\ldots$ & $1965^{\mathrm{c}}$ & 0.8 \\
\hline $1888^{a}$ & - & $1914^{b}$ & 582.7 & 1940 & $\ldots$ & $1966^{\mathrm{c}}$ & 1.1 \\
\hline $1889^{a}$ & - & $1915^{b}$ & $1,033.0$ & 1941 & $\ldots$ & $1967^{c}$ & 2.2 \\
\hline $1890^{a}$ & - & $1916^{b}$ & $1,104.6$ & 1942 & $\cdots$ & $1968^{c}$ & 0.7 \\
\hline $1891^{\mathrm{a}}$ & 114.9 & $1917^{\mathrm{b}}$ & 569.0 & 1943 & $\ldots$ & $1969^{c}$ & - \\
\hline 1892 & $\ldots$ & $1918^{b}$ & 361.0 & 1944 & $\ldots$ & $1970^{c}$ & - \\
\hline $1893^{a}$ & 489.5 & $1919^{b}$ & 766.4 & 1945 & $\ldots$ & $1971^{c}$ & 0.1 \\
\hline $1894^{a}$ & 631.0 & $1920^{b}$ & 335.7 & 1946 & $\ldots$ & $1972^{c}$ & 1.2 \\
\hline 1895 & $\ldots$ & $1921^{b}$ & 20.2 & 1947 & $\ldots$ & $1973^{c}$ & 0.1 \\
\hline
\end{tabular}

SOURCES:

a Sarawak Gazette, 2-28-1871:3; 2-15-1872:4; 3-2-1874:3; 3-16-1875:4; 6-24-1876:5; $8-25-1877: 67 ; 6-24-1878: 48 ; 5-23-1879: 36 ; 3-31-1880: 19 ; 4-1-1881: 37-8 ; 5-1-1882$ : $33-4 ; 4-2-1883: 32-3 ; 4-1-1884: 28-9 ; 5-1-1885: 51-2 ; 4-1-1886: 67-8 ; 5-1-1888: 63-4 ; 6-1-$ $1889: 90-1 ; 5-1-1890: 70-1 ; 5-1-1891: 79-80 ; 7-1-1892: 133-4 ; 8-1-1894: 133-4 ; 6-1-1895$ : $113-4 ; 4-1-1901: 78 ; 5-2-1903: 100$.

b Sarawak, Annual Report of the Treasury and the Post, Shipping and Customs Departments.

c State of Sarawak, Department of Statistics, Office of the Senior Statistician, personal communication.

Notes:

- Magnitude of zero; . . . no data available; * less than 0.01 M.T.

† Converted from pikuls and rounded. 
TABLE 18. Direction of Export Trade in Sago Flour and Meal, 1960-1974 (metric tons)

\begin{tabular}{|c|c|c|c|c|c|c|c|c|c|c|c|c|c|c|c|}
\hline \multicolumn{16}{|l|}{ Importing } \\
\hline Country & 1960 & 1961 & 1962 & 1963 & 1964 & 1965 & 1966 & 1967 & 1968 & 1969 & 1970 & 1971 & 1972 & 1973 & 1974 \\
\hline & \multicolumn{15}{|c|}{ From Sabah ${ }^{a}$} \\
\hline Philippines & $\ldots$ & $\ldots$ & $\ldots$ & $\ldots$ & $\ldots$ & 0.5 & 0.1 & - & - & 6.4 & - & - & - & 1.5 & $\ldots$ \\
\hline Sarawak & $\ldots$ & $\ldots$ & $\ldots$ & $\ldots$ & $\ldots$ & 0.3 & - & 0.1 & - & - & - & - & - & - & $\ldots$ \\
\hline \multirow[t]{2}{*}{ Total } & $\ldots$ & $\cdots$ & $\cdots$ & $\cdots$ & $\cdots$ & 0.8 & 0.1 & 0.1 & - & 6.4 & - & - & - & 1.5 & $\ldots$ \\
\hline & \multicolumn{15}{|c|}{ From Sarawak ${ }^{b}$} \\
\hline Australia & $\ldots$ & $\ldots$ & - & - & - & - & - & 0.5 & - & - & - & - & - & - & $\cdots$ \\
\hline Belgium $^{\circ}$ & $\ldots$ & $\ldots$ & 762.0 & - & 863.6 & 569.0 & 762,0 & 965.2 & - & 25.4 & - & - & - & - & $\ldots$ \\
\hline Brunei & $\ldots$ & $\ldots$ & - & - & - & 1.5 & 0.2 & - & 1.2 & 1.4 & 0.7 & 0.7 & 2.4 & 2.4 & $\ldots$ \\
\hline Denmark & $\ldots$ & $\ldots$ & - & - & 0.6 & - & - & - & - & - & - & - & - & - & $\ldots$ \\
\hline France & $\ldots$ & $\ldots$ & 405.5 & - & - & - & - & - & - & - & - & - & - & - & $\cdots$ \\
\hline Hong Kong & $\ldots$ & $\ldots$ & 113.2 & 25.4 & 302.2 & 243.1 & 233.7 & - & 452.3 & 302.4 & 981.5 & 778.7 & 806.6 & $1,210.3$ & $\ldots$ \\
\hline Indonesia & $\cdots$ & $\ldots$ & 0.2 & 0.1 & - & - & - & 14.3 & 39.9 & 4.7 & 54.3 & 22.5 & 6.9 & 76.2 & $\ldots$ \\
\hline Iraq & $\ldots$ & $\ldots$ & - & - & - & - & 76.2 & - & 101.6 & - & - & - & - & - & $\ldots$ \\
\hline Japan & $\ldots$ & $\ldots$ & $6,138.4$ & $19,613.0$ & $22,506.5$ & $20,722.6$ & $18,394.6$ & $22,905.3$ & $18,263.6$ & $13,578,7$ & $11,839.4$ & $15,646.5$ & $12,427.1$ & $14,932,3$ & $\cdots$ \\
\hline Kenya & $\ldots$ & $\ldots$ & - & - & - & - & 473.5 & 162.6 & 203.2 & 40.6 & - & - & - & - & $\ldots$ \\
\hline Mozambique & $\ldots$ & $\ldots$ & - & - & - & - & - & - & 66.0 & - & - & - & - & - & $\ldots$ \\
\hline Netherlands & $\ldots$ & $\ldots$ & $6,569.8$ & $1,549.5$ & $1,884.7$ & 5.1 & - & 762.0 & 203.2 & 304.8 & - & - & - & - & $\ldots$ \\
\hline New Zealand & $\ldots$ & $\ldots$ & - & - & 10.2 & - & - & - & - & - & - & - & - & - & $\ldots$ \\
\hline Nigeria & $\cdots$ & $\ldots$ & - & 40.6 & - & - & - & - & - & - & - & - & - & - & \\
\hline Sabah & $\cdots$ & $\ldots$ & - & - & - & - & - & - & 5.5 & 5.5 & - & - & - & - & $\ldots$ \\
\hline Saudi Arabia & $\ldots$ & $\ldots$ & 20.3 & - & - & - & - & - & - & - & - & - & - & - & $\ldots$ \\
\hline Singapore & $\ldots$ & $\ldots$ & 10.2 & 653.2 & $7,760.1$ & $9,832.5$ & $5,616.8$ & $2,925.0$ & $11,625.3$ & $12,245.9$ & $10,462.8$ & $2,959.9$ & $2,177,0$ & $3,642,3$ & $\ldots$ \\
\hline Spain & $\ldots$ & $\ldots$ & - & 406.4 & 50.8 & 264.2 & 162.6 & 304.8 & 406.4 & 203.2 & 152.4 & 406.4 & 127.0 & 127.0 & \\
\hline
\end{tabular}




\begin{tabular}{|c|c|c|c|c|c|c|c|c|c|c|c|c|c|c|}
\hline South Africa & $\ldots$ & $\ldots$ & 182.9 & 203.2 & - & 416.6 & - & - & - & - & - & - & - & - \\
\hline Taiwan & $\ldots$ & $\ldots$ & - & 22.4 & $7,311.1$ & $3,552.8$ & - & - & - & - & - & - & - & - \\
\hline United Kingdom & $\cdots$ & $\ldots$ & $17,782.1$ & $17,739.9$ & $17,649.7$ & $9,254.4$ & $12,197.1$ & $8,472.9$ & $4,826,0$ & $2,387.6$ & $5,029.7$ & $2,819.4$ & $2,443.5$ & $3,092.5$ \\
\hline West Germany & $\ldots$ & $\ldots$ & 50.8 & 25.4 & 50.8 & - & - & - & - & - & - & - & - & - \\
\hline West Malaysia & $\ldots$ & $\ldots$ & - & - & - & - & - & 30.5 & 355.6 & 50.8 & - & 471.6 & 426.9 & 656.1 \\
\hline O.C. Middle East & .. & $\ldots$ & - & - & 25.4 & - & - & - & - & - & - & - & - & - \\
\hline Total & $\ldots$ & $\ldots$ & $32,036.0$ & $40,279.1$ & $58,415.7$ & $44,861.8$ & $37,916.7$ & $36,543.1$ & $36,549.8$ & $29,151.1$ & $28,520.8$ & $23,105.7$ & $18,417.4$ & $23,739.1$ \\
\hline
\end{tabular}

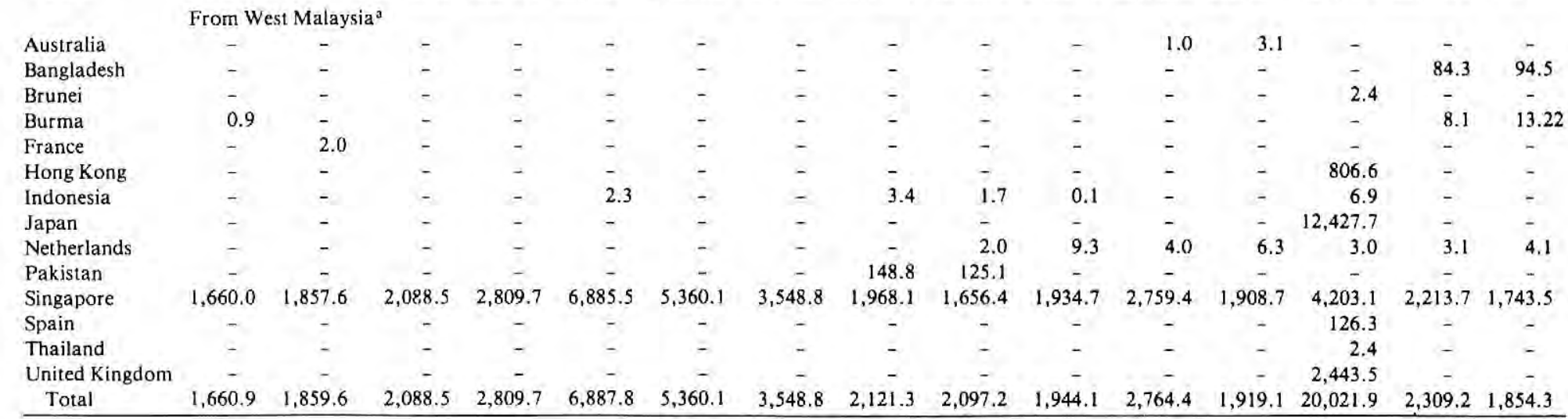
SOURCES:

State of Sabah, Department of Statistics, Statistics of External Trade, Sabah; State of Sarawak, Office of Senior Statistician, Department of Statistics, personal communication; and West Malaysia, Office of Chief Statistician, Department of Statistics, personal communication. NOTES:

... No data available; - zero exports.

a Data converted from long tons and rounded.

b 1962 and 1963 data converted from pikuls and rounded; remainder from long tons.

c1ncluding Luxembourg. 
TABLE 19. Sarawak: Exports of Sago Flour, 1870-1973

\begin{tabular}{|c|c|c|c|c|c|}
\hline Year & M.T. & Year & M.T. & Year & M.T. \\
\hline $1870^{\mathrm{a}}$ & $\cdots$ & 1895 & $\ldots$ & $1920^{b}$ & $15,744.1$ \\
\hline $1871^{\text {a }}$ & $\ldots$ & 1896 & $\ldots$ & $1921^{b}$ & $18,243.9$ \\
\hline $1872^{a}$ & $\ldots$ & $1897^{a}$ & $14,732.3$ & $1922^{b}$ & $23,506.2$ \\
\hline $1873^{a}$ & $\ldots$ & $1898^{\mathrm{a}}$ & $15,191.9$ & $1923^{b}$ & $19,471.7$ \\
\hline $1874^{a}$ & $\ldots$ & $1899^{a}$ & $13,848.7$ & $1924^{b}$ & $21,303.3$ \\
\hline $1875^{\mathrm{a}}$ & $\ldots$ & $1900^{\mathrm{a}}$ & $14,283.3$ & $1925^{b}$ & $18,542.5$ \\
\hline 1876 & $\ldots$ & $1901^{a}$ & $11,858.3$ & $1926^{b}$ & $15,806.2$ \\
\hline $1877^{a}$ & $\ldots$ & $1902^{a}$ & $10,957.3$ & $1927^{c}$ & $16,068.9$ \\
\hline $1878^{a}$ & $\ldots$ & $1903^{b}$ & $11,755.3$ & $1928^{c}$ & $14,649.4$ \\
\hline $1879^{a}$ & $\ldots$ & $1904^{b}$ & $15,738.4$ & $1929^{b}$ & $12,322.6$ \\
\hline $1880^{a}$ & $\ldots$ & $1905^{b}$ & $13,580.8$ & $1930^{b}$ & $15,828.3$ \\
\hline $1881^{a}$ & $6,673.6$ & $1906^{b}$ & $16,205.5$ & $1931^{d}$ & $14,011.7$ \\
\hline $1882^{a}$ & $5,748.8$ & $1907^{b}$ & $20,961.1$ & $1932^{\circ}$ & $22,052.3$ \\
\hline $1883^{a}$ & $6,674.6$ & $1908^{b}$ & $22,279.1$ & $1933^{e}$ & $24,688.4$ \\
\hline $1884^{a}$ & $5,783.5$ & $1909^{b}$ & $22,353.2$ & $1934^{c}$ & $17,484.5$ \\
\hline 1885 & $5,865.6$ & $1910^{b}$ & $20,479.9$ & $1935^{\mathrm{e}}$ & $19,677.8$ \\
\hline 1886 & $\ldots$ & $1911^{b}$ & $20,028.3$ & $1936^{e}$ & $23,013.7$ \\
\hline $1887^{a}$ & $8,980.0$ & $1912^{b}$ & $19,381.9$ & $1937^{\mathrm{f}}$ & $23,504,0$ \\
\hline $1888^{a}$ & $8,466.7$ & $1913^{b}$ & $16,184.4$ & $1938^{\mathrm{B}}$ & $15,517.1$ \\
\hline $1889^{a}$ & $9,600.7$ & $1914^{b}$ & $14,215.7$ & $1939^{\mathrm{e}}$ & $25,371.6$ \\
\hline $1890^{a}$ & $9,729.7$ & $1915^{b}$ & $20,520.8$ & $1940^{e}$ & $23,513.0$ \\
\hline $1891^{\mathrm{a}}$ & $12,843.0$ & $1916^{b}$ & $19,851.6$ & 1941 & $\ldots$ \\
\hline 1892 & $\ldots$ & $1917^{b}$ & $12,744,8$ & 1942 & $\ldots$ \\
\hline $1893^{a}$ & $16,548.5$ & $1918^{b}$ & $13,497.8$ & 1943 & $\ldots$ \\
\hline $1894^{\text {a }}$ & $15,701.1$ & $1919^{b}$ & $23,365.1$ & 1944 & $\ldots$ \\
\hline
\end{tabular}


TABLE 19. (cont.)

\begin{tabular}{|c|c|c|c|c|c|}
\hline Year & M.T. & Year & M.T. & Year & M.T. \\
\hline 1945 & & $1955^{h}$ & $10,028.9$ & $1965^{1}$ & $44,861.7$ \\
\hline $1946^{\mathrm{h}}$ & $5,128.8$ & $1956^{\mathrm{h}}$ & $12,777.2$ & $1966^{\mathrm{i}}$ & $37,916.5$ \\
\hline $1947^{\text {h }}$ & $39,848.5$ & $1957^{\mathrm{h}}$ & $12,983.5$ & $1967^{i}$ & $36,543.1$ \\
\hline $1948^{\mathrm{h}}$ & $50,547.0$ & $1958^{\mathrm{h}}$ & $16,772.1$ & $1968^{\mathrm{i}}$ & $36,549.0$ \\
\hline $1949^{\mathrm{h}}$ & $27,515.3$ & $1959^{\mathrm{h}}$ & $17,991.3$ & $1969^{i}$ & $29,151.0$ \\
\hline $1950^{\mathrm{h}}$ & $28,694.9$ & $1960^{\mathrm{h}}$ & $20,286.5$ & $1970^{\mathrm{i}}$ & $28,520.8$ \\
\hline $1951^{\mathrm{h}}$ & $24,328.1$ & $1961^{\mathrm{h}}$ & $24,846.3$ & $1971^{i}$ & $23,105.7$ \\
\hline $1952^{\mathrm{h}}$ & $22,980.9$ & $1962^{\mathrm{h}}$ & $32,126.9$ & $1972^{i}$ & $18,417.3$ \\
\hline $1953^{\mathrm{h}}$ & $16,330.2$ & $1963^{i}$ & $40,279.0$ & $1973^{i}$ & $22,526.4$ \\
\hline $1954^{\mathrm{h}}$ & $12,743.7$ & $1964^{i}$ & $58,435.4$ & & \\
\hline
\end{tabular}

SOURCES:

a Sarawak Gazette, 2-28-1871:3; 2-15-1871:4; 2-17-1873:5; 3-2-1874:3; 3-16-1875:4; 6-24-1876:5; 6-24-1878:48; 5-23-1879:36; 3-31-1880:19; 4-1-1881:37-8; 5-1-1882:33-4; $4-2-1883: 32-3 ; 4-1-1884: 28-9 ; 5-1-1885: 51-2 ; 4-1-1886: 67-8 ; 5-1-1888: 63-4 ; 6-1-1889$ : 90-1; 5-1-1890:70-1; 5-1-1891:79-80; 7-1-1892:133-4; 4-1-1901:78; 5-2-1903:100.

b Sarawak, Annual Report of the Department of Trade and Customs.

c Supplement to the Sarawak Government Gazette, July 16, 1929.

d Sarawak, Administration Report for 1931.

- Sarawak, Department of Trade and Customs and Shipping Office, Annual Statistics and Accounts.

if Supplement to the Sarawak Government Gazette, May 2, 1938.

i Supplement to the Sarawak Government Gazette, June 1, 1939.

h Government of Sarawak, Department of Agriculture, Annual Report 1962:135.

i State of Sarawak, Department of Statistics, Office of Senior Statistician, personal communication.

NoTES:

Data include re-exports. Those for 1881-1940 are converted from pikuls; for 1946-1973 from long tons. All figures have been rounded. 
TABLE 20. Hong Kong: Direction of Trade in Sago, 1931-1974 (current Hong Kong dollars)

\begin{tabular}{|c|c|c|c|c|c|c|c|c|c|c|c|c|}
\hline Country of Origin & 1931 & 1932 & 1933 & 1934 & 1935 & 1936 & 1937 & 1938 & 1939 & 1940 & $\begin{array}{l}1941- \\
1951\end{array}$ & $\begin{array}{l}1952- \\
1963 \\
\end{array}$ \\
\hline Burma & - & - & - & - & - & - & - & 270 & 2,240 & - & $\ldots$ & $\ldots$ \\
\hline China ${ }^{a}$ & 918 & 110 & - & 2,647 & - & - & 220 & - & - & 332 & $\ldots$ & $\cdots$ \\
\hline India & 41 & - & 13 & - & - & - & - & - & - & - & $\cdots$ & $\ldots$ \\
\hline Indo-Chinab & - & 230 & - & 3,790 & - & - & - & 120 & 420 & 4,800 & $\cdots$ & $\cdots$ \\
\hline Indonesia & 4,010 & 11,214 & 9,009 & 43,371 & 16,648 & 14,770 & 23,693 & 27,010 & 5,350 & - & $\cdots$ & $\cdots$ \\
\hline Japan & - & - & - & 669 & - & - & - & - & - & - & $\ldots$ & $\cdots$ \\
\hline Macao & 20 & 232 & - & 214 & 61 & 48 & - & - & - & - & $\cdots$ & $\cdots$ \\
\hline Malaysiac & 168,301 & 125,856 & 46,811 & 40,952 & 36,158 & 58,483 & 52,301 & 45,271 & 63,765 & 86,567 & $\cdots$ & $\cdots$ \\
\hline Sarawak & - & - & - & - & - & - & - & - & - & - & $\cdots$ & $\cdots$ \\
\hline Singapore & - & - & - & - & - & - & - & - & - & - & $\cdots$ & $\cdots$ \\
\hline Thailand & - & 1,893 & - & - & - & - & - & - & - & - & $\ldots$ & $\cdots$ \\
\hline United Kingdom & - & - & - & - & 65 & 49 & - & - & - & 48 & $\ldots$ & $\cdots$ \\
\hline U.S.A. & 22 & - & - & - & 123 & 51 & 252 & 193 & 151 & 63 & $\cdots$ & $\cdots$ \\
\hline Total & 173,312 & 139,535 & 55,833 & 91,673 & 53,055 & 73,401 & 76,466 & 72,864 & 71,926 & 91,810 & $\ldots$ & $\cdots$ \\
\hline
\end{tabular}




\begin{tabular}{|c|c|c|c|c|c|c|c|c|c|c|c|c|}
\hline Importing Country & 1931 & 1932 & 1933 & 1934 & 1935 & 1936 & 1937 & 1938 & 1939 & 1940 & $\begin{array}{l}1941- \\
1951\end{array}$ & $\begin{array}{l}1952- \\
1964 \\
\end{array}$ \\
\hline British Commonwealth & 1 & - & - & - & 8 & 29 & 127 & 123 & 481 & 17 & $\cdots$ & $\cdots$ \\
\hline Central America d & 271 & 155 & 191 & 207 & - & - & 65 & 142 & - & 70 & $\ldots$ & $\cdots$ \\
\hline China $^{a}$ & 115,110 & 88,568 & 32,600 & 31,596 & 20,566 & 54,304 & 76,159 & 107,236 & 110,877 & 10,118 & $\cdots$ & $\cdots$ \\
\hline Indo-China ${ }^{b}$ & 822 & 728 & 491 & 647 & 370 & 1,247 & 513 & 387 & 471 & 530 & $\cdots$ & $\cdots$ \\
\hline Japan & 16,577 & 11,538 & 7,374 & 10,972 & 6,425 & 9,906 & 11,030 & 2,635 & - & - & $\cdots$ & $\ldots$ \\
\hline Macao & 21,767 & 15,593 & 14,111 & 13,950 & 9,731 & 5,335 & 6,625 & 8,647 & 28,528 & 29,872 & $\cdots$ & $\ldots$ \\
\hline Netherlands & - & - & - & - & - & - & - & - & - & - & $\ldots$ & $\ldots$ \\
\hline Philippines & 2,053 & 773 & 51 & 638 & 138 & 3,359 & 5,140 & 2,727 & 1,278 & 1,014 & $\ldots$ & $\ldots$ \\
\hline Sabah & - & - & - & - & - & - & - & 24 & 64 & 124 & $\cdots$ & $\ldots$ \\
\hline Singapore & $\ldots$ & $\ldots$ & $\ldots$ & $\ldots$ & $\ldots$ & $\ldots$ & $\cdots$ & $\ldots$ & $\cdots$ & $\ldots$ & $\ldots$ & $\ldots$ \\
\hline South America & 3 & 31 & 50 & 59 & - & - & - & 57 & 140 & 90 & $\ldots$ & $\cdots$ \\
\hline U.S.A. & 195 & 112 & 114 & 70 & - & - & - & - & - & 148 & $\ldots$ & $\cdots$ \\
\hline Others & 555 & 220 & 206 & $I, 24 I$ & 427 & 242 & 4,775 & 152 & 11 & 615 & $\cdots$ & $\cdots$ \\
\hline Total & 157,416 & 117,718 & 55,188 & 59,380 & 37,665 & 74,422 & 104,434 & 122,130 & 141,850 & 42,598 & $\ldots$ & $\ldots$ \\
\hline
\end{tabular}


TABLE 20. (cont.)

\begin{tabular}{|c|c|c|c|c|c|c|c|c|c|c|c|}
\hline \multicolumn{12}{|l|}{ A: Imports } \\
\hline Country of Origin & 1964 & 1965 & 1966 & 1967 & 1968 & 1969 & 1970 & 1971 & 1972 & 1973 & 1974 \\
\hline Burma & - & - & - & - & - & - & - & - & - & - & - \\
\hline China $^{a}$ & 4,500 & 2,250 & 6,250 & 7,725 & 9,420 & 3,269 & 7,143 & 1,119 & 9,329 & 24,398 & 54,196 \\
\hline India & - & 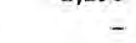 & - & - & - & - & - & - & - & - & - \\
\hline Indo-China ${ }^{b}$ & - & - & - & - & - & - & - & - & - & - & - \\
\hline Indonesia & 10,500 & 880,497 & 275,050 & 58,330 & - & - & - & - & - & - & 109,000 \\
\hline Japan & - & - & - & - & - & - & - & - & - & - & - \\
\hline Macao & - & - & - & - & - & - & - & - & - & - & - \\
\hline Malaysias & - & - & - & - & - & - & - & - & - & - & - \\
\hline Sarawak & 81,140 & 62,700 & 73,885 & - & 51,400 & 100,630 & 119,577 & 324,644 & 293,658 & 523,500 & 143,313 \\
\hline Singapore & 405,349 & 97,284 & 108,299 & 748,364 & 250,887 & 254,779 & 156,079 & 102,900 & 99,570 & 9,142 & - \\
\hline Thailand & - & 15,300 & - & - & 1,810 & 5,530 & 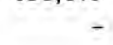 & 3,830 & 2,200 & - & - \\
\hline United Kingdom & - & - & - & - & - & - & - & - & - & - & - \\
\hline U.S.A. & - & - & - & - & - & - & - & - & - & - & - \\
\hline Total & 501,489 & $1,058,031$ & 463,484 & 814,419 & 313,517 & 364,208 & 289,942 & 432,493 & 404,757 & 557,040 & 306,509 \\
\hline
\end{tabular}


B: Re-exports

\begin{tabular}{|c|c|c|c|c|c|c|c|c|c|c|}
\hline Importing Country & 1965 & 1966 & 1967 & 1968 & 1969 & 1970 & 1971 & 1972 & 1973 & 1974 \\
\hline British Commonwealth & - & - & - & 70 & 52 & 413 & 556 & 856 & 467 & 1,432 \\
\hline Central Americad & - & - & - & - & 110 & - & - & 214 & 120 & 150 \\
\hline China $^{a}$ & - & - & - & - & - & - & - & - & - & - \\
\hline Indo-China ${ }^{b}$ & - & - & - & - & - & - & - & - & - & - \\
\hline Japan & - & - & - & - & - & - & - & 840 & - & 450 \\
\hline Macao & - & - & 3,000 & - & - & - & - & - & - & - \\
\hline Netherlands & 2,377 & - & - & - & - & - & - & - & 260 & - \\
\hline Philippines & - & - & 54,000 & - & - & - & - & - & - & - \\
\hline Sabah & - & - & - & - & - & - & - & - & - & - \\
\hline Singapore & 220,225 & 8,150 & - & - & - & - & - & 2,047 & - & - \\
\hline South America & - & - & - & 72 & 144 & - & - & - & - & - \\
\hline U.S.A. & - & - & - & - & - & - & 871 & 1,341 & 218 & $553^{e}$ \\
\hline Others & - & - & - & - & - & - & - & - & - & - \\
\hline Total & 222,602 & 8,150 & 57,000 & 142 & 306 & 413 & 1,427 & 5,298 & 1,065 & 2,585 \\
\hline
\end{tabular}

SOURCE:

Hong Kong, Commissioner for Census and Statistics, personal communication. NOTES:

- Zero trade; . . . no data available (1941-1951: impact of WW2; 1952-1964: sago data not segregated)

a People's Republic of China. Source provides data for "North," "Middle," and "South China," together with Kwong Chow Wan (Bay of Canton).

b Those territories formerly controlled by the French.

c Including Singapore.

d Including Mexico.

e Including U.S. Oceanic territories. 
Hong Kong, which took approximately 1 percent of Sarawak's exports in that commodity during the period 1944-1969, has now gradually increased its share to some 5 percent, and is the fourth most important destination for exports of Sarawak sago flour and meal (table 20). Other Asian nations are trading partners of only minor importance; Brunei regularly takes small quantities, as does Indonesia. Trade with Sabah is erratic as is that with Taiwan.

Traditionally the United Kingdom was Sarawak's principal buyer of sago flour and meal. In recent years, the United Kingdom has become the third ranking importer, as Sarawak's sago exports to the United Kingdom declined from 56 percent (1962) to 14 percent (1973), concomitant with the increased importance of the Japanese market. With the exception of regular small shipments of flour and meal to the Netherlands and Spain, Sarawak's exports of this commodity to other nations both are sporadic and have a wide geographical distribution.

Reexport trade in sago flour and meal has historically been dominated by Singapore (table 21). This trade was maintained with more than 50 countries-more than twice the number of Sarawak's trading partners-but this has declined drastically since the early 1960 s (table 22). Traditionally, the bulk of Singapore's exports went to the United Kingdom, which imported 71 percent $(27,000 \mathrm{MT})$ of the total in 1963 , the year of maximum exports in the time-series considered. The Netherlands, too, has been a fairly important and consistent importer. Within Asia, Pakistan has remained a major market, whereas Japan imported large quantities of flour and meal from Singapore only in 1968, 1969, and 1970, when it took 62,71 , and 68 percent of total exports respectively. For the remainder of this trade Singapore exports only relatively small shipments to a geographically diverse range of importers, mainly within the British Commonwealth.

West Malaysia's exports are relatively insignificant, being directed mostly to Singapore, except for a single year's trade involving relatively large amounts, with Japan in 1972 (62 percent of total exports) and with the United Kingdom during the same year (12 percent of total exports). Some quantities are occasionally shipped to other, mostly Asian, trading partners. 
TABLE 21. Singapore: Exports of Sago Flour and Pearl Sago, 1923-1974

\begin{tabular}{|c|c|c|c|c|c|}
\hline Year & $\begin{array}{l}\text { Flour } \\
(\text { M.T. })^{\mathrm{a}}\end{array}$ & $\begin{array}{l}\text { Pearl } \\
(\text { M.T. })^{a}\end{array}$ & Year & $\begin{array}{l}\text { Flour } \\
(\text { M.T. })^{a}\end{array}$ & $\begin{array}{l}\text { Pearl } \\
(\mathrm{M}, \mathrm{T},)^{\mathrm{a}}\end{array}$ \\
\hline 1923 & 37,592 & $\ldots$ & 1949 & $\ldots$ & $\ldots$ \\
\hline 1924 & 56,896 & $\cdots$ & 1950 & 24,504 & 1,598 \\
\hline 1925 & 50,800 & $\ldots$ & 1951 & 49,575 & 3,370 \\
\hline 1926 & 30,988 & $\ldots$ & 1952 & 38,442 & 5,821 \\
\hline 1927 & 42,672 & $\ldots$ & 1953 & 52,811 & 5,413 \\
\hline 1928 & 42,875 & $\ldots$ & 1954 & 45,961 & 3,807 \\
\hline 1929 & 44,704 & $\ldots$ & 1955 & 34,494 & 4,109 \\
\hline 1930 & 53,938 & $\ldots$ & 1956 & 32,427 & 3,733 \\
\hline 1931 & 47,321 & $\ldots$ & 1957 & 28,322 & 3,721 \\
\hline 1932 & 67,314 & $\ldots$ & 1958 & 21,994 & 3,180 \\
\hline 1933 & 64,522 & $\ldots$ & 1959 & 26,389 & 2,882 \\
\hline 1934 & 52,635 & $\ldots$ & 1960 & 28,886 & 3,068 \\
\hline 1935 & 65,940 & $\ldots$ & 1961 & 29,711 & 2,587 \\
\hline 1936 & 72,131 & $\ldots$ & 1962 & 24,115 & $2,958^{b}$ \\
\hline 1937 & 71,698 & 3,832 & 1963 & 37,642 & $2,573^{\circ}$ \\
\hline 1938 & 46,216 & 4,198 & 1964 & 12,021 & $2,096^{b}$ \\
\hline 1939 & 68,129 & 3,910 & 1965 & 9,997 & $1,873^{b}$ \\
\hline 1940 & 63,240 & 4,963 & 1966 & 5,454 & $1,934^{b}$ \\
\hline 1941 & $\ldots$ & $\ldots$ & 1967 & 17,857 & $1,821^{b}$ \\
\hline 1942 & $\ldots$ & $\ldots$ & 1968 & 21,831 & $1,874^{b}$ \\
\hline 1943 & $\ldots$ & $\ldots$ & 1969 & 20,484 & $1,506^{b}$ \\
\hline 1944 & $\ldots$ & $\ldots$ & 1970 & 15,809 & $915^{b}$ \\
\hline 1945 & $\ldots$ & $\ldots$ & 1971 & 6,741 & $998^{b}$ \\
\hline 1946 & $\ldots$ & $\ldots$ & 1972 & 2,653 & $1,114^{b}$ \\
\hline 1947 & $\ldots$ & $\cdots$ & 1973 & 3,291 & $904^{b}$ \\
\hline 1948 & $\ldots$ & $\ldots$ & 1974 & $1,966^{c}$ & $857^{\mathrm{b}, \mathrm{c}}$ \\
\hline
\end{tabular}

SOURCES:

The Singapore Chamber of Commerce, Report for the Year 1926 (etc.). Singapore: Fraser and Neave, Ltd. (1927-1929); Printers, Ltd. (1931-1933); Straits Times Press, Ltd. (1936-1965).

Republic of Singapore (for the years 1966-1974).

Notes:

a Converted from long tons.

b Converted from cwt.

c January through September only. 


\section{Sago Refuse}

Sago refuse comprises a minor commodity in the international sago trade. Singapore is the principal importer of refuse. West Malaysia and Brunei import only small quantities, and none is received by either Sarawak or Sabah.

In recent years almost all the sago refuse imported by Singapore originates in West Malaysia (table 23). Only small quantities sporadically arrive from Sarawak. Formerly, the nearby Indonesian archipelago of Riau and Lingga together with Sumatra, Bali, and Lombok (Republic of Singapore 1963 and 1964), were important sources of sago refuse, but this trade is now defunct.

West Malaysia ranks second in sago refuse imports, which are derived mostly from Singapore (as reexports) and Indonesia. In some years small quantities are also imported from the People's Republic of China and Thailand. Formerly, Sumatra was a large source of most of West Malaysia's refuse (West Malaysia 1968). West Malaysian import statistics do not distinguish those refuse imports reexported to Singapore. Brunei is only a minor participant in this trade, most of its refuse coming from neighboring Sarawak and, in the last two years, as reexports from Singapore.

Export trade of sago refuse is reported by West Malaysia and Sarawak (table 24). In recent years almost all of West Malaysian exports have gone to Singapore, while Sarawak's miniscule sago refuse exports have gone to neighboring Brunei. These data in some instances provide statistics not reported by the importing country. Sabah plays virtually no role in trade in this commodity.

\section{Sago Pith}

Only relatively small quantities of sago pith have, historically, entered into international commerce within Southeast Asia, as most producing countries prefer to process sago, either partly or completely, before it leaves their shores. This is exemplified by data for Sarawak (table 25). Again, Singapore is the main importer. Formerly Singapore derived the bulk of its imports of pith from Sumatra, but in this commodity, too, trade has ceased. What little is now imported by Singapore comes from West Malaysia, and occasionally from Sarawak (table 26). 
Small quantities of pith are imported, and either exported, or reexported by Brunei and Sarawak. Brunei exports or reexports pith to Sarawak and occasionally to Sabah (table 27), and now imports from Singapore and Thailand. Formerly Brunei imported pith from Sarawak. Sarawak's miniscule trade in sago pith includes a single year's import from Thailand and a sporadic trade with neighboring Brunei and Sabah, countries with which it has both an import and export trade in this commodity. West Malaysia imports minute quantities of pith from several nations, whereas Sabah depends for its imports on Brunei and Sarawak alone.

\section{Pearl Sago}

Pearl sago is exported by Singapore and West Malaysia with the former historically dominating the trade. Singapore's position has progressively eroded since 1957 (table 28), whereas West Malaysian exports of this commodity have gradually increased, and in 1974 exceeded those of Singapore (table 29). Singapore's trade in pearl sago is distributed among more than 50 nations. The United Kingdom has consistentiy been the largest single importer of Singapore's pearl sago exports, accounting for some 83 percent of the total in 1968, and the time-series low of 49 percent in 1974. Singapore is also a small importer of pearl sago (table 30) apparently for reexport.

West Malaysian exports of pearl sago go mostly to Singapore. Occasionally fairly substantial amounts have been shipped to $\mathrm{Pa}$ kistan, Sri Lanka, Burma, Bahrein, and the United Kingdom and, in the last two years, to Bangladesh. Minute quantities of pearl sago are imported into West Malaysia mostly from the People's Republic of China, Indonesia, Singapore and Thailand.

Sarawak, whose imports over the past 12 years have ranged between 15 and $24 \mathrm{MT}$, derives most of its supply of pearl sago from Singapore, Thailand, West Malaysia, and the People's Republic of China. Trade in pearl sago has never been important for Sarawak (tables 31 and 32). Brunei's chief supplier is Singapore, with some imports coming from a range of countries, but in particular from Thailand and Sarawak. 
TABLE 22. Singapore: Direction of Export Trade in Sago Flour and Meal, 19571974 (metric tons)

\begin{tabular}{|c|c|c|c|c|c|c|c|c|c|}
\hline $\begin{array}{l}\text { Importing } \\
\text { Country }\end{array}$ & $1957^{a}$ & $1958^{a}$ & $1959^{a}$ & $1960^{\mathrm{a}}$ & $1961^{a}$ & $1962^{a}$ & $1963^{a}$ & $1964^{\mathrm{a}}$ & $1965^{a}$ \\
\hline Australia & - & 3.1 & 3.1 & 11.3 & 2.0 & 18.5 & 12.7 & 76.2 & 169.7 \\
\hline Bangladeshc & - & - & - & - & - & - & - & - & - \\
\hline Belgium ${ }^{d}$ & - & - & 421.6 & 756.9 & 25.4 & - & - & - & - \\
\hline \multicolumn{10}{|l|}{ British Caribbean } \\
\hline Federation & - & - & - & - & - & - & - & 1.0 & - \\
\hline Brunei & 0.3 & 0.1 & 0.3 & 0.9 & 1.7 & 0.7 & 0.3 & 1.0 & - \\
\hline Burma & 48.5 & - & 36.3 & 233.7 & - & 181.4 & - & - & - \\
\hline Cambodia & - & - & - & - & - & - & - & - & - \\
\hline Canada & - & - & - & - & - & - & - & - & - \\
\hline Christmas Island & - & - & - & - & - & 2.2 & 1.5 & - & 1.0 \\
\hline \multicolumn{10}{|l|}{ Colombia and } \\
\hline Ecuador & - & - & 10.0 & - & - & - & - & - & - \\
\hline Czechoslovakia & - & 1.5 & - & - & - & - & - & - & - \\
\hline Denmark & 12.7 & 13.2 & 5.1 & 12.7 & 11.7 & 1.5 & 7.1 & 5.1 & 7.1 \\
\hline Eire & 45.7 & 132.1 & 157.5 & 116.8 & 142.2 & 64.0 & 79.3 & 97.5 & 86.4 \\
\hline France ${ }^{e}$ & $1,590,0$ & $1,270.0$ & 152.4 & - & - & 222.9 & - & - & - \\
\hline Hong Kong & 25.9 & 18.5 & 187.5 & 211.3 & $1,427,8$ & $3,297.3$ & $2,258.3$ & 606.6 & 194.1 \\
\hline India & 69.0 & - & - & - & - & - & - & - & 125.0 \\
\hline Indonesia & 5.4 & 4.7 & 2.7 & 0.9 & 0.2 & 1.7 & 0.9 & - & - \\
\hline Iran & 10.4 & 61.0 & - & 10.2 & - & - & - & - & - \\
\hline Iraq & 50.8 & 152.4 & - & 71.6 & 182.9 & 99.3 & 25.4 & 157.5 & - \\
\hline Italy $f$ & - & - & 0.8 & - & - & - & - & - & - \\
\hline Japan & - & - & - & - & - & 171.2 & $3,990.3$ & - & 151.4 \\
\hline Kenya & - & - & - & - & - & - & 304.8 & 213.4 & 12.2 \\
\hline Korea & - & - & - & - & - & - & - & - & - \\
\hline Mauritius & - & - & 0.8 & - & 4.4 & 2.0 & 3.7 & 6.1 & - \\
\hline
\end{tabular}




\begin{tabular}{|c|c|c|c|c|c|c|c|c|c|}
\hline Morocco & 25.4 & - & - & - & - & - & - & $=$ & - \\
\hline Mozambique & - & - & - & - & - & - & - & 230.6 & 371.9 \\
\hline Netherlands & $2,855.0$ & $1,831,9$ & $3,653.8$ & $4,782.6$ & $4,964.2$ & 625.4 & 269.3 & 101.6 & 16.3 \\
\hline New Zealand & 7.1 & 6.1 & 14.8 & 33.5 & 19.3 & 4.6 & 6.9 & 4.1 & 4.1 \\
\hline Nigerias & - & - & - & - & - & 25.4 & 20.3 & - & - \\
\hline Pakistanc & $2,245.8$ & $1,677.5$ & $1,924.7$ & $2,270.8$ & $2,374.8$ & $2,566.9$ & $2,503.8$ & $4,337.3$ & $3,649.5$ \\
\hline Peru & 255.0 & 203.2 & 182.9 & 198.1 & 182.7 & 304.4 & 162.6 & 233.7 & - \\
\hline Philippines & - & - & - & - & - & - & 99.6 & - & - \\
\hline Sabah & 0.1 & - & 25.6 & 0.3 & 1.1 & 3.0 & 0.7 & 1.0 & 2.0 \\
\hline Sarawak & 15.3 & 0.1 & 0.4 & 0.5 & 2.5 & 10.6 & 0.6 & 1.0 & 25.4 \\
\hline Saudi Arabia & - & 5.1 & - & - & - & - & - & - & 25.4 \\
\hline South Africa & 81.3 & 91.4 & 70.9 & 12.2 & 10.2 & - & - & - & - \\
\hline South Yemen & 1.0 & - & - & 5.0 & - & - & 1.0 & - & - \\
\hline Sri Lanka & 3.3 & 19.6 & 19.8 & 89.9 & 51.7 & 56.1 & 52.8 & 4.1 & 28.5 \\
\hline Switzerland & 50.8 & - & - & - & - & - & - & - & - \\
\hline Tanzania & - & - & - & - & - & - & - & - & 1.0 \\
\hline Taiwan & - & - & - & - & - & - & 20.3 & 812.6 & 601.5 \\
\hline Thailand & 2.0 & 2.0 & - & - & - & - & - & - & - \\
\hline West Germany & 87,4 & 436.9 & 127.0 & 25.4 & 198.1 & 61.0 & 10.2 & 10.2 & 12.2 \\
\hline West Malaysia & 77.5 & 42.4 & - & 11.9 & 11.9 & 11.3 & 9.9 & 10.2 & 3.1 \\
\hline United Kingdom & $19,884.4$ & $15,231.8$ & $18,461.2$ & $19,197.3$ & $19,382.7$ & $15,866,0$ & $26,836.1$ & $4,570.0$ & $3,642.4$ \\
\hline $\begin{array}{l}\text { United States } \\
\text { of America }\end{array}$ & 756.2 & 659.0 & 772.6 & 539.5 & 231.8 & 372.8 & 374.1 & 320.0 & 417.6 \\
\hline Zambia, Malawi & & & & & & & & & \\
\hline \& Rhodesia & $23.8^{\mathrm{h}}$ & $27.2^{h}$ & 27.3 & 36.3 & 27.1 & 18.1 & 31.8 & - & - \\
\hline O.C. Africa & 91.4 & 102.0 & 127.1 & 255.0 & 453.1 & 25.4 & 355.6 & 22.4 & 38.6 \\
\hline O.C. Asia & - & 1,1 & 2.3 & 1.3 & 1.7 & - & - & - & - \\
\hline O.C. Middle East & - & - & - & - & - & 101.6 & 203.2 & 198.1 & 411.5 \\
\hline TOTAL & $28,321.5$ & $21,993.9$ & $26,388.5$ & $28,885.9$ & $29,711.2$ & $24,115,3$ & $37,643.1$ & $12,021.3$ & $9,997.9$ \\
\hline
\end{tabular}


TABLE 22. (cont.)

\begin{tabular}{|c|c|c|c|c|c|c|c|c|c|}
\hline $\begin{array}{l}\text { Importing } \\
\text { Country }\end{array}$ & $1966^{a}$ & $1967^{\mathrm{a}}$ & $1968^{\mathrm{a}}$ & $1969^{\mathrm{a}}$ & $1970^{\mathrm{a}}$ & $1971^{\mathrm{a}}$ & 1972 & 1973 & $1974^{b}$ \\
\hline Australia & 8.1 & 9.1 & 8.1 & 7.1 & 10.7 & 3.1 & 7.0 & - & 4.0 \\
\hline Bangladesh ${ }^{c}$ & - & - & - & - & - & - & 34.0 & 109.0 & 14.0 \\
\hline Belgiumd & - & - & - & - & 25.4 & - & - & 200.0 & - \\
\hline \multicolumn{10}{|l|}{ British Caribbean } \\
\hline Federation & - & - & 1.0 & 4.1 & 2.0 & - & - & - & - \\
\hline Brunei & 2.0 & 5.1 & 6.1 & 5.1 & 9.0 & 3.1 & 4.0 & 3.0 & 2.0 \\
\hline Burma & 123.8 & - & 243.8 & 254.0 & 104.7 & 203.2 & 102.0 & 51.0 & - \\
\hline Cambodia & - & - & - & 25.4 & - & - & - & 30.0 & - \\
\hline Canada & - & - & - & - & - & - & - & - & 89.0 \\
\hline Christmas Island & 1.0 & 1.0 & 1.0 & 1.0 & 0.7 & - & - & - & - \\
\hline \multicolumn{10}{|l|}{ Colombia and } \\
\hline Ecuador & - & - & - & - & - & - & - & - & - \\
\hline Czechoslovakia & - & - & - & - & - & - & - & - & - \\
\hline Denmark & - & 5.1 & - & - & - & - & - & - & - \\
\hline Eire & 57.9 & 76.2 & 50.8 & 61.0 & 56.9 & 50.8 & - & - & - \\
\hline France & 5.1 & - & - & - & - & - & - & - & - \\
\hline Hong Kong & 191.0 & $1,924.3$ & 624.8 & 440.0 & 90.6 & 222.5 & 1.0 & 8.0 & - \\
\hline India & - & - & 25.4 & - & - & - & - & - & - \\
\hline Indonesia & - & - & - & - & - & - & - & - & - \\
\hline Iran & - & - & - & - & - & - & - & - & - \\
\hline Iraq & - & - & - & 81.3 & - & - & 203.0 & 400.0 & - \\
\hline Italy ${ }^{f}$ & 2.0 & 10.2 & - & - & - & - & - & - & - \\
\hline Japan & 957.1 & $7,754.1$ & $13,535.2$ & $14,506.5$ & $10,731.0$ & $3,000.3$ & 100.0 & 120.0 & 100.0 \\
\hline Kenya & 45.7 & - & 20.0 & 42.7 & - & - & - & - & - \\
\hline Korea & - & - & - & - & - & - & - & - & 50.0 \\
\hline Mauritius & - & 1.0 & 20.3 & - & - & - & - & - & - \\
\hline Morocco & - & - & - & - & - & - & - & - & - \\
\hline Mozambique & 224.5 & 450.1 & 372.9 & 369.8 & 633.0 & 326.1 & 449.0 & 521.0 & 240.0 \\
\hline Netherlands & 5.1 & 360.7 & 5.1 & 5.1 & - & - & 3.0 & 50.0 & - \\
\hline
\end{tabular}




\begin{tabular}{|c|c|c|c|c|c|c|c|c|c|}
\hline New Zealand & 4.1 & 5.1 & 3.1 & 2.0 & - & 2.0 & 2.0 & 4.0 & 4.0 \\
\hline Nigeriag & - & 5.1 & - & - & - & - & - & - & - \\
\hline Pakistanc & 990.6 & $2,011.7$ & $1,658.1$ & $1,753.6$ & $2,043.5$ & $1,249.7$ & 361.0 & 897.0 & 530.0 \\
\hline Peru & - & - & - & - & - & - & - & - & - \\
\hline Philippines & - & - & - & - & - & - & - & - & - \\
\hline Sabah & 1.0 & 1.0 & 3.1 & 5.1 & 3.5 & 6.1 & 7.0 & 11.0 & 12.0 \\
\hline Sarawak & 1.0 & 1.0 & 157.5 & 75.2 & 0.5 & - & - & 1.0 & 1.0 \\
\hline Saudi Arabia & - & 35.6 & 10.2 & - & - & - & - & - & 1.0 \\
\hline South Africa & - & - & - & - & - & - & - & - & - \\
\hline South Yemen & - & - & - & - & - & - & - & - & - \\
\hline Sri Lanka & 8,1 & 96.5 & 5.1 & 22.4 & 4.8 & 15.2 & - & - & - \\
\hline Switzerland & - & - & - & - & - & - & - & - & - \\
\hline Tanzania & - & - & - & - & - & - & - & - & - \\
\hline Taiwan & - & $1,699.8$ & - & - & - & - & - & - & - \\
\hline Thailand & - & - & - & - & - & - & - & - & - \\
\hline West Germany & - & - & 7.1 & - & - & - & - & - & - \\
\hline West Malaysia & 4.1 & 3.1 & 281.4 & 58.9 & 5.8 & 3.1 & 2.0 & - & - \\
\hline United Kingdom & $2,325,6$ & $2,816.4$ & $4,153,4$ & $2,393.7$ & $1,661,2$ & 990.6 & 772.0 & 198.0 & 51.0 \\
\hline \multicolumn{10}{|l|}{ United States } \\
\hline of America & 151.4 & 274.3 & 136.1 & 70.1 & 100.4 & 70.1 & 102.0 & 127.0 & 578.0 \\
\hline \multicolumn{10}{|l|}{ Zambia, Malawi } \\
\hline \& Rhodesia & - & - & - & - & - & - & - & - & - \\
\hline O.C. Africa & 76.2 & 1.0 & - & 20.3 & - & 223.5 & 172.0 & 165.0 & 110.0 \\
\hline O.C.Asia & - & - & - & - & 0.1 & - & 1.0 & - & - \\
\hline O.C. Middle East & 269.2 & 309.9 & 501.9 & 280.4 & 325.2 & 371.9 & 331.0 & 396.0 & 180.0 \\
\hline TOTAL & $5,454.6$ & $17,857.4$ & $21,831.5$ & $20,484.8$ & $15,809.0$ & $6,741.3$ & $2,653.0$ & $3,291,0$ & $1,966,0$ \\
\hline
\end{tabular}

SOURCE:

Republic of Singapore n.d.
Notes:

- Zero exports

a Converted from long tons and rounded.

b January through September only.

c Imports of Bangladesh included with those of Pakistan prior to 1972. d Includes Luxembourg. e Includes Monaco.

f Includes San Marino.

8 Includes Cameroon.

h Excludes Malawi. 
TABLE 23. Direction of Import Trade in Sago Refuse, 1960-1974

\begin{tabular}{|c|c|c|c|c|c|c|c|c|}
\hline Country of Origin & 1960 & 1961 & 1962 & 1963 & 1964 & 1965 & 1966 & 1967 \\
\hline & \multicolumn{8}{|c|}{ To Brunei } \\
\hline Sarawak & $\ldots$ & $\cdots$ & $\cdots$ & - & 87.4 & 78.6 & 29.1 & 65.1 \\
\hline Singapore & $\cdots$ & $\ldots$ & $\ldots$ & - & - & - & - & - \\
\hline West Malaysia & $\ldots$ & $\cdots$ & $\ldots$ & - & - & - & - & - \\
\hline \multirow[t]{2}{*}{ Total } & $\ldots$ & $\ldots$ & $\ldots$ & - & 87.4 & 78.6 & 29.1 & 65.1 \\
\hline & \multicolumn{8}{|c|}{ To Singapore } \\
\hline Indonesia & $\ldots$ & $\ldots$ & 338.6 & $1,969.5$ & - & - & - & - \\
\hline Sarawak & $\ldots$ & $\ldots$ & - & - & - & 175.8 & 105.7 & 18.3 \\
\hline West Malaysia & $\ldots$ & $\ldots$ & $1,055.5$ & $1,623.4$ & $4,987.5$ & $7,255.0^{\mathrm{a}}$ & $6,730.0$ & $8,540.5$ \\
\hline \multirow[t]{2}{*}{ Total } & $\cdots$ & $\ldots$ & $1,394.1$ & $3,592.9$ & $4,987.5$ & $7,431.1$ & $6,856.0$ & $8,558.8$ \\
\hline & \multicolumn{8}{|c|}{ To West Malaysia ${ }^{b}$} \\
\hline China $^{c}$ & - & - & - & - & 2.1 & - & - & 1.4 \\
\hline Indonesia & 832.4 & $1,042.4$ & $2,085.4$ & $1,723.3$ & 7.1 & - & - & 2.0 \\
\hline Sarawak & - & - & - & - & - & 153.4 & 149.4 & - \\
\hline Singapore & - & 36.6 & 2.7 & 0.6 & 4.4 & 87.2 & 138.9 & 110.5 \\
\hline Thailand & - & - & 1.1 & 1.2 & - & - & 3.0 & 0.6 \\
\hline Vietnam & - & - & - & - & - & - & - & - \\
\hline Total & 832.4 & $1,079.0$ & $2,089.2$ & $1,725.1$ & 13.6 & 240.6 & 291.3 & 114.5 \\
\hline
\end{tabular}




\begin{tabular}{lcccccccc}
\hline Country of Origin & 1968 & 1969 & 1970 & 1971 & 1972 & 1973 & $1974^{\mathrm{d}}$ \\
\hline & To Brunei & & & & & & \\
Sarawak & 21.1 & 11.1 & 14.0 & 10.6 & 9.0 & 6.1 & 7.5 \\
Singapore & - & - & 4.0 & - & - & 7.3 & 7.1 \\
West Malaysia & - & - & 3.0 & - & - & - & - \\
$\quad$ Total & 21.1 & 11.1 & 21.0 & 10.6 & 9.0 & 13.4 & 14.6 \\
& To Singapore & & & & & & \\
Indonesia & - & - & - & - & - & - & - \\
Sarawak & - & - & - & - & 20.0 & - & - \\
West Malaysia & $6,963.7$ & $6,500.4$ & $5,662.4$ & $4,894.1$ & $5,108.0$ & $4,519.0$ & $3,960.0^{\mathrm{a}}$ \\
$\quad$ Total & $6,963.7$ & $6,500.4$ & $5,662.4$ & $4,894.1$ & $5,128.0$ & $4,519.0$ & $3,960.0^{\mathrm{a}}$ \\
& To West Malaysia & & & & & \\
Chinac & - & 2.1 & 0.4 & 0.7 & - & - & - \\
Indonesia & - & - & 10.0 & 15.2 & 12.2 & - & - \\
Sarawak & - & - & - & - & - & - & - \\
Singapore & 106.3 & 37.6 & 25.6 & 18.0 & 9.5 & - & - \\
Thailand & 4.6 & - & 0.2 & - & - & - & - \\
Vietnam & 3.2 & - & - & - & - & - & - \\
$\quad$ Total & 114.1 & 39.7 & 36.2 & 33.9 & 21.7 & - & - \\
\hline
\end{tabular}

SOURCES:

Office of State Secretary, Brunei, personal communication; Republic of Singapore n.d.; and West Malaysia, Office of Chief Statistician, Department of Statistics, personal communication.

Notes:

In M.T., converted from long tons and rounded; . . . no data available; - zero imports.

a January through October only.

bPreliminary data for 1974.

'People's Republic of China.

d January through July only. 
TABLE 24. Direction of Export Trade in Sago Refuse, 1960-1974

\begin{tabular}{|c|c|c|c|c|c|c|c|c|}
\hline Importing Country & 1960 & 1961 & 1962 & 1963 & 1964 & 1965 & 1966 & 1967 \\
\hline & \multicolumn{8}{|c|}{ From Sarawak } \\
\hline Brunei & $\ldots$ & $\ldots$ & ... & $\cdots$ & $\ldots$ & $\ldots$ & 52.2 & 52.3 \\
\hline Sabah & $\ldots$ & $\ldots$ & $\ldots$ & $\ldots$ & $\ldots$ & $\ldots$ & 1.3 & - \\
\hline Singapore & $\ldots$ & ... & $\ldots$ & $\ldots$ & $\ldots$ & $\ldots$ & 70.1 & - \\
\hline \multirow[t]{2}{*}{ Total } & $\ldots$ & $\ldots$ & $\ldots$ & $\ldots$ & $\ldots$ & $\ldots$ & 123.6 & 52.3 \\
\hline & \multicolumn{8}{|c|}{ From West Malaysia $^{a}$} \\
\hline Brunei & - & - & - & - & - & - & - & - \\
\hline Sabah & - & - & - & - & - & - & - & - \\
\hline Sarawak & - & - & - & - & - & - & - & - \\
\hline Singapore & 175.1 & 346.0 & $1,055.6$ & $1,623.4$ & $1,623.4$ & $7,255.5$ & $6,750.0$ & $8,540.4$ \\
\hline Thailand & - & - & - & - & - & - & - & - \\
\hline Total & 175.1 & 346.0 & $1,055.6$ & $1,623,4$ & $1,623.4$ & $7,255.5$ & $6,750.0$ & $8,540.4$ \\
\hline
\end{tabular}




\begin{tabular}{|c|c|c|c|c|c|c|c|}
\hline Importing Country & 1968 & 1969 & 1970 & 1971 & 1972 & 1973 & 1974 \\
\hline \multicolumn{8}{|c|}{ From Sarawak } \\
\hline Brunei & 20.5 & 18.6 & 43.0 & 6.2 & 11.3 & 5.0 & $\ldots$ \\
\hline Sabah & - & - & - & - & - & - & $\ldots$ \\
\hline Singapore & - & - & - & - & - & - & $\ldots$ \\
\hline Total & 20.5 & 18.6 & 43.0 & 6.2 & 11.3 & 5.0 & $\ldots$ \\
\hline \multicolumn{8}{|c|}{ From West Malaysia ${ }^{a}$} \\
\hline Brunei & - & - & - & - & 11.3 & - & - \\
\hline Sabah & - & - & 0.7 & - & - & - & - \\
\hline Sarawak & & - & - & - & - & - & - \\
\hline Singapore & $7,361,4$ & $6,008.4$ & $5,183.4$ & $5,333.6$ & $5,096.6$ & $4,291.6$ & $4,434.8$ \\
\hline Thailand & - & - & - & - & - & - & - \\
\hline Total & $7,361,4$ & $6,008.4$ & $5,184.1$ & $5,333.6$ & $5,107,9$ & $4,291.6$ & $4,434.8$ \\
\hline
\end{tabular}

SOURCES:

State of Sarawak, Office of Director of Department of Agriculture, personal communication; and West Malaysia, Office of Chief Statistician, Department of Statistics, personal communication.

Notes:

In M,T., converted from long tons and rounded; . . . no data available; - zero exports.

aData for 1972 are preliminary. 
TABle 25. Sarawak: Exports of Sago Pith, 1870-1924

\begin{tabular}{|c|c|c|c|c|c|}
\hline Year & M.T.* & Year & M.T.* & Year & M.T.* \\
\hline $1870^{a}$ & $\ldots$ & $1889^{a}$ & 762 & $1907^{b}$ & $\cdots$ \\
\hline $1871^{\mathrm{a}}$ & $\ldots$ & $1890^{a}$ & 969 & $1908^{b}$ & 1,302 \\
\hline $1872^{a}$ & $\ldots$ & $1891^{\mathrm{a}}$ & 5,304 & $1909^{b}$ & 2,056 \\
\hline $1873^{a}$ & $\ldots$ & 1892 & $\ldots$ & $1910^{b}$ & 1,158 \\
\hline $1874^{a}$ & $\ldots$ & $1893^{a}$ & 8,251 & $1911^{\mathrm{b}}$ & 1,119 \\
\hline $1875^{a}$ & $\ldots$ & $1894^{\mathrm{a}}$ & 4,358 & $1912^{b}$ & 1,234 \\
\hline 1876 & 422 & 1895 & $\ldots$ & $1913^{b}$ & 326 \\
\hline $1877^{a}$ & $\ldots$ & 1896 & $\ldots$ & $1914^{b}$ & 433 \\
\hline $1878^{a}$ & $\ldots$ & 1897 & $\ldots$ & $1915^{b}$ & 1,180 \\
\hline $1879^{a}$ & $\ldots$ & 1898 & $\ldots$ & $1916^{b}$ & 554 \\
\hline $1880^{a}$ & $\ldots$ & 1899 & $\ldots$ & $1917^{b}$ & 352 \\
\hline $1881^{\text {a }}$ & 903 & 1900 & $\ldots$ & $1918^{b}$ & 404 \\
\hline $1882^{a}$ & 1,075 & 1901 & $\ldots$ & $1919^{b}$ & 1,229 \\
\hline $1883^{a}$ & 873 & $1902^{a}$ & 6,426 & $1920^{\mathrm{b}}$ & 997 \\
\hline $1884^{a}$ & 272 & $1903^{a}$ & 3,966 & $1921^{\circ}$ & 304 \\
\hline $1885^{a}$ & 1,240 & $1904^{b}$ & 3,833 & $1922^{b}$ & 238 \\
\hline 1886 & $\ldots$ & $1905^{b}$ & 1,135 & $1923^{b}$ & 68 \\
\hline $1887^{a}$ & 649 & $1906^{b}$ & 1,960 & $1924^{b}$ & 21 \\
\hline $1888^{\mathrm{a}}$ & 152 & & & & \\
\hline
\end{tabular}

SOURCES:

a Sarawak Gazette, 2-28-1871:3; 2-15-1872:4; 2-17-1873:5; 3-2-1874:3; 3-16-1874:4; $6-24-1876: 5 ; 8-25-1877: 67 ; 6-24-1878: 48 ; 5-23-1879: 36 ; 3-31-1880: 19 ; 4-1-1881: 37-8$; $5-1-1882: 33-4 ; 4-2-1883: 32-3 ; 4-1-1884: 28-9 ; 5-1-1885: 51-2 ; 4-1-1886: 67-8 ; 5-1-$ $1888: 63-4 ; \quad 6-1-1889: 90-1 ; \quad 5-1-1890: 70-1 ; \quad 5-1-1891: 79-80 ; \quad 7-1-1892: 133-4 ; \quad 8-1-$ 1894:133-4; 6-1-1895:113-4; 5-2-1903:100.

b Sarawak, Annual Report of the Department of Trade and Customs (relevant years). Notes:

... No data available.

- Converted from tampins $(1$ tampin = approx. 0.09072 M.T. $)$ and rounded. 
TABLE 26. Direction of Import Trade in Sago Pith, 1960-1974

\begin{tabular}{|c|c|c|c|c|c|}
\hline Country of Origin & 1960 & 1961 & 1962 & 1963 & 1964 \\
\hline & \multicolumn{5}{|c|}{ To Brunei ${ }^{a}$} \\
\hline Sarawak & $\ldots$ & $\ldots$ & $\ldots$ & - & 12.2 \\
\hline Singapore & $\ldots$ & $\cdots$ & $\ldots$ & - & - \\
\hline Thailand & $\ldots$ & $\ldots$ & $\ldots$ & - & - \\
\hline Total & $\ldots$ & $\ldots$ & $\ldots$ & - & 12.2 \\
\hline
\end{tabular}

To Sarawak

Brunei

Sabah

Thailand

Total

Indonesia

Sarawak

West Malaysia

Total

To Singapore ${ }^{b}$

China $^{\mathrm{e}}$

India

Indonesia

Singapore

Thailand

Total

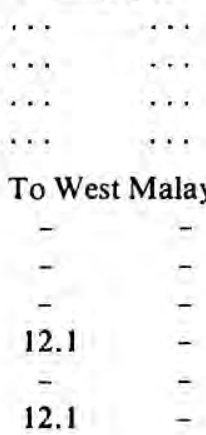

$\begin{array}{lll}13,586.3 & 9,933.1 & -\end{array}$

$\begin{array}{llll}364.3 & 783.9 & 918.5\end{array}$

$\begin{array}{llll}13,950.6 & 10,717.0 & 918.5\end{array}$

To West Malaysia ${ }^{d}$

12.1 
TABLE 26. (cont.)

\begin{tabular}{|c|c|c|c|c|}
\hline Country of Origin & 1965 & 1966 & 1967 & 1968 \\
\hline & \multicolumn{4}{|c|}{ To Brunei ${ }^{a}$} \\
\hline Sarawak & 6.4 & 21.1 & 32.7 & 23.4 \\
\hline Singapore & - & - & - & 0.1 \\
\hline Thailand & - & - & - & - \\
\hline \multirow[t]{2}{*}{ Total } & 6.4 & 21.1 & 32.7 & 23.5 \\
\hline & \multicolumn{4}{|c|}{ To Sarawak } \\
\hline Brunei & $\ldots$ & 4.2 & 6.6 & 1.2 \\
\hline Sabah & $\ldots$ & - & - & 3.1 \\
\hline Thailand & $\ldots$ & - & - & - \\
\hline \multirow[t]{2}{*}{ Total } & $\cdots$ & 4.2 & 6.6 & 4.3 \\
\hline & \multicolumn{4}{|c|}{ To Singapore $^{b}$} \\
\hline Indonesia & - & - & - & - \\
\hline Sarawak & - & $15.1^{\mathrm{C}}$ & - & - \\
\hline West Malaysia & 47.8 & - & 5.1 & - \\
\hline \multirow[t]{2}{*}{ Total } & 47.8 & 15.1 & 5.1 & - \\
\hline & \multicolumn{4}{|c|}{ To West Malaysia $^{\mathrm{d}}$} \\
\hline China $^{e}$ & - & - & $\ldots$ & $\ldots$ \\
\hline India & - & - & $\ldots$ & $\ldots$ \\
\hline Indonesia & - & - & $\ldots$ & $\ldots$ \\
\hline Singapore & - & - & $\ldots$ & $\ldots$ \\
\hline Thailand & - & - & $\ldots$ & $\ldots$ \\
\hline Total & - & - & $\ldots$ & $\ldots$ \\
\hline
\end{tabular}


TABLE 26. (cont.)

\begin{tabular}{|c|c|c|c|c|c|}
\hline 1969 & 1970 & 1971 & 1972 & 1973 & 1974 \\
\hline - & - & - & - & - & - \\
\hline - & 0.1 & 0.1 & 0.2 & - & - \\
\hline- & 0.1 & 0.1 & 0.1 & - & - \\
\hline - & 0.2 & 0.2 & 0.3 & - & - \\
\hline - & - & - & - & - & $\ldots$ \\
\hline - & - & - & - & - & $\ldots$ \\
\hline- & - & - & - & 1.1 & $\ldots$ \\
\hline - & - & - & - & 1.1 & $\ldots$ \\
\hline - & - & - & - & - & - \\
\hline - & - & - & - & - & - \\
\hline - & - & - & - & - & 73.0 \\
\hline - & - & - & - & - & 73.0 \\
\hline & & & & & \\
\hline - & - & 0.6 & - & - & - \\
\hline- & - & - & 0.1 & - & - \\
\hline 3.8 & - & - & - & - & - \\
\hline- & - & - & - & - & - \\
\hline- & 1.2 & - & - & - & - \\
\hline 3.8 & 1.2 & 0.6 & 0.1 & - & - \\
\hline
\end{tabular}

\section{SOURCES:}

Office of State Secretary, Brunei, personal communication; State of Sarawak, Office of Director of Department of Agriculture, personal communication; Republic of Singapore n.d; ; and West Malaysia, Office of the Chief Statistician, Department of Statistics, personal communication.

NoTES:

In M.T., converted from long tons and rounded; . . . no data available; - zero imports.

a 1974 data January through July only.

b 1974 data January through October only.

c Data from State of Sarawak.

¿Data for 1974 are preliminary.

e People's Republic. 
TABLE 27. Direction of Export Trade in Sago Pith, 1960-1974

\begin{tabular}{|c|c|c|c|c|c|c|c|}
\hline $\begin{array}{l}\text { Importing } \\
\text { Country }\end{array}$ & 1960 & 1961 & 1962 & 1963 & 1964 & 1965 & 1966 \\
\hline & \multicolumn{7}{|c|}{ From Brunei ${ }^{a}$} \\
\hline Sabah & $\ldots$ & $\ldots$ & $\ldots$ & - & - & - & 0.3 \\
\hline Sarawak & $\ldots$ & $\ldots$ & $\ldots$ & - & 7.1 & 3.1 & 4.7 \\
\hline \multirow[t]{2}{*}{ Total } & $\ldots$ & $\cdots$ & $\ldots$ & - & 7.1 & 3.1 & 5.0 \\
\hline & \multicolumn{7}{|c|}{ From Sabah } \\
\hline Sarawak & $\ldots$ & $\ldots$ & - & - & - & - & - \\
\hline \multirow[t]{2}{*}{ Total } & $\ldots$ & $\cdots$ & - & - & - & - & - \\
\hline & \multicolumn{7}{|c|}{ From Sarawak } \\
\hline Brunei & $\ldots$ & $\ldots$ & $\ldots$ & $\ldots$ & $\ldots$ & $\ldots$ & 27.8 \\
\hline Sabah & $\ldots$ & $\ldots$ & $\ldots$ & $\ldots$ & $\ldots$ & $\ldots$ & 15.1 \\
\hline \multirow[t]{2}{*}{ Total } & ... & $\cdots$ & $\ldots$ & $\ldots$ & $\cdots$ & $\cdots$ & 42.9 \\
\hline & \multicolumn{7}{|c|}{ From West Malaysia ${ }^{b}$} \\
\hline Singapore & 874.7 & 442.1 & - & 783.9 & 918.4 & 47.3 & $\ldots$ \\
\hline Total & 874.7 & 442.1 & - & 783.9 & 918.4 & 47.3 & $\ldots$ \\
\hline
\end{tabular}


TABLE 27. (cont.)

\begin{tabular}{|c|c|c|c|c|c|c|c|}
\hline 1967 & 1968 & 1969 & 1970 & 1971 & 1972 & 1973 & 1974 \\
\hline - & - & - & - & - & - & 0.6 & - \\
\hline 5.5 & 1.5 & 13.8 & 18.8 & 18.0 & 23.7 & 20.3 & 8.5 \\
\hline 5.5 & 1.5 & 13.8 & 18.8 & 18.0 & 23.7 & 20.9 & 8.5 \\
\hline- & - & - & - & 1.0 & - & - & - \\
\hline- & - & - & - & 1.0 & - & - & - \\
\hline 34.7 & 25.4 & - & - & - & - & 2.9 & $\ldots$ \\
\hline- & - & - & - & - & - & - & $\ldots$ \\
\hline 34.7 & 25.4 & - & - & - & - & 2.9 & $\ldots$ \\
\hline 5.1 & - & - & - & - & 0.4 & - & 42.7 \\
\hline 5.1 & - & - & - & - & 0.4 & - & 42.7 \\
\hline
\end{tabular}

SOURCES:

Office of State Secretary, Brunei, personal communication; State of Sabah, Department of Statistics, Statistics of External Trade, Sabah; State of Sarawak, Office of Director of Department of Agriculture, personal communication; and West Malaysia, Office of Chief Statistician, Department of Statistics, personal communication.

Notes:

In M.T., converted from long tons and rounded; . . . no data available; - zero exports.

a 1974 data are for January through July only.

bData for 1974 are preliminary. 
TABle 28. Singapore: Direction of Export Trade in Pearl Sago, 1957-1974 (metric tons)

\begin{tabular}{|c|c|c|c|c|c|c|c|c|}
\hline Importing Nation & $1957^{\mathrm{a}}$ & $1958^{a}$ & $1959^{\mathrm{a}}$ & $1960^{\mathrm{a}}$ & $1961^{\text {a }}$ & $1962^{b}$ & $1963^{b}$ & $1964^{b}$ \\
\hline Australia & 883.3 & 356.8 & 433.0 & 564.8 & 365.8 & 506.4 & 475.5 & 114.7 \\
\hline Bahrein & 9.7 & 35.0 & 55.9 & 26.9 & - & 7.4 & 5.1 & - \\
\hline Bangladesh ${ }^{\mathrm{d}}$ & - & - & - & - & - & - & - & - \\
\hline Belgium & - & 2.0 & - & - & - & - & - & - \\
\hline \multicolumn{9}{|l|}{ British Caribbean } \\
\hline Federation & - & - & 64.1 & 61.1 & 50.9 & 42.0 & 60.9 & 29.3 \\
\hline Brunei & 3.2 & 3.7 & 2.5 & 3.0 & 2.1 & 2.7 & 2.9 & 3.7 \\
\hline Burma & 4.1 & - & 6.1 & 7.1 & 1.1 & 5.8 & - & - \\
\hline Cambodia & - & 13.0 & - & 19.9 & - & - & - & - \\
\hline Canada & - & 6.7 & - & - & 3.0 & 1.7 & 2.1 & 2.1 \\
\hline Chile & - & - & - & - & 0.9 & - & - & - \\
\hline Christmas Island & - & - & - & - & - & - & - & - \\
\hline Denmark & 15.2 & 12.2 & 12.7 & 15.2 & 13.7 & 15.2 & 8.1 & 5.1 \\
\hline Dominican Republic & $=$ & - & - & - & - & - & - & 0.5 \\
\hline Ecuador & - & - & - & - & - & - & - & - \\
\hline Eire & 148.3 & 190.0 & 141.2 & 139.2 & 160.5 & 145.3 & 148.0 & 77.7 \\
\hline Fiji & - & - & - & - & - & 7.6 & 8.9 & 9.9 \\
\hline France $^{c}$ & - & - & - & - & - & - & - & - \\
\hline Hong Kong & - & - & - & - & - & 2.9 & - & - \\
\hline Iceland & 40.1 & 74.5 & 34.5 & 12.7 & 12.7 & - & - & - \\
\hline India & 8.1 & - & - & - & - & 0.5 & - & - \\
\hline Indonesia & 0.1 & 0.1 & 0.3 & 0.2 & 0.5 & 0.2 & - & - \\
\hline Italy & - & - & - & 0.5 & - & - & 8.5 & - \\
\hline Kenya & - & - & - & - & - & 18.8 & 15.1 & 18.3 \\
\hline Kuwait & - & - & - & - & - & - & - & - \\
\hline Macaof & 11.7 & 16.8 & 14.7 & 15.2 & 15.2 & - & - & - \\
\hline Mauritius & 19.5 & 21.1 & 22.5 & 28.9 & 23.8 & 22.5 & 29.0 & 26.2 \\
\hline Mexico & $=$ & - & - & - & - & - & - & - \\
\hline Mozambique & 7.8 & 1,9 & 4.3 & 1.8 & 1.5 & - & - & 1.9 \\
\hline Netherlands & 31.7 & 37.2 & - & 25.4 & 25.4 & - & - & - \\
\hline New Zealand & 12.4 & 3.1 & 4.0 & 2.0 & 8.0 & 2.7 & 1,9 & - \\
\hline Nigeria & - & - & - & - & - & - & - & 2.0 \\
\hline Pakistan ${ }^{d}$ & 24.5 & 157.0 & 52.2 & 11.7 & 13.9 & 0.4 & - & 9.3 \\
\hline Peru & 4.1 & - & - & - & - & - & - & - \\
\hline Sabah & 2.3 & 24.0 & 1.4 & 1.2 & 1.0 & 0.9 & 1.4 & 1.1 \\
\hline Sarawak & 25.5 & 24.5 & 15.1 & 17.8 & 20.8 & 15.5 & 15.1 & 14.6 \\
\hline Saudi Arabia & 20.8 & 22.4 & 9.1 & 12.2 & 25.9 & 27.2 & 23.4 & 27.4 \\
\hline South Africa & 305.2 & 181.2 & 223.0 & 121.3 & 79.7 & 98.1 & 46.1 & 8.0 \\
\hline South Vietnam & - & - & - & - & - & - & - & - \\
\hline South Yemen & 1.0 & 0.4 & 0.6 & 0.8 & 0.4 & 0.7 & 1.0 & 0.8 \\
\hline Spain & - & - & - & - & - & - & - & - \\
\hline Sri Lanka & 1.3 & 7.6 & 0.6 & 0.7 & 0.9 & 10.7 & 2.5 & 0.8 \\
\hline Surinam8 & - & - & - & 0.4 & - & - & - & - \\
\hline Switzerland & 40.6 & 50.8 & 50.8 & 25.4 & 76,2 & 50.8 & 50.8 & 25.4 \\
\hline
\end{tabular}


TABLE 28. (cont.)

\begin{tabular}{|c|c|c|c|c|c|c|c|c|c|}
\hline $1965^{b}$ & $1966^{\mathrm{b}}$ & $1967^{b}$ & $1968^{b}$ & $1969^{\mathrm{b}}$ & $1970^{6}$ & $1971^{\mathrm{b}}$ & 1972 & 1973 & $1974^{c}$ \\
\hline 96.3 & 53.3 & 74.4 & 10.7 & 6.1 & 3.1 & 3.1 & - & - & - \\
\hline 3.1 & - & - & - & 2.0 & 1.0 & - & 3.0 & 7.0 & 18.1 \\
\hline- & - & - & - & - & - & - & - & 23.3 & 33.2 \\
\hline- & - & - & - & - & - & - & - & - & - \\
\hline 62.5 & 53.4 & 39.3 & 34.2 & 61.5 & 19.1 & 46.6 & 20.6 & 44.7 & 38.1 \\
\hline 6.0 & 5.4 & 4.8 & 5.4 & 2.8 & 2.4 & 3.8 & 4.0 & 5.0 & 4.9 \\
\hline- & - & - & - & - & - & - & - & - & - \\
\hline - & - & - & - & - & - & - & 255.0 & 160.0 & 50.0 \\
\hline - & - & - & - & - & 0.2 & - & 0.2 & - & 0.4 \\
\hline - & - & - & - & - & - & - & - & - & - \\
\hline 0.1 & - & - & 0.1 & 0.2 & 0.2 & 0.3 & 0.3 & 0.1 & - \\
\hline 7.6 & 3.1 & 6.1 & - & - & - & - & - & - & - \\
\hline- & - & - & - & - & - & - & - & - & - \\
\hline- & - & - & - & 2.0 & 2.0 & 9.1 & 2.0 & - & 2.0 \\
\hline 112.8 & 103.6 & 74.7 & 64.5 & 82.8 & 29.0 & 17.8 & 56.8 & 24.4 & 36.6 \\
\hline 8.1 & 9.5 & 5.8 & 10.9 & 9.1 & 10.1 & 10.1 & 19.0 & 10.0 & 8.3 \\
\hline- & - & - & - & - & 0.1 & 0.3 & 0.1 & 1.0 & 0.7 \\
\hline - & - & - & - & - & - & - & - & - & - \\
\hline - & - & - & - & - & - & - & - & - & - \\
\hline - & - & - & - & - & - & - & - & - & - \\
\hline - & - & - & - & - & - & - & - & - & - \\
\hline - & - & - & - & - & - & - & - & - & - \\
\hline 12.0 & 19.7 & 14.9 & 18.1 & 14.4 & 14.3 & 13.4 & 13.2 & 6.6 & 8.5 \\
\hline- & - & - & 0.1 & - & 2.0 & - & - & - & - \\
\hline- & - & - & - & - & - & - & - & - & - \\
\hline 21.5 & 25.1 & 29.4 & 20.4 & 31.7 & 52.0 & 43.2 & 36.7 & 30.7 & 30.4 \\
\hline- & - & - & - & - & 0.3 & - & - & - & - \\
\hline 5.1 & 4.6 & 3.1 & 2.6 & 2.7 & 2.7 & 4.2 & 4.3 & 3.4 & 6.9 \\
\hline 0.5 & 10.2 & 0.1 & - & 0.1 & - & - & - & - & - \\
\hline- & 11.4 & - & - & - & - & - & - & - & - \\
\hline 0.4 & - & - & - & - & - & - & - & - & - \\
\hline 3.3 & 41.7 & - & 7.2 & - & - & - & 4.5 & 18.0 & 27.7 \\
\hline- & 4.1 & - & - & - & - & - & - & - & - \\
\hline 1.3 & 2.7 & 2.7 & 2.7 & 3.3 & 3.3 & 4.2 & 5.5 & 8.8 & 19.0 \\
\hline 18.2 & 18.9 & 20.7 & 23.9 & 21.5 & 15.4 & 14.2 & 16.7 & 21.7 & 23.4 \\
\hline 29.5 & 5.1 & 22.4 & 17.3 & 6.1 & 3.1 & 11.4 & 10,9 & 14.6 & 69.3 \\
\hline 22.2 & 3.2 & 9.4 & 1.0 & - & - & - & - & - & - \\
\hline- & - & - & - & - & - & 0.2 & - & - & - \\
\hline 1.0 & 3.0 & 0.3 & 0.3 & 1.2 & 1.2 & - & 3.0 & - & - \\
\hline$=$ & 11.7 & - & - & 2.5 & - & - & - & - & - \\
\hline 2.3 & 5.6 & 13.7 & - & 8.1 & 5.7 & 6.1 & 0.1 & - & - \\
\hline- & - & - & - & - & - & - & - & - & - \\
\hline 25.4 & 76.2 & 50.8 & 25.4 & 25.4 & - & - & - & - & - \\
\hline
\end{tabular}


TABLE 28. (cont.)

\begin{tabular}{|c|c|c|c|c|c|c|c|c|}
\hline Importing Nation & $1957^{a}$ & $1958^{a}$ & $1959^{a}$ & $1960^{\mathrm{a}}$ & $1961^{\mathrm{a}}$ & $1962^{b}$ & $1963^{b}$ & $1964^{\mathrm{b}}$ \\
\hline Taiwan & - & - & - & - & - & - & - & - \\
\hline Tanzania $^{h}$ & 0.1 & - & 0.4 & 0.6 & 0.4 & 1.9 & 2.8 & 1.7 \\
\hline Uganda & 0.1 & - & - & - & - & - & - & - \\
\hline \multicolumn{9}{|l|}{ United Arab } \\
\hline Emirates & - & - & - & - & - & - & - & - \\
\hline United Kingdom & $1,850.1$ & $1,672,8$ & $1,477,3$ & $1,669.3$ & $1,474.2$ & $1,756.2$ & $1,567.7$ & $1,691.5$ \\
\hline \multicolumn{9}{|l|}{ United States } \\
\hline of America & - & - & - & - & - & - & - & - \\
\hline West Germany & 10.2 & 2.5 & 91.4 & 106.7 & 88.0 & 66.0 & 10.2 & - \\
\hline West Malaysia & 1.7 & 4.0 & 1.9 & 0.4 & - & 4.5 & 1.4 & 1.2 \\
\hline Western Samoa & - & - & - & $=$ & - & - & - & - \\
\hline \multicolumn{9}{|l|}{ Zambia, Malawi } \\
\hline \& Rhodesia & 12.6 & 9.6 & $6.2^{i}$ & $5.8^{i}$ & $4.1^{i}$ & $7.3^{i}$ & $0.1^{i}$ & - \\
\hline O.C. Africa & 23.8 & 21.1 & 15.7 & 18.6 & 14.9 & 2.1 & 3.5 & 1.3 \\
\hline \multicolumn{9}{|l|}{ O.C.C.\& } \\
\hline S. America & 104.2 & 101.2 & 19.1 & 58.3 & 60.7 & 23.8 & 17.9 & 13.6 \\
\hline O.C. Asia & 93.8 & 122.2 & 114.3 & 87.7 & 35.1 & - & 1.0 & - \\
\hline O.C. W, Europe & - & - & - & - & - & 14.6 & 8.5 & 8.5 \\
\hline O.C. Middle East & - & - & - & - & - & 48.1 & 53.3 & - \\
\hline O.C. Oceania & 4.1 & 5.3 & 6.9 & 5.2 & 5.9 & - & - & - \\
\hline Total & $3,721,2$ & $3,180,7$ & $2,881.8$ & $3,068.0$ & $2,587.2$ & $2,910.5$ & $2,572.7$ & $2,096.6$ \\
\hline
\end{tabular}


TABLE 28. (cont.)

\begin{tabular}{|c|c|c|c|c|c|c|c|c|c|}
\hline $1965^{b}$ & $1966^{b}$ & $1967^{b}$ & $1968^{b}$ & $1969^{b}$ & $1970^{\mathrm{b}}$ & $1971^{b}$ & 1972 & 1973 & $1974^{\circ}$ \\
\hline- & - & - & - & - & - & - & - & - & 10.0 \\
\hline 2.1 & 2.1 & 2.0 & 2.1 & 1.7 & 3.1 & 2.0 & 4,1 & 5.3 & - \\
\hline- & - & - & - & - & 0.7 & 2.0 & 1.6 & - & - \\
\hline 5,6 & - & - & 1.0 & - & - & - & - & 1.0 & - \\
\hline $1,403.3$ & $1,363.1$ & $1,425.3$ & $1,47 I .8$ & $1,199.4$ & 732.9 & 784.5 & 625.6 & 484.7 & 423.9 \\
\hline - & - & - & 0.1 & - & - & 0.1 & 0.2 & 0.1 & - \\
\hline- & 2.5 & 1.0 & 1.0 & 2.0 & - & - & - & - & - \\
\hline 8.5 & 18.3 & 12.8 & 1.8 & 1.2 & 1.5 & 0.9 & 3.1 & 2.4 & 10.8 \\
\hline- & - & - & 0.3 & - & - & - & - & - & - \\
\hline- & - & - & 1.7 & - & $0.2^{\mathrm{i}}$ & 0.9 & - & - & - \\
\hline 1.6 & 1.6 & 2.2 & 2.0 & 5.3 & 6.9 & 10.5 & 8.2 & 20.4 & 7.3 \\
\hline 2.6 & 11.0 & 4.5 & 4.1 & 10.5 & 2.0 & 1.0 & 9.6 & 3.6 & 21.9 \\
\hline- & - & - & - & - & - & 8.4 & 5.1 & 6.6 & 2.5 \\
\hline 8.5 & - & - & - & - & - & - & 0.5 & - & - \\
\hline 1.5 & 5.5 & 0.9 & 1.7 & 2.6 & 1.0 & 0.6 & 1.4 & 1.2 & 3.5 \\
\hline- & - & - & - & - & - & - & - & - & - \\
\hline $1,872.9$ & $1,875.6$ & $1,821.3$ & $1,732.4$ & $1,506.2$ & 915.5 & 998.9 & $1,115.3$ & 904.6 & 857.4 \\
\hline
\end{tabular}

\section{SOURCES:}

Republic of Singapore n.d.

Notes:

- Zero exports.

a Converted from long tons and rounded.

b Converted from cwt. and rounded.

c January through Septembet only.

d Imports of Bangladesh included with those of Pakistan prior to 1972.

e Includes data for Reunion.

f Includes data for former Portuguese Timor.

8 Includes data for French Guiana.

h Data for Tanganyika and Zanzibar and Pemba published separately prior to 1964 have been combined.

i Zambia only. 
TABle 29. Direction of Export Trade in Pearl Sago, 19601974 (metric tons)

\begin{tabular}{|c|c|c|c|c|c|c|c|}
\hline $\begin{array}{l}\text { Importing } \\
\text { Country }\end{array}$ & 1960 & 1961 & 1962 & 1963 & 1964 & 1965 & 1966 \\
\hline & \multicolumn{7}{|c|}{ From Sarawak ${ }^{a}$} \\
\hline Brunei & $\ldots$ & $\ldots$ & - & - & - & 0.1 & 0.1 \\
\hline Indonesia & $\ldots$ & $\ldots$ & - & 0.2 & - & - & - \\
\hline Singapore & $\cdots$ & $\ldots$ & - & - & - & - & - \\
\hline \multicolumn{8}{|l|}{ West } \\
\hline Malaysia & $\ldots$ & $\ldots$ & - & - & - & - & - \\
\hline Total & $\cdots$ & $\cdots$ & - & 0.2 & - & 0.1 & 0.1 \\
\hline \multicolumn{8}{|c|}{ From West Malaysia ${ }^{b}$} \\
\hline Australia & - & - & - & - & - & - & - \\
\hline Bahrein & - & - & - & - & - & - & - \\
\hline Bangladesh $^{c}$ & - & - & - & - & - & - & - \\
\hline Belgium & - & - & - & - & - & - & - \\
\hline Brunei & - & - & - & - & - & - & - \\
\hline Burma & 1.2 & - & - & - & 50.8 & 436.9 & - \\
\hline Indonesia & - & - & - & - & - & - & - \\
\hline Kuwait & - & - & - & - & - & - & - \\
\hline Pakistan ${ }^{c}$ & - & - & 1.5 & - & - & 2.7 & 25.4 \\
\hline Sabah & - & - & - & - & - & - & - \\
\hline Saudi Arabia & - & - & - & - & - & - & - \\
\hline Singapore & - & 20.0 & 0.3 & 3.2 & 9.9 & - & 10.2 \\
\hline South Africa & - & - & - & - & - & - & - \\
\hline South Yemen & - & - & - & - & - & 0.1 & - \\
\hline Spain & - & - & 0.3 & - & - & - & - \\
\hline Sri Lanka & - & - & - & - & - & - & - \\
\hline Thailand & - & - & - & - & - & - & - \\
\hline \multicolumn{8}{|l|}{ United } \\
\hline Kingdom & - & - & - & - & - & - & - \\
\hline Others & - & - & - & - & - & - & - \\
\hline Total & 1.2 & 20.0 & 2.1 & 3.2 & 60.7 & 439.7 & 35.6 \\
\hline
\end{tabular}


TABLE 29. (cont.)

\begin{tabular}{cccccccc}
1967 & 1968 & 1969 & 1970 & 1971 & 1972 & 1973 & 1974 \\
\hline & & & & & & & \\
- & - & 0.6 & 0.7 & 0.1 & 0.3 & 0.3 & $\ldots$ \\
- & - & - & - & - & - & - & $\ldots$ \\
- & - & - & - & - & - & - & $\ldots$ \\
- & - & - & - & 0.1 & - & - & $\ldots$ \\
- & - & 0.6 & 0.7 & 0.2 & 0.3 & 0.3 & $\ldots$ \\
& & & & & & & \\
- & - & - & 136.9 & 3.6 & 3.1 & 5.1 & 0.2 \\
25.4 & - & 93.8 & - & - & - & 40.6 & - \\
- & - & - & - & - & - & 401.5 & 509.7 \\
- & - & - & - & - & - & - & 15.2 \\
- & - & - & - & - & 0.3 & - & - \\
- & 626.9 & - & - & - & - & 5.3 & 4.5 \\
- & - & - & - & - & - & - & - \\
- & - & 1.0 & - & - & - & - & - \\
- & - & 791.7 & 540.5 & 53.3 & 17.3 & - & 70.7 \\
- & - & - & - & - & - & - & 2.0 \\
- & - & 25.4 & - & - & - & - & - \\
25.3 & 33.5 & 50.1 & 183.6 & 222.1 & 617.2 & 426.2 & 562.4 \\
22.9 & - & - & 0.1 & - & - & - & - \\
- & - & - & - & - & - & - & - \\
- & - & - & - & - & - & - & - \\
36.6 & 172.9 & 303.6 & 9.7 & - & 140.8 & - & - \\
- & - & - & - & 16.9 & - & 1.3 & - \\
& & & & & & & \\
- & - & 1.2 & 5.1 & 265.2 & 95.4 & 47.8 & 226.2 \\
- & - & 4.6 & 3.6 & - & - & - & - \\
110.2 & 833.3 & $1,271.4$ & 879.5 & 561.1 & 874.1 & 927.8 & $1,390.9$ \\
\hline & & & & & & &
\end{tabular}

SOURCES:

State of Sarawak, Office of Senior Statistician, Department of Statistics, personal communication; and West Malaysia, Office of Chief Statistician, Department of Statistics, personal communication.

NOTES:

... No data available; - zero exports.

a Data for 1963 converted from pikuls, the remainder from cwt. and rounded.

b 1960-1961 and 1967-1968 data converted from long tons, the remainder from cwt. and rounded. Data for 1974 are preliminary.

c Imports of Bangladesh included with those of Pakistan prior to 1972. 
TABLE 30. Direction of Import Trade in Pearl Sago, 1960-1974 (metric tons)

\begin{tabular}{|c|c|c|c|c|c|c|c|}
\hline $\begin{array}{l}\text { Country of } \\
\text { Origin }\end{array}$ & 1960 & 1961 & 1962 & 1963 & 1964 & 1965 & 1966 \\
\hline & \multicolumn{7}{|c|}{ To Brunei ${ }^{a}$} \\
\hline Australia & $\ldots$ & $\ldots$ & $\ldots$ & - & - & - & - \\
\hline China & $\ldots$ & $\ldots$ & $\ldots$ & - & - & - & - \\
\hline India & $\ldots$ & $\ldots$ & $\ldots$ & - & - & - & - \\
\hline Sarawak & $\ldots$ & $\ldots$ & $\ldots$ & - & 0.1 & 0.1 & 0.2 \\
\hline Singapore & $3.0^{\mathrm{b}}$ & 2.1 & $2.7^{\mathrm{b}}$ & 3.7 & 0.6 & 2.7 & 1.6 \\
\hline $\begin{array}{l}\text { Thailand } \\
\text { West }\end{array}$ & $\ldots$ & $\cdots$ & $\cdots$ & - & 0.3 & 1.2 & 1.7 \\
\hline Malaysia & $\ldots$ & $\ldots$ & $\ldots$ & - & - & - & 0.5 \\
\hline \multirow[t]{2}{*}{ Total } & $\ldots$ & $\ldots$ & $\cdots$ & 3.7 & 1.0 & 4.0 & 4.1 \\
\hline & \multicolumn{7}{|c|}{ To Sabah ${ }^{\mathrm{a}}$} \\
\hline China $^{c}$ & $\ldots$ & $\ldots$ & - & - & - & 0.2 & 0.8 \\
\hline France & $\ldots$ & $\ldots$ & - & - & 0.1 & - & - \\
\hline Hong Kong & $\ldots$ & $\ldots$ & - & 0.1 & - & 0.1 & - \\
\hline India & $\ldots$ & $\ldots$ & - & - & - & - & - \\
\hline Indonesia & $\ldots$ & $\ldots$ & - & 0.1 & - & - & - \\
\hline Japan & $\ldots$ & $\ldots$ & - & - & - & - & - \\
\hline Sarawak & $\ldots$ & $\ldots$ & - & - & - & - & - \\
\hline Singapore & $\ldots$ & $\ldots$ & 0.1 & 0.1 & 0.2 & 0.5 & 1.4 \\
\hline Switzerland & $\ldots$ & $\ldots$ & - & 0.1 & - & - & - \\
\hline Thailand & $\ldots$ & $\ldots$ & 14.0 & 14.8 & 3.6 & 4.3 & 5.2 \\
\hline \multicolumn{8}{|l|}{ West } \\
\hline Malaysia & $\ldots$ & $\ldots$ & 0.4 & 0.6 & 0.2 & 0.5 & 1.9 \\
\hline \multirow[t]{2}{*}{ Total } & $\ldots$ & $\ldots$ & 14.5 & 15.8 & 4.1 & 5.6 & 9.3 \\
\hline & \multicolumn{7}{|c|}{ To Sarawak } \\
\hline China $^{d}$ & $\ldots$ & $\ldots$ & 0.7 & 0.2 & 0.3 & 0.2 & 0.3 \\
\hline Hong Kong & $\ldots$ & $\ldots$ & 0.2 & - & 0.1 & - & 0.2 \\
\hline India & $\ldots$ & $\ldots$ & - & 0.1 & - & - & - \\
\hline Indonesia & $\ldots$ & $\ldots$ & 0.1 & 0.1 & - & - & - \\
\hline Japan & $\ldots$ & $\cdots$ & - & 0.3 & - & - & - \\
\hline Singapore & $\ldots$ & $\ldots$ & 9.7 & 11.7 & 9.8 & 9.8 & 11.6 \\
\hline Thailand & $\ldots$ & $\ldots$ & 6.2 & 4.4 & 4.4 & 5.6 & 6.5 \\
\hline \multicolumn{8}{|l|}{ United } \\
\hline Kingdom & $\ldots$ & $\ldots$ & - & - & - & - & - \\
\hline Vietnam & $\ldots$ & $\cdots$ & - & - & - & 0.1 & - \\
\hline \multicolumn{8}{|l|}{ West } \\
\hline Malaysia & & $\ldots$ & 3.1 & 3.6 & 2.7 & 3.9 & 6.0 \\
\hline Total & $\ldots$ & $\ldots$ & 20.0 & 20.4 & 17.3 & 19.6 & 24.6 \\
\hline
\end{tabular}


TABLE 30. (cont.)

\begin{tabular}{|c|c|c|c|c|c|c|c|}
\hline 1967 & 1968 & 1969 & 1970 & 1971 & 1972 & 1973 & 1974 \\
\hline- & - & - & - & - & - & 0.4 & _- \\
\hline - & 0.4 & - & - & - & - & - & - \\
\hline- & 0.1 & - & - & - & - & - & - \\
\hline - & - & 0.6 & 0.7 & 0.1 & 0.2 & 0.1 & - \\
\hline 1.8 & 2.4 & 1.8 & 0.7 & 2.4 & 1.1 & 2.2 & 0.5 \\
\hline 0.6 & 0.6 & 1.7 & 0.3 & 1.2 & 0.3 & 1.0 & - \\
\hline 0.1 & - & - & - & - & - & 0.4 & - \\
\hline 2.5 & 3.5 & 4.1 & 1.7 & 3.7 & 1.6 & 4.1 & 0.5 \\
\hline 0.7 & 1.5 & 0.4 & 1.4 & 3.5 & - & - & $\ldots$ \\
\hline- & - & - & - & - & - & - & $\ldots$ \\
\hline 0.1 & 0.1 & - & - & - & - & - & $\ldots$ \\
\hline- & - & - & - & - & - & - & $\ldots$ \\
\hline- & - & - & - & 0.1 & 1.0 & 0.1 & $\ldots$ \\
\hline- & - & - & - & 0.3 & - & - & $\ldots$ \\
\hline- & - & - & - & 0.1 & - & - & $\ldots$ \\
\hline 1.1 & 1.2 & 1.0 & 0.9 & 1.2 & 13.0 & 16.1 & $\ldots$ \\
\hline- & - & - & - & - & - & - & $\ldots$ \\
\hline 7.8 & 7.3 & 7.8 & 6.2 & 6.9 & 15.5 & 12.6 & $\ldots$ \\
\hline 1.6 & 1.3 & 2.7 & 2.7 & 3.1 & 4.0 & 5.7 & $\ldots$ \\
\hline 11.4 & I1.4 & 11.9 & 11.2 & 15.2 & 33.5 & 34.5 & $\ldots$ \\
\hline 0.4 & 2.2 & 0.4 & 0.5 & 0.2 & - & - & $\ldots$ \\
\hline 0.6 & 0.3 & - & - & - & - & - & $\ldots$ \\
\hline- & - & 0.1 & 0.1 & 0.3 & 0.2 & - & $\ldots$ \\
\hline- & - & 0.1 & - & 0.2 & 0.5 & 0.4 & $\ldots$ \\
\hline- & - & - & - & - & - & - & $\ldots$ \\
\hline 9.0 & 10.2 & 13.1 & 10.9 & 10.2 & 11.5 & 13.7 & $\ldots$ \\
\hline 7.5 & 5.7 & 5.6 & 3.7 & 3.1 & 3.5 & 3.2 & $\ldots$ \\
\hline- & - & - & - & - & - & - & $\ldots$ \\
\hline- & - & - & - & - & - & - & $\ldots$ \\
\hline 7.1 & 7.9 & 7.3 & 7.0 & 7.5 & 8.3 & 9.8 & $\ldots$ \\
\hline 24.6 & 26.3 & 26.6 & 22.2 & 21.5 & 24.0 & 27.1 & $\ldots$ \\
\hline
\end{tabular}


TABLE 30. (cont.)

\begin{tabular}{|c|c|c|c|c|c|c|c|}
\hline $\begin{array}{l}\text { Country of } \\
\text { Origin }\end{array}$ & f 1960 & 1961 & 1962 & 1963 & 1964 & 1965 & 1966 \\
\hline \multicolumn{8}{|c|}{ To Singapore ${ }^{\mathrm{e}}$} \\
\hline China ${ }^{c}$ & 10.0 & - & - & - & - & - & - \\
\hline \multicolumn{8}{|l|}{ United } \\
\hline Kingdom & - & - & - & - & - & - & - \\
\hline \multicolumn{8}{|l|}{ West } \\
\hline Malaysia & - & 19.9 & 0.5 & 2.9 & 5.3 & - & 9.1 \\
\hline Total & 10.0 & 19.9 & 0.5 & 2.9 & 5.3 & - & 9.1 \\
\hline \multicolumn{8}{|c|}{ To West Malaysia ${ }^{a}$} \\
\hline China" & - & - & - & 0.8 & - & - & - \\
\hline Hong Kong & - & - & - & - & - & - & - \\
\hline Indonesia & - & - & - & - & - & - & - \\
\hline Sabah & - & - & - & - & - & - & - \\
\hline Singapore & 0.5 & - & 3.6 & 0.6 & 0.6 & 8.6 & 8.6 \\
\hline Thailand & 1.3 & 10.2 & 0.9 & 0.6 & 0.6 & - & - \\
\hline Total & 1.8 & 10.2 & 4.5 & 2.0 & 1.2 & 8.6 & 8.6 \\
\hline
\end{tabular}


TABLE 30. (cont.)

\begin{tabular}{|c|c|c|c|c|c|c|c|}
\hline 1967 & 1968 & 1969 & 1970 & 1971 & 1972 & 1973 & 1974 \\
\hline 1.8 & - & - & - & - & - & - & - \\
\hline - & 0.3 & 0.2 & 0.1 & - & - & - & - \\
\hline 22.6 & 57.2 & 28.4 & $2,677.7$ & 478.1 & $1,096.4$ & 477.4 & 565.9 \\
\hline 24.4 & 57.5 & 28.6 & $2,677.8$ & 478.1 & $1,096.4$ & 477.4 & 565.9 \\
\hline 0.2 & 0.4 & 0.2 & 0.2 & 0.2 & - & 1.0 & 2.0 \\
\hline- & 0.2 & - & - & - & - & - & - \\
\hline 0.3 & 0,1 & 3,1 & 1.1 & 0.1 & 0.5 & 0.1 & 0.2 \\
\hline 0.1 & - & - & - & - & - & - & - \\
\hline 11.4 & 1.0 & 0.1 & 0.8 & 0.2 & 24.6 & 2.2 & 10.3 \\
\hline 0.9 & 0.2 & 39.5 & 44.4 & 0.1 & 19.1 & 2.4 & - \\
\hline 12.9 & 1.9 & 42.9 & 46.5 & 0.6 & 44.2 & 5.5 & 12.5 \\
\hline
\end{tabular}

SOURCES:

Brunei, Office of State Secretary, personal communication; State of Sabah, Department of Statistics, Statistics of External Trade, Sabah; State of Sarawak, Office of Senior Statistician, Department of Statistics, personal communication; Republic of Singapore n,d.; and West Malaysia, Office of Chief Statistician, Department of Statistics, personal communication.

NoTES:

... No data available; - zero imports.

a Converted from cwt. and rounded. 1974 data are for January through July only.

b Data from Singaporean source.

c People's Republic.

d Probably derived from manioc.

e Converted from long tons and rounded. Data for 1974 are for January through September only. 
TABLE 31. Sarawak: Exports of Pearl Sago, 1870-1973

\begin{tabular}{|c|c|c|c|c|c|}
\hline Year & M.T. & Year & M.T. & Year & M.T. \\
\hline $1870^{\mathrm{a}}$ & $\ldots$ & $1905^{b}$ & 0.8 & 1940 & $\ldots$ \\
\hline $1871^{a}$ & - & $1906^{b}$ & 10.2 & 1941 & $\ldots$ \\
\hline $1872^{\mathrm{a}}$ & $\ldots$ & $1907^{b}$ & 495.7 & 1942 & $\ldots$ \\
\hline $1873^{a}$ & $\ldots$ & $1908^{b}$ & 4.8 & 1943 & $\ldots$ \\
\hline $1874^{a}$ & - & $1909^{b}$ & 9.9 & 1944 & $\ldots$ \\
\hline $1875^{\mathrm{a}}$ & - & $1910^{b}$ & 26.0 & 1945 & $\ldots$ \\
\hline $1876^{\mathrm{a}}$ & - & $1911^{b}$ & 0.1 & 1946 & $\ldots$ \\
\hline $1877^{a}$ & $\ldots$ & $1912^{b}$ & 0.1 & 1947 & $\ldots$ \\
\hline $1878^{a}$ & $\ldots$ & $1913^{b}$ & 7.7 & 1948 & $\ldots$ \\
\hline $1879^{a}$ & $\ldots$ & $1914^{b}$ & 16.9 & 1949 & $\ldots$ \\
\hline $1880^{\mathrm{a}}$ & $\ldots$ & $1915^{b}$ & 0.6 & 1950 & $\ldots$ \\
\hline $1881^{a}$ & 1.5 & $1916^{b}$ & 15.2 & 1951 & $\ldots$ \\
\hline $1882^{\mathrm{a}}$ & 60.2 & $1917^{b}$ & - & 1952 & $\ldots$ \\
\hline $1883^{a}$ & 42.1 & $1918^{b}$ & - & 1953 & $\ldots$ \\
\hline $1884^{a}$ & 12.9 & $1919^{b}$ & - & $1954^{c}$ & $0.1^{\mathrm{d}}$ \\
\hline $1885^{\mathrm{a}}$ & 4.1 & $1920^{b}$ & - & $1955^{c}$ & $0.1^{d}$ \\
\hline 1886 & $\ldots$ & $1921^{b}$ & - & $1956^{c}$ & $1.0^{d}$ \\
\hline $1887^{\mathrm{a}}$ & 31.4 & 1922 & $\ldots$ & $1957^{c}$ & $0.2^{\mathrm{d}}$ \\
\hline $1888^{a}$ & 12.9 & 1923 & $\ldots$ & $1958^{\mathrm{c}}$ & $0.7^{\mathrm{d}}$ \\
\hline $1889^{\mathrm{a}}$ & 10.7 & 1924 & $\ldots$ & $1959^{c}$ & $1.3^{\mathrm{d}}$ \\
\hline $1890^{\mathrm{a}}$ & 5.3 & 1925 & $\ldots$ & $1960^{c}$ & $0.4^{\mathrm{d}}$ \\
\hline $1891^{\text {a }}$ & 24.1 & 1926 & $\ldots$ & $1961^{\circ}$ & $0.9^{d}$ \\
\hline 1892 & $\ldots$ & 1927 & $\ldots$ & 1962 & $\ldots$ \\
\hline $1893^{a}$ & 10.3 & 1928 & $\ldots$ & 1963 & $\ldots$ \\
\hline $1894^{B}$ & 0.5 & 1929 & $\ldots$ & 1964 & $\ldots$ \\
\hline 1895 & $\ldots$ & 1930 & $\ldots$ & 1965 & $\ldots$ \\
\hline 1896 & $\ldots$ & 1931 & $\ldots$ & 1966 & - \\
\hline 1897 & $\ldots$ & 1932 & $\ldots$ & $1967^{c}$ & - \\
\hline 1898 & $\ldots$ & 1933 & $\ldots$ & $1968^{\circ}$ & - \\
\hline 1899 & $\ldots$ & 1934 & $\ldots$ & $1969^{c}$ & $0.6^{d}$ \\
\hline 1900 & $\ldots$ & 1935 & $\ldots$ & $1970^{c}$ & $0.7^{d}$ \\
\hline 1901 & $\ldots$ & 1936 & $\ldots$ & $1971^{\mathrm{c}}$ & $0.2^{\mathrm{d}}$ \\
\hline $1902^{a}$ & 20.3 & 1937 & $\ldots$ & $1972^{\mathrm{c}}$ & $0.3^{\mathrm{d}}$ \\
\hline $1903^{a}$ & 0.8 & 1938 & $\ldots$ & $1973^{c}$ & $0.3^{d}$ \\
\hline $1904^{b}$ & 12.3 & 1939 & $\ldots$ & & \\
\hline
\end{tabular}

SOURCES:

a Sarawak Gazette, 2-8-1871:3; 2-15-1872:4; 2-17-1873:5; 3-2-1874:3; 3-16$1875: 4 ; 6-24-1876: 5 ; 8-25-1877: 67 ; 6-24-1878: 48 ; 5-23-1879: 36 ; 3-31-1880: 19$; 4-1-1881:37-8; 5-1-1882:33-4; 4-2-1883:32-3; 4-1-1884:28-9; 5-1-1885:51-2; 4-1-1886:67-8; 5-1-1888:63-4; 6-1-1889:90-1; 5-1-1890:70-1; 5-1-1891:79-80; 7-1-1891:133-4; 8-1-1894:133-4; 6-1-1895:113-4; 5-2-1903:100.

b Sarawak, Annual Report of the Treasury and the Post, Shipping and Customs Departments.

c State of Sarawak, Department of Statistics, personal communication.

Notes:

Includes re-exports; . . . no data available; - zero exports.

$\checkmark$ Converted from pikuls and rounded. 
TABLE 32. Sarawak: Imports of Pearl Sago, 1873-1973

\begin{tabular}{|c|c|c|c|c|c|}
\hline Year & M.T. & Year & M.T. & Year & M.T. \\
\hline $1873^{a}$ & $\ldots$ & $1907^{\mathrm{b}}$ & 61.8 & 1941 & $\ldots$ \\
\hline $1874^{a}$ & - & $1908^{b}$ & 30.9 & 1942 & $\ldots$ \\
\hline $1875^{a}$ & - & $1909^{b}$ & 16.9 & 1943 & $\ldots$ \\
\hline $1876^{a}$ & - & $1910^{b}$ & 9.5 & 1944 & $\ldots$ \\
\hline $1877^{a}$ & - & $1911^{b}$ & 7.5 & 1945 & $\ldots$ \\
\hline $1878^{a}$ & - & $1912^{b}$ & 59.0 & 1946 & $\ldots$ \\
\hline $1879^{a}$ & - & $1913^{b}$ & 29.2 & 1947 & $\ldots$ \\
\hline $1880^{\mathrm{a}}$ & - & $1914^{b}$ & 13.9 & 1948 & $\ldots$ \\
\hline $1881^{\mathrm{a}}$ & 3.2 & $1915^{b}$ & 26.9 & 1949 & $\ldots$ \\
\hline $1882^{a}$ & 68.8 & $1916^{b}$ & 36.4 & 1950 & $\ldots$ \\
\hline $1883^{a}$ & 46.3 & $1917^{b}$ & 8.7 & 1951 & $\cdots$ \\
\hline $1884^{a}$ & 42.9 & $1918^{b}$ & 3.6 & 1952 & $\ldots$ \\
\hline $1885^{a}$ & 17.7 & $1919^{b}$ & 11.1 & 1953 & $\ldots$ \\
\hline 1886 & $\ldots$ & $1920^{b}$ & 91.6 & $1954^{\mathrm{f}}$ & 20.1 \\
\hline $1887^{a}$ & 55.3 & $1921^{\mathrm{b}}$ & 32.4 & $1955^{f}$ & 17.8 \\
\hline $1888^{a}$ & 21.2 & $1922^{\mathrm{b}}$ & 5.5 & $1956^{f}$ & 19.4 \\
\hline $1889^{\mathrm{a}}$ & 15.5 & $1923^{b}$ & $6.6^{\mathrm{g}}$ & $1957^{f}$ & 18.0 \\
\hline $1890^{\mathrm{a}}$ & 13.6 & $1924^{\mathrm{b}}$ & $3.6^{\mathrm{B}}$ & $1958^{f}$ & 19.7 \\
\hline $1891^{a}$ & 39,9 & $1925^{b}$ & $16.0^{\mathrm{B}}$ & $1959^{f}$ & 20.2 \\
\hline 1892 & $\ldots$ & $1926^{b}$ & $30.8^{8}$ & $1960^{f}$ & 21.6 \\
\hline $1893^{a}$ & 31.8 & $1927^{\mathrm{c}}$ & $14.9^{\mathrm{g}}$ & $1961^{f}$ & 24.7 \\
\hline $1894^{\mathrm{a}}$ & 5.4 & $1928^{c}$ & $10.4^{8}$ & $1962^{f}$ & 20.0 \\
\hline 1895 & $\ldots$ & $1929^{d}$ & $43.2^{\mathrm{g}}$ & $1963^{f}$ & 21.4 \\
\hline 1896 & $\ldots$ & $1930^{c}$ & $10.9^{8}$ & $1964^{f}$ & 15.2 \\
\hline 1897 & $\ldots$ & $1931^{\circ}$ & $24.9^{\mathrm{g}}$ & $1965^{f}$ & 17.4 \\
\hline 1898 & $\ldots$ & $1932^{d}$ & $41.5^{\mathrm{g}}$ & $1966^{\mathrm{f}}$ & 24.5 \\
\hline 1899 & $\ldots$ & $1933^{4}$ & $45.7^{8}$ & $1967^{f}$ & 24.5 \\
\hline $1900^{\mathrm{a}}$ & 5.7 & $1934^{d}$ & $54.8^{8}$ & $1968^{f}$ & 26.4 \\
\hline 1901 & $\ldots$ & $1935^{d}$ & $49.2^{\mathrm{g}}$ & $1969^{f}$ & 26.5 \\
\hline 1902 & $\ldots$ & $1936^{d}$ & $31.7^{8}$ & $1970^{f}$ & 22.2 \\
\hline $1903^{a}$ & 8.6 & $1937^{d}$ & $32.1^{8}$ & $1971^{f}$ & 21.5 \\
\hline $1904^{b}$ & 9.0 & $1938^{d}$ & $23.0^{\mathrm{g}}$ & $1972^{f}$ & 24.0 \\
\hline $1905^{b}$ & 16.7 & $1939^{d}$ & $83.0^{\mathrm{g}}$ & $1973^{f}$ & 27.1 \\
\hline $1906^{b}$ & 60.7 & $1940^{d}$ & $38.5^{\mathrm{B}}$ & & \\
\hline
\end{tabular}

SOURCES:

a Sarawak Gazette, 3-2-1874:3; 3-16-1874:4; 6-24-1876:5; 8-25-1877:67; 6-24$1878: 48 ; 5-23-1879: 36 ; 3-31-1880: 19 ; 4-1-1881: 37-8 ; 5-1-1882: 33-4 ; 4-2-1883: 32-3 ; 4-$ $1-1884: 28-9 ; \quad 5-1-1885: 51-2 ; \quad 4-1-1886: 67-8 ; 5-1-1888: 63-4 ; 6-1-1889: 90-1 ; 5-1-$ $1890: 70-1 ; \quad 5-1-1891: 79-80 ; \quad 7-1-1892: 133-4 ; \quad 8-1-1894: 3-4 ; \quad 6-1-1895: 113-4 ; \quad 4-1-$ $1901: 78 ; 5-2-1903: 100$.

b Sarawak, Annual Report of the Treasury and the Post, Shipping, and Customs Department.

c Supplement to the Sarawak Government Gazette, July 16,1929.

d Sarawak, Department of Trade, Customs and Shipping Office: Annual Statistics and Accounts.

e Sarawak, Administration Report.

f State of Sarawak, Department of Statistics, Office of Chief Statistician, personal communication.

NoTes:

Data converted from pikuls until 1940, and thereafter from long tons, and rounded; . . . no data available; - zero imports.

8 From 1923 until 1940, inclusive, Pearl Sago and Sago Pith imports combined in source. 


\section{7 \\ THE FUTURE OUTLOOK FOR SAGO PRODUCTION}

The production of edible starch by the crushing, grinding, grating or macerating, and washing of plant parts in water, both to remove actively poisonous or acidic principles and to facilitate the sedimentation of starch, followed by fermenting and cooking of the product, is an ancient food-production technology of worldwide distribution. Such processes are akin to those used in retting for fiber extraction, in the manufacture of bark cloth, and in the preparation of ingredients for beverage- and medicine-making. Although not limited to the tropical and subtropical realms this method of starch production appears to have undergone its best development there, involving taxa of diverse plants such as palms, cycads, ferns, yams, and aroids.

Ethnobotanical data suggest a gradual replacement of that ancient starch technology over most of the world by higher levels of food production based on more developed agricultural systems. In some tropical regions occupied by root cultivators, where attention has focused primarily on individual plants, rather than on monocultural fields in which plants have fairly uniform characteristics, the traditional starch-extraction technology has persisted to the present. Among certain seed cultivators, however, the complex has largely been replaced as a major subsistence activity.

Such replacement is most clearly indicated for the mainland and islands of South and Southeast Asia, where the once dominant yam-taro-sago food complex gradually retreated eastwards as wet 
rice cultivation spread into the region (Burkill 1951:445-466). ${ }^{1}$ There is linguistic evidence in support of this. The Javanese word for boiled rice (sega) is derived from sagu (sago), an indication that the Javanese, one of the oldest rice-growing peoples of Indonesia, probably relied on sago before the introduction of rice (Ave pers. comm.). Spencer (1961:83) argues that the retreat of the yam-taro-sago complex must have been a fairly recent phenomenon, as considerable time is required to select seed and develop cultivars for local conditions. Bouman (1922:84) supports this view, noting that, as recently as 1922, the Bukat and Punan Dyak groups, who were formerly sago-makers and hunters, were gradually adopting shifting cultivation of upland rice.

The replacement of the yam-taro-sago complex appears to be related to the migration of peoples possessing more advanced agricultural technologies which involved terracing and water control (Spencer 1961:83), and to the cultural borrowing by preexisting groups within regions of inmigration. Where agriculture has been precluded, such as in swampy lowland areas of the island of Borneo, and parts of Melanesia, the production of palm sago has not been replaced, advanced agriculture being uneconomic, without a massive capital investment, in those localities. Locally, within some agricultural regions of South and Southeast Asia and Melanesia, palm sago production has not been entirely replaced, and it continues to provide secondary, specialized, and preferred traditional foodstuffs, in addition to retaining a magico-religious importance.

Four main factors contribute to the continued local importance of palm sago: technological levels, local economics, ritual and belief, and food preference. In some of the main contemporary sago-producing regions-coastal New Guinea, Sarawak, Kalimantan, and the lower Orinoco Delta-alternative means of livelihood are not generally available, at the current technological levels of the inhabitants. In those regions Metroxylon and Mauritia, palms tolerant of hygric sites, are the only producers of significant quantities of starch, for potentially competing root or grain starches cannot be widely produced without prohibitively expensive engineering projects to control periodic flooding.

Projects devised in Sarawak to modernize sago production and to promote better cultivation of Metroxylon palms, as the basis for the integral development of the state's vast tracts of equatorial 
freshwater peat swamps, indicate a strong belief in the potential of the large-scale development of this resource to support a considerable number of rural people. Sarawak sago starch, it is envisaged, refined according to the most stringent criteria-as exemplified by Sarawak Chemical Industries-will be competitive in the world market for industrial starches.

Along the western lowlands of Sabah, where Metroxylon palms abound, agricultural development for the cultivation of rice, Sabah's basic staple, has almost reached the limits of land that can be converted into padi without an enormous outlay of cash. The problem of devising low-cost alternative technologies for the development of the marginal swampy, lands which remain, must shortly be confronted.

Such a low-cost technology may feasibly be based on the native sago industry, which can, with relatively modest inputs, be rendered vastly more productive, and made to produce a much higher grade of sago flour.

Among the detailed problems to be solved in the development of Sabah's sago industry are:

1) expansion of area under palms;

2) development of sound cultivation techniques;

3) devising a sago-cultivation system which enables the interplanting of a series of catch crops;

4) breeding experiments to shorten the maturation period;

5) improvement of starch productivity and the extraction process;

6) improvement of flour quality, with processing taking place under more sanitary conditions;

7) filtration of water used in processing;

8) better use of byproducts;

9) experimentation to evaluate potential of waste water for use as a rubber coagulant; ${ }^{2}$

10) improved marketing and distribution system within Sabah, and investigation of potential overseas markets.

Besides being one of the few crops tolerant of the superhumid freshwater equatorial peat swamp environment, sago may soon enjoy a resurgence of popularity in Sabah, as its price advantage over rice and wheat flour increases. Information obtained from a 
sago flour retailer in the Tuaran market indicates that, although many of his customers enjoy eating sago and prefer it over other starches, others have no choice but to eat it because of its relative cheapness, despite a tripling of sago prices since 1973 .

In sago-producing areas of Sarawak, Sabah, and Indonesia, where cash economies operate, sago represents a cheap, locallyavailable foodstuff. Thus it remains important for local human consumption and shows an increasing potential as an animal feedstuff. There, until recently, the importance of sago production was reinforced by providing an economic role for women where cash-producing alternatives were not generally available to them.

Other reasons for the continued importance of palm sago are somewhat more localized. The fundamental importance of palm sago to both Waraoan and Kiwaian magico-religious systems, and those of other sago-dependent tribes, is clear. As the integrity of such tribal societies is progressively eroded by the encroachment of nontribal rural populations, palm starch, together with other traditional foodstuffs, sometimes assumes the position of a "prestige" or preferred food, consumed by older folk who may continue to maintain cherished ancient traditions (Roth 1896:423). Alternatively, in some such situations members of a community may regard the more recently adopted foodstuffs as more prestigious and reject sago entirely except in times of want:

\section{SAGO AND RICE: A SINGSING FROM DAGUA}

Sago, the worst food, black stuff-

I hate eating it!

Sago, the worst black stuff-

I hate eating it!

Rice ... the most marvellous food of all!

How happy the women are:

Proud and happy as they can be,

When they first cook rice!

A hungry old man:

Longs for rice when he sees them eating;

The greedy women refuse,

Refuse to give some to that old man.

Very sad is the old man:

He will never taste that marvellous food, rice,

Until he cooks his own.

(Wio n.d.: 13 transl.) 
Although palm-sago production has declined over the last several centuries there are indications that this trend could be reversed and sago regain some of its former importance beyond the present main producing regions. It may play a role in the cheap utilization of marginal environments, and in the recovery of sites severely damaged at the hand of man. Economic data from Sarawak, for example, indicate that the palm starch can remain competitive with other starches. The productivity of Metroxylon could be vastly increased by exploiting it as a commercial crop; the number of harvestable stems available (estimated at $40-$ $60 / \mathrm{ha} /$ year in Sarawak) is double that now exploited, indicating that the potential increase in Metroxylon sago could satisfy the demands of the potential local increase resulting from the mechanization of the extraction process.

Arenga pinnata and Eugeissona utilis, dryland sago palms adapted to poor quality, degraded, lateritic soils of mesic sites such as denuded hillsides, may be used as a soil-stabilizing component of an agricultural system devised to recover lands now virtually useless for cropping in the food-short areas of Java (Dransfield pers. comm.). ${ }^{3}$ Moreover, palms of these genera have the advantage of being tolerant of full sunlight; have seedlings relatively tolerant of accidental burning; and are already familiar to local populations. As part of a new system several intercalary catch crops could be grown between the rows of palms during the early maturation period.

The systematic exploitation of Arenga, Mauritia, and Metroxylon palms, which yield stem starch as one of several potentially commercial products, and which are all tolerant of poorer quality soils, could provide a continuing cash income to marginal societies. Properly managed, the starch productivity of palm-based cultivation systems could be maintained indefinitely on relatively small tracts of land, a significant factor in an era when many rural populations are scrambling to survive with a diminishing renewable natural resource base. Moreover, the limited capital resources available to marginal societies would not be dissipated as quickly under a system which includes palm cultivation as it might be under most systems of shifting cultivation, which traditionally have been the easiest alternative means of ensuring subsistence in many of the areas which we have been considering. 


\section{NOTES}

\section{Chapter 1}

1. The two leading palm taxonomists in the United States disagree about the yalidity of the genus Arecastrum. Moore (1973a:110) considers it to be valid; Glassman (1972:12-13) treats it as synonym of Syagrus.

\section{ChAPTER 2}

1. The almost universal technique of washing the pulp to obtain starch could represent the diffusion of a European innovation. Sturtevant (1969) studied the ethnography of West Indian starches and concluded that the washing technique was introduced by Europeans and had replaced the aboriginal technique for processing bitter manioc (grating and squeezing out the toxic juices) and the cycad, Zamia (grating and fermentation).

2. Sago Grub

"Me! The village kids' favourite.

Mother finds me hard to find.

But kids find me delicious to eat!"

(Anduari n.d.:13)

\section{ChAPTER 3}

1. This represents a somewhat rapid change in Fiji, where Seemann (1865-1873: 279), not many years earlier described Metroxylon palms as " . . growing in swamps on Viti Levu, Vanua Levu, and Ovalau [but the] natives of Fiji were unacquainted with the nutritious qualities residing in the trunk, until Mr. Pritchard and myself extracted the sago from it."

2. See table 4 .

3. Flach, in West Malaysia, and Sim, in Sarawak, have done research on Metro$x y$ lon yields. The results, as yet unpublished, contain data on yields far superior to those in available sources. 
4. These may possibly be Arenga spp. (cf. Lecomte 1808-1842, vol. 6:964).

5. The term pagahan is probably a cognate of puguhan (Mbo) and pugahan (Tagalog) (Merrill 1925, vol. 1:158).

6. Binomial derived from Steiner 1961:276.

7. Identified from central Visayan cognates, ibiók, idióg, and idiók, locally used for Arenga pinnata (Merrill 1925, vol. 1:160).

\section{ChAPTER 4}

1. The Sanio-Hiowe initially place a corpse on a platform and later dispose of the bones by burial or by placing them in a pool of water.

2. Eight named varieties of sago were recorded from the Sanio-Hiowe.

3. Where women pound, and men wash, in the reverse of the usual division of labor.

\section{ChAPTER 6}

1. The following four paragraphs are derived exclusively from information contained in the annual reports of the Singapore (International) Chamber of Commerce, which, until 1965, contained current information on the status of the sago business. Citations refer to Singapore External Trade, Republic of Singapore, various years.

\section{Chapter 7}

1. Field observations by Heinen (1972:64, 589) and Wilbert (pers. comm.) indicate that a similar phenomenon has been taking place since the $1920 \mathrm{~s}$ among some Warao groups of the Orinoco Delta, where, in particular localities, taro introduced from the Guianas has replaced Mauritia sago as the main starch source.

2. According to a Bisaya informant, highly acidic waste water from the sago troughs was used as a coagulant by rubber producers during the Japanese occupation, when acetic acid was not available.

3. Sago derived from Arenga pinnata was once an important foodstuff in Western Java, where ". . . (it) is the only source of sago, while in the Western and poorer part of the island is used in considerable quantity, and offered for sale in all the markets" (Seemann 1856:69). 


\section{BIBLIOGRAPHY}

Adriani, N., and Kruyt, A. C. 1951. De Bare'e Sprekende Toradjas van MiddenCelebes. Vol. 3. Amsterdam: Koninklijke Nederlandse Akademie van Wetenschappen. (Translation by J. K. Moulton for the Human Relations Area Files, 1970.)

Alkema, B., and Bezemer, T. J., 1927. Beknopt Handboek der Volkenkunde van Nederlandsch-Indië. Haarlem: H. D. Tjeenk Willink.

Amelsvoort, V. F. P. M. van. 1964. Culture, Stone Age and Modern Medicine. Assen: Van Gorcum.

Anduari, C. N.d. Sago Grub. In Sago and Rice: An Anthology of Poems Written by Students of Brandi High School Wewak, edited by N. Gregory. Multilith. Wewak, New Guinea.

Baal, J. van. 1966. Dema: Description and Analysis of Marind-anim Culture. The Hague: Martinus Nijhoff.

Barrau, J. 1958. Subsistence Agriculture in Melanesia. Bernice P. Bishop Museum Bulletin 219. Honolulu.

1959. The Sago Palms and Other Food Plants of Marsh Dwellers in the South Pacific Islands. Economic Botany 13:151-163.

1961. Subsistence Agriculture in Polynesia and Micronesia. Bernice P. Bishop Museum Bulletin 223. Honolulu.

Bartlett, H. H. 1963. Fire in Relation to Primitive Agriculture and Grazing in the Tropics. Vol. 4 Mimeograph. Ann Arbor: University of Michigan Department of Botany.

Beaver, W. N. 1920. Unexplored New Guinea. London: Seeley, Service.

Beccari, O. 1904. Wanderings in the Great Forests of Borneo, London: Constable and $\mathrm{Co}$.

Blackwood, B. 1935. Both Sides of the Buka Passage. Oxford: Clarendon Press.

Blake, D. H. 1972. Western District. In Encyclopaedia of Papua and New Guinea, edited by P. Ryan. Melbourne: Melbourne University Press in association with University of Papua and New Guinea. 
Blatter, E. 1926. The Palms of British India and Ceylon. London and New York: Oxford University Press.

Boediono. 1972. An Economic Survey of North Sulawesi. Bulletin of Indonesian Economic Studies 8:66-92.

Boelaars, J. H. M. C. 1958. Papoea's aan de Mappi. Utrecht: De Fontein.

Boon, O. C. 1973. Some Observations on the Use of Sago in Pig Rations Supplemented with Either Fish Meal or Soybean Meal. The Malaysian Agricultural Journal 49:208-213.

Bouman, M. A. 1922. Gegevensuit Smitau en Boven-Kapuas. Adatrechtbundels 44(Borneo):47-86. The Hague: Martinus Nijhoff.

Bretschneider, E. 1881, Botanicum Sinicum: Notes on Chinese Botany from Native and Western Sources. Journal of the North-China Branch of the Royal Asiatic Society n.s, 16:18-230, and n.s. 25:1-468.

Broek, J. O. M. N.d. Trade and Trade Centers of Sarawak. Mimeograph. Minneapolis: Department of Geography, University of Minnesota.

Brookfield, H. C., with Hart, D. 1971. Melanesia: A Geographical Interpretation of an Island World. London: Methuen.

Buck, J. L. 1930. Chinese Farm Economy. Chicago: University of Chicago Press.

Burhamzah. 1970. An Economic Survey of Maluku. Bulletin of Indonesian Economic Studies 6:31-45.

Burkill, I. H. 1935. A Dictionary of the Economic Products of the Malay Peninsula. 2 vols. London: Crown Agents for the Colonies.

1951. The Rise and Decline of the Greater Yam in the Service of Man. Advancement of Science 7:443-448.

Burridge, K. 1969. Tangu Traditions, Oxford: Clarendon Press.

Carneiro, R. L. 1957. Subsistence and Social Structure. Ph.D. dissertation. Ann Arbor: University of Michigan.

Central Food Technology Research Institute. 1955. The Indian Sago Industry. Mysore: Central Food Technology Res. Inst.

Chinnery, E. W. P. 1929. Studies of the Native Population of the East Coast of New Ireland. Territory of New Guinea Anthropological Report No. 6. Canberra: Government Printer.

Clastres, P. 1968. Ethnographie des Indiens Guayakí (Paraguay-Brésil). Journal de la Société des Americanistes 57:8-61.

1972. The Guayakí. In Hunters and Gatherers Today, edited by M. G. Bichieri. New York: Holt, Rinehart and Winston.

Codrington, R. H. 1891. The Melanesians: Studies in Their Anthropology and Folklore. Oxford: Clarendon Press.

Cohen, H. 1939. De Economische Beteekenis der Bosch-Bijproducten van de Buitengewesten. Koloniale Studiën 23:460-496.

Cole, F. C. 1913. The Wild Tribes of Davao District, Mindanao. Field Museum of Natural History Publication 170, Anthropological Series 12. Chicago.

Conklin, H. C. 1957. Hanunó Agriculture. A Report on an Integral System of Shifting Cultivation in the Philippines. Rome: United Nations Food and Agricultural Organization. 
Cook, W. A. 1907. The Bororo Indians Mato Grosso, Brazil. Smithsonian Institution Miscellaneous Collection 50:48-62. Washington, D.C.

Cooley, F. L. 1962. Altar and Throne in Central Moluccan Societies. Ph.D. dissertation. Ann Arbor: University Microfilms.

1967. Allang: A Village on Ambon Island. In Villages in Indonesia, edited by Koentjaraningrat. Ithaca, N.Y.: Cornell University Press.

Corden, M. W. 1970. Some Observations on Village Life in New Guinea. Aus tralian Institute of Anatomy, Food and Nutrition, Notes and Review 27:77-82.

Corner, E. J. H. 1966. The Natural History of Palms, London: Weidenfeld and Nicolson.

Dampier, W. 1729. A Collection of Voyages. 4 vols. London. Printed for J. and J, Knapton.

Dewall, H. von. 1862. Matau, Simpang, Soekadana, de Karimata-eilanden en Koeboe (wester-afdeeling van Borneo). Tijdschrift voor Indische Taal-, Land-, en Volkenkunde 2:1-146.

Dornstreich, M. D. 1973. An Ecological Study of Gadio Enga (New Guinea) Subsistence. Ph.D. dissertation. Ann Arbor: University Microfilms.

Drabbe, P. 1940. Het Leven van den Tanémbareers: Ethnografische Studie over het Tanémbareesche Volk. Leiden: E. J. Brill.

Drury, H. 1858. The Useful Plants of India. Madras: Asylum Press.

Dunsmore, J. R. and Ong, C. B. 1970. A Preliminary Poultry Feeding Trial in Sarawak. The Malaysian Agricultural Journal 47:344-356.

Edwards, E. T. 1961. The Natural Stands of Sago Palms, Metroxylon spp., in the Sepik River Area of New Guinea and their Possible Use as a Source of Commercial Starch. Mimeograph. Report submitted to the Board of Directors of Geo. Fielder and Co., Ltd., Sydney.

Eechoud, J. P. K. van. 1962. Etnografie van de Kaowerawédi (Centraal NieuwGuinea). Verhandelingen van het Koninklijk Instituut voor Taal-, Land- en Völkenkunde 37. The Hague: Martinus Nijhoff.

Ellen, R. F. 1975. Non-domesticated Resources in Nuaulu Ecological Relations. Social Science Information 14:127-150.

Elmberg, J, E. 1955. Field Notes on the Mejbrat People in the Ajamaru District of the Birds' Head (Vogelkop), Western New Guinea. Ethnos 20:3-102.

1968. Balance and Circulation: Aspects of Tradition and Change among the Mejbrat of Irian Barat. Ethnografiska Museum Monograph Series 12. Gothenburg.

Fairweather, J. and Yap, S. T. 1937. The Sago Industry in Malaya. Malayan Agricultural Journal 25:329-333.

Federation of Malaya. 1960. Census of Agriculture, 1960. Preliminary Report No. 10, Permanent Crops: Compact Areas and Scattered Trees. (Published 1962.) Kuala Lumpur.

Fernandez, C. A. and Lynch, F. 1972. The Tasaday: Cave-Dwelling Food Gatherers of South Cotabato, Mindanao. Philippine Sociological Review 20:275-330.

Finley, J. P. and Churchill, W. 1913. The Subanu: Studies of a Sub-Visayan 
Mountain Folk of Mindanao. Carnegie Institution Publication 184. Washington, D.C.

Firth, R. 1930. Report on Research in Tikopia. Oceania 1:105-117.

1950. Economics and Ritual in Sago Extraction in Tikopia, Mankind 4:131-142,

Flach, M. 1972. Van natuurlijk bestand naar plantverband; de sago palm. Wageningen: H. Veenman en Zonen N. V. (Cited in Tropical Abstracts 12:854.)

Fortgens, J. 1909. Sagoe en Sagoepalmen. Bulletin van Het Koloniaal Museum te Haarlem 44:70-104.

Fortune, R. F. 1932. Sorcerers of Dobu-The Social Anthropology of the Dobu Islanders of the Western Pacific. New York; Dutton and Co.

1942. Arapesh. American Ethnological Society Publication 19. New York: J. J. Augustin.

Frazer, J. G. 1911. The Golden Bough. 3rd ed. London: Macmillan.

Galis, K. W. N.d. Papua's van de Humboldt Baai. The Hague: J. N. Voorhoeve.

Garnaut, R. and Manning, C. M. 1973. An Economic Survey of West Irian, Pt. 2. Bulletin of Indonesia Economic Studies 9:30-64.

Geddes, W. R. 1954. The Land Dyaks of Sarawak. Colonial Research Studies 14. London: H. M. S. O.

Gerbrands, A. A. 1967. Wow-ipits. The Hague: Mouton.

Geurtjens, H. 1921. Uit een Vreemde Wereld. Bois-le-Duc: Teulings.

Glassman, S. F, 1972. A Revision of B. E. Dahlgren's Index of American Palms. Phanerogamarum Monographiae 6. Germany: J. Cramer.

Gourou, P. 1931. L'Indochine Francaise: Le Tonkin. Paris: Exposition Coloniale Internationale,

Graebner, F. 1909. Völkerkunde der Santa-Cruz-Inseln. Ethnologica: Rautenstrauch-Joest Museums für Völkerkunde, Köln. Leipzig: Hiersemann Verlag.

Griffith, W. 1850. Palms of British East India. Calcutta: Government of Bengal.

Grist, D. H. 1936. An Outline of Malayan Agriculture. Kuala Lumpur: Department of Agriculture, Straits Settlements and Federated Malay States.

Gross, G. W.; Ding, E.; and Groff, E. H. 1923. An Enumeration of the McClure Collection of Hainan Plants. Lingnaam Agricultural Review 1:27-85.

Groves, M. 1972. Hiri. In Encyclopaedia of Papua and New Guinea, edited by P. Ryan. Melbourne: Melbourne University Press in association with University of Papua and New Guinea.

Guiart, J. 1958. Espiritu Santo (Nouvelles-Hebrides). Paris: Librairie Plon.

Guppy, H. B. 1906. Observations of a Naturalist in the Pacific between 1896 and 1899. 2 vols. London: Macmillan Co.

Haberland, E. 1966a. Zur Ethnographie der Alfendio-Region (Südlicher SepikDistrikt, Neuguinea). Jahrbuch des Museums für Völkerkunde zu Leipzig 23:33-67. 1:81-101.

Haberland, E. and Seyfarth, S. 1974. Die Yimar am Oberen Korowori (Neuguinea). Studien zur Kulturkunde 36. Wiesbaden: Franz Steiner. 
Harding, T. G. 1967. Voyagers of the Vitiaz Strait. Seattle: University of Washington Press.

Hart, D. V. 1954. Barrio Caticugan: A Visayan Filipino Community. D.Sc. dissertation. Syracuse University.

Haswell, M. R. 1953, Economics of Agriculture in a Savannah Village. Colonial Research Series 8. London: H. M. S. O.

Heinen, H. D. 1972. Adaptive Changes in a Tribal Economy: A Case Study of the Winikina-Warao. Ph.D. dissertation. High Wycombe: University Microfilms.

Heinen, H. D. and Ruddle, K. 1974. Ecology, Ritual, and Economic Organization in the Distribution of Palm Starch among the Warao of the Orinoco Delta. Journal of Anthropological Research 30:116-138.

Held, G. J. 1957. The Papuas of Waropen. The Hague: Martinus Nijhoff. Henry, J. 1964. Jungle People: A Kaingang Tribe of the Highlands of Brazil. New York: Vintage Books.

Hines, C. W. 1914. Sugar-Palm Sap. Philippine Agricultural Review 7:222-228. Hipsley, E. H. 1947. Report on Health and Nutritional Status. In Report of the New Guinea Nutrition Survey Expedition, edited by E. H. Hipsley and F. W. Clements, pp, 144-176.

Hipsley, E. H. and Clements, F. W., eds. 1947. Report of the New Guinea Nutrition Survey Expedition. Sydney; Government Printer.

Hogbin, H. I. 1939. Tillage and Collection: A New Guinea Economy. Oceania 9:127-151, 286-325.

1951. Transformation Scene: The Changing Culture of a New Guinea Village. London: Routledge and Kegan Paul.

Hughes, I. 1970. Pigs, Sago and Limestone: The Adaptive Use of Natural Enclosures and Planted Sago in Pig Management. Mankind 7:272-278.

Institute of Developing Economies. Various years. Foreign Trade of China. Tokyo: Institute of Developing Economies.

Ivens, W. G. 1927. Melanesians of the South-East Solomon Islands. London: Kegan Paul, Trench, Trubner and Co.

Jackson, J. C. 1968. Sarawak: A Geographical Survey of a Developing State. London: University of London Press.

Jalaludin, S.; Cheong, W. W.; Mahmud, A.; and Choo, C. G. 1970. Utilization of Sago for Growth in Fowl. The Malaysian Agricultural Journal 47:492:498.

Jamuh, G. and Harrisson, T. 1969. Bornean Cooking-(Malay, Melanau, Sea Dayak). Sarawak Museum Journal n.s. 17;202-230.

Janzen, D. H. 1974. Tropical Blackwater Rivers, Animals, and Mast Fruiting by the Dipterocarpaceae. Biotropica 6:69-103.

Jensen, A. E. 1939. Hainuwele: Volkserzählungen von der Molukken-Insel Ceram. Frankfurt-am-Main: Vittorio Klosterman. 1963. Myth and Cult among Primitive Peoples. Translated by M. T. Choldin and W. Weissleder. Chicago: University of Chicago Press.

Josselin de Jong, J. P. B. de. 1947. Studies in Indonesian Culture 2. The Community of Erai (Wetar). Verhandelingen der Koninklijk Nederlandsche Akademie van Wetenschappen, Afdeeling Letterkunde 50:1-152. 
Kelly, R. C. 1974. Etoro Social Structure. Ph.D. dissertation. Ann Arbor: University Microfilms.

Kerchove de Denterghem, O. de. 1878. Les Palmiers. Paris: J. Rothchild.

Kingdom of Thailand. Various years. Foreign Trade of Thailand. Bangkok: Department of Customs.

Kitzke, E. D. and Johnson, D. 1975. Commercial Palm Products Other than Oils. Principes 19:3-26.

Knight, J. W. 1969. The Starch Industry. Oxford: Pergamon Press.

Koster, H. 1817. Travels in Brazil. 2 vols. London: Longman, Hurst, Rees, Orme and Brown.

Kouwenhove, W. J. H. 1956. Nimboran: A Study of Social Change and SocioEconomic Development in a New Guinea Society. The Hague: J. N. Voorhoeve.

Landtman, G. 1927. The Kiwai Papuans of British New Guinea. London: Macmillan and Co.

Langley, D. 1947. Food Consumption and Dietary Levels. In Report of the New Guinea Nutrition Survey Expedition, edited by E. H. Hipsley and F. W. Clements, pp. 93-142.

Lea, D. A. M. 1964. Abelam Land and Sustenance. Ph.D. dissertation. Canberra: Australian National University.

1972. Indigenous Agriculture. In Encyclopaedia of Papua and New Guinea, edited by P. Ryan. Melbourne: Melbourne University Press in association with University of Papua and New Guinea.

LeBar, F. M., ed. 1972. Ethnic Groups of Insular Southeast Asia. Vol 1: Indonesia, Andaman Islands, and Madagascar. New Haven: Human Relations Area Files Press:

Lecomte, H. 1808-1842. Flore Générale de L'Indo-Chine. 6 vols. Paris: Masson et $\mathrm{Cie}$.

Lee, R. B. 1968. What Hunters Do for a Living, or, How to Make Out on Scarce Resources. In Man the Hunter, edited by R. B. Lee and I. Devore. Chicago: Aldine Publishing Co.

Leeden, A. C. van der. 1956. Hooftrekken der Sociale Struktuur in Het Westelijke Binnenland van Sarmi. Leiden: Eduard Ijdo.

Lim, J. S. 1974. A Short Account of Sago Production in Kuala Balai-Balit. The Brunei Museum Journal 3:144-155.

Low, H. 1848. Sarawak: Its Inhabitants and Productions. London: Richard Bentley.

Luyken, R. and Luyken-Koning, F. W. M. 1955. Nutritional State of the Marind-Anim Tribe in South New Guinea. Documenta de Medicina Geographica et Tropica 7:315-330.

Maher, R. F. 1961. New Men of Papua. Madison: University of Wisconsin Press.

Malinowski, B. 1915. The Natives of Mailu. Transactions and Proceedings of the Royal Society of South Australia 39:494-706. 1922. Argonauts of the Western Pacific, London: Routledge and Sons.

Manning, C. W. and Garnaut, R. 1972. An Economic Survey of West Irian. Pt. 1. Bulletin of Indonesian Economic Studies 8:33-65. 
McAlpine, J, 1972. Southern Highlands District. In Encyclopaedia of Papua and New Guinea, edited by P. Ryan. Melbourne: Melbourne University Press in association with University of Papua and New Guinea.

McArthur, M. 1972. Food. In Encyclopaedia of Papua and New Guinea, edited by P. Ryan. Melbourne: Melbourne University Press in association with University of Papua and New Guinea.

Mead, M. 1970. The Mountain Arapesh: Arts and Supernaturalism. Vol. 2. Garden City, N.Y.: Natural History Press.

Merrill, E. D. 1925. An Enumeration of Philippine Flowering Plants. 4 vols. Manila: Bureau of Printing.

Merrill, E. D. and Robinson, C. B. 1917. An Interpretation of Rumphius' Herbarium Amboinense. Bureau of Science Publication 9. Manila: Department of Agriculture and Natural Resources.

Métraux, A. 1928. La Civilization Matérielle des Tribus Tupi-Guarant. Paris: Librairie Orientaliste Paul Geuthner.

1948. The Guarani. In Handbook of South American Indians, edited by J. Steward. Vol, 3: pp. 69-94. Washington, D.C.: Smithsonian Institution.

Métraux, A. and Baldus, H. 1948. The Guayaki. In Handbook of South American Indians, edited by J. Steward. Vol. 1: pp. 435-444, Washington, D.C.: Smithsonian Institution.

Miklouho-Maclay, N. de, 1885. List of Plants in Use by the Natives of the Maclay Coast, New Guinea. Proceedings, Linnean Society of New South Wales 10:346-358.

Miller, R, H. 1964. The Versatile Sugar Palm. Principes 8:115-147.

Misión de la Compañia de Jesús. 1900. El Archipiélago Filipino: Collección de Datos. 2 vols. Washington, D.C.: U.S. Government Printer.

Moore, H. E., Jr, 1973a. The Major Groups of Palms and Their Distribution. Gentes Herbarum 11:27-141.

1973b. Palms in the Tropical Forest Ecosystems of Africa and South America. In Tropical Forest Ecosystems in Africa and South America: A Comparative Review, edited by B. J. Meggers, E. S. Ayensu, and W. D. Duckworth, pp. 63-88. Washington, D.C.: Smithsonian Institution Press.

Morley, S. G. 1946. The Ancient Maya. Stanford, Calif.: Stanford University Press.

Morris, H. S. 1953. Report on a Melanau Sago Producing Community in Sarawak. Colonial Research Studies No. 9. London: Colonial Office. 1964. A Report on the Sago Industry on the Oya and Mukah Rivers. Mimeograph. London: Department of Social Anthropology, London School of Economics and Political Science, University of London. (Cited by Jackson, 1968.)

Netherlands East Indies. Various years. Departement van Economische Zaken. Jaaroverzicht van den in-en uitvoer van Nederlandsche-Indiè. Batavia: G. Kolff and Co.

. Various years. Dienst der In- en Uitvoerrechten en Accijnzen. Statistiek van den Handel. Batavia: G. Kolff and Co.

Nolan, H. W, 1942. Sago. Walkabout 8:10-12. 
Nooy-Palm, H. 1968. The Culture of the Pagai-Islands and Sipora, Mentawei. Tropical Man 1:152-241.

Nutz, W. 1959. Eine Kulturanalyse van Kei: Beitrage zur Vergleichenden Volkerkunde Ostindonesiens. Dússeldorf: M. Triltsch.

Oberg, K. 1953. Indian Tribes of Northern Mato Grosso, Brazil. Washington, D.C.: U.S. Government Printing Office.

Ohtsuka, R. 1975. The Sago Eaters: An Ecological Discussion with Special Reference to the Oriomo Plateau. Paper read at Sunda and Sahul Symposium, Pacific Science Congress, Vancouver, 1975.

Oijen, L. A. T. J. F. van. 1909. Sagoe en Sagoepalmen, Bulletin van het Koloniaal Museum te Haarlem 44:12-69.

Oliver, D. L. 1955. A Solomon Island Society. Cambridge, Mass.: Harvard University Press.

Oomen, H. A. P. C. 1971. Ecology of Human Nutrition in New Guinea: Evaluation of Subsistence Patterns. Ecology of Food and Nutrition 1:1-16.

Oomen, H. A. P. C. and Malcolm, S. H. 1958. Nutrition and the Papuan Child. South Pacific Commission Technical Paper 118. Noumea.

Oosterwal, G. 1961. People of the Tor. Assen: Royal Van Gorcum. 1967. Muremarew: A Dual Organized Village on the Mamberamo, West Irian. In Villages in Indonesia, edited by Koentjaraningrat. Ithaca, N.Y.: Cornell University Press.

Paijmans, K. 1975. Explanatory Notes to the Vegetation Map of Papua New Guinea. Land Research Series No. 35. Melbourne: Commonwealth Scientific and Industrial Research Organization.

Peters, F. E. 1957. Chemical Composition of South Pacific Foods-An Annotated Bibliography. South Pacific Commission Technical Paper 100. Noumea.

Pickering, C. 1879. Chronological History of Plants: Man's Record of His Own Existence Illustrated through Their Names, Uses, and Companionship. Boston: Little, Brown and Co.

Planche, M. 1837. Researches to Serve as a History of Sago-and an Examination of the Substance Called Sago of Cayenne, Obtained from the Sago Plant of Madagascar. American Journal of Pharmacy 9:214-225.

Polo, Marco. 1930. The Travels of Marco Polo. Edited by Komroff from Marsden's translation. New York: Liveright Publishing Corp.

Pouwer, J. 1955. Enkele Aspecten van de Mimika-Cultuur (Nederlands Zuidwest Nieuw Guinea). The Hague: Staatsdrukkerijen Uitgeversbedrijf.

Purchas, S. 1617. Purchas his Pilgrimes. London: Printed by W. Stansby for H, Fetherstone.

Republic of Indonesia. N.d.a. Ekspor menurut djenis barang, diperint ii menurut negeri tudjuan dan pelabuhan ekspor jang utama. Djakarta: Biro Pusat Statistik.

N.d.b. Penerbitan bulanan, Statistik perdagangan: Ekspor. (Title varies.) Djakarta: Biro Pusat Statistik.

Republic of Singapore. Various years. Singapore External Trade. Singapore: Department of Statistics. 
Reynders, J. J. 1962. Shifting Cultivation in the Star Mountains Area. Nova Guinea Anthropology 3:45-73.

Reynolds, J. P. 1972a. Bougainville District. In Encyclopaedia of Papua and New Guinea, edited by P. Ryan. Melbourne: Melbourne University Press in association with University of Papua and New Guinea.

1972b. New Ireland District. In Encyclopaedia of Papua and New Guinea, edited by P. Ryan. Melbourne: Melbourne University Press in association with University of Papua and New Guinea.

Riley, E. B. 1923. Sago-making on the Fly River. Man 23:145-146.

1925. Among Papuan Headhunters. Philadelphia: J. B. Lippincott Co.

Robequain, C. 1929. Le Thanh Hoa: Etude Géographique d'une Province Annamite. 2 vols. Paris and Brussels: G. van Oest.

Roth, H. L. 1896. The Natives of Sarawak and British North Borneo. London: Truslore and Hanson.

Roxburgh, W, 1874. Flora Indica: or, Descriptions of Indian Plants. 3rd ed. Calcutta: Thacker, Spink and Co.

Rumens, J. 1972. Gulf District. In Encyclopaedia of Papua and New Guinea, edited by P. Ryan. Melbourne: Melbourne University Press in association with University of Papua and New Guinea.

Schlesier, E. 1961. Zum Problem einer Sago-verwertenden Kulturschicht auf Neuguinea. Zeitschrift für Ethnologie 86:224-233.

1965. Sagogewinnung auf Normanby Island, Südost-Neuguinea. Baessler-Archiv 13:1-39.

Schmitz, C. A. 1960. Historische Probleme in Nordost-Neuguinea. Studien zur Kulturkunde 16. Wiesbaden: Franz Steiner Verlag.

Schuster, M. 1965. Mythen aus dem Sepik-Gebiet. Basler Beitrage zur Ethnologie 2 (Festschrift Alfred Buhler): 369-384.

Seemann, B. 1856. Popular History of the Palms and Their Allies. London: Lovell Reeve. 1865-1873. Flora Vitiensis. London: Lovell Reeve.

Seligman, C. G. 1910. The Melanesians of British New Guinea. Cambridge: Cambridge University Press.

Serpenti, L. M. 1965. Cultivators in the Swamps. Assen: Van Gorcum.

Siew, K. Y. 1973a. The Present Land Use of the Tawau Residency Sabah, 1970. Sabah Present Land Use Report No. 3. Kuala Lumpur: Division of Agriculture.

1973b. The Present Land Use of the Sandakan Residency Sabah, 1970. Sabah Present Land Use Report No. 4. Kuala Lumpur: Division of Agriculture.

Singh Uberoi, J. P. 1972. Kula. In Encyclopaedia of Papua and New Guinea, edited by P. Ryan. Melbourne: Melbourne University Press in association with University of Papua and New Guinea.

Smith, A. 1876a. Caryota. In The Treasury of Botany, edited by J. Lindley and T. Moore. 2 vols. 2 nd ed. London: Longmans, Green and Co. 1876b. Sagus. In The Treasury of Botany, edited by J. Lindley and T. Moore. 2 vols. 2nd ed. London: Longmans, Green and Co. 
Smith, F. P. 1911. Chinese Materia Medica. Shanghai: American Presbyterian Mission Press.

Speck, O. I. 1951. The Saksak Story, Walkabout 17:41-43.

Speiser, F, 1916. Völkerkundliches von den Santa-Cruz-Inseln. Ethnologica: Rauntenstrauch-Joest Museums für Völkenkunde, Koln. Leipzig: Hiersemann Verlag.

1946. Versuch einer Siedlungsgeschichte der Südsee. Denkschriften der Schweizerischen Naturforschenden Gesellschaft 77:1-81.

Spencer, J. E. 1961. The Migration of Rice from Mainland Southeast Asia into Indonesia. In Plants and the Migrations of Pacific Peoples, edited by J. Barrau, pp. 83-92. Honolulu: Bernice P. Bishop Museum Press.

Sprecher von Bernegg, A. 1929. Tropische und subtropische Weltwirtschaftspflantzen-ihre Geschikt, Kultur und Volkswirtschaftliche Bedeutung. Stuttgart: Ferdinand Enke.

Springhall, J. A., and Ross, E. 1965a. Preliminary Studies with Poultry Rations for the Territory of Papua and New Guinea: Grower Rations with Copra, Sago and Leucaena leucocephala. Papua and New Guinea Agricultural Journal 17:117-121.

1965b. Preliminary Studies with Poultry Rations for the Territory of Papua and New Guinea: Layer Rations with Copra, Sago and Leucaena leucocephala. Papua and New Guinea Agricultural Journal 17:122-126.

State of Brunei. Various years. Annual Report. Kuala Belait: Brunei Press.

State of Sabah. 1969. Department of Agriculture Annual Report. Kota Kinabalu: Government Printer.

State of Sarawak. N.d. Proposed Sago Planting Scheme. Mimeograph. Kuching: Department of Agriculture.

Steiner, M. L. 1961. A Dictionary of Vernacular Plant Names of Pacific Foodplants. Mimeograph. Manila: Pacific Science Association-National Research Council of the Philippines.

Streicher, J. F. 1934. Sagogewinnung: Aufsatz der Awanggom, aus dem Stamm der Hopoi, Neu-Guinea. Archiv für Anthropologie n.s. 23:236-237.

Sturtevant, W. C. 1969. History and Ethnography of Some West Indian Starches. In The Domestication and Exploitation of Plants and Animals, edited by P. J. Ucko, and G. W. Dimbleby, pp. 177-199. Chicago: Aldine.

Suárez, M. M. 1966. Les Utilisations du Palmier “Moriche" (Mauritia flexuosa) chez les Warao du Delta de l'Orenoque, Territoire Delta Amacuro, Vénézuela. Journal d'Agriculture Tropicale et de Botanique Appliquée 13:33-38.

1968. Los Warao. Caracas: Instituto Venezolano de Investigaciones Cientificas.

Tauern, O. D. 1918. Patasiwa und Patalima: Vom Molukkeneiland Ceran and seinen Bewohnern. Leipzig: R, Voigtlander.

Townsend, P. K. W. 1969. Subsistence and Social Organization in a New Guinea Society. Ph.D. dissertation. Ann Arbor: University Microfilms. 1974. Sago Production in a New Guinea Economy. Human Ecology 2:217-236. 
Townsend, P. K. W.; Liao, S-C.; and Konlande, J. E. 1973. Nutritive Contributions of Sago Ash Used as a Native Salt in Papua New Guinea. Ecology of Food and Nutrition 2:91-97.

Townsend, W. H. 1969. Stone and Steel Tool Use in a New Guinea Society, Ethnology 8:199-205.

Trimen, H. 1898. A Handbook of the Flora of Ceylon. 4 vols. London: Dulan and $\mathrm{Co}$.

Tupamahu, J. 1909. Sagoe en Sagoepalmen. Bulletin van het Koloniaal Museum te Haarlem 44:105-120.

Turrado Moreno, A, 1945. Etnografia de los Indios Guaraunos. Tercera Conferencia Interamericana de Agricultura, Cuadernos Verdes 15. Caracas: Litografía y Tipografía Vargas.

Vellard, J. 1939. Les Indiens Guayakis du Paraguay. Paris: Librairie Gallimard.

Wagley, C. 1953. Amazon Town. New York: Macmillan,

Wallace, A. R. 1885. The Malay Archipelago. New York: Harper and Bros.

Watson, J. B. 1952. Cayua Culture Change: A Study of Acculturation and Methodology. American Anthropologist 54, American Anthropological Association Memoir No. 73.

Watt, G. 1883. Economic Products of India, Part VI. Foods, Food Stuffs, and Fodders. Calcutta: Superintendent of Government Printing. 1908. The Commercial Products of India. London: John Murray.

West Malaysia. 1968. External Trade 1968; Vol. 1, Exports and Re-exports. Kuala Lumpur: Department of Statistics.

Wester, P. J. 1924. The Food Plants of the Philippines. Bureau of Agriculture and Natural Resources Bulletin 39. Manila.

Wheatley, J. G. G. 1894. Sago Cultivation in North Borneo. Kew Bulletin of Miscellaneous Information, pp. 414-417.

Whiting, J. W. M. and Reed, S. W. 1938. Kwoma Culture. Oceania 9:170-216.

Wilbert, J. 1972. Survivors of Eldorado. New York: Praeger Publishing Co.

1976. Manicaria Saccifera and Its Cultural Significance among the Warao Indians of Venezuela. Botanical Museum Leaflets 24:275-335. Cambridge: Harvard University.

Williams, F. E. 1930. Orokaiva Society. London: Oxford University Press. 1936. Papuans of the Trans-Fly. Oxford: The Clarendon Press.

1940. Drama of Orokolo; the Social and Ceremonial Life of the Elema. Oxford: The Clarendon Press.

Wio, L., trans. N.d. Sago and Rice: A singsing from Dagua. In Sago and Rice: An Anthology of Poems Written by Students of Brandi High School, Wewak. Multilith. Wewak, New Guinea.

Wirz, P. 1922-1925. Die Marind-anim von Holländisch-Süd-Neu-Guinea. 4 vols. Hamburg: L. Friederichsen and Co.

Wollaston, A. F. R. 1912. Pygmies and Papuans. London: John Murray.

Wong, I. F, T. 1973a. The Present Land Use of the Interior Residency Sabah, 1970. Sabah Present Land Use Report No. 1. Kuala Lumpur: Division of Agriculture. 
1973b. The Present Land Use of West Coast Residency Sabah, 1970. Sabah Present Land Use Report No. 2. Kuala Lumpur: Division of Agriculture.

1973c. The Present Land Use of Sabah, 1970. Sabah Present Land Use Report No. 5. Kuala Lumpur: Division of Agriculture.

Yen, D. E. 1974. Arboriculture in the Subsistence of Santa Cruz, Solomon Islands. Economic Botany 28:247-284. 


\section{INDEX}

Abelam, 43, 64; sago myth, origin of, 75-76

Acrocomia, 9, 50

Admiralty Islands, 47

African oil palm, 3-4. See also Elaeis

Alfendio, 22

Alfur, 43, 84

Allang, 48

Amazon Valley, 50, 66

Amboina, 89

Ambonese, 43, 60

Ambon Island, 18, 48

Annatto, 125

Arapesh, 22, 40, 92. See also Mountain Arapesh

Areca, 4, 61, 67. See also Betel nut

A recastrum, 4, 7, 20, 40, 43, 67, 85, 189 ; botanical description of, 9 ; edible fruit of, 38; geographic distribution of, 9; palm heart of, 38. See also Pindo palm

Arenga, 3, 4, 5, 15, 16, 19, 40, 43, 45, $50,61,64,66,67,69,71,85,188$, 190; botanical description of, 5; geographic distribution of, 7; palm heart of, 38; palm sap of, 38. See also Sugar palm

Aroids, 184

Aru Islands, 17, 48

Asangumot, 77, 80

Asmat, 15, 40, 43, 84, 93

Australia, 7, 136
Babar Island, 48

Bahrein, 157

Bali, 48, 156

Bamboo, 17, 18, 19, 20, 30, 50, 75, 77 , 80,102 ; cooking sago, used for, 36-37

Bananas, 37, 72, 75, 77, 81, 125

Bangka and Billiton islands, 48

Bangladesh, 157

Betel nut, 72, 76. See also Areca

Bila-an, 19, 22, 43, 50, 66

Bisaya, $43,49,67$; sago production of, 103-112

Borassus, 9

Borneo, 80, 185

Bororó, 38, 43

Bougainville Island, 47, 68

Brazil, 20, 41, 50, 66, 67

Breadfruit, 68

Brunei, 49, 96, 144, 154, 156, 157, commercial sago production in, 115-116

Buritt fruit, 38, 41. See also Mauritia

Burma, 157

Buru Island, 48

Busama, 93

Canary Islands, 9

Carex, 20

Caribbean, 9

Carnauba wax palm, 4. See also Copernicia 
Caryota, 4, 5, 15, 40, 45, 50, 66, 67, 68; botanical description of, 7; geographic distribution of, 7; palm heart of, 38; palm sap of, 38; sago yield of, 62

Cassava, 48, 49, 89, 93, 125. See also

Manioc; Tapioca

Chickens, 40, 106, 129. See also Poultry

China, 50, 66, 136, 144, 156, 157; sago trade of, 130

Chinese, $49,66,67,96,112,115,116$, $118,119,120,121,123,126,131$

Citrus, 38

Coconut, 3, 19, 22, 29, 59, 71, 74, 75, $87,88,89$; milk, 37

Cocos nucifera, 3. See also Coconut

Cocoyam, 125

Copernicia, 4, 67

Copra, 41

Cornstarch, 117, 128

Corypha, 4, 5, 43, 45, 50, 66, 68, 69; botanical description of, 7; geographic distribution of, $?$

Cotton, 133

Cycads, 5, 184, 189

Damar Island, 48

Daribi, 60

Date palm, 3. See also Phoenix

Dobu, 19

Dolak Island, 27, 89

Dyak, 24, 43, 67, 185

Elaeis guineensis, 4. See also African oil palm

Elema, 43, 47

Etoro, 94

Eugeissona, 4, 5, 44, 81, 188; botanical description of, 7; geographic distribution of, 7

Ficus, 38

Fiji, 42, 47, 189

Fly River, 16, 17, 22, 47, 74, 76, 85, 87

Foe, 43. See also Kutubu

Foraba, 60

Gadio Enga, 40, 43, 93

Garcinia, 38

Geelvinck Bay, 41

Ginger, 16, 73

Guaraní, 20, 38, 67. See also Kaingáng

Guayaki, 19, 20, 40-4I, 43, 58, 85

Hakka, 66

Halmahera, 19, 48, 61, 67
Hanunóo, 43, 67

Hiowe, 43. See also Sanio-Hiowe

Hong Kong, 66, 130, 136; sago trade of, 154

Hopoi, 19, 27, 43

India, $5,7,9,10,50,66,67,96,133$

Indonesia, 5, 7, 20, 22, 24, 42, 47, 48, $61,67,84,93,95,96,128,133,154$, $156,157,185,187$; sago trade of, 136,144

Irian Jaya, 15, 17, 18, 21, 27, 40, 42, $48,59,60,61,67,72,74,75,83,84$, $89,90,92,93,94$

Japan, 96, 116, 117, 123, 133, 136, 144,154

Jaya, 48, 185, 188, 190

Kadazen, 49

Kai Islands, 17, 48

Kaingáng, 43. See also Guaraní

Kajan, 80

Kalimantan, 7, 48, 185

Kaowerawedj, 17, 83, 93

Keraki, 22, 44; sago myth, origin of, 76-77

Keram River, 40

Kimam, 22, 27, 44, 89, 90

Kisar Island, 48

Kiwai, $21,22,44,85,187$; sagorelated rituals of, 87-89

Kiwai Island, 17

Korovagi, 59

Korowori River, 16, 17, 21, 58, 79

Kutubu, 16, 19. See also Foe

Kwoma, 44, 64, 93

Labuan Island, 96, 112

Limbum palm, 24, 75, 76

Lingga Islands, $48,144,156$

Lombok, 48, 156

Lumi, 58, 59, 60

Mailu, 37, 44

Mailu Island, 19, 37

Maize, 2, 36, 48, 106, 129

Malagasy Republic, 50, 66

Malaita, 68

Malaysia, 5, 42, 48, 95, 96, 128, 129 , $130,131,136$

Maldive Islands, 66

Maluku, 17, 21, 22, 48, 60, 67

Mambare River, 47

Mangrove, 47

Manicaria, 10, 41, 45, 86; edible fruit of, 38 ; origin myth of, $78-79$; starch, 
extraction of, 12; starch, nutritive value of, 57 ; starch, yield of, 62

Manioc, 5, 38, 96, 128, 129, 189. See also Cassava; Tapioca

Mappi River, 92

Maranta dichotoma, 15

Marind-anim, 21, 22, 44, 60, 93; sago myth, origin of, 76

Mauritia, 3, 4, 41, 45, 50, 66, 80, 85 , $86,185,188,190$; botanical description of, 9; edible fruit of, 38; geographic distribution of, 7, 9; starch, extraction of, 11-12; starch, yield of, 62

Mejbrat, 42, 44, 74, 92

Melanau, 13, 18, 24, 40, 44, 49, 64, $67,80,81,93,116,126$; pearl sago, production of, 28-36; sago, cultivation of, 117-121; starch, processing of, $117-121$

Mentawai Islands, 40, 48

Merauke, 47

Metroxylon, 3, 4, 13, 15, 16, 19, 20, $21,24,40,41,42,43-45,47,48,49$, $50,61,66,67,68,69,71,81,85,87$, $89,95,102,106,117,118,123,128$, $185,186,188,189$; botanical description of, 5; geographic distribution of, 5 ; palm heart of, 38-39; starch, nutritive value of, 57 ; starch, yield of, $62-63,64$

Me'udana, 44, 93

Millet, 48

Mimika, 15, 21, 44, 90, 93, 94

Mindanao, 22, 50, 66, 68

Mindoro, 67

Moluccans, 13

Montagnards, 66

Moriche palm, 11, 12, 80, 85, 86. See also Mauritia

Mountain Arapesh, 44, 74. See also Arapesh

Nambicuara, 41

Netherlands, 136, 144, 154

New Britain Island, 47

New Guinea, 22, 24, 40, 41, 47, 58, 60, $74,80,81,82,83,185$

New Hanover Island, 47

New Ireland Island, 47, 68

Nipa palm, 47, 102

Normanby Island, $15,77,92$

Nuaulu, 44, 94

Opi River, 47

Orinoco Delta, 9, 10, 11, 41, 42, 50, $80,85,185,190$
Orokaiva, 21, 22, 27, 44

Pakistan, 154, 157

Palau, 42

Palm: general uses of, 3 ; hearts, 38 , $39,85,105$; sap, 38 ; wine, $5,7,38,89$

Pandanus, 19, 29, 110, 119

Papua New Guinea, 5, 7, 15, 16, 17, $18,19,21,27,39,41,42,47,58,59$, $60,61,64,67,68,72,74,75,76,77$, $84,85,93,94,128,129$

Paraguay, 19, 20, 40, 58, 67, 85

Pearl sago, 95, 133, 136, 144; international trade in, 157; production of, $27-36,66,67$

Philippines, $7,15,18,19,24,42,64$, $67,68,83,136$

Phoenix, 3, 67; geographic distribution of, 9-10

Pholidocarpus, 9

Pigs, 39, 40, 49, 60, 73, 76, 88, 89, 91, $115,116,118,129$

Pindó palm, 20, 40, 85. See also Arecastrum

Pineapple, 125

Pork, 37, 59, 90

Port Moresby, 41

Potatoes, 2, 66

Poultry, 39, 116. See also Chickens

Punan, 44, 49

Purari Delta, 41, 47, 59

Queen palm, 9. See also Arecastrum

Raphia, 50, 66

Rattan, 22

Rice, $28,48,49,57,60,67,68,80,85$, $93,102,106,120,121,123,185,186$, 187; bran, 29-30, 96

Roma Island, 48

Rotuma Island, 42

Roystonea, 4, 7, 50; botanical description of, 9; geographic distribution of, 9

Rubber, 49, 96, 102, 133, 186, 190

Sabah, 48, 49, 67, 136, 144, 154, 156, $157,186,187$; commercial sago production in, 96, 102-115

Sago, 3, 5; complementary food use of, 66-67; cooking of, 36-38; digestibility of, 60-61; emergency food use of, 67-69; feed use of, 103; flour and meal, international trade of, 144, 154 ; medicinal use of, $66-67$; miscellaneous uses of, 1,2 ; modern industrialization and, 126-129; nutritive 
value of, 57-60; origin myths of, 7081; palm, cultivation of, $125-126$; palm, secondary food products from, $38-41$; preparation of, $13-24$; retailing of, 112-115; ritual role of, 83-92; sexual division of labor in processing of, $75,78,90-94,118$; storage of, 27 , 114 ; subsistence food use of, 42, 4750, 57-61; swamp, development of, 123-126; symbolism of, 90-94; traditional trade in, 41; yields of, 61-64. See also Pearl sago; Sago biscuit; Sago grubs; Sago pith; Sago refuse; Wet sago

Sago biscuit, $31,95,96$

Sago grubs, $60,72,189$; food use of, $38-41$; nutritive value of, 58-59

Sago pith, 20, 80, 85, 95, 133, 144; feed use of, 39; international trade in, 156-157

Sago refuse, 95, 96, 129, 144; feed use of, 115; international trade in, 156

Sakr palm, 74

Salt ash, 39

Samarokena, 75, 93

Samoa, 42

Sanio-Hiowe, $21,22,27,37,39,58$, $60,61,64,84,85,93,190$; sago myth, origin of, $72-74$

Santa Cruz Islands, 47

Sarawak, $7,18,24,40,48,49,64,67$, $80,81,93,95,107,128,129,131$, $133,136,156,185,186,187,188$, 189; commercial sago production in, 116-123; pearl sago production in, 27-36; sago swamp development in, 123-126; sago trade of, 144,154 , 156,157

Sepik Gulf, 47

Sepik River, 15, 16, 19, 40, 47, 61, 64, $77,81,82,83$

Seram, $19,22,48,64,84,94$; sago myths in, 71-72

Silaun Gramma, 103

Singapore, $95,96,116,120,128,130$, $131,133,136,144,190$; sago trade of, $144,154,156,157$

Siuai, 45,93

Solomon Islands, 18, 47, 68

Sorghum, 2

Spain, 154

Sri Lanka, 7, 10, 50, 157

Starch industry, development of, 2-3

Subanu, 45,68

Subsistence systems, productivity compared of, 64-65

Sugar, 2, 5, 7, 38

\section{Sugarcane, 77}

Sugar palm, 71. See also Arenga

Sulawesi, $15,16,22,36,48,61,67,80$, 84,85

Sulu Island, 48

Sumatra, 48, 136, 144, 156

Sweet potatoes, 2, 77, 81

Syagrus, 50, 66, 189

Taiwan, 9, 154

Talipot palm, 7. See also Caryota

Tangu, 45, 92

Tanimbar, 19, 20, 45, 67, 84

Tapioca, 130. See also Cassava; Manioc

Taro, 20, 37, 68, 77, 81, 89, 184, 185, 190

Tasaday, $15,19,39,40,45,50,83$

Temiche palm, 12, 86; origin myth of, 78-79; starch, nutritive value of, 57

Thailand, $5,42,49,128,129,136$, $144,156,157$; sago trade of, 130

Tikopia, 19, 20, 22, 24, 27, 45, 67, 68, 93

Timor, 20

Tobacco, 72, 74, 89

Tonga, 42

Tor, $45,83,93$; sago symbolism of, 90-92

Toradja, 15, 16, 19, 22, 45, 61, 67, 76, $80,84,85$; sago cooking, methods of, 36-37; sago myth, origin of, 70-71

Tulip tree (Gnetum gnemon), 58, 59

Tundawe, 60

Turama River, 47

United Kingdom, 117, 133, 144, 154, 157

United States, 142

Vietnam, 66

Warao, 10, 11, 27, 41, 45, 50, 80, 85, $86,89,93,187,190$; sago myth, origin of, 78-79; sago, preparation of, $11-12$

Waropen, $17,41,45,47,59,60,89$, 92; sago myth, origin of, 72

Water buffalo, 106

West Indies, 50, 189

West Malaysia, 7, 42, 96, 130, 131, $133,136,144,157,189$; sago trade of, $154,156,157$

Wetar Island, 48 
Wet sago, 29, 95, 118, 119, 126; feed use of, 116 Wheat, 2, 186

Wogamus River, 16, 58

Wogeo, 17, 19, 27, 45, 93
Yams, 4, 7, 50, 68, 76, 77, 81, 85, 89, $125,184,185$

Yimar, 21, 22, 45, 58; sago myth, origin of, 79-80

Yuat River, 40, 80, 81 


\section{出 PRODUCTION NOTES}

This book was designed by Roger J. Eggers. Composition was done on the Unified Composing System by the design and production staff of The University Press of Hawaii.

The text and display typeface is English Times.

Offset presswork and binding were done by Thomson-Shore, Inc. Text paper is Glatfelter P \& S Offset, basis 55 . 


\section{Paddy Soils in Tropical Asia}

Their Material Nature and Fertility

Keizaburo Kawaguchi and Kazutake Kyuma

Two world-renowned research scholars have collaborated to write this book, a study of paddy soils in the broad area of tropical monsoon Asia, which includes Southeast Asia and the Indian subcontinent. The authors discuss in detail the historical importance of rice cultivation, in terms of climate and physiography, in this region of the world. Edaphology and chemical composition of the soils are treated both as a whole and by individual country. Soil fertility is numerically assessed by a unique system that uses principal component analysis and factor analysis; and special problems, such as silting, nutrient deficiencies, toxicity, and salinity, are discussed. Often, the U.S. Soils Classification System and the "local Asian" classification or name are given. The future of rice agriculture is looked at in terms of intensification and diversification and the kinds of soils left for future development.

This book will be a valuable research aid and tool for soil scientists, agricultural technologists, and agronomists, in both the West and Asia.

\section{Monographs of the Center for Southeast}

Asian Studies, Kyoto University

ISBN 0-8248-0570-4, cloth, $\$ 15.00$

ISBN 0-8248-0571-2, paper, $\$ 10.00$

1977
Some Tropical South Pacific Island Foods

\section{Description, History,} Use, Composition, and Nutritive Value

Mary Murai, Florence Pen, and Carey D. Miller

"Of interest to historians, to geographers, to botanists, to anthropologists, to agriculturists, as well as to home economists."

\section{Journal of Home Economics}

ISBN 0-87022-550-2

1958 , paper, $\$ 3.50$

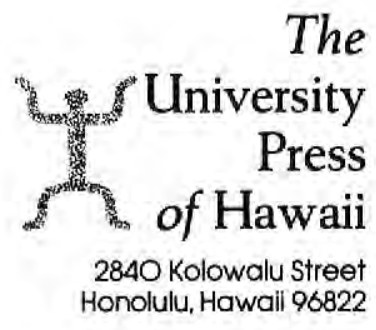




\section{PALM SAGO}

\section{A Tropical Starch from Marginal Lands}

by Kenneth Ruddle, Dennis Johnson, Patricia K. Townsend, John D. Rees

This book takes a multidisciplinary and multicultural approach to studying the relationship between human societies and foodyielding tropical palms. A joint effort of four people whose specialties complement each other, it provides a broad and thorough examination of palm sago, a starch that has potential for small-scale, low-cost development in marginal areas of the tropics. Information on the extraction and production of palm sago in insular and mainland Southeast Asia, the tropical Americas, Melanesia, South China, and South Asia is presented here.

More than an ethnobotanical monograph, this study places palm sago and its use within the relevant historical, technological, nutritional, commercial, and ritual context. Well-illustrated and drawing together a broad spectrum of information, this study provides the depth of knowledge of man/plant relationship needed to plan the rational development of tropical swamp environments. Academics and professionals in many fields will find this book of interest.

KENNETH RUDDLE has published widely on various aspects of natural resource use in Asia and Latin America. He is currently a research associate at the Technology and Development Institute of the East-West Center and research associate in ethnology at the Los Angeles Museum of Natural History.

DENNIS JOHNSON is assistant professor of geography at the University of Houston. His specialty is tropical agriculture and plant geography.

PATRICIA K. TOWNSEND is adjunct assistant professor of anthropology at SUNY/Buffalo. She has done ethnographic field research in a sago-using community in Papua New Guinea.

JOHN D. REES is assistant professor of geography at California State University, Los Angeles. He has conducted research in ethnobotany in Mexico and Central America.

\section{玉 ANEAST-WEST CENTER BOOK}

The University Press of Hawaii

Honolulu, Hawail 96822 